Historic, Archive Document

Do not assume content reflects current scientific knowledge, policies, or practices. 



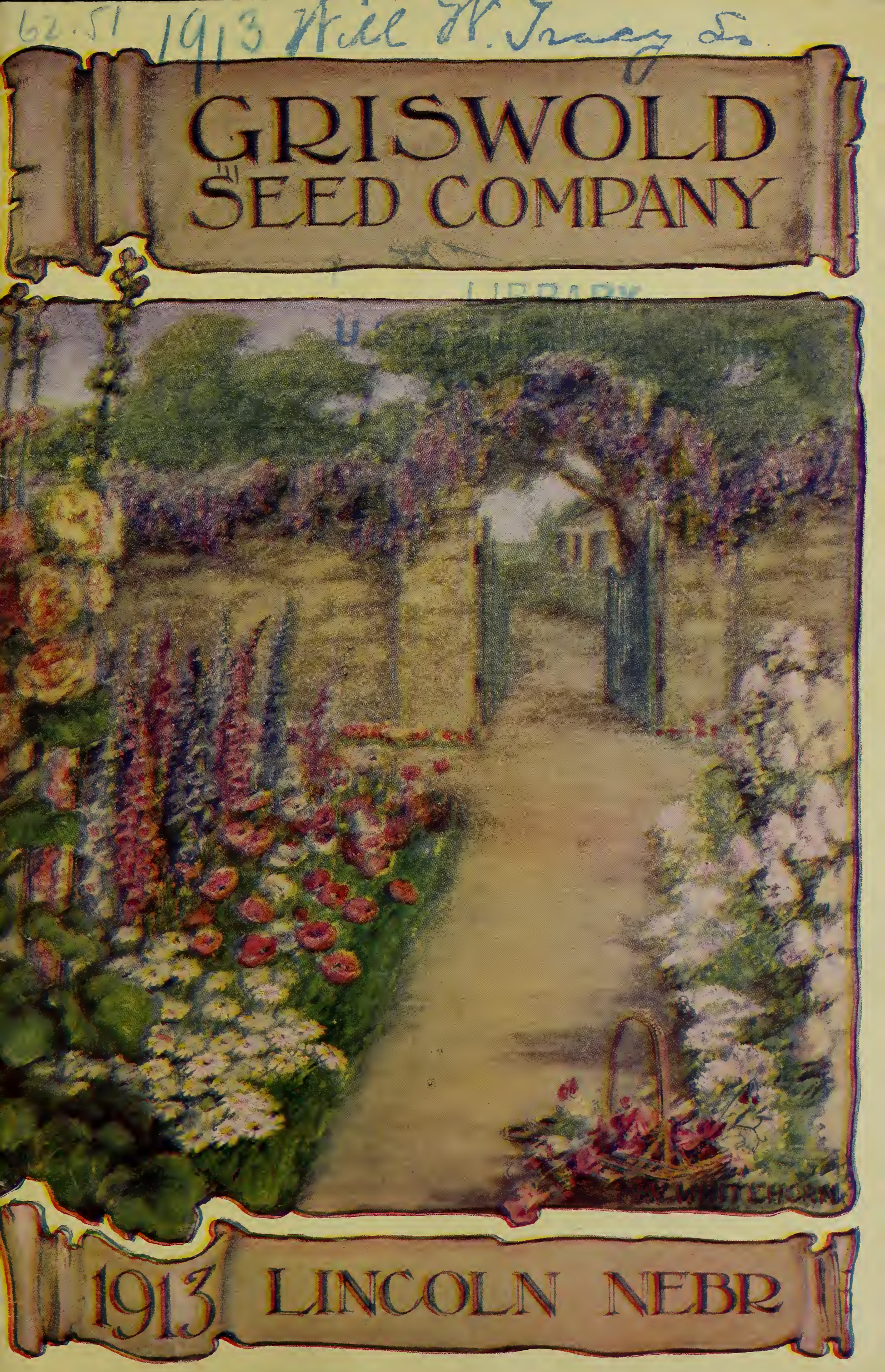




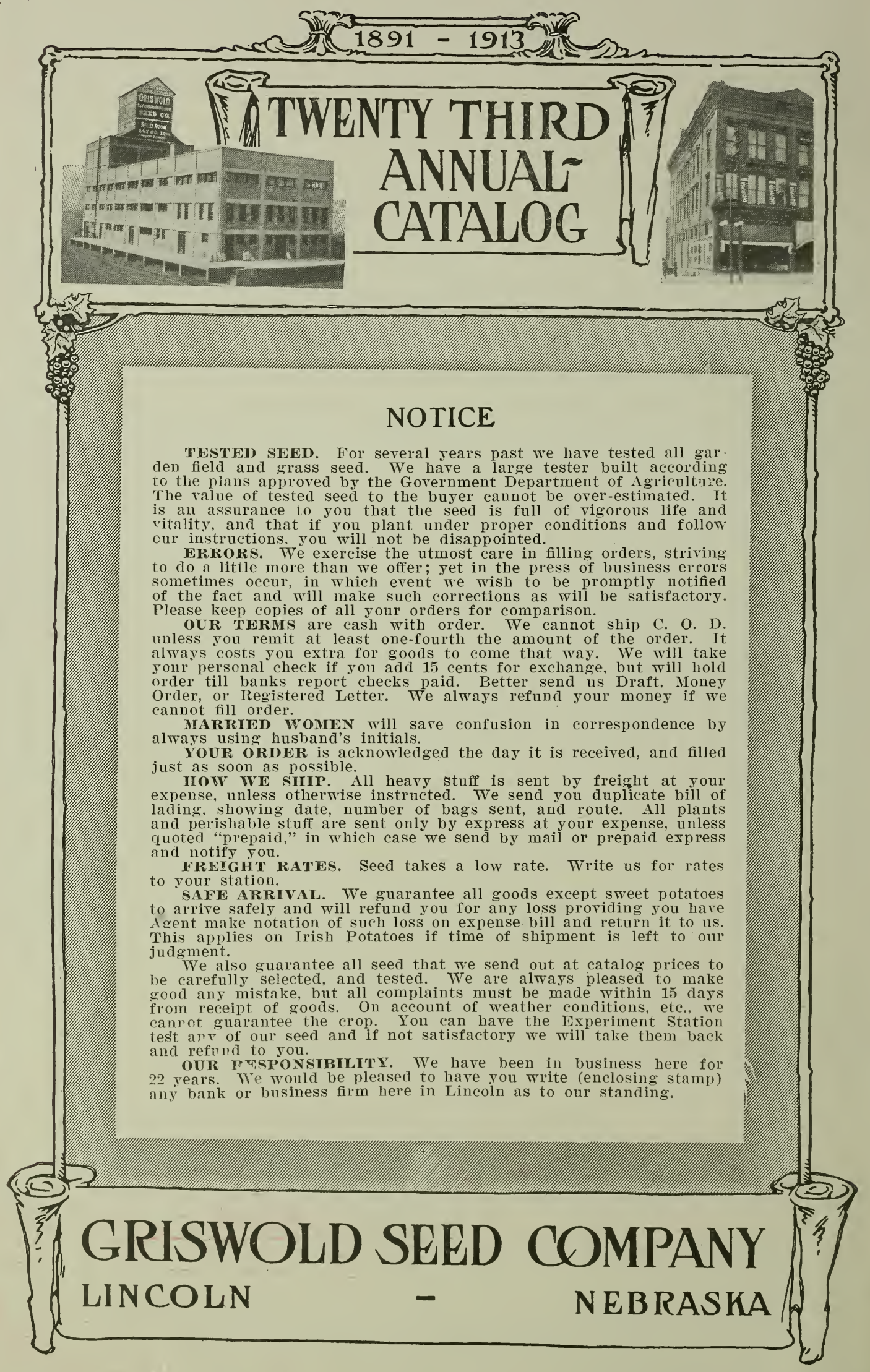



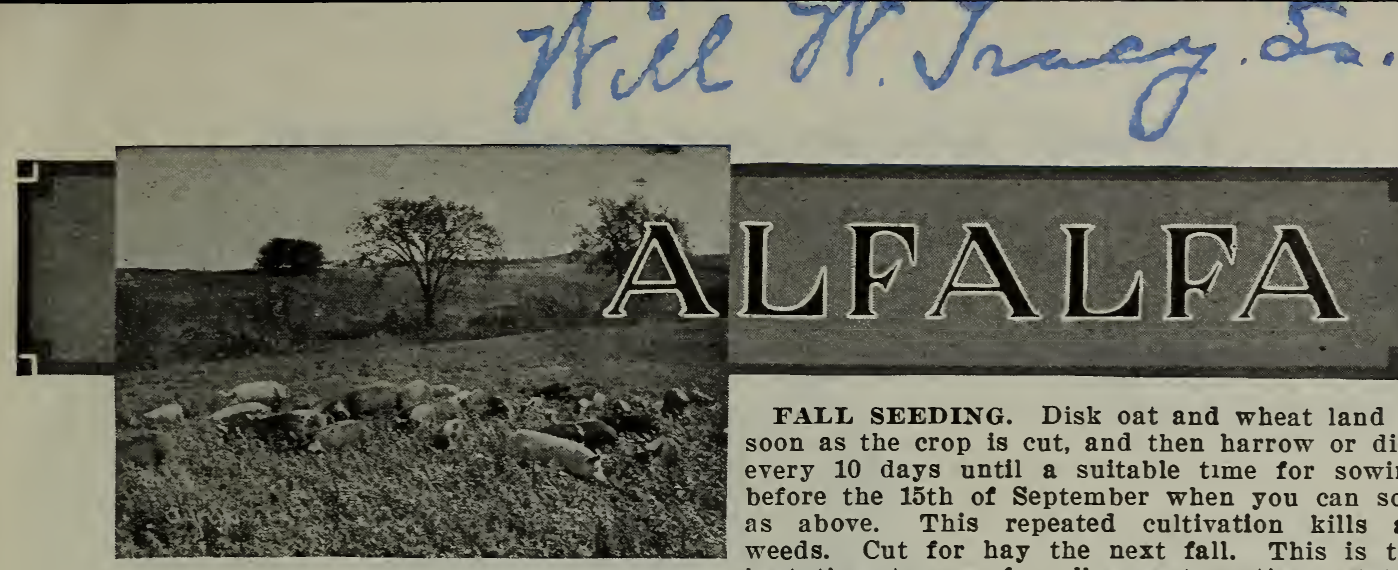

SUITABLE SOIL. Alfalfa makes a strong and rapid growth on well drained, rather heary lanrl, which is supplied with some lime, and where the subsoil, while not necessarily sand or gravel, is porous. On sandy soil the growth is vigorous, when moisture is abundant, but during drought it will suffer unless the roots reach water at a depth of 8 to 10 feet. The land should slope some, as alfalfa will not stand surface water.

SEED BED. The land must be free from weeds and the ground must be thoroughly pulverized and well packed. Alfalfa will frequently fail if seeded on freshly plowed ground. If it is necessary to plow the ground before seeding, do it early, harrow thoroughly and sow after a good rain has settled it.

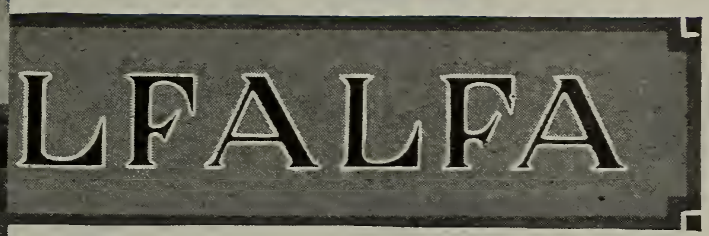

FALC SEEDING. Disk oat and wheat land as soon as the crop is cut, and then harrow or disk every 10 days until a suitable time for sowing before the 15th of September when you can sow as above. This repeated cultivation kills all weeds. Cut for hay the next fall. This is the best time to sow for all except northern states, if you are sure of getting full rains soon enough.

TURKESTAN ALFALFA. This is the same variety as the common alfalfa, but has been grown for years in the mountains of Turkestan, Asia, in a region where there is very small rainfall and with hot, dry summers, and dry, cold winters. A plant developed under such conditions could not be otherwise than nardy and strongly drouth-resistant, and such has proved to be the case.

ALFALFA IS A DEEP FEEDER. The tap roots descend to great depths wherever the soil is loose and permeable, often areraging 10 to 12 feet. It has been recorded as sending its roots to the depth of 50 feet.

SPRING SEEDING. Sow seed broadcast or with arill from March to June 15 , at the rate of 20 pounds to the acre.

\section{Our Government Tested Seeds?}

We are very particular with all our alfalfa seed and take no chances. We have every car of it tested by the U. S. Department of Agriculture. We will not sell alfalfa seed unless it is free from Trefoil, Sweet Clover, and Dodder. Seed is too high for you to take any chances. Buy our Fancy Seed from us and have it tested. We take it back if it doesn't test right. Buy it early for the price will be higher.

\section{PRICES}

FANCY SEED. Per lb., postpaid, 40c. By freight, per bu., 25c; 20 lbs. (for 1 acre), $\$ 3.75$; per bu. (60 ibs.), $\$ 10.50$.

TURKESTAN SEED. Per lb. postpaid, 40c. By freight, per lb., $25 \mathrm{c} ; 20$ lbs. (for 1 acre), $\$ 3.75$; per bu. (60 lbs.), $\$ 10.50$.

When you are ready to buy ask us for prices and give the gmount of seed you will need.

THESE PRICES GUARANTEED THL FEBR. 1ST ONLY.

Broadcast Seeders from $\$ 1.65$ up. See page 75 .

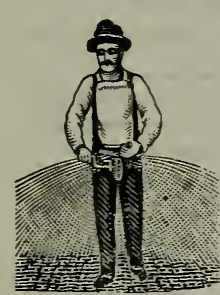

Lee Co., Iowa, Nov. 2, 1912.

The Sweet Clover did very nicely, making a growth of about 1 foot, which you know is very good on the first year. All kinds of stock are fond of Sweet Clover as a pasture and as hay, if cut at the proper time. As a soil builder it is the most valuable of plants.

Price $\$ 1.75$

\begin{tabular}{|c|}
\hline TO KILL GOPHERS \\
Use Gophergo. See page r1. $^{-}$
\end{tabular}

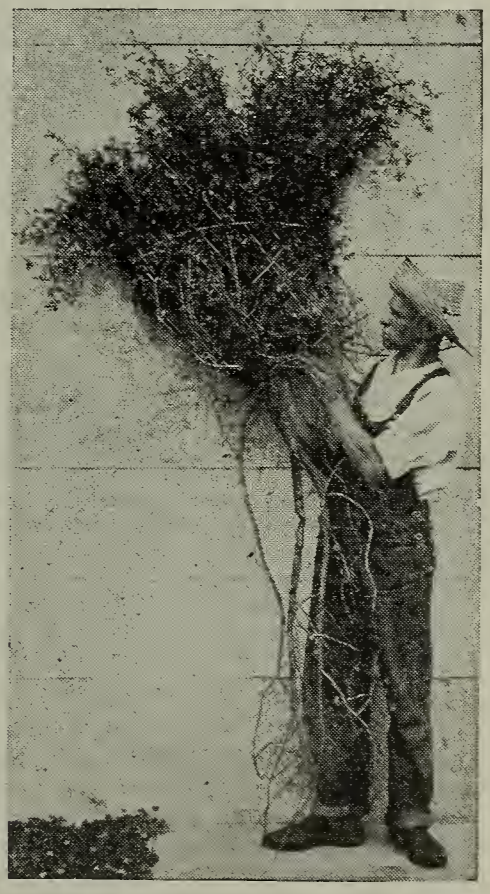
1,000 LBS. OF NITRATE PER ACRE PRODUCED BY

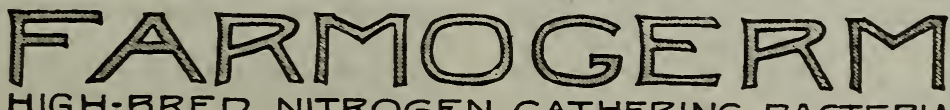

HIGH-BRED NITROGEN GATHERING BACTERIA

SEED AND SOIL INOCULATIONS.

GARDEN PEAS, BEANS AND SWEET PEAS

yield earlier, better and longer when they are ferring weed seeds, etc., throughout your farm. inoculated with Farmogerm. Farmogerm comes to you in bottles ready for use. You can inoculate the seed for ten acres in ten minutes. When you use Farmogerm there is no danger of trans

We strongly recommend these inoculations to all our customers.

For Alfulfa, Cow Peas, Soy Beans and Clover. 


\section{Sow 20 lbs. to Acre \\ TURNS SA N D I N T O \\ LOAM. FILLS THE \\ SOIL WITH NITRO- \\ GEN. IT WILL RE- \\ DEEM THE WESTERN \\ SAND HHLLS.}

\section{A VALUABLE PLANT}

This valuable forage plant, though once branded as a weed, is proving to be most valuable for our western semi-arid region. After two years the plant dies and the large roots decay, filling the soil with humus and vegetable fiber. This, in time, turns the sandy soll into a sandy loam which also has a tendency to make the soil more stable and less liable to blow.

This seed can be sown in the spring or in the fall at the rate of from 15 to $201 \mathrm{bs}$. per acre. It makes a large growth the first year and blooms and makes seed the second year and then dies. Many farmers in western Nebraska are now sowing their ground to Sweet Clover and the second year after cutting the crop, just before seeding, will sow it to Alfalfa. In this way they hold the soil from blowing and get their land seeded to Alfalfa.

\section{GOOD AS ALFALFA}

Many farmers claim that the forage from this plant is just as good as Alfalfa and just as readily eaten by the stock after they have become accustomed to it.

\section{TIME TO CUT}

If cut for hay, it should be cut when about two feet high and before the stem is woody. If cut just before the seed is matured, two years in succession, the plant dies out entirely.

\section{GOOD QUALITIES}

It will not grow in cultivated land nowwill it become a nuisance. It is most valuable for bees. Price, 35c per lb., postpaid. By freight, 25c per lb.; 5 lbs. for $\$ 1.10 ; 10$ lbs. for $\$ 2.00 ; \$ 10.00$ per bu.

Furnas Co., Nebr., 11-1-12.

I have had some experience with Sweet Clover in Saline Co., Nebr., and find that stock will eat it as well as Alfalfa hay when properly cured.

\section{Other Clovers}

W. H. SCHULTz.

Our Clover Seeds are of the Highest Grade and Thoroughly Cleaned and Tested

Every farmer should have some land sowed in clover. It is of the greatest value for plowing under for supplying humus and nitrogen.

MEDIUM RED, COMMON OR JUNE CLOVER. This is by far the most important of all the varieties for hay or pasture. Sow in Spring or Fall, and if no other grasses are used, at the rate of 8 to 12 pounds per acre. This clover is a bienial, and at best only lasts three years unless it is allowed to reseed itself, which should be done every two years. Fancy, per lb., 45c; postpaid. By freight, per 1b., 35c; per bu. (60. lbs), $\$ 13.50$.

\section{MAMMOTH RED, SAPLIN OR VINE CLOVER.}

Quite distinct from Common Red Clover. It lasts longer and is two or three weeks later than the Common Red Clover, grows from 3 to 5 feet high and yields an enormous amount to the acre, especially valuable for hog feed and for plowing under green or worn out lands. Sow $12 \mathrm{lbs}$. seed to acre. Per lb., 40c, postpaid. By freight, 30c per lb.; per bu. (60 lbs.), \$13.75.
WHITE DUTCH CLOVER. Best adapted to moist soils, but does well on any land. Sow 8 lbs. to acre. Per lb., 60c; postpaid. By freight, 1 lb., 50c; 5 lbs., $\$ 2.40 ; 10$ lbs., $\$ 4.70$.

ALSIKE OR SWEDISH CLOVER. One of the hardiest of all clovers. This clover is very nutritious, yields abundantly and can be cut several times during the season. It is good for pasture, green fodder or hay. The roots do not heave like those of Red Clover and for this reason it is especially adapted for wet, moist places. It does well on most any soll and resists the severest cold and extremes of drought and wet. We advise farmers to sow 2 or 3 pounds of this seed with their Red Clover and Timothy. If alone, sow $8 \mathrm{lbs}$. to the acre. Price per lb., 40c, postpaid. By freight, $30 \mathrm{c}$ per lb.; bu. (60 lbs.), \$14.50.

PRICES ON THIS PAGE SUBJECT TO CHANGE AND GUARANTEED ONLY THLL FEBR. $1,1913$. 


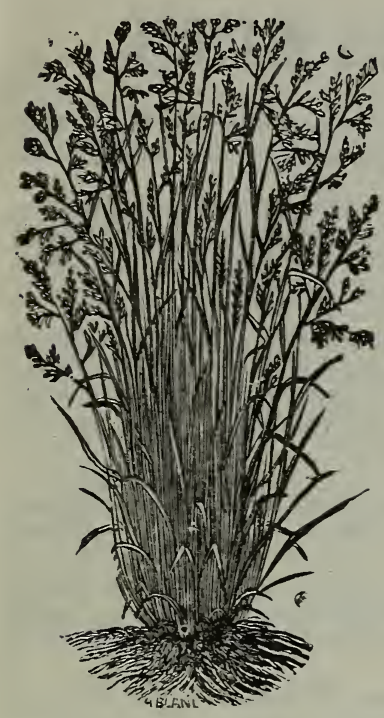

$11 / 2$ to 2 bu. per acri

\begin{tabular}{|c|c|}
$\begin{array}{c}\text { Sow } 21 \\
\text { to } 28 \text { lbs. } \\
\text { per acre. }\end{array}$ & Meadow Fescure \\
onglish Blue Grass & $\begin{array}{l}14 \text { lbs. to } \\
\text { bushel. }\end{array}$ \\
\hline
\end{tabular}

Hardy and very valuable for seed and pasture. Starts early in the spring and lasts until November and December. Just the grass for permanent pasture or meadow.

soIL. On moist or wettish soil (not too wet) and on gumbo land the plant flourishes wonderfully, jields the heaviest and holds on more tenaciously than anywhere else.

For Pasture. It grows luxuriantly, the blades being broad, tender and nutritious, and springs up quickly after cropping. It starts early in the spring, affording most excellent picking by march 20 or 30 , and in the fall will frequently keep cattle fat until late in November.

For Hay. Meadow Fescue should be cut soon after the blooms fall.

Seeding. Sow broadcast, 21 to 28 pounds of seed per acre on a well prepared bed, and harrow once lightly to cover the seed. Plant good, clean seed. The best seed is the cheapest to buy.

Cheat looks very much like Meadow Fescue. If you buy from us you are sure of getting the pure seed.

PRICES. By mail, 30c per lb. By freight, 20c per lb.; $\$ 2.00$ per bu. Write for prices on larger lots, stating amount you wish.

\section{Orchard Grass}

14 lbs. to the bu.

Because of its rapid growth orchard grass is one of the most valuable and popular of our domestic grasses. It is hardy and may be grown anywhere in the United States, except the extreme South and the arid regions of the West. It is a very hardy perennial, a vigorous grower and does as well in shade as in sunshine. It is about two weeks earlier than timothy and one of the last to succumb to frost in the fall.

Orchard Grass will stand repeated pasturing and mowing, makes from 2 to 6 tons of very nutritious hay. In many sections it may be grazed throughout the winter. It resists drouths remarkably well, and will succeed in any soll or climate where other grasses will grow.

The tendency of Orchard Grass to grow in tufts may be overcome by thorough preparation of the ground and liberal seeding or sowing with other grasses. It may be sown with good results at most any time from January to September, inclusive. Sow (if alone) $1 \frac{1}{2}$ to 2 bushels per acre. Price per lb., 35c, postpaid. By freight, per lb., 25c; per bu. (14 lbs.), \$2.75. Ask for prices in larger lots.

\section{FANCY CLEAN GRASS SEEDS FOR ALL SOILS}

CANADA BLUE GRAss. This is the blue grass of Canada, New York and the New England States. It does better on poor, clayey, thin soils than on rich land. It is smaller, grows closer to the ground and stands cold and drought better than Kentucky Blue Grass. Has a very blue color and flatish stems. Very nu. tritive and really a valuable grass. Not desirable for lawns. Per lb., 35c; postpaid. By freight, per lb., 25c; per bu. (14 lbs.), \$1.75.

KENTUCKY BLUE GRASS. This valuable grass is very productive, usually early and very desirable as a pasture grass. It comes in the spring and with a few rains during the summer will make good pasture until late fall. It is surprising how well this grass does in the West, even during the dry season. It is very desirable for lawns. Price, per lb., 35c; postpaid. By freight, per 1b., 25c; per bu. (14 lbs.), \$2.25.

RED TOP. Valuable either for mixing in hay or permanent pasture grass. Succeds almost everywhere but does best in moist, rich soil. It is being sown with Alsike in western Nebraska, with a great deal of satisfaction. It is often sown with Timothy and Clover. Price, fancy hulled, 35c per lb.; postpaid. By freight, per lb., 25c; per bu., \$3.25. Fancy unhulled, per lb., 25c; postpaid. By freight, per lb., 15c; per bu. (14 lbs.), \$1.65.

ENGLISH OR PERENNIAL RYE GRASS. This grass is considered invaluable for permanent pasture grass. Produces an abundance of remarkably fine foliage and soon forms a compact sod. After being cut it grows quickly and remains bright and green through the season. It is also a good variety for hay if cut when in blossom, as it is then most nutritious. Flourishes best in moist soil. Price, per 1b., 25c; postpaid. By freight, per lb., 15c; per bu. (24 lbs.), \$2.25.

TIMOTHY. This grass is used extensively for hay and does well on most any soil. Sometimes grows to the height of 4 feet on rich loam. It is exceedingly nutritious, particularly when ripe. This grass is also used for pasture. It is, however, better for hay and is sown mostly with Red Clover. Price, per 1b., 20c; postpaid. By freight, Fancy, per 1b., 10c; per bu. (45 lbs.), $\$ 2.75$.

JOHNSON GRASS. As a meadow or hay grass this variety is highly esteemed in the South and during the hottest and driest season it can be depended on to yield heavily. It is hard to get rid of when once started and for this reason it should not be allowed to get started in cultivated lands Price, per lb., 35c; postpaid. By freight, per 1b., 25c. Ask for price by $100 \mathrm{lbs}$.

PRICES ON THIS PAGE ARE GUARANTEED ONIY UNTE FEBR. 1ST, 1913. 


\section{GRISWOLD'S "READY QUICK" HOG PASTURE MIXTURE}

\section{GOOD FOR ONE SEASON ONLT}

The last two or three years, and especially the last year, we have had a big demand for a Hog Pasture Mixture that would not only produce a large tonnage of green feed but one that would come on quick and be ready in a hurry.

To fll this demand we have made our "Ready Quick" Hog Pasture Mixture. It is especially good

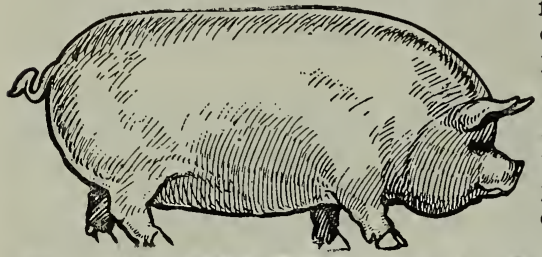

16 TONS GREEN FEHD PER ACRE for hogs but equally desirable for cattle, sheep, calves and cows. It contains 14 different grains and forage plant seeds, practically all of which grow again if fed down.

Griswold's "Ready Quick" Hog Pasture Mixture can be sown early and be ready to pasture in 6 or 8 weeks and should be in the finest kind of condition in July or August, just when your other pastures are dried up. It can also be sown in July or August and used as a fall pasture. per acre during the season, and to have this come just as a time when you have nothing else to feed Jour stock will be highly appreciated.

We recommend sowing $50 \mathrm{lbs}$. to the acre, and if your ground is very rich and strong we would may sow 75 to $100 \mathrm{lbs}$. and by all means keepit fed down, as the stock eat it better when it is young and tender. Be sure and give this valuable Mixture at least a small trial as you cannot possibly make any mistake by sowing it.

$50 \mathrm{lbs}$. (for one acre), $\$ 2.25 ; 100 \mathrm{lbs}$., $\$ 4.00 ; 500 \mathrm{lb}$. lots or over, $\$ 3.85$ per $100 \mathrm{lbs}$. In less than 50 lb. lots., 5c per Ib., or 15c per lb., postpaid.

Davies Co., Mo., Nov. 2, 1912.

Would say your Ready Quick Hog Pasture Mixture was really a surprise to me. It was a sight to see. It made an immense amount of pasture. I consider it a flne mixture for hogs and calves.

S. G. MOONEY.

Sow 20 lbs. per acre.

Grows in Dry, Semi-Arid Regions. Very Resistant to Drought and Freezing. Legnthens Season of

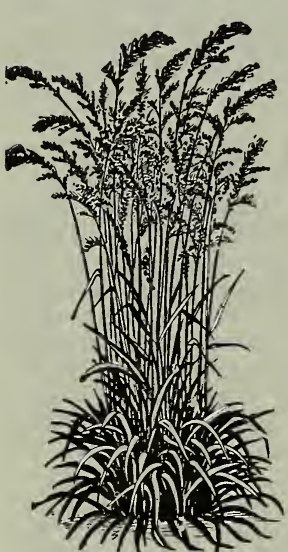

Nebraska Experiment Station says: This is one of the principal grasses grown in the dry and semi-arid regions of Russia and Siberia. It starts very early in the spring, and continues growth until late in the fall. Brome grass spreads by means of underground rootstalks. As a hay crop, the grass usually furnishes $\mathrm{g}$ o od cuttings for two or three years, sometimes cutting three tons of cured hay per acre, after which the sod becomes so rootbound that the grass does not grow tall enough for hay (this can be overcome by disking) but will furnish the best of pasture for several years.
PREPARATION OF LAND. The soll should always be in fine tilth and well packed. For spring sowing, a piece of fall plowing is most easily prepared and furnishes an almost ideal seed bed. If the land is plowed just preceding the sowing, it should be thoroughly worked down with disk and smoothing harrow until a fine, firm seed bed is made.

SOWING THE SEED. Sow early at least 20 pounds of seed alone broadcast per acre, or better disc in. Cover the seed by harrowing twice with smothing harrow. Do not be discouraged in case you should get a thin stand as the grass will thicken rapidly after the first season.

FALL SOWING. Sow 20 lbs. to the acre before September 15th, disk in on wheat or oat stubble: in this way one gets almost full use of the grass next year.

Prices. Fancy Grade or Pure Seed. Per lb., 35c; 5 lbs., $\$ 1.40$; postpaid. By freight, per lb., $25 \mathrm{c}$; per bu. (14 lbs.), $\$ 2.50$; 5 bu. lots, per bu., $\$ 2.45 ; 100$ lb. lots, per 100 lbs., \$16.75.

Write for prices on larger lots.

\section{GRASS MIXTURES}

MIXTURE FOR HOG PASTURE. This will be considered very heavy seeding and expensive, but if you have a hog pasture for keeps, you cannot afford to skimp on seed or limit the varieties. Alfalfa, Mammoth Clover, Red Clover, Alsike Clover, White Clover, Timothy, Blue Grass, Orchard Grass, Meadow Fescue. 25 lbs., per acre for $\$ 4.25$; per $100 \mathrm{lbs}$., $\$ 16.00$. Write for prices in larger lots.

UNIVERSITY GRASS MIXTURE. This is a special mixture recommended by the University Experiment Station as the best for pasture. We mix it in the right proportion and use only the very best grade of seed. Brome Grass, Meadow Fescue, Orchard Grass, Alfalfa. 24 lbs. per acre, $\$ 4.20$; per $100 \mathrm{lbs}$., $\$ 16.50$.

MIXTURE FOR HIGH LAND. Good for pasture and hay. Brome Grass, Meadow Fescue, Orchard Grass, Timothy, Alfalfa and Red Clover mixed in proper proportions. $20 \mathrm{lbs}$. per acre, $\$ 3.25$; per 100 lbs., $\$ 15.00$.

MIXTURE FOR LOW, DAMP SOIL. Can be cut for hay but better for pasture. Kentucky Blue. Grass, Red Top, Meadow Fescue, Alsike Clover, English Rye Grass and Timothy. 20 lbs. per acre, $\$ 2.30$; per 100 lbs., $\$ 11.00$. 

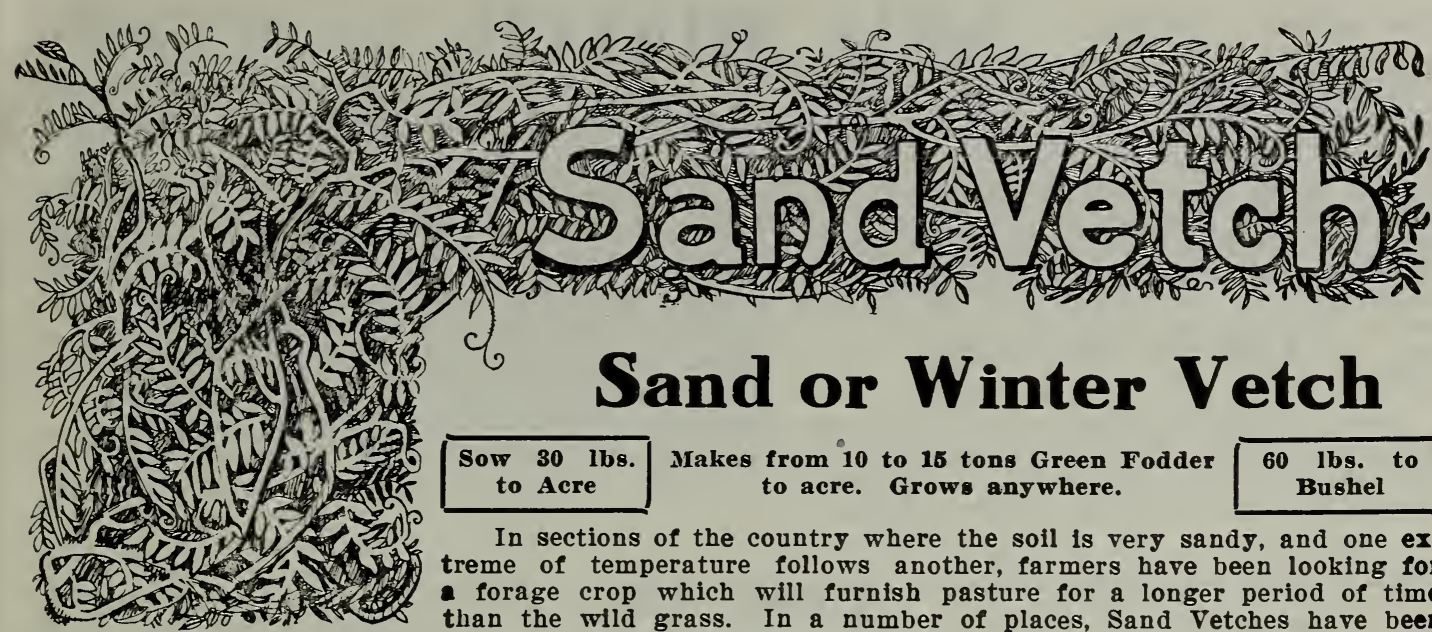

Sow 30 lbs. Makes from 10 to 15 tons Green Fodder to Acre to acre. Grows anywhere.

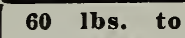

In sections of the country where the soil is very sandy, and one extreme of temperature follows another, farmers have been looking for a forage crop which will furnish pasture for a longer period of time than the wild grass. In a number of places, Sand Vetches have been tried with good success.

The plant somewhat resembles a pea vine. The long, slender stems are thickly covered with leaves which make nice succulent feed.

TIME To sow. When sown in August or September, Sand Vetch will cover the ground before Winter and will remain green during the cold weather. Thus it will furnish green feed in the late Autumn after the grasses have all died, and in the early Spring before they have started. When there is no snow, Vetch can be pastured all winter.

FOR ORCHARDS. In Michigan Sand Vetch is being used very extensively as a cover and green manure crop for orchards. Being sown in the Fall, it prevents the snow from drifting and produces a large amount of organic matter for plowing under in the spring when orchard cultiration should begin.

RYE AND VETCH. If grown in the spring with Rye or Oats as a support for the vines, Vetch will make from 10 to 15 tons of green fodder or 3 to 4 tons of cured hay per acre. Sand Vetch will thrive on soll so light and sandy that no other crop will live. The fibrous tap root reaches down to a depth of 2 or 3 feet and will get moisture. Fall sown Vetch keeps the soll from washing during the Winter and early Spring and thus saves a great deal of the soluble min. eral fertilizer which is in the soll. If plowed under it enriches the soil in the same way that Clover does, and is much cheaper than commercial fertilizer.

We belleve Vetches will prove very valuable for Western Nebraska and Eastern Colorado.

Prices. Per lb., 30c; postpaid. By freight, per lb., 20c; 30 lbs. (for 1 acre), $\$ 3.00 ;$ per bu., $\$ 6.75$. Prices subject to change.

\section{MILLETS}

60 lbs. to bu.

GERMAN MULLET. German Millet will grow in any climate or soll. It is a strong grower and will yield enormous crops of the finest hay. Sow any time between May 1st and August 1st. Price 15c per lb., postpaid. By freight 4c lb., $\$ 1.0 \overline{\text { per bu. }}$.

SIBERIAN. (Also called Red German, Dakota and Earliest Russian Millet.) It is from 2 to 4 weeks earlier than German millet, and can be cut for hay in 60 days from planting. The blades are wide, the straw fine and soft and does not make as much hay as German. millet. It stools heavily. Sow $3 / 4$ bu. broadcast or $1 / 2$ bu. in drill to the acre for hay, on rich land. Price 15c per lb., postpaid. By freight 4c per lb.; $\$ 1.05$ per bu. (50 lbs.).

JAPANESE BARNYARD MLLET. (Called "Billion Dollar Grass" owing to its high value.)
Its greatest value is for green fodder, of which it yields 3 to 5 tons per acre. It is excellent for cows, producing more milk than corn fodder. It grows 6 to 8 feet high, and produces 50 to 90 bushels of seed per acre. It should be sown to give best results the latter half of May at the rate of 10 pounds per acre. Price, per lb., 18c; 3 lbs., 50c; postpaid. By freight, per lb., 5c; 25 lbs., $\$ 1.00 ; 50$ lbs., $\$ 1.75 ; 100$ lbs., $\$ 3.25$.

HOG, OR BROOM CORN MILLET. This millet yields enormously of seed, often 60 to 70 bushels to the acre. Price 15c per 1b., postpaid. By freight 5c per lb.; $\$ 1.30$ per bu.

HUNGARIAN. (Dark Seed.) About one week earlier and requires less molsture than German millet. Price 15c per lb., postpaid. By freight $5 c$ per $1 b$. . $\$ 1.30$ per bu.

\section{Pencilaria or Pearl Millet}

It grows luxuriantly on any soil suitable for corn, especially on rich land, where it will grow 10 to 12 feet high, but cutting should commence when $21 / 2$ to 5 feet. After being cut it will stool out enormously, become thicker and during the warm weather grow with marvelous luxuriance. It also does well on poor soll. Very desirable in districts subject to drouth as it continues to grow in dry weather, though, of course, not so rapidly. Looks more like cane than millet.

Sow 2 to $3 \mathrm{lbs}$. per acre in drills 3 feet apart. Do not plant until warm weather. Price 25c per lb., postpald. By freight, 15c per lb.; 5 lbs., 65; $10 \mathrm{lbs}$. for $\$ 1.10$. 
For chickens or stock. Big Grain yielder.

\section{NEW SHALLU}

A NON-SACCHARINE SORGHUM from India, where it is extensively cultivated under the name of "Shallu."

"It is more valuable than Kaffir Corn for grain, as it yields considerably more seed, it being of stooling habit, producing all the way from three to six stalks from a single grain, and it is quite a drought register. The heads grow similar to Broom Corn, forming large heads of round, plump, white seeds. It is an excellent feed for horses and cattle, and for chicken feed it is unexcelled. Can be popped the same as Pop-corn, being more crisp than Pop-corn. When ground it makes an excellent flour for pancakes. It is more of a grain crop than a forage crop. It will produce more seed than any of the cane or sorghum family and about double the amount of either Red or White Kaffir Corn."

Sow in rows three feet apart, three to five pounds of seed per acre. For fodder, sow half to one bushel either broadcast or in drills. Give it a trial.

Price, pkt., 5c; 1 lb., 20c; 5 lbs., 90c, postpaid. By freight or express, at your expense, 1 lb., 10c; 10 lbs., 65c; 50 lbs., $\$ 2.75 ; 100$ lbs., $\$ 5.00$.

2 or 3 bu., 50 lbs. to bu., broadcast, per acre for fodder.

\section{CANE OR SORGHUM}

Feeding Value. It is known quite definitely that an acre of sorghum will produce more food value, more pounds of beef or pork, when properly fed, than an acre of corn. The main use of the crop, however, is for a winter supply of forage, and it has this advantage over corn or any other kind of grain, that it can be sown late. It furnishes fodder in 70 to 90 days and matured seed in about 100 days.

Time to Sow. Sorghum may be put in almost any time up to the middle of July. June is the best time. Sow broadcast because the fodder will grow fine, will cure better, and will give better results in feeding. Eighty days will produce a very satisfactory crop. Sow 10 lbs. in rows for cultivation.

The Soil. Select the thinnest soil and highest part of your farm for sorghum. On this soll it is not so likely to fall down in season of excessive rainfall. Molasses growers know how rich in sweetness is sorghum grown on clay soils, and the sugar is the valuable part when grown for stock feeding. Have the ground free from clods and do not plant more than one inch deep except in very light soil.

Harvesting. Harvest as late as possible to avoid hard frost, in order that the fodder will retain its sweetness and succulence. It is then cut, when sown broadcast, with a mower and allowed to dry for a week or ten days, after which it may be pul up in shocks weighing about 500 pounds and allowed to stand until fed.

Price, per 1b., 15c; postpaid. By freight, 5c per lb.; $\$ 1.05$ per bu. (50 lbs.). Subject to change. Ask for prices on Larger Lots.

Good for Chickens

KAFFIR CORN

50 lbs. to bu.

This is a most excellent fodder plant, yielding two crops of fodder during a season. It grows from five to six feet high, making a straight upright growth. The stem, or stalk, bears numerous wide leaves. The stalks keep green and are brittle and juicy, making an excellent fodder either green or dried.

The seed crop is also heavy, sometimes yielding sixty bushels to the acre. Both grain and fodder are excellent. The stalk remains tender to full maturity of seed. There is no failure about it as it possesses the quality that all the tribe possess, of going without rain without any loss of capacity to yield.

The grain is extremely valuable for feeding to poultry and will make a flour that is like wheat. Cultivated the same as our common Indian corn, requiring five pounds of seed per acre. For fodder sow one to two bushels, either broadcast or in drills.

Price, per 1b., 15c; postbaid. By freight, 5c per lb.; per bu., 85c. Subject to change. Ask for prices for larger lots.

It waits for rain

Milo Maize is an excellent grain for dryregions. It will jield 15 bushels to the acre under conditions so dry that corn will be a total fallure. When fed with some succulent feed such as alfalfa, stock beets or sorghum, it makes fine feed for fattening cattle. To prevent waste, Milo Maize should be fed in heads or ground. Plant 4 to 6 pounds per acre in rows and cultivate.

Price, per lb., 15c; postpaid. By freight, 5c per lb.; $\$ 1.05$ per bu. 

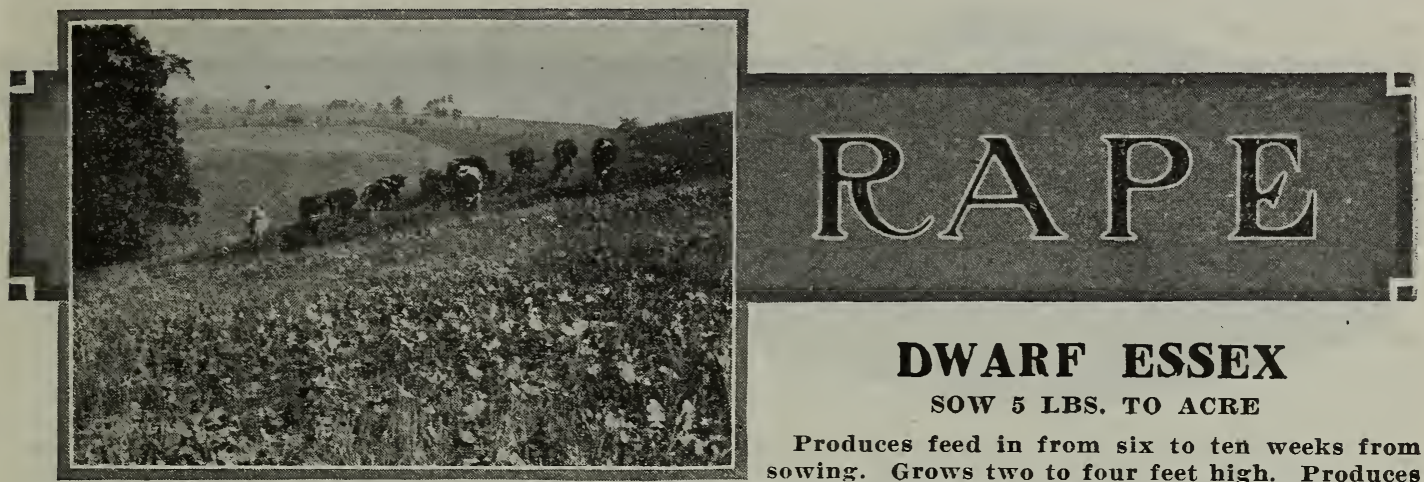

\section{DWARF ESSEX}

SOW 5 LBS. TO ACRE

Produces feed in from six to ten weeks from sowing. Grows two to four feet high. Produces from 25 to 30 tons of green feed to the acre.

When one considers that rape will produce good, succulent feed in from six to ten weeks from sowing, he can in a measure realize its value. Rape looks much like ruta baga tops, growing from two to four feet high, has broad, rich, juicy leaves which are liked very much by cattle, sheep and hogs, and continues to grow after being continually eaten off. It is estimated that the feeding qualities of rape are probably twice as great as those of clover.

Rape can be planted early for early feed; can be sown in oats and fed after the oats are cut; can be sown in corn in the last plowing. This is a good plan when the corn is to be cut green for feed, as it will leare the rape ready for pasturing after the corn is taken off. Rape is an annual, and will not become a weed or a nuisance as it does not live through the winter. We do not recommend it for cows as it may taint the milk. Stock fed on rape must have plenty of salt.

\section{FOR CHICKENS}

Rape makes the best green food for chickens. It can be sown early and the chickens will hare good, rich food all summed from one planting. They like it better than garden truck and it is much cheaper.

\section{FINE FOR HOGS}

We are satisfied that with the same preparation of the ground and with the expenditure of 25 or 30 cents per acre for seed, a man can grow as much pork from an acre of rape, well managed. as he can from an acre of corn, and grow his pork at a time of year when corn is usually high priced and often scarce.

PRICES: Genuine Imported Dwarf Essex Rape. Per lb., 18c; postpaid. By freight, per lb., 10c; 3 lbs., 25c; 13 lbs., \$1.00; 50 lbs., \$3.75; 100 lbs., \$7.25. Price subject to change.

With oats $11 / 4$ bu. per acre

2 bu. per acre if alone.

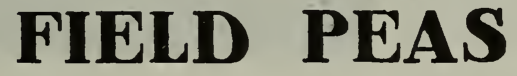

\section{Canada Field Peas}

\section{GOOD FOR PIGS}

The pigs may usually be turned into it five or six weeks after seeding, and an acre will carry from twenty-five to forty during the season. It is better to divide the field into two parts and change pastures at intervals.

\section{RAPE FOR YOUNG CATTLE}

Calves relish a small amount of rape at a very early age and do well on it when fed judiciously. Young cattle thrive on it when it is fed in connection with natural grass pasture. Steers in. tended for stall feeding or late fall marketing cannot be better cared for than be allowed the run of a good field of rape.

The Canada Field Pea is a true pea; and should be sown early in the spring, germinating at the same time as oats. It is grown very largely in some portions of Colorado as a sheep feed, and in Canada takes the place of clover, belonging as it does to the same family, which has the merit of being able to use the free nitrogen of the atmosphere.

The Canada Field Pea can be used to advantage anywhere in this state, in connection with oats; as an early feed for hogs. If sown at the same time as oats in the latitude of Lincoln it will be ready for hogs about the 25th of June. In the extreme northern part of Nebraska it would probably take to the first week in July. The peas by that time are in the dough stage and will furnish the earliest grain feed that can be grown on the farm.

Disk the ground as early as possible in the spring, sow the peas at the rate of $11 / 4$ bushels to the acre, plow under about three inches deep, then sow 1 bushel oats or barley broadcast and harrow thoroughly. If merely covered with the harrow a heavy rain will uncover a good many of them. The grain is sown to furnish support for the peas, to more fully occupy the land, and to give variety of feed. This should make from 2 to 3 tons of cured hay per acre. Price 20c per lb., postpaid. By freight, 10c per lb.; 90c peck; $\$ 3.00$ per bu. Price subject to change.

\section{Cow Peas}

COW PEAS. Highly recommended to plant with oats or Kaffir corn. increasing the fertility of the soil for the succeeding crop and leaving the ground mellow and clean from weeds. Do not plant until the weather has become warm; sow 2 bushels if alone, and 1 bushel if with other seeds. They make from 1 to 3 tons of hay per acre.

WHIPPOORWILL. Early, bunch-growing variety. Per lb., 20c, postpaid. By freight, 10c per lb.; 90c peck; $\$ 3.00$ per bu. (60 lbs.). Price subject to change.

NEW ERA. An early rariety. Maturing seed in from 80 to 100 days. Probably the best sort for North and West. Can be sown after wheat is taken off the ground and still produce a good crop of forage or peas. Prices, by mail, postpaid, 20c lb. By freight, 10c per lb.; 90c peck, bu. (60 lbs.)., $\$ 3.00$. Prices subject to change. 


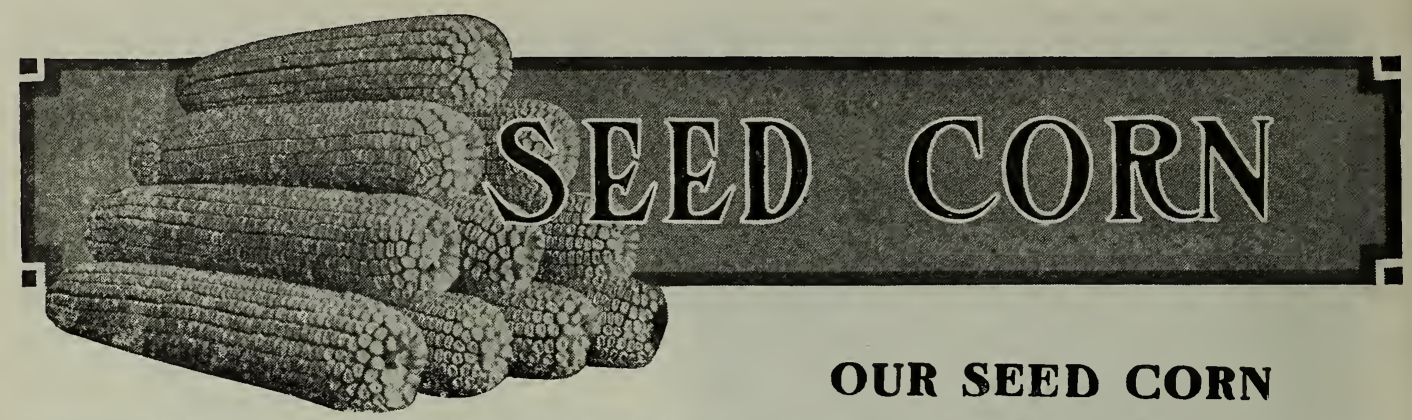

rirchasers of Griswold's Western Grown seed corn can rely upon good rarieties. All of our seed corll is prepared hyexperienced seedmen. We do not have boys in our employ in this work. Furthermore. each variety of seed corn is kept entirely separate. Our seed corn is brought to our warelouse in the ear. Here the ears are carefully hand picked and only perfect ones. with sound rorn, are sived. The poor corn goes to the grinder for feed, while the perfect ears are send to the huttin 2 alul tipling machine, which shells off the butts and tips. leaving only the perfect. regular sized keruel for seed. After shelling, the seed corn is run through a large cleaning machine. equipped with separating screens. A powerful fan oll mill blows out all trash and liøht kernels. Before our seed corn is shipped out it is placed in our Seed Tester, the plans for which were endorsed bs the Trited States Department of Agriculture. Here it must test out at least 90 per cent. Farmers cannot ruu the risk of a poor stand. Better let us furnish something that we hare tested and know is gool.

\section{B O O.VE CO. WHITE}

BOONE COUNTY WHITE.-Very best of white corn, of extra large si\%e. good yielder and medium early. (Yiality is excellent and is particu. larly adapted for milling purposes. making a fine white meal. Withstauls the dry weather and winds remarkably well. Price. Pkt., 10c: pint, 20c: quart, 30c, postpaid. By freight. $1 / 2$ peck, 40c; peck, 70c; $1 / 2$ bu., $\$ 1.25$; bu.. \$2.00; shelled only.

Polk Co., Nebr., Mar. 28, 1912.

I received the seed corn the next day after I wrote you about it. I have tested it and $I$ find it is all right. W. R. DONELSON.

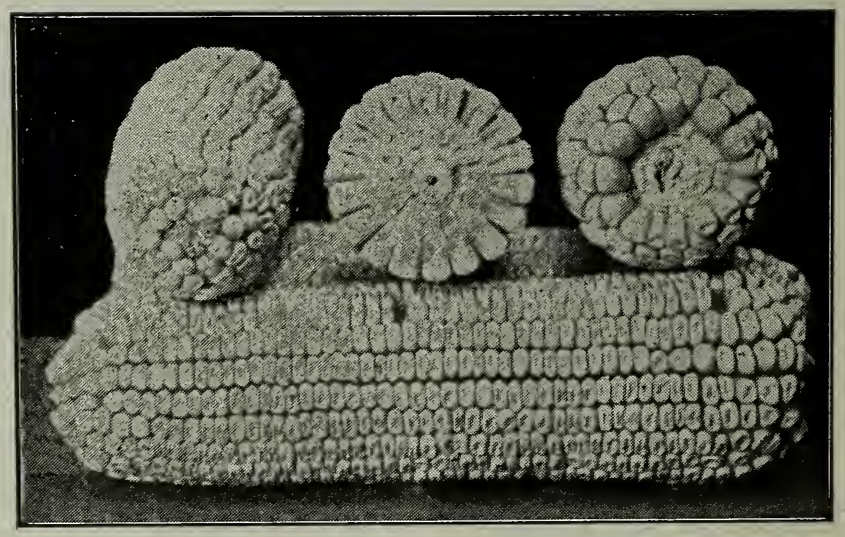

\section{UNIVERSIT Y NU. 3}

A NEW EARLY YELLOW CORN ORIGINATED BY THF NEBRASKA STATE UNIVERSITY. The following description is made by Prof. L. G. Montgomery, A. M.:

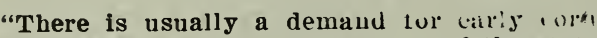
in Nebraska. In the southern part of the state uany farmers desire a small field of early corn for fall feed.

"In testing out many rarieties of farmers' corns, we chanced to test a rariety of early corn grown by a farmer in Wayne countr. It gave good results and more seed was secured in 1906 and a breeding plat established at the Experiment Station, where it has been selected since, and improved in type.

"The ear tends to be rather long. and the grain is ahout as broar as long. (olor, rellow, arerages 12 to 14 rows to the ear. Matures in 90 to 100 days, which makes it safe to plant in Southern Nebraska. June 10th to 15th. In Northern Nebraska it is just right for a full season corn."

Our seed was grown from this Unirersity stock and although the season was very un-

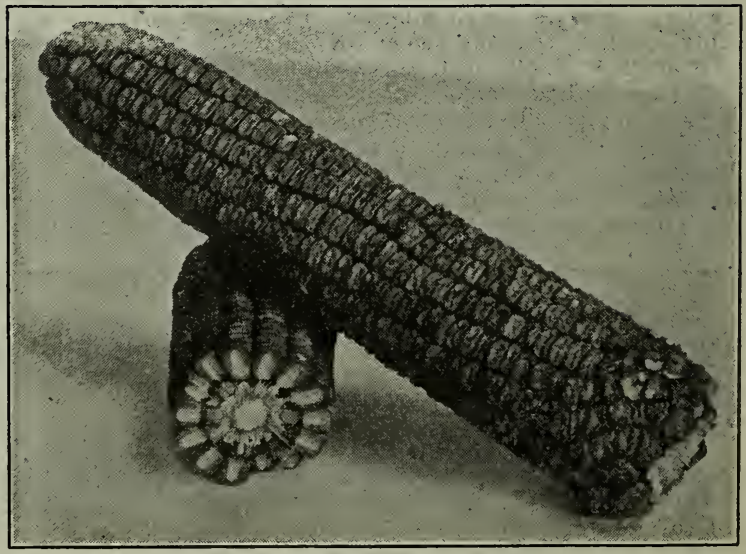

favorable it made 60 bushels per acre, field

run. Price, pkt., 10c; pt., 20c; qt., 30c; postpaid. By freight, $1 / 2$ peck, 50c; peck, 95c; 1/2 bushel, $\$ 1.50$; bushel, \$2.50. Shelled enly. 
HOGUE'S YELLOW DENT. This corn is highly endorsed by the State Experimental Station and is one of the very hest corns for Nebraska or Kansas. Ears are medium size to large, maturing in about 100 days.

PRIDE OF THE NORTH. This is a well known rariety; beautiful, deep dented, fine golden color, small ear, but a tremendous sheller. Will run about 40 to 75 bushels to the acre, ripens in 85 to 90 days. is hardy and vigorous.

IMPROVED LEAMING. A rich golden colored dent corn, good size ears, rich in protein, wedge shape kernels, medium size cob, a strong, vigorous grower, quite early, ripening in 90 to 95 days.

CALICO. That fine, large, variegated corn that always yields well and makes big ears. This corn always gets ripe before frost.

YELLOW FLINT. The corn for the extreme North. Ears long, of rich color. Very productive, outyielding any flint corn we have ever grown.

WHITE FLINT. Similar to yellow, except color. Stalks usually bear 2 or 3 long ears, having 8 to 10 rows of hard, white corn.

SILVER MINE. Stalks grow 7 or 8 feet high. every stalk has an ear, often 2 or 3 ears, set about 4 feet from the ground. Ears long, heavy, generally with 18 rows of broad, semitransparent white kernels on a white cob.

PAWNEE COUNTY YELLOW DENT PREMIUM YELLOW CORN. This corn took the highest prie of all yellow corn shown at the $1908 \mathrm{Ne}$ braska Corn Exhibit. It was selected from Reid's Yellow Dent. It has been making large yields. It yields from 75 to 80 bushels under good conditions. Give it a trial.

WHITE CAP BUTCHER. The White Cap Butcher is a medium large early red corn with white cap; will mature in 85 to 90 days and be good and sound. It is a large yielder.

NEBRASKA WHITE PRIZE. Ears are large and well filled at both ends, the white cob being hardly visible. The corn is medium early, and yields frequently 75 bushels to the acre.

GOLD MINE. The grain is a rich golden, shining like new coin from the mint; dent, long, deep; kernel often over three-fourths of an incli

\section{Corn Planters}

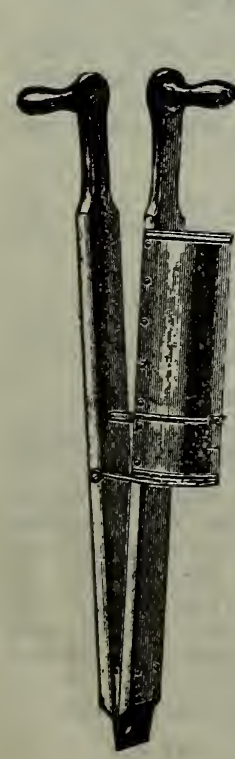

Yo. 1. Good, reliable $\mathrm{two}$ h a n d corn planter.

Price ................ $\$ 1.00$

No. 2. Segment one hand corn planter, adjustable for planting all kinds of corn. Has pump. k i n s e e d attachment, is well made in every way.

Price

$\$ 1.25$

For other Tools, Seeders, etc., see Pages 74-75.

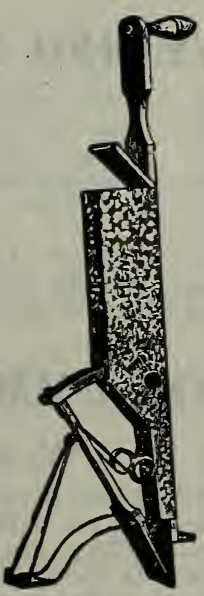

Hall Co., Nebr., 11-18-12.

We like Sand Vetch very much. We got two loads from three acres. Horses and Cows like it very much. WILLIAM MARTH. long. This corn will shell more pounds to sev. enty pounds of ears than any corn we know of.

IMPROVED REID'S YELLOW DENT. HAS a wide reputation, and is endorsed by more experimental stations than any other corn grown. Has heavy stalks wiL an abundance of blades, making extra fine fodder. It will ripen in $\mathbf{9 0}$ to 100 days and will yield from 50 to 80 bushels per acre ordinary farming.

FUNK'S YELLOW DENT, STRAIN 140. This Funk's Yellow Dent is an improvement of Reid's Yellow Dent, and has the same general characteristics. The ears are from 8 to 11 inches long, cylindrical in shape from butt to tip, with 18 to 20 rows on a small cob. The kernels set very close together with no open space between.

PRICE OF ALL ABOVE CORN

Pkt., 10c; pint, 20c; quart, 30c; postpaid. By freight, $1 / 2$ peck,, 40c; peck, $70 ; 1 / 2$ bushel, $\$ 1.25$; bushel, $\$ 2.00$. Shelled only.

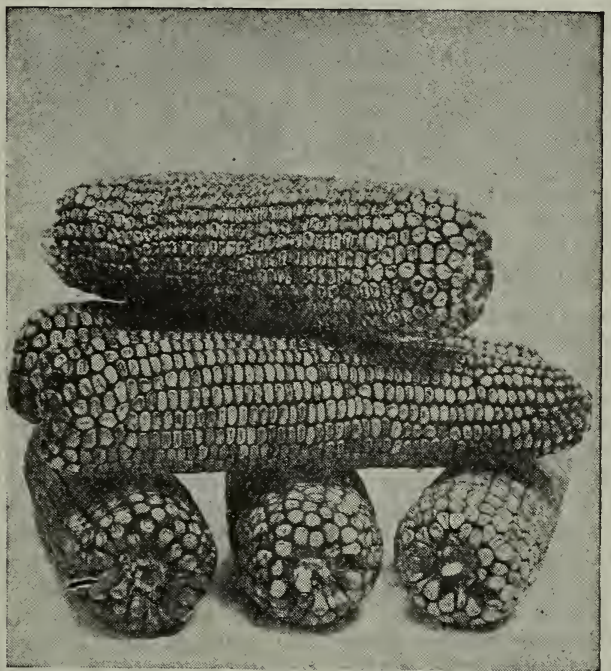

FUNK'S YELLOW DENT

\section{Combined Tipper and Sheller}

This is just the machine you have been looking for. It butts and tips your corn and then shells it. Also has an attach. ment for shelling pop corn. These machines are well made, extremely handy, you can more than pay for one by shelling and $\mathrm{tip} p$ in $\mathrm{g}$ your seed corn and then hare it for next year Price, complete....\$1.10

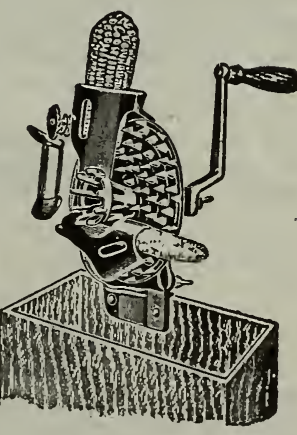

Furnas Co., Nebr., Nov. 1, '12 I have had some experience with Sweet Clover in Saline Co., Neb., and find that stock will eat it as well as alfalfa hay when properly cured.

W. H. SCHULTZ. 


\section{KHERSON OATS}

\section{Known as University Oats, No. 1}

Hardy and good yielder. Largest yield in Nebraska 112 bushels to acre; frequently yields 80 bushels per acre; two to three weeks earlier than common oats

Origin. Kherson Oats were brought to America in 1900 by the University of Nebraska, l o c a te d at Lincoln. They originally came from Kherson, Russia, where they were grown as the best extra early, hardy, good yielding oats in that locality. The Uinversity of Nehraska sent out small the state and tests proved that the oats far excelled their high. est expectations as to earliness, amount yield and adaptability
to withstand heary winds and not lodge.

Description. Kherson Oats, when ripe, are a beautiful yellow in color. They have fine large spangled or full heads, which frequently contain more than 100 seeds. A good idea is obtained from illustration, which is taken from an actual photograph. The straw is stiff and does not lodge or rust. The leaves are broad, frequently 3-4 of an inch wide. They extend to the roots and are so pliable that they stay on even through threshing. The straw makes an unusually good fodder and is eaten greedily and with profit by all kinds of stock. While the kernel is a little small, the berry, when the hull is off, is extra large. We have never found a grain so small but what it contained a well developed seed. This is not true of the large oats.
Yield. Under favorable conditions Khersou Oats have yielded as high as 112 bushels to the acre in Nebraska. At the Experimental Station at North Platte the yield averages about 50 bushels to the acre.

In a goos favorable year Kherson Oats are three weeks earlier than common oats, thus los. ing by two weeks the risk of hail and two weeks better chances for a crop.

We have never sold anything that gave such universal satisfaction. In 1905 we sold over 9,000 bushels of Kherson Oats; in 1906 almost 11,000 with increasing sales each year since. These immense amounts go out in from 3 to 50 bushel lots to almost every state in the Union, and especially Iowa, Illinois, Kansas, Missouri, and Oklahoma. All these states report the yield from 10 to 30 bushels more per acre than Texas Red, Champion and other Oats. Customers who bought these oats when we first introduced them are now buying to secure a new start.

Buy direct from us and you get the pure seedno substituting.

Sow on rich soil. Reports show that they do not lodge even on bottom land. They will not give satisfaction on poor soil. Sow $2 \frac{1}{2}$ bushels per acre.

If you order only oats, remember the freight will be no more for three bushels than one bushel.

We have handled the Kherson Oat since its adaptability to our soil and climate has been proven.

Prices, 1 bu., 80c; 5 bu., $\$ 3.75$; 10 bu., $\$ 7.00$; 25 to 50 bu. lots, per bu., 65c. These prices are sacked f. o. b. cars, Lincoln, Nebraska.

\section{REGENERATED SWEDISH SELECT OATS}

These oats were introduced for the first time three years ago. They were "crosbred" by the Garten Seed Company of England, and the system that they used was such that it increased their vitality and put them back to their original standard of high excellence. Under this system the oats were made to weigh 52 pounds to the measured bushel. We had a small lot of these oats planted for us and they yielded a little more than twice as much as common oats under the same conditions. This season we are offering oats grown from last year's stock. Our grower says, "They beat all other kinds two to one in yield and quality."

Price, by mail, 1 lb., 20c; 3 lbs., 5̄5̄c. By freight, $1 \mathrm{lb} ., 10 \mathrm{c}$; $1 / 2$ peck, 25c; 1 peck, $35 \mathrm{c} ; 1 \mathrm{bu}$., 80 c; 5 bu., $\$ 3.75$.

\section{SPELTZ OR EMMER}

Drill 2 bu., or if broadcast, $s$ bu. to the acre. 40 lbs., to the bu.

This grain resembles barley except that it has two berries in each hull. Sow it in place of oats. Grain is just as good for stock. Better than barley for hogs. It is liked by horses, sheep and cattle. Its straw makes feed equal to prairie hay. It produces from 50 to 100 bushels of seed per acre, and yields well in dry years when other small grains are a failure, and will grow anywhere in the corn belt and as far north as wheat will grow. As the grain is very rich in protein, it makes a most nutritious feed. Cut when mid- dling green, as it threshes easier, and the straw makes better hay.

Farmers who planted this seed last year found it to be a most valuable crop for dry seasons. While it grows just as well in the eastern part of this state as wheat, oats and other grains, it is especially valuable where the rainfall is light. Price, 1 lb., 25c postpaid, 35c. By freight, per bushel $(40$ lbs. $), 80 \mathrm{c} ; 10$ bu. 1ots. $75 \mathrm{c}$. Price subject to change.

BLACK WINTER SPELTS. See next page. 


\section{BARLEY}

\section{PRICES GOOD TILL FEBRUARY 1, ONLY}

WHITE HULLESS. A valuable variety, has large heads, plump kernels, both hulless and beardless and looks like large white wheat. It is two or three weeks earlier than any other barley and an immense yielder. As it stools wonderfully, sow only $1 \frac{1}{2}$ bushels per acre. $\$ 2.00$ per bushel.

COMMON. Succeds best on lands more sandy and lighter than those adapted to wheat. Sow from 2 to $2 \frac{1}{2}$ bushels per acre. Per bu., $\$ 1.35$.
MANDSCHEURI. It is an early six-rowed rariety, maturing 80 to 90 days from the time of sowing; is rery strong strawed and stools well, bearing large heads of plump grain, adapted to all kinds of soil and climate. Per bushel, $\$ 1.50$.

CHAMPION. It is beardless and nice to handle. Grows tall and stands up well. Straw is good and grows taller than any other variety. Per bushel, $\$ 1.50$.

\section{Broom}

OKLAHOMA DWARF. This variety possesses several features of merit which distin. guish it from others and place it at the head, viz.: Its earliness, dwarf habit (5 feet high), robust growth, extreme productiveness, long, well-fibered brush and above all, its ability to resist drouth. Prices, per 1b., 20c, postpaid. By express or freight, 25 lb. lots, per $1 \mathrm{~b} ., 4 \mathrm{c}$; per bu., \$1.75.

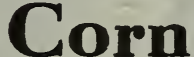

MPROVED EVERGREEN. The best variety for general cultivation on account of color and quality of brush. Price, 15c per lb., postpaid. Bj freight, per lb., 5c; per bu., $\$ 1.50$.

DWARF. Grows from 3 to 4 feet high, straight brush. Used for making whisks and brushes. Price, 1 lb., 15c, postpaid. By freight, per lb., $5 c$; per bu., $\$ 1.50$.

\section{Macaroni Kubanka Wheat}

This wheat is tall, with broad, smooth leaves. The heads are large, heavily bearded, and have much the appearance of barley. The kernels are large, very hard, having less starch than common wheat. Largely used in the manufacture of Macaroni, and makes excellent flour.

The habit of growth adapts Macaroni Wheat to regions of light rainfall, having great ability to

Turkey Red Winter Wheat, Flax and Winter Rye-Ask for Prices in Fall. withstand drought and heat. It requires rich soil, but will grow in alkali.

Reports show a better yield per acre of Macaroni or Durum Wheat than other spring rarieties. Sow early in the spring, as it is not easily injured by frost. Price, 50c per peck; $\$ 1.40$ per bu.; 2 to 10 bu., $\$ 1.30$ per bu.
Seeds in y0 $_{0}$ to

76 days

\section{Buckwheat}

rounder than the common variety, matures earlier, and yields a half more to the acre. Lb., 20c; 3 .lbs., 45c; postpaid. By express or freight, peck, $60 \mathrm{c}$; bu., $\$ 2.00$.

COMMON. Sown in June, broadcast, at the rate of 2 to 3 pecks per acre. Lb., $25 \mathrm{c} ; 3$ lbs., 60c; postpaid. By freight or express, peck, $60 \mathrm{c}$; bu., $\$ 1.95$.

SILVER HULL. A very good and popular variety. The grain is of light gray color, is

\section{Winter Wheat and Black Speltz}

BLACK WINTER SPELTZ. Is larger, darker in color, heavier in straw and head, with larger stooling power and is much more hardy and prolific than the original type. A good drouth resister. It should succeed any place where winter wheat can be grown.

BUFFUM's No. 17 WINTER WHEAT. ..Is the only Beardless Winter Wheat which is hardy and drouth resistant. It is a native of the mountain region. An extraordinary winter wheat for dry farming. An excellent yielder.

Send in your name now for Fall Catalogue for Prices.

\section{On Alkali Lands You Can Sow}

BROME GRASS

CANADA FIELD PEAS

\section{SORGHUM}

SAND VETCH
COMMON MILLET

SWEET CLOVER

DWARF ESSEX RAPE CORN SAVER BEET 


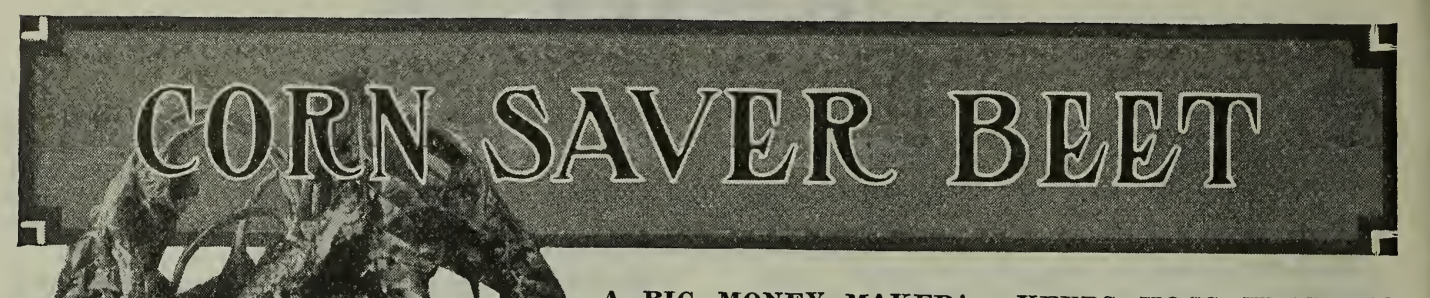

\section{A BIG MONEY MAKER! KEEPS HOGS HEALTHY!}

Fattens Hogs for One-Tenth the Price of Corn

A Money Maker. Some three years ago we, like other farmers, began wondering how we could fatten hogs without feeding so much high priced corn. After considerable experimenting along the line of feeding alfalfa hay, beets, etc., we finally decided sugar beets the better thing, for sugar is alway's fattening. That year we secured from Germany a new sugar beet that was extra rich in sugar considering its size and other qualities. We tried it out thoroughly and it proved to be all we could desire. We decided to name it CORN SAVER BEET. We have sold this beet all over the United States and the people are writing us in glowing terms how much they like it and how valuable they have found it for feeding not only hogs, but also milk-cows, cattle and calves.

How to Feed. .. We began feeding our hogs 1-3 corn, 1-3 alfalfa hay and 1-3 of the new CORN SAVER BEET. The amount of alfalfa hay and corn can be reduced from time to time until you will not have to average more than one small ear of corn to each hog, with very little alfalfa hay and the balance CORN SAVNR BEET. Give them all they can eat and the hogs will get rolling fat and healthy. Our experience proves we have struck something that will make the profit on hog raising several times greater than heretofore, and believe will entirely do away with hog cholera.

Yield. Our largest yield was close to 80 tons per acre. The beets grow very large, frequently weigh $28 \mathrm{lbs}$. They grow about half out of the ground and are thus very easily harvested. They are two or three times as large as the regular factory sugar beet and are much better for stock.

Amount to Sow. It is an easy matter to raise these CORN SAVER BEETS. Simply sow on deep plowed soil, $10 \mathrm{lbs}$. to the acre, from April to June, in rows 18 inches to 2 feet apart. Thin plants to 8 inches in the row-transplant young plants to fill vacancies. Cultivate thoroughly with a fire-tooth cultivator or an ordinary one row corn cultivator and you will have one of the largest money making crops you ever raised. Beet hulls are thick. If it is dry soak seed 24 hours in water before planting.

Price. By freight, $10 \mathrm{lbs}$. (enough for 1 acre), $\$ 4.50 ; 5$ lbs., $\$ 2.00 ; 1$ lb., 45c. By mail, 1 lb., 55c; $1 / 2$ 1b., 30c; oz., 10c; pkt., 5c.

\section{TABLE}

Showing Number of Pounds to the Bushel, and amount of Seed Necessary for an acre.

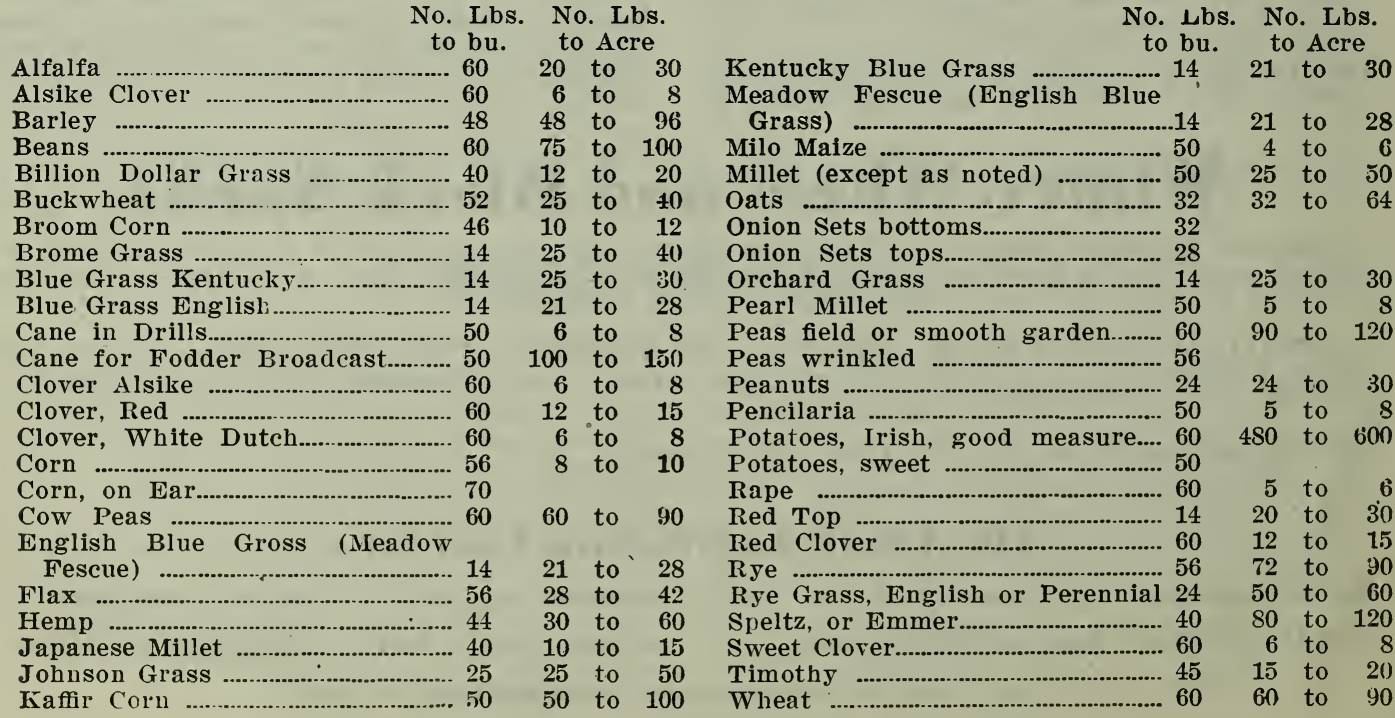




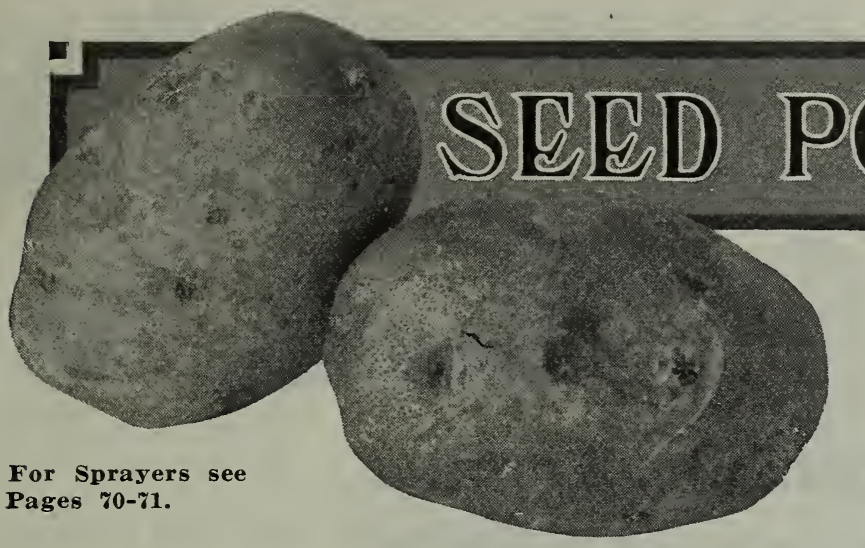

All Potato Prices Subject to Advance RED RIVER EARLY OHIO, OUR NEBRASKA SPECIALTY. MATURES EARLY, HEAVY YIELDER, AND A VIGOROUS GROWER.

8 to 12 Bushels of Seed Required to the Acre. One Peck will Plant About 100 Hills.

IMPORTANT.-Seed potatoes should be cnanged every year. The necessity for doing so is universally admitted by all potato growers, especially when the best seeds can be had at so little additional outlay.

Our Northern Grown Seeds were produced by potato specialists, who have grown for us for years. They use first-class potato land, pure, well-matured, good sized seeds. When necessary tney treat the seeds and spray the foliage.

\section{RED RIVER EARLY OHIO}

This is the most popular early potato in this country. We have more calls for it than any other early variety. Every potato grower knows what it is, and knows just about what it will do in his locality. It is the standard extra early the world over, and other varieties are measured by it. We have an extra choice strain of Early Ohio. Our Red River Valley stock, grown in North Dakota last fall, is the earliest, purest, and altogether the handsomest stock of Early Ohio potatoes to be found anywhere, and as fine as one cares to see. The tubers are smooth and regular in shape, free from prongs, perfectly pure and full of vigorous life. They are selected with the utmost care, and the result is grand, such as to delight everyone who knows and appreciates a good potato. Price, peck, 35c; bu., $\$ 1.10$; barrel (net $165 \mathrm{lbs}$ ), $\$ 2.90 ; 25$ bu. lots or over at $\$ 1.00$ per bushel, sacked. These prices good till Feb. 1st. Ask for price when you are ready to order.

\section{EXTRA EARLY POTATOES}

ACME. The most profitable early potato in cultivation. Fit to eat in six weeks and crop fully matured in ten weeks from planting. Prolific yielder; tubers are oblong, smooth; skin flesh color; flesh white; upright strong vines with tubers growing compactly in the hill. Eyes shallow, quality excellent, mealy and of fine flavor. Keeps well. Price, peck, 40c; bu., 1.25; barrel (net $165 \mathrm{lbs}$.). $\$ 3.60$.

EARLY SIX WEEKS. Another potato of the Ohio type in great demand. Not the heaviest yielder, but good sized, smooth, round to oblong, tubers in eating condition before the well-known Early Ohio. Grown in Nebraska. Price, peck, 40c; bu., $\$ 1.25$; barrel (net $165 \mathrm{lbs}$ ), $\$ 3.60$.

RED TRIUMPH. Earlier than any other desirable for the first "new potatoes." Tubers nearly round, medium in size, reddish pink in color. Price, peck, 55c; bu., $\$ 1.25$; barrel (net 165 lbs.), $\$ 3.60$.

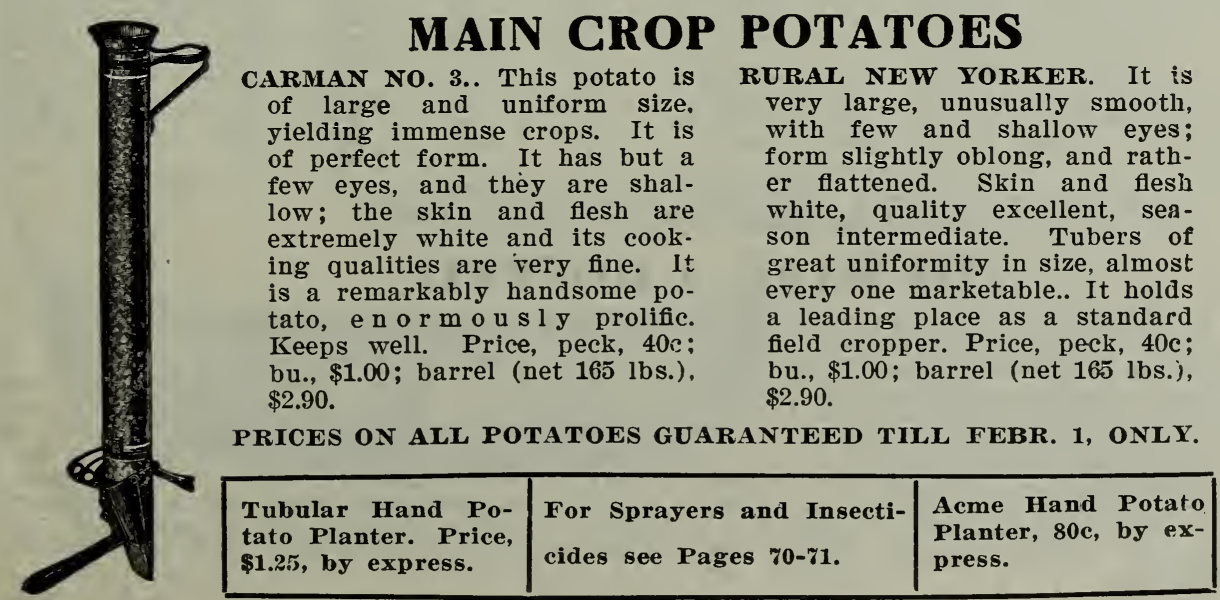

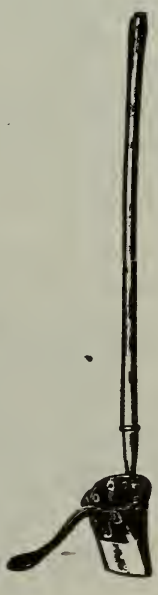




\section{$14 \quad$ Griswold Seed Company, Lincoln, Nebraska}

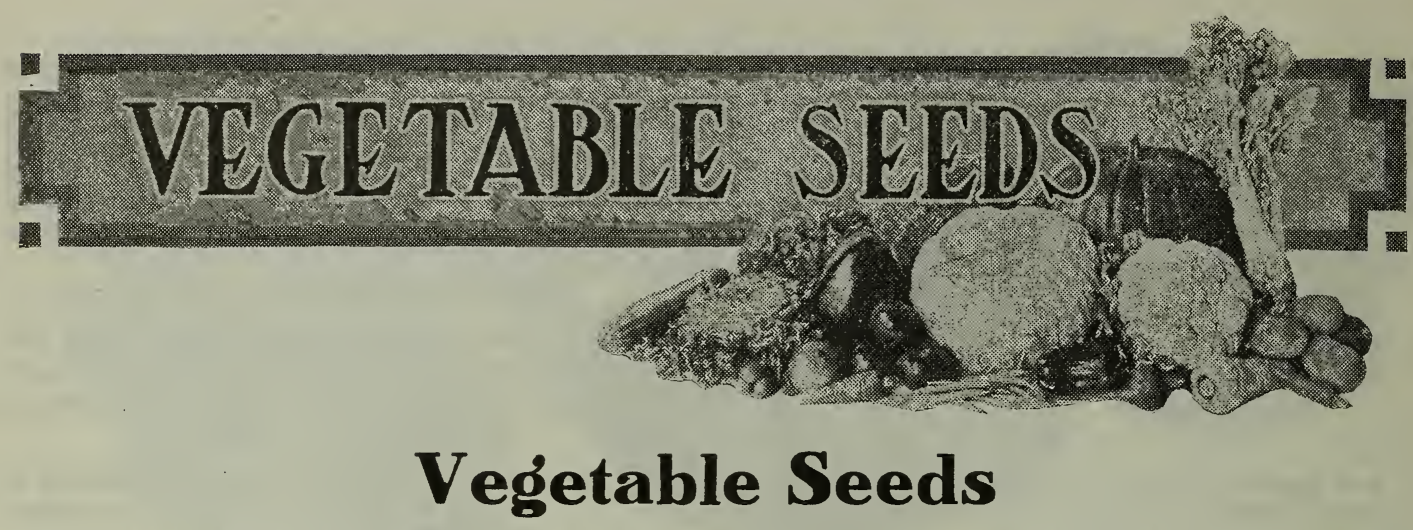

At prices named we pay postage on all seeds ordered by the Packet, Ounce, Pound, Pint and Quart. DISCOUNT ON SEEDS IN PACKETS

ANY 6 OF OUR LARGE 5c PACRAGES FOR 25e

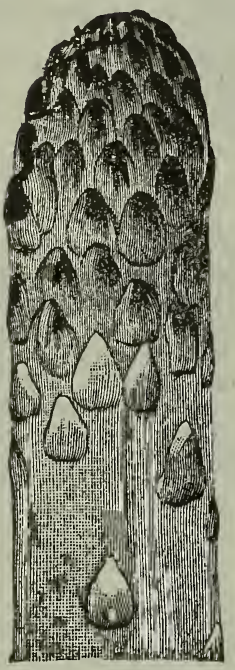

\section{ASPARAGUS 1 oz. to 50 ft. of drill; SPARGEL}

Sow in March or April, in good mellow soil, after soaking the seed 24 hours in warm water, in drills one foot apart, and one inch deep. During the sum. mer keep the soil mellow and free from weeds, thinning the plants to 4 inches apart. The following spring transplant into permanent beds that have been deeply dug and highly manured.

CONOVER'S COLOSSAL. A mammoth, green sort of the best quality. Pkt., 5c; oz., 10c; $1 / 4$ lb., 25c; lb., 70c; postpaid.

BARR'S MAMMOTH. An early, large-stemmed, green variety. Pkt., 5c; oz., 10c; $1 / 4$ lb., 25c; lb., 70c; postpaid.

PALMETTo. An early, green sort, prolific and very desirable. Pkt., 5c: oz., 10c; $1 / 1$ lb., 25c; lb., 70c; postpaid.

COLUMBIAN MAMMOTh WHITE. Produces white stalks of large size and finest quality. Pkt., 5c; 0z., 10c; 1/4.1b., 25c; lb., 70c; postpaid.

ASPARAGUS ROOTS

The ground should be well manured and deeply spaded, the roots planted two feet apart, one foot apart in the row, and at least six inches deep. These will be ready to use in two to three years. $15 \mathrm{c}$ per dozen; 50 for $60 \mathrm{c} ; \$ 1.00$ per 100, postpaid; 35c for 50;60c per 100 , by express at your expense.

\section{ASPARAGUS CULTURE}

A book giving all possible details as to Growing, Soil, Marketing, Canning, etc., for home use or market, 174 pages. Cloth, 50c; postpaid.

\section{VEGETABLE PLANTS}

We Grow Great Quantities of Cabbage, Cauliflower, Celery, Tomato and Sweet Potato Plants Postpaid By Exp., Your Expense

Early Cabbage, most leading varieties Late Cabbage, most leading varieties Early Tomato, most leading varieties. Late Tomato, most leading varieties............ Cauliflower, Snowball ...................................................... 10

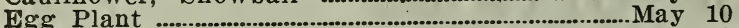
Early Celery, most leading varieties............................. 10 Late Celery, most leading varieties.............................June 1 Pepper, most varieties ....................................................... 10 Sweet Potato, Yellow Jersey \& Nansemond.......May 10 Asparagus Roots

Rhubarb Roots

$10 \mathrm{c}$ each

$\begin{array}{ccr}\text { per doz. } & \text { per } 25 & \text { per } 100 \\ \$ 0.15 & \$ 0.25 & \$ 0.75 \\ .10 & .20 & .65 \\ .25 & .45 & 1.00 \\ .15 & .30 & .90 \\ .25 & .45 & 1.25 \\ .25 & .45 & 1.25 \\ .20 & .35 & .75 \\ .15 & .25 & .55 \\ .25 & .45 & 1.25 \\ \ldots \ldots & . . . . . . & . .50 \\ .15 & \ldots \ldots & 1.00 \\ 1.00 & \text { per doz } & \end{array}$

$\begin{array}{rrr}\text { per doz. per } 100 & \text { per1000 } \\ \$ 0.10 & \$ 0.50 & \$ 4.00 \\ .10 & .40 & 2.50 \\ .15 & .80 & 7.00 \\ .10 & .70 & 6.00 \\ .20 & 1.00 & 7.00 \\ .20 & 1.00 & 8.00 \\ .15 & .50 & 4.00 \\ .10 & .35 & 3.00 \\ .20 & 1.00 & 8.00 \\ \ldots . . . . & .30 & 2.50\end{array}$

50c per doz.

\section{WRITE FOR PRICES IN LARGER LOTS}

\section{TO MAKE A HOTBED}

A hotbed should face the south or southeast, be located on well drained ground, and if possible be protected on the north by a building or high fence.

$6 \times 10$ feet will be large enough for an acre garden. Sashes are usually $3 \times 6$ feet. Dig a trench 2 feet deep, around this place a frame 16 inches high at the back and eight inches in front. Fill the hole with fresh horse manure that has lain for a week or ten days, tramping it down firmly and covering with 4 inches of fine, rich, black soil. Place the sashes over the frame. After standing a few days lift the sashes to allow the rank heat and steam to pass off: when the temperature has subsided to 90 degrees $F$. sow the seed. It is best to bank the outside of the frame up to the sash. The hotbed may be all above ground by making a pile of manure 2 feet high, and 3 feet longer, and 2 feet wider than the frame, fill in with black soil and complete as directed for the excavated bed. When plants are nearly ready for outside lift the sashes every pleasant day, gradually hardening off the seedlings.

Frame and shades should be stored away at the close of the season and will thus last for years. 


\begin{tabular}{|c|c|c|}
\hline $\begin{array}{l}\text { FOR PRICES ON LARGER } \\
\text { LOTS SEE OUR } \\
\text { MARKET }\end{array}$ & & $\begin{array}{c}1 \text { PINT TO } 100 \text { FEET OF } \\
\text { DRILL; } 1 \text { BUSHEL PER } \\
\text { ACRE }\end{array}$ \\
\hline $\begin{array}{l}\text { GARDENERS' PRICE LIST } \\
\text { SENT FREE }\end{array}$ & BUSCH BOHNEN & 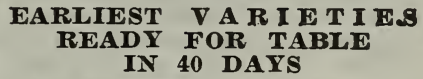 \\
\hline
\end{tabular}

The soil best adapted to beans is a light rich, well d $\mathrm{r}$ a in ed loam, which was manured for the previous crop. Beans are extremely sensitive to both cold and wet, and it is useless to plant them before.the ground has become dry and warm. The largest returns will result from planting in drills from two to three feet apart, and leaving the plants two to six inches apart in the row. Up to the time of bloosoming they should have frequent sh a llow cultivation. Never hoe when the vines are wet, as the pods would become discolored. For succes. sion plant every two weeks.

If by express at buyer's expense you may deduct $8 \mathrm{c}$ per pint; 15c per quart.

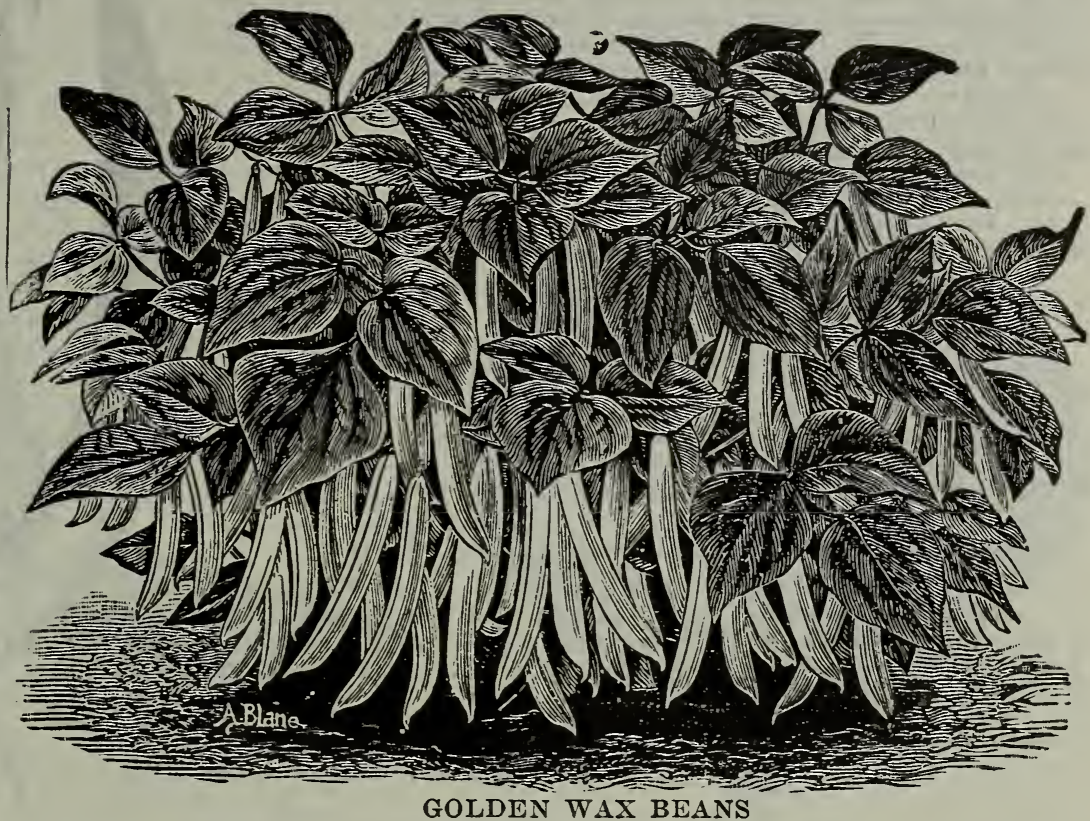

\section{BUSH OR SNAP}

Wax or Yellow Pod Varieties

GOLDEN WAX. A standard sort. One of the earliest beans in the market. The pods are of good length, flat, but quite thick and broad. They are waxy, golden yellow, and of fine, buttery flavor. Hardy and productive. Pkt., 5c; pt., 25c; qt., 40c; postpaid.

IMPROVED GOLDEN WAX. Pods are thicker than those of Golden Wax, and of better quality. Pkt., 5c; pt., 25c; qt., 40c; postpaid.

GERMAN BLACK WAX. A popular variety; pod a waxy yellow, solid, tender, almost transparent, stringless, seeds when ripe jet black. Pkt.. 5c; pt., 25c; qt., 40c; postpaid.

CURRIE'S RUST PROOF WAX. The vine is very vigorous, hardy, and an early and abundant bearer. The pods are long, flat and straight, and of a light yellow color. The beans when ripe are a bluish black. It is an excellent shipper. Pkt., 5c; pt., 25c; qt., 40c; postpaid.

DAVIS' KIDNEY WAX. The large beans are pure white, kidney shape, excellent for cooking, green or dry. The pods while young are stringless, tender and of excellent flavor, very long, straight, flat, and clear, waxy white. Very productire. Pkt., 5c; pt., 25c; qt., 40c; postpaid.

WARDWELL'S KIDNEY WAX. Pods long, flat, nearly straight, white, handsome and of good quality. One of the very best beans, large, kidney shaped, white with dark markings about the eye. Pkt., 5c; pt., 25c; qt., 40c; postpaid.

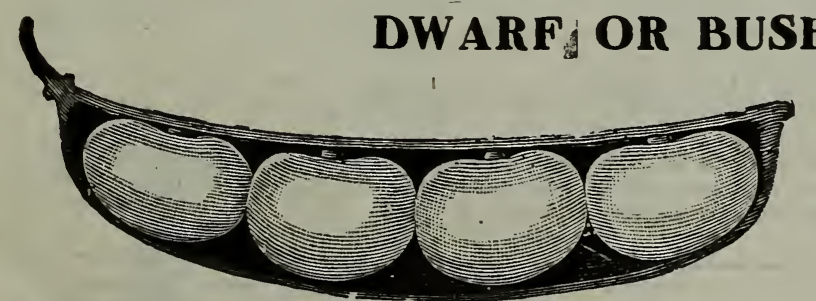

\section{LIMA BEANS}

The Bush Limas are quite desirable for the garden, as their cultivation does awaj with poles. These should be planted edgewise with the eyes down and two inches deep. Plant June 1st.

HENDERSON'S BUSH LIMA. Grows in compact bush form about 18 inches high. The beans are small in size, but of de. licious flavor and great productiveness, and about two weeks earlier than the others. Pkt., 5c; pt., 25c; qt., 45c; postpaid.

BURPEE'S BUSH LIMA. A bush form of true large Lima. A good yielder, bearing a handsome large pod, well filled. Pkt., 5c; pt., 25c; qt., 45c; postpaid. 


\section{DWARF GREEN PODDED BEANS}

BURPEE'S NEW STRINGLESS. One of the best stringless green-podded beans in cultivation. The pod is round, full, large and straight. In quality it is superior to most other Bush Beans. Pkt., 5c; pt., 25c; qt., 40c; postpaid.

IMPROVED RED VALENTINE. Early and prolific. Pods are remarkably fleshy and tender, and remain a long time without becoming hard. Pkt., 5c; pt., 25c; qt., $40 \mathrm{c}$; postpaid.

LONG YELLOW SIX WEEKS. Hardy, early and productive. A standard sort. Pkt., 5c; pt., 25c; qt., $40 \mathrm{c}$; postpaid.

REFUGEE (THOUSAND TO ONE. ) Most prolific green-podded sort, thick and fleshy. Especially desirable for pickling. Pkt., 5c; pt., 25c; qt., 40c; postpaid.

WHITE MARROW. Good shelled, either green or dry. Pkt., 5c; pt., 25c; qt., 40c; postpaid.

LITTLE WONDER NAVY. Valuable for field culture; very prolific, excellent dry bean. Pkt., כc; pt., 20c; qt., 3こ̃ ; postpaid.

GIANT STRINGLESS. This extra early variety is exceedingly productive, bearing round green pods 6 to 7 inches long, very meaty, extremely crisp and absolutely stringless throughout the entire season. Pkt., 5c; pt., 25c; qt., 40c; postpaid.
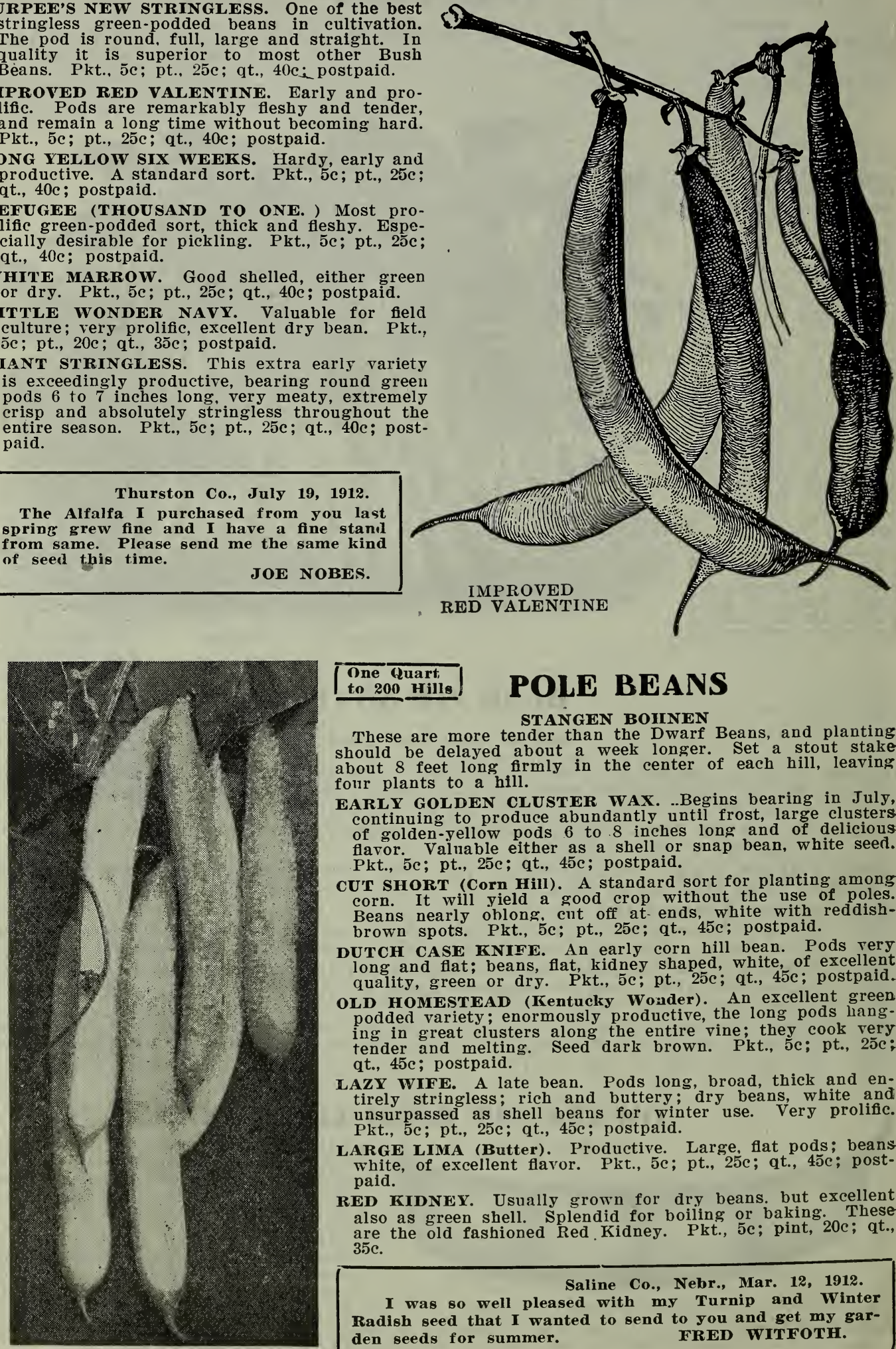

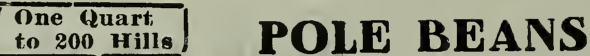

The Alfalfa I purchased from you last spring grew fine and $I$ have a fine stanil from same. Please send me the same kind of seed this time.

JOE NOBES.

\section{POLE BEANS}

\section{STANGEN BOHNEN}

These are more tender than the Dwarf Beans, and planting should be delayed about a week longer. Set a stout stake about 8 feet long firmly in the center of each hill, leaving four plants to a hill.

EARLY GOLDEN CLUSTER WAX. ..Begins bearing in July, continuing to produce abundantly until frost, large clusters cof golden-vellow pods 6 to 8 inches long and of delicious flavor. Valuable either as a shell or snap bean, white seed. Pkt., 5c; pt., 25c; qt., $45 \mathrm{c}$; postpaid.

CU'T SHORT (Corn Hill). A standard sort for planting among corn. It will yield a good crop without the use of poles. Beans nearly oblong. cut off at- ends, white with reddishbrown spots. Pkt., 5c; pt., 25c; qt., 45c; postpaid.

DUTCH CASE KNIFE. An early corn hill bean. Pods rery long and flat; beans, flat, kidney shaped, white, of excellent quality, green or dry. Pkt., 5c; pt., 25c; qt., 45c; postpaid. OLD HOMESTEAD (Kentucky Wouder). An excellent green podded variety; enormously productive, the long pods lianging in great clusters along the entire vine; they cook very tender and melting. Seed dark brown. Pkt., 5c; pt., 25c; qt., 45c; postpaid.

LAZY WIFE. A late bean. Pods long, broad, thick and entirely stringless; rich and buttery; dry beans, white and unsurpassed as shell beans for winter use. Very prolific. Pkt., 5c; pt., 25c; qt., 45c; postpaid.

LARGE LIMA (Butter). Productive. Large, flat pods; beans white, of excellent flavor. Pkt., 5c; pt., $25 \mathrm{c}$; qt., 4 ๘̌c; postpaid.

RED KIDNEY. Usually grown for dry beans. but excellent also as green shell. Splendid for boiling or baking. These are the old fashioned Red Kidney. Pkt., 5c; pint, 20c; qt., 35c.

Saline Co., Nebr., Mar. 12, 1912.

I was so well pleased with my Turnip and Winter Radish seed that I wanted to send to you and get my garden seeds for summer. FRED WITFOTH. 
ONE OUNCE TO 100 FT.

OF DRILL, 5 to 7 LBS.

TO ACRE IN DRILLS.

\section{BEETS}

\section{ROTHE REUBEN OO RUNKLE-REUBEN}

The early turnip varieties are ready for the table in from 50 to 60 days from sowing seed.

The best results are obtained on a deep, rich sandy loam, in freshly prepared soil, which should be pressed firmly over the seed. In dry weather soak seed 24 hours before planting.

If wanted very early, sow in hotbeds and transplant, cutting off the outer leaves. For general crop sow in drills 18 inches apart, and thin to three inches in the row. For winter use, the turnip varieties may be sown in June, and the beets may be kept by storing in a cellar and covered with sandy soil to prevent wilting. To prevent beets losing their color in cooking, do not break the skin. Prices are all postpaid. If sent by express deduct 10 cents per pound.

BEST EARLY BLOOD TURNIP. Dark red, fine flavor, good for winter.

CROSBY'S EARLY. An improved strain of the Egyptian; skin and flesh are dark red, roots smooth, round, fine quality, extra early.

ECLIPSE. An extra early variety with round, smooth, blood-red roots. Matures very early and is popular both for market and home garden.

DEWING'S EARLY RED TURNIP. Of good form and flavor. Flesh and top deep blood-red; excellent for early or winter use.

DETROIT DARK RED TURNIP. A grand beet for bunching for market, and for the home garden. Tops small; roots globular, skin smooth; dark blood-red; flesh bright, crisp, tender, sweet and remaining so for a long time.

CoLUMBIA. Extra early, also one of the finest main-crop beets for market or home garden. The roots are turnip shape, 3 or 4 inches in diameter, deep through, smooth and entirely free from small rootlets. - Flesh deep blood-red, tender and of rich fiavor.

CRIMSON GLOBE. Early, of medium size, uniformly round; color deep crimson throughout, exceedingly tender and sweet and a good keeper.
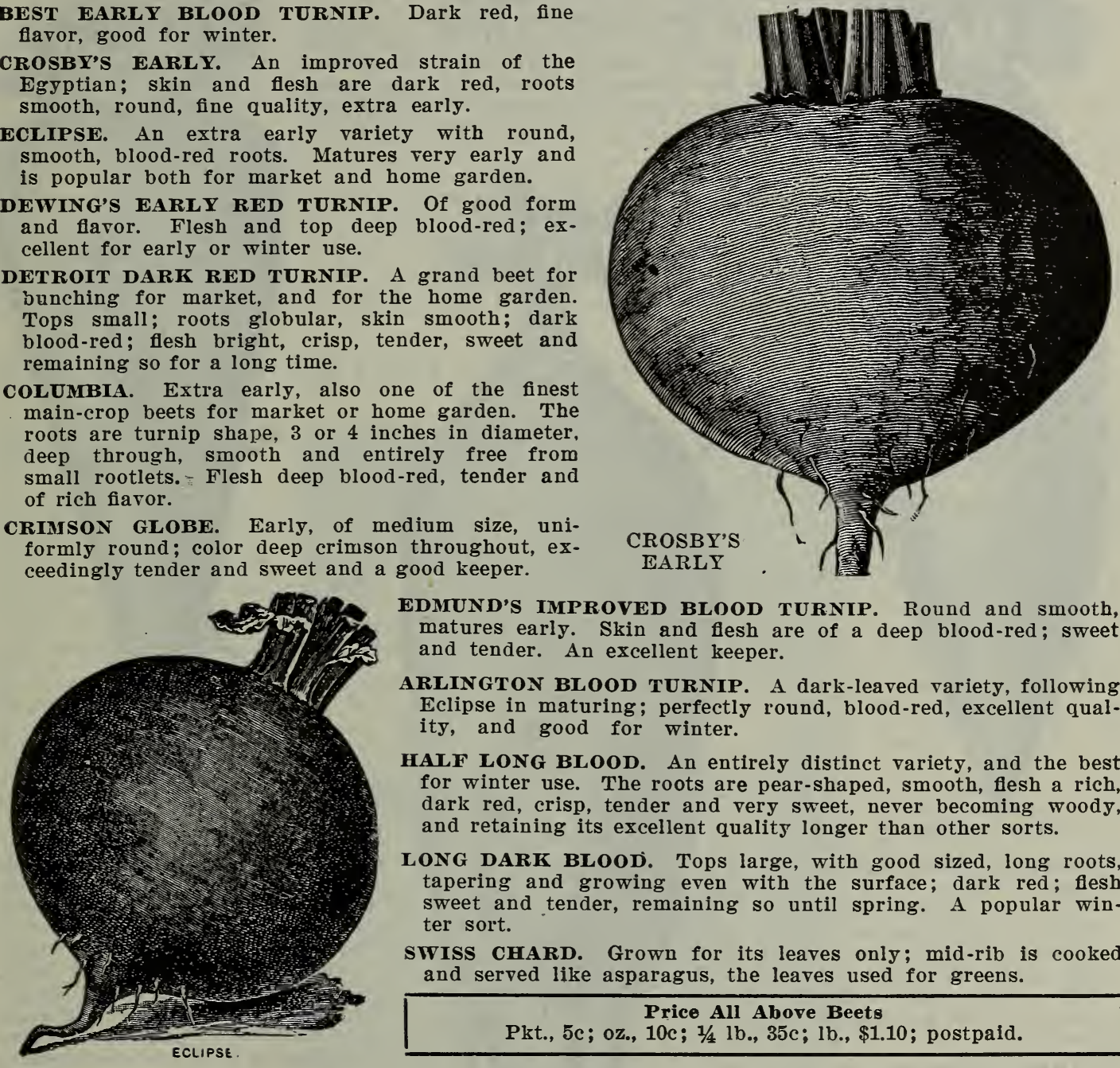

EDMUND'S IMPROVED BLOOD TURNIP. Round and smooth, matures early. Skin and flesh are of a deep blood-red; sweet and tender. An excellent keeper.

ARLINGTON BLOOD TURNIP. A dark-leaved variety, following Eclipse in maturing; perfectly round, blood-red, excellent quality, and good for winter.

HALF LONG BLOOD. An entirely distinct variety, and the best for winter use. The roots are pear-shaped, smooth, flesh a rich, dark red, crisp, tender and very sweet, never becoming woody, and retaining its excellent quality longer than other sorts.

LONG DARK BLOOD. Tops large, with good sized, long roots, tapering and growing even with the surface; dark red; flesh sweet and tender, remaining so until spring. A popular winter sort.

SWISS CHARD. Grown for its leaves only; mid-rib is cooked and served like asparagus, the leaves used for greens.

Price All Above Beets
Pkt., 5c; oz., 10c; $1 / 4$ lb., 35c; lb., $\$ 1.10 ;$ postpaid.

\section{Brussells Sprouts}

\section{SPROSSEN KOHL}

Matures 140 to 150 days from seed

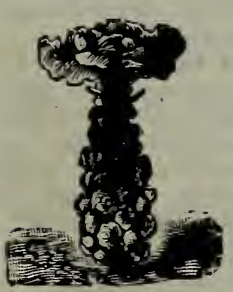

Culture-Same as winter cabbage. Break down the leaves in the fall to force the growth of the sprouts.

The plants grow two to three feet high, and produce miniature heads from the sides of the stalk. These heads, after they have been touched by frost, become very tender; bolled in the same way as cauliflower. Pkt., 5c; oz., 15c; $1 / 4$ lb., 45c; postpaid. 


\section{MANGEL WURZEL AND SUGAR BEET}

\section{PRICE}

Ounce, 10c; $1 / 4$ pound, $15 \mathrm{c}$; pound, 50c; postpaid. By freight, 5 pounds, $\$ 1.75 ; 10$ pounds, $\$ 3.25$.

\section{For Stock Feeding}

When the fact is considered that 50 tons of Mangel Wurzel may be grown on a single acre, at a small outlay, the wonder is that every farmer does not profit by it. Mangels grow to a larger size and will produce a greater bulk of roots per acre than sugar beets, but the latter are richer in qual-

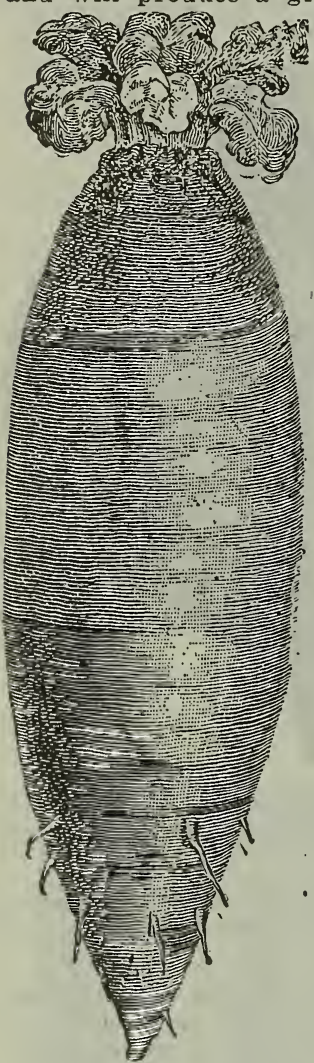

LANE'S IMPERIAL SUGAI:

MAMMOTH LONG RED (Dignity). This is truly a mammoth, a single root often weighing 30 pounds. Enormously productive, smooth and regular in shape, with a small top. They grow half above ground, and are easily harrested.

GOLDEN TANKARD. A superior strain of golden fleshed mangel; roots half long and very large. It is particularly rich in milk-producing qualities. It is very easily pulled; exceedingly hardy.

GIANT HALF SUGAR MANGEL. The roots of ihis new manges are more valuable, pound for pornd, than those of the best strains of sugar heet. supplying food of very much higher nutritive value and not only are they of better quality but they yield more than twice as much. 'I'he roots grow partly out of the ground, which 1. nnllers the harvesting of the crop very easy. Every progressive farmer should try this new lood.

For prices see top of page.

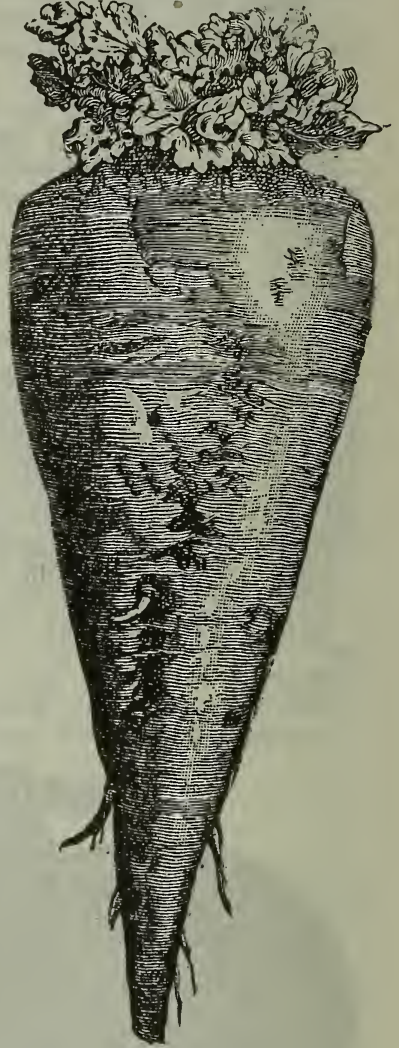

KLEIN'S WANZLEBEN SUGAR KLEIN'S WANZLEBEN SUGAR BEET. This is considered the most desiráble variety for sugar. It is also desirable for feeding to stuck. The roots. while rather shorter than some varieties, are thicker in diameter, and yield an immense crop on rich land. The largest diameter is at, or just below, the surface of the soil, then tapering rather quickly.

LANE'S IMPERIAL SUGAR. This beet grows to a large size, will yield almost as much in bulk as the best mangels, and contains a large percentage of

MAMMOTH LONG Wuar The roots are smooth broad at the shoulder and gradually taper to the base. They grow with a considerable portion above the soil, and are easily harvested. Gray top, whitish. green skin, with crisp, snow-white flesh.

RIVENHALL GIANT YELLOW GLOBE. This is the cleanest growing, heaviest cropping and longest keeping globe variety in cultivation. Notwithstanding its great size it produces only a small top with a single tap root.

For Corn Saver, the new hog beet, see page 12. 


\section{FOUR LINCOLN RAMBL̄ER ROSES} FREE

\section{Crimson, Yellow, White, Yellow or Deep Crimson}

\section{Usually bloom first season. Bushes covered with Roses and bloom all Summer} choice.

Four Hardy Climbers-All bear profuse quantities of clustered roses like cut.

These Four splendid Climbers Free with each $\$ 2.00$ order for flower or garden seed.

One Rose Bush of this same kind free with each $50 \mathrm{c}$ order for flower or garden seeds. Take rour

Vake up rour own flower or garden seed orders now. If rou only need $50 \mathrm{c}$ worth of seeds then-get three of your friends to each select a $50 \mathrm{c}$ order from our catalogue-send these three orders with rour own order, and we will present to you absolutely free these four fine hardy climbing rose bushes.

These roses bloom constantly year after year, and are a continual pleasure.

Visit three of rour friends or neighbors- get them to send their flower and garden seed order with rours-and hare these magnificent ornaments for sour home, rou to pas not one cent for them.

If you want Roses that will gire sou constant pleasure from the dar ther are planted. we would urge that rou plant these famous rarieties. Thes bloom the first and erers rear from ear! $y$ Ias until serere freezing weather. We hare seen them unfold perfect flowers eren after a serere snow storm. There are other Roses as good, but certainls none better. Uneq ualed for porch ornamentation. Be sure to try theńs.

\section{HERE IS A DESCRIPTION OF EACH ROSE}

The Lincoln Yellow Rambler-The Ye $110 \mathrm{~m}$ Rambler has been found to successfully withstand without protection, a continued temperature of from zero to two degrees below. The flowers are borne in clusters, after the same manner as the Crimson Rambler. and are a bright lemon-sellow, changing to creams white.

The Lincoln Crimson Rambler-This wonderful climbing Rose, introduced some twelre rears ago, has made a record for itself unequalled br any other Rose. Every season it gains in popularits. It is a rigorous grower, making shoots 10 to 20 feet in height in a single season, and when in bloom commands admiration br the gorgeous displas of its brilliant crimson clusters of blossoms, each cluster a bouquet in itself. Lpwards of 15,000 blossoms hare been produced bs a single plant. This marrelous prodigalits is not unusual with it as it succeeds ererswhere. The blooms remain on the plant for a great length of time without losing their brightness; the foliage is also retained, to a great extent. during the winter. making the plant almost erergreen. It is perfectly hards in all parts of the countrs.

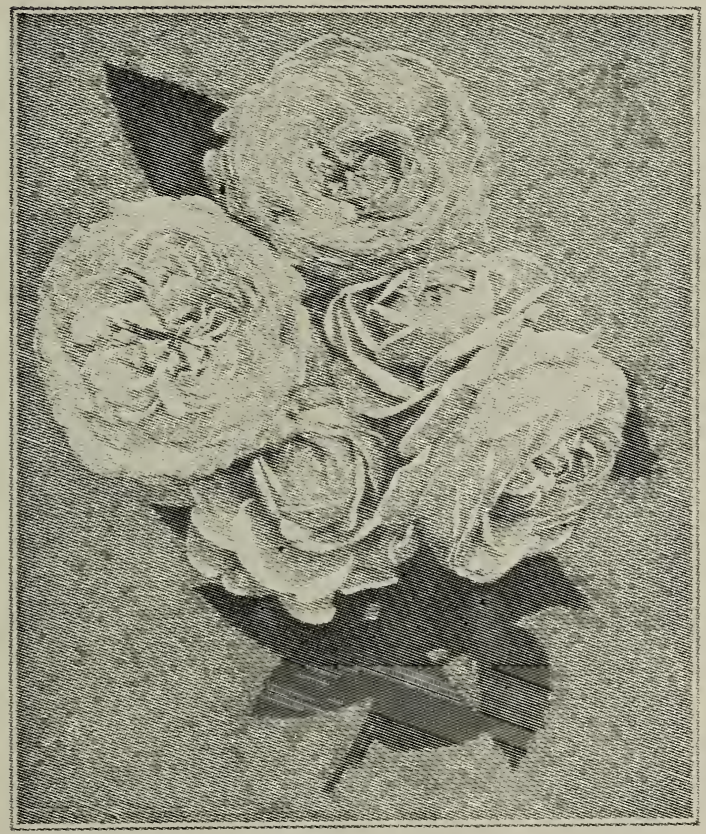

The Lincoln Deep Crimson Rambler-Pure deep crimson. A brighter. more intense color than the Crimson Rambler. which has heretofore been the standard for brilliant color; does not fade. bleach or wrash out. but holds its color to the last. Blooms two reeks earlier than the Crimson rambler. Flowers 21/ inches across and perfectls double, borne in large clusters. completels corering the ush.

The Lincoln Ye $110 \mathrm{w}$ White Rambler-A new vellowish rambler rose from Germans. Lnlike the other roses of this class it is of perpetua hlooming habit. While its heariest show of bloom is in the early summer, ret it also produces a considerable quantits of flowers all through the late summer and fall. Of rer rigorous habit of growti and absolutely hards Clean. glossr foliage, free from mildew or insect pests. Flowers are of good size, larger than most of the Rambler class. Color is a soft, creamr white, changing to pure white. but the rerr numerous and rather prominent rellow anthers gire quite a pronounced rellowish cast to the flowers.

Select your order at once. The seeds will keep just as well at your house as in our store rooms, and rose bushes will be sent you about the 10 th of April, or as soon as warm enough here.

We carefully select excellent plants for each customer. 


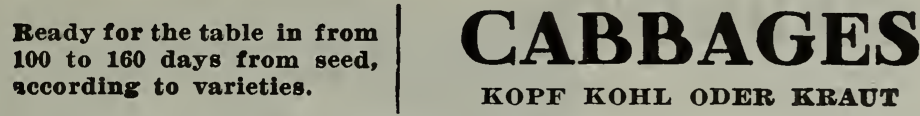

KOPF KOHL ODER KRAUT
1 ounce to 5,000 plants, 2 ounces to transplant for an acre.

For early summer use sow in hotbed in February or March. Before transplanting to the open ground they should be hardened off by exposing them gradually to the night air. For winter use sow in open ground in May or June, taking care in either case not to let the plants stand too closely, as this makes them "spindling." When five or six inches high, transplant in rows two feet apart one way, and 12 to 18 inches the other, according to variety, burying to the first leaf, whatever the stem length. Hoe frequently, drawing the earth up about the plants until they begin to head.

\section{EXTRA EARLY VARIETIES}

EARLY SPRING. The earliest, flat-headed variety. A wonderful compact plant with few outer leaves. Ready for use as soon as Early Jersey Wakefield. The head is oval and very large for the size of the plant, nearly equaling many of the later kinds. Pkt., 5c; 0z., 20c; 1/4 lb., 50c; lb., $\$ 1.60$; postpaid.

EXTRA EARLY EXPRESS. (Lightning.) Pointed, hard heads of good size; a week earlier than Jersey Wakefield. Pkt., 5̌c; oz., 20c; 1/4 lb., 50c; lb., \$1.60; postpaid.

EARLIEST ETAMPES. (Earliest of All.) Extremely early, with small, quite solid, pointed heads; excellent quality. Pkt., $5 c$; oz., 20 c ; $1 / 4$ lb., 50c; lb., $\$ 1.50$; postpaid.

EARLY YORK. Very early; small heart-shaped heads. Pkt., 5c; oz., 20c; $1 / 4$ lb., 50c; lb., $\$ 1.35$; postpaid.

EARLY JERSEY WAKEFIELD. Most gardeners depend upon it for the bulk of their extra early crop. Heads conical, very compact, solid and of excellent quality. Pkt., 5c; oz. 20c; $1 / 41 \mathrm{~b} ., 60 \mathrm{c} ; 1 \mathrm{~b} ., \$ 1.85 ;$ postpaid.

ARLY WINNIGSTADT. One of the best, being very hardy and sure to head; suffers less from the cabbage worm than any other sort; heads regular, conical, very hard and keep well. Pkt., 6e; oz., 20c; 1/4 lb., 50c; lb., $\$ 1.60$; postpaid.

\section{SECOND EARLY OR SUMMER VARIETIES}

EARLY DWARF FLAT DUTCH. An early cabbage of good size. Heads are flat and very solid. Pkt., 5c; oz., 20c; $1 / 4$ lb., 50c; lb., $\$ 1.50$; postpaid.

EARLY DRUMHEAD. A fine strain; of dark bluish-green color, plant very hardy; compact, flat head. Pkt., 5c; oz., 20c; $1 / 4$ lb., 50c; lb., \$1.50; postpaid.

FARLY SUMMER. A popular sort; producing large solid heads of fine quality; keeps longer

without bursting than most any sort. Pkt., 5c; oz., 20c; $1 / 4$ lb., 50c; 1b., $\$ 1.60$; postpaid.

ALL HEAD EARLY. The heads are deep through, extra solid, uniform in color, form and size. Pkt., 5c oz., 20c; 1/4 1b., 50c; 1b., \$1.60; postpaid.

ALL SEASON. (Vandergaw.) Growing so quickly the large, solid heads are very tender and of the finest quality. Pkt., 5c; oz., 20c; $1 / 1$ lb., 50c; lb., $\$ 1.60$; postpaid.

\section{LATE OR WINTER VARIETIES}

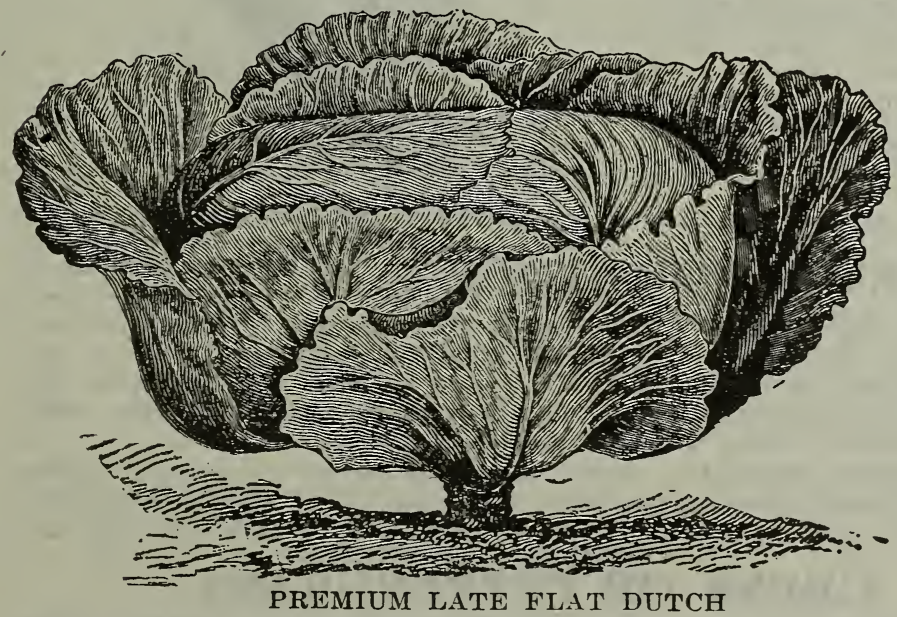

SUREHEAD. This cabbage never fails to make a fine, solid, large head, with few outer leaves. It is a vigorous grower, maturing late. First-class main crop variety. Pkt., Бc; oz., 20c; 1/4 lb., 50c; lb., \$1.50; postpaid.

THE LUPTON. This variety is one of the best for main crop, com. bining the best qualities of the second-early and the late sorts. It is also one of the best keepers. Pkt., 5c oz., 25c; 1/4 lb., 70c; lb., $\$ 2.00$; postpaid.

PREMIUM LATE FLAT DUTCH (Selected strain). The great cabbage for fall and winter. The large, oval, solid heads are flattened and of splendid quality. Will keep in the best condition for a long time. Pkt., 5c; oz., 20c: $1 / 4$ lb., 50c; lb., $\$ 1.50$; postpaid.

LARGE LATE DRUMHEAD. A favorite winter variety; extra large, solid heads; slightly later than the Flat Dutch. Pkt., 5c; oz., 20c; 1/4 lb., 50c lb., \$1.50; postpaid.

AUTUMN KING. Are extremely large and solid. Flat headed late variety. The plant is of extra strong growth, with dark bluish-green leaves. Splenuid winter variety. Pkt., 5c oz., 25c; 1/4 Ib. 70c: lb.. $\$ 2.00$; postpair.
HOLLANDER (Danish Ball Head). Hardest heading variety known. Remarkable for great weight and long-keeping qualities. The heads are of medium size, exceedingly tender, crisp, solid, with no waste heart. Pkt., 5c; oz., 25c; $1 / 4$ lb., 80c; Ib., $\$ 2.60$; postpaid.

RED DUTCH. A deep red or purple, solid head, flne for salad or pickling. Pkt., 5c oz., 20c; $1 / 4$ lb., 50c; lb., $\$ 1.50$; postpaid. 


\begin{abstract}
Ready for table in from 95 to 120 days from seed, according to variety.
\end{abstract}

\section{CARROTS}

CARROTTEN MOHREN
1 oz. to row 100 feet long. $21 / 2$ lbs. per acre.

Any good land, if thoroughly and deeply worked, will produce satisfactory crops. Sow as early as the ground can be worked, sow the smaller kinds in rows 16 to 18 inches apart. For field culture sow in drills 18 to 24 inches apart. Cover one-half to one inch deep and see that the soil is pressed firmly above the seed. Do not let the weeds get a start. Thin to three to six inches apart in the rows as soon as the plants are large enough. For winter use gather and store like turnips.

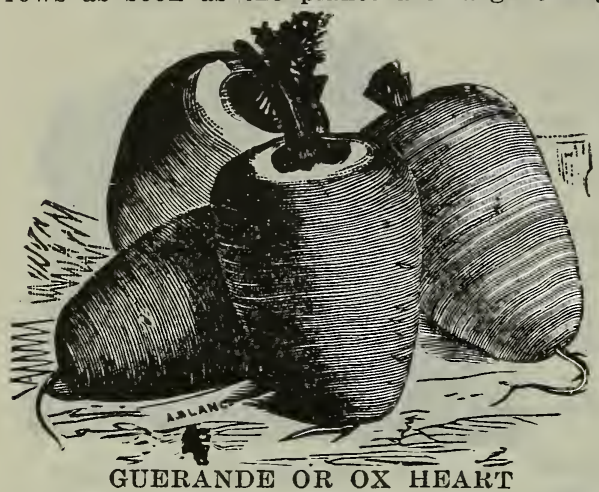

Price of all Carrots: Pkt., 5c; oz, 15c;

$1 / 4$ lb., 40c; lb., \$1.00.

HALF LONG SCARLET NANTES. The leaves are fine, the roots are almost cylindrical, very smooth, of good shape and size, and atout six. inches long; the flesh is red and very sweet. They are easily pulled and keep well. A most excellent sort.

HALF LONG STUMP ROOT.. The tops are of medium size, roots deep orange, large, tapering to a dull point. Smooth, crisp and tender.

IMPROVED LONG ORANGE. Large, smooth, and of rich orange color. A good keeper, of fine quality for table use, and highly nutritious for stock.

THREE GOOD Books
Amateur Fruit Growing, by Samuel B. Green.
A practical guide to the growing of fruit for home
use and the marke,, written with special refer-
ence to a cold climate. Illustrated. 134 pp., price,
12 mo. cloth, 50c; paper 25c.
Vegetable Gardening, by Samuel B. Green, 10th edi-
tion. A manual on the growing of vegetables for
home use and market. Profusely illustrated. 252
pages, price, 12 mo. cloth, \$1.00; paper, 50c.
Weeds and How to Eradicate them, by Thomas
Shaw. Giving the names of the most troublesome
weed pests east and west and successful methods
of destroying them. Price, 16 mo. cloth, 210 pp.,
50c; paper, 25c.

\section{SOW IN APRT OR MAY CARROTS FOR STOCK}

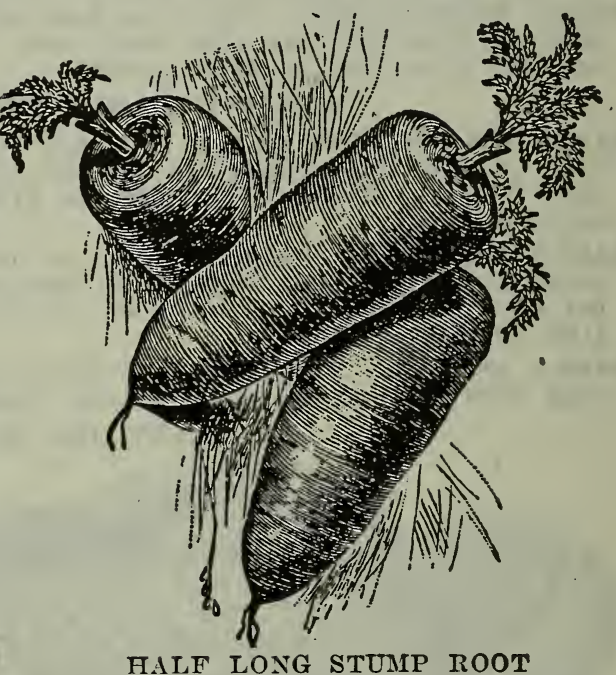

These are undoubtedly the most valuable of all the roots usually grown for stock. They are more nutritious than turnips and nearly all animals like them and are benefited by them.

LARGE YELLOW or VICTORIA. Largest, heaviest cropping and most nutritious variety in cultivation; roots fine, of light orange color, and possessing high feeding properties; good keeper. Pkt., 5c; oz., 10c; 1/4 lb., 20c; lb., 60c; postpaid. 5 lb., $\$ 2.25$, by express.

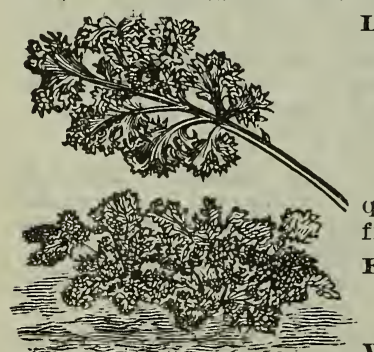

LARGE WHITE BELGIAN. Grows one-third out of the ground. Roots pure white, green above ground with small top. Flesh rather coarse. The roots grow to a large size. Pkt., 5c; oz., 10c; 1/4 1b., 20c; lb., 60; postpaid.

\section{CRESS OR PEPPERGRASS}

Ready in from 21 to 40 days. Cress should be sown in a sheltered spot quite thick in shallow drills, in a short time it will be fit for cutting. Sow frequently as it matures very rapidly.

EXTRA CURLED. This small salad is much used with lettuce. The warm, pungent taste makes a most agreeable addition. Pkt., 5c; oz., 10c; 1/4 lb., 25c; postpaid.

WATER CRESS. Hardy, perennial, growing readily on the banks of CRESS OR PEPPERGRASS streams or ponds. Pkt., 5c; 1/2 oz., 20c; oz., 30c; postpaid. 


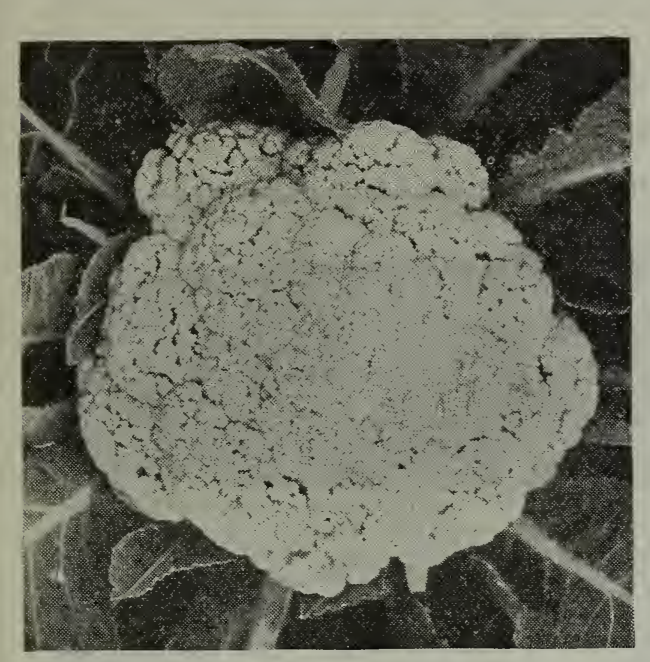

\section{Cauliflower}

BLUMEN KOHL

(For Cauliflower plants see page 14.)

These need a deep, rich, moist soil, and require the same treatment as cabbages. For early summer varieties, seed should be sown in hotbed early in March, transplant when weather is warm. For late or autumn varieties, sow in March or April, transplant in June; hoe often.

EXTRA EARLY ERFURT. Head of good size, white and compact. Early and desirable. Plit., $5 c ; 1 / 2$ oz., $90 \mathrm{c} ;$ oz., $\$ 1.60 ;$ postpaid.

EARLY SNOWBALL. (Extra Selected.) This very superior strain is noted for producing early plants of dwarf habit, short, compact growth, and uniform shape. It is extremely hardly and one of the surest to make a solic head. For forcing or planting in open ground no other variety can surpass it. noorl for early. second early, and late planting. Plit., 5c; 1/2 oz., $\$ 1.35 ;$ oz.. $\$ 2.50$; postpaid.

1 ounce to 3,000
plants or 200 feet
of drill.

Grow your orn Celery. (For Celery Plants see page 14.)

Sow the seed (which is slow to germinate) in shallow boxes, or hotbed, corer the seed not too deep. Keep the bed moist, almost wet until the seeds germinate. When about two inches deep, thin out and trapsplant so that they may stand three inches apart, when the plants are four inches high, cut off the tops, which will cause them to grow stocky. The essentials to success in celery growing are rich soil and pleuty of water. The best results are usually obtained from setting avout the middle of June or the first of July. In setting, prepare broad trenches about six inches deep and four to six feet apart, in which the plants should be set six inches apart, cutting off the outer leares and pressing the soil firmly about the roots. Cultivate freely. Earth up a little during the summer, keeping the leaf stalks close toge:'?r, so that soil cannot get between them. Finish earthing up in autnrnn, and never hoe or earth up when plants are wet, as this would he likelj to cause them to rust or rot.

ro keep celery for winter, dig trenches a foot wide and as deep as the tops of the plants. Stand celery in these erect, with what dirt adieres to the roots, packing closely, but not crowding. It should be coiered with straw or leaves a little at a time, as the cold becomes greater. Celery will bear a good deal of frost.

GIANT PASCAL. One of the best for fall and winter use. The stalis are very large, solid, crisp and of rich, nutty flavor. It blanches very easily and quickly. The heart is golden yellow, very attractive. Pkt., 5c; oz., 20c; 1/4 lb., 50c; postpaid.

CELERIAC GIANT PRAGUE. The roots of this celery are turnip-shaped, large and smooth; are almost round and with a very few side roots. Sweet and tender and may be cooked like turnips or eaten like radishes; used largely for seasoning meats and soups. Pkt., 5c; oz., 20c; $1 / 4$ lb., 50c; postpaid.

GOLDEN SELF-BLANCHING. This is without doubt the best celery for general use, the ribs are perfectly solid, crisp, brittle and of delicious flavor, while it has the decided merit of being self-blanching to a very remarkable degree. The heart is large, solid and a beautiful rich, golden vellow. It is decidedly the best keeper, of all the self-blanching varieties. Pkt.. 5c; oz., 25c; 1/4 Ib., 90c; postpaid.

GIANT GOLDEN HEART. This variety attains a large size, but still remains crisp and tender. It is a fine keeper and a favorite for market. Pkt., 5c; oz., 20c; 1/4 lb., 45c; postpaid.

SNOW WHITE. A pure white variety. It is vigorous in growth, rich in flavor and crisp; grows solid on all kinds of soil, and is an ex. cellent keeper. Pkt., 5c; oz., 20c; 1/4 1b., 60c; postpaid.

WHITE PLUME. (See cut.) A variety specially adapted to cultivation by amateurs, as its inner stalks and lesves are uaturally white. Br simply tying up the stalks and drawing up the soil with the hoe the work of blanching is complete. It is tender, crisp and of good flavor. The earliest celery in cultivation, but will not keep longer than Christmas. Pkt., 5c; oz., 20c; $1 / 4$ lb., 50c; postpaid.

\section{Chives}

CHIVES (Schnittlouch.) A perfectly hardy plant something like an onion. Tops are cut off from time to time and used to flavor soup. Seed: Pkt., 10c. Clumps, each, 10c: per doz. $\$ 1.00$. Postpaid. 


\section{CORN--Sweet or Sugar}

TOCKER MAIS

For prices in larger lots see our Market Gardeners' Price List. Sent Free

1 quart to 200 hills; 8 to 10 quarts to the acre. In an average season from planting to first fair picking is from 55 to 85 days, according to variety.

Sweet corn being liable to rot in cold, wet ground, should not be planted before May, or until the ground has become warm; practically nothing is gained in time, and much is lost in quality by planting too soon. To have the finest sweet corn it must be picked in just the right condition, that is when the skin of the grain breaks at the slightest punctures, and planting could be made every two weeks to have a supply at this stage. Plant in rich ground in hills three feet apart each way, covering about half an inch, and thin out to three plants to a hill. The extra early varieties can be planted closer. Give frequent and thorough but shallow cultivation until the tassels appear.

If sent by express at buyer's expense, 5c per pint or $10 \mathrm{c}$ per quart may be deducted.

PEEP O' DAY. The two points of this new corn are its extraordinary earliness and sweetness. It is also very productive, the stalks bearing from two to five ears each, are very dwarf, which admits of their being planted close together. Pkt., 5c; pt., 15c; qt., 30c; 2 qts., 55c; postpaid.

EARLY EVERGREEN. Very similar to Stowell's Evergreen; somewhat smaller; ripens about ten days earlier. Pkt., 5c; pt., 15c; qt., 30c; 2 qts., 55c; postpaid.

HOWLING MOB. Extra sweet, about five days later than Early Cory. Ears have 12 to 14 rows and are 5 to 9 inches long. Usually two to a stalk. The heary husk extends well out from the top, protecting it from green worms. Pkt., 5c; pt., 25c; qt., 45c; postpaid.

EXTRA EARLY PREMo. A real Sweet Corn as early as Extra Early Adams. Large, sweet and tender. Plant early, as it will stand some frost. Pkt.. 5c; pt., 20c; qt., 35c; postpaid.

MAMMOTH WHITE CORY. Nearly as early but larger than Early Cory. The ears are twelverowed; grains are broad, very white and of excellent quality for an early sort. Pkt., 5c; pt., 15c; qt., 30c; 2 qts., 50c; postpaid.

CROSBY'S EARLY. Remarkably early and of the best flavor. Ears of medium size, twelverowed, with grains very tender and sweet. Pkt. 5c; pt., 15c; qt., 30c; 2 qts., 50c; postpaid.

EARLY CHAMPION. Only a few days later than the extra earlies, bearing large, handsome twelve-rowed ears. Deep, white, plump grains of milky tenderness and very sweet. Very productive. Pkt., 5c; pt., 15c; qt., 30c; 2 qts., 50c: postpaid.

GOLDEN BANTAM. Extremely hardy, can be planted earlier than any other true sweet corn, thus producing the earliest supply. Ears 6 Inches long, with 8 rows of grains, which are a golden yellow when ready for use. Can be planted thickly, and every stalk should have from 2 to 3 perfect ears. Plt., 5c; pt., 15c; qt.. 30c; 2 qts., 55c; postpaid.

gTOWELL'S EVERGREEN. The standard main crop variety. It is hardy, large-growing and productive, very tender and sugary, remaining a long time in condition suitable for boiling. Pkt., 5c; pt., 15c; qt., 30c; 2 qts., 50c; postpaid.
EARLY MINNESOTA. One of the best early sort for the market or private garden. Stalks four to five feet high and bearing one to two long eight-rowed ears; kernels very broad, sweet and tender, not shrinking much in drying. Pkt., 5c; pt., 15c; qt., 30c; 2 qt., 50c; postpaid.

BLACK MEXICAN. Medium early, about six feet in height, with one or two fine ears eight inches in length, with eight rows of large grains, which when in condition for the table cook remarkably white, but the ripe grain is black or bluish-black. It is surpassed by none in tenderness. Pkt., 5c; pt., 15c; qt., 30c; 2 qt., 55c; postpaid.

Country gentreman. (Shoe Peg.) This variety has a small cob densely covered with irregular rows of very long, slender grains of fine quality. Pkt., 5c; pt., 15c; qt., 30c; 2 qts., 55c; postpaid.

MAMмоTH SUGAR. Produces the largest ears of any sort; excellent quality, sweet, tender and delicious; late variety. Pkt., 5c; pt., 15c; qt., $30 \mathrm{c} ; 2$ qts., 50c; postpaid.

\section{POPCORN}

WHITE RICE. A prolific variety. Ears short; kernels long, pointed and white. Probably no variety of pop corn is superior to this for parching. Pkt., 5c;1b., 20c; postpaid.

QUEEN'S GOLDEN. The largest of all Pop Corns. The stalk grows five to six feet high, and bears two or three large ears each. It is yellow, but pops creamy white, and of excellent quality. Pkt., 5c; lb., 20c; postpaid.

Ask for prices on Pop Corn in large lots.

\section{CORN SALAD}

(Feldsalat.) A small, hardy plant, used during the winter and spring months as a substitute for lettuce; also cooked like spinach. Pkt., 5c; o7., 10c; $1 / 4$ 1b., 25c; postpaid.

Morgan County Colo., Febr. 6, 1912.

I am so pleased with the seeds you sent me that $I$ advocated them to $\mathrm{my}$ neighbors and they asked me to send in their names and would like catalogs. MRS. JOE BEUTTLFR. 


\section{CUCUMBERS \\ GUERREN}

$1 \mathrm{oz}$. to 50 hills; 2 to 3 lbs. to the acre.

Earliest varieties ready for table use in 50 to 55

days from seed. Main crop in 65 to 75 days.

As soon as the weather becomes settled and warm, plant in hills 4 to 6 feet apart each way, with 8 or 10 seeds in a hill; cover half an inch deep, smoothing the hill off with the hoe. Keep the soil well stirred, and when the plants are out of danger of insects, leave 3 or 4 plants to a hill. For pickles, plant from 1st of June to 1st of August. The fruit should be gathered when large enough, whether required for use or not, as, if left to ripen on the vines, it destroys their productireness. A few hills for early use may be had by sowing on pieces of sod in a hotbed, and when warm enough transplant to open ground.

A GOOD SCHEME. Put in a second row of seed a few inches from your first cucumbers when they begin to run. The bugs prefer young plants. Your earliest plants are thus protected and those of later planting that escape the bugs will prolong the pickle season.

DAVIS PERFECT. This Cucumber has the merit of being not only a first-class rariety for forcing under glass, but is equally as good for outdoor culture. The color is a dark, glossy green; in shape it is smooth and symmetrical with an average length of ten to twelve inches. It is rery tender and of exceptionally good flavor. For shipping it is unsurpassed, Pkt., 5c; oz., 10c; 1/4 1b., 30c; 1b., $\$ 1.00$; postpaid.

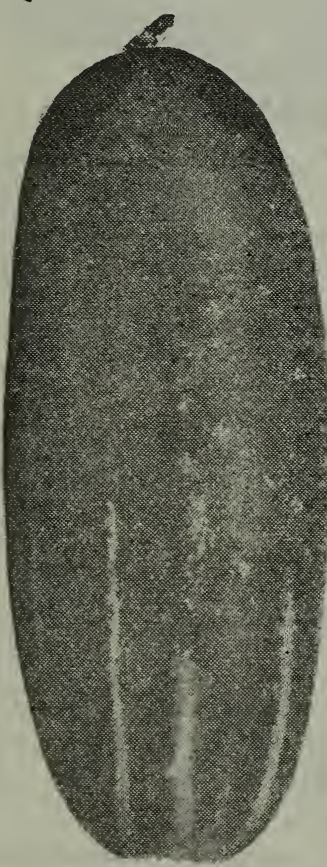

WHITE SPINE

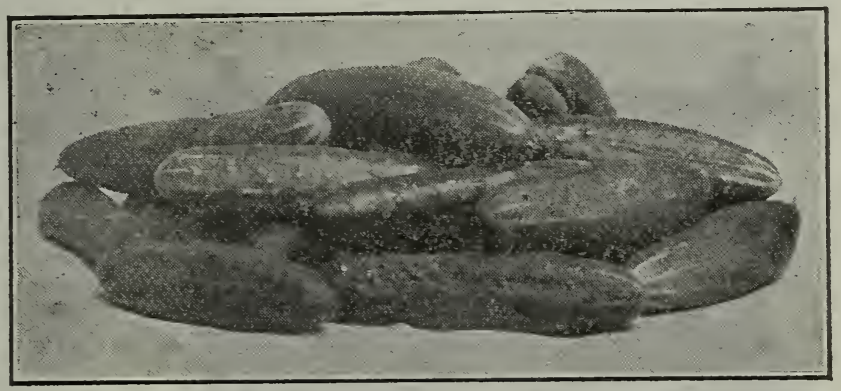

DAVIS NEW PERFECT CUCUMBER (FIELD RUN)

EARLY CLUSTER. A short, pale green variety; fruit borne in clusters near the root, containing few seeds. Pkt.. 5c; oz., 10c; 1/4 1b., 30c; 1b., 90c; postpaid.

EARLY FRAME OR SHORT GREEN. Excellent for table use and for pickling. Fruit straight, smaller at each end; bright green, flesh tender and crisp. Pkt., 5c; oz., 10c; 1/4 1b., 30c; lb., 90c; postpaid.

IMPROVED EARLY WHITE SPINE. (See cut.) For forcing it is preferred to all others. Flesh tender and crisp. Fruit uniform in size, straight and light green, with a few white spines. Pkt., 5c; 0z., 10c; 1/4 lb., 30c; lb., 90c; postpaid.

BOSTON PICKLING or GREEN PROLIFIC. One of the best pickling varieties; dark green, tender, crisp, and productive. Pkt., 5c; oz., 10c ; $1 / 4$ lb., 30c; lb., 90c; postpaid.

IMPROVED JERSEY PICKLING. A standard small variety, dark green, tender, crisp, productire, of fine flavor and uniform size. Plkt., 5c; oz., $10 \mathrm{c} ; 1 / 4$ 1b., 30c; 1b., 90c; postpaid.

IMPROVED LONG GREEN. A well known standard, main crop variety, about nine inches long, of excellent quality, and makes the best of pickles. Vines vigorous and very productive. Plst., 5c; $0 \mathrm{z} ., 10 \mathrm{c} ; 1 / 4 \mathrm{lb}$., 30c; lb., 90c; postpaid.

JAPANESE CLIMBING. The rines can be trained to climb, thus requiring less ground space. The cucumbers are thick, tender, and of delicate flavor, flesh white; skin dark green, turning to brown and netted when ripe. Pkt., 5c; oz., 10c; $1 / 4$ 1b., 30c; lb., $\$ 1.00$; postpaid.

EVERBEARING. Small, rery early and productive; solid, few seeds and of fine quality. It continues to bear until frost. Pkt., 5c; oz., 10c; 1/4 lb., 30c; lb., 90c; postpaid.

NEIF ENGLISH FORCING (Rochfords). They grow 15 inches long under glass. Pkt., 10 seeds, 10c; 125 seeds, $\$ 1.00$.

\section{EGG PLANT}

\section{GLERTLANZE}

1 oz. to 1,000 plants. Ready for table in 145 to 160 days.

A tender plant, start early in hotbed or in the house. Plant out earls in June, care being necessary to prerent plants being chilled by the change.

MPROVED NEW YORK PURPLE, SPINELESS. The standard for home and market. Fruit very large, productive and of the highest quality. Pkt., 5c; 1/2 oz., 25c; oz., 40c; $1 / 4 \mathrm{lb}$., $\$ 1.25$; postpaid.

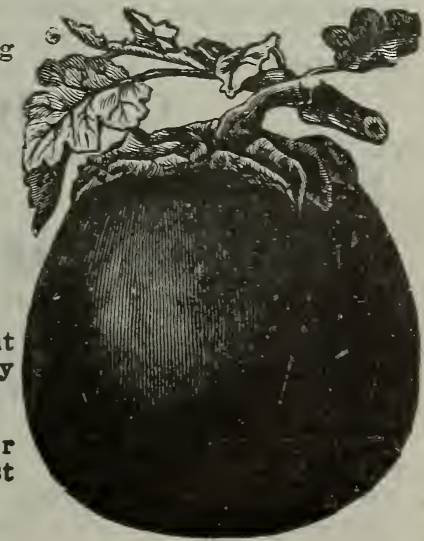




\section{ENDIVE \\ ENDIVIEN}

Ready for table in 43 to 50 days from seed. 1 oz. to 100 feet of drill. One of the best autumn and winter salads. Sow from June until August, $1 / 2$ inch deep in drills 14 inches apart and thin out to 1 foot apart in rows. When nearly full grown bleach by tying the tips of the leaves together.

GREEN CURLED. Large and well adapted to this soil and climate. Pkt., 5c; oz., 15c; $1 / 41 \mathrm{lb}$., $40 \mathrm{c}$; postpaid.

MOSS CURLED. Leaves very finely curled. Pkt., $5 \mathrm{c} ;$ oz., 15c; 1/4 lb., 40c; postpaid.

WHITE CURLED. Very tender when cut young; blanches readily. Pkt., $5 \mathrm{c}$; oz., 15c; $1 / 4 \mathrm{lb} ., 40 \mathrm{c}$; postpaid.

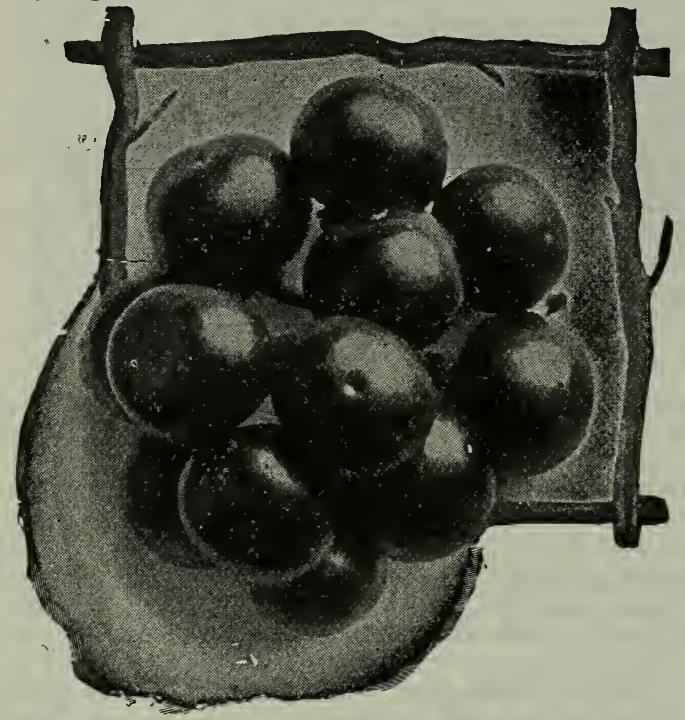

\section{GARDEN HUCKLEBERRY}

A New, Heavy Yielding Garden Berry

We could not supply the demand for these last year. Send your order early.

This new fruit can be grown from the seed the first year and produces about as large as a grape; the color is jet black, and when cooked can scarcely be discerned from the real huckleberry. Plant and cultivate same as tomatoes. Do not eat green. Berries make splendid pies, jelly and sauce. Parboil a few minutes in soda water, using about 1 teasponn soda to $1 \mathrm{lb}$. of fruit. After pouring off this water add sugar and cook slowly for several hours; a little vinegar or lemon juice improves the flavor. Very desirable while waiting several years for hardy fruits to come into bearing, or in dry climates where the ordinary small fruits do not succeed. Pkt., 5c; oz., 20c.

\section{GARLIC}

The sets should be planted in spring. Cultivate same as onions. Sets, per oz., ว̌c; 1/4 lb., 15c; 1b., 40c; postpaid.

\section{KALE or BORECOLE}

\section{BLAETTER KOHI}

Ready for table in 100 to 130 days.

$1 \mathrm{oz}$. to 300 feet of drill, and makes 5,000 plants. Sow about April 15 in well prepared soil, covering the seeds thinly. Cultivate like cabbage. Much improved by freezing.

TALL GREEN CURLED. About two feet high with numerous dark green curled leaves. Pkt., 5c; oz., 10c; 1/4 1b., 25c; postpaid.
DWARF GERMAN. (German Greens.) 'The leaves are curly, bright green, very tender, and delicate flaror. Pkt., 5c; oz., 10c; 1/4 lb., 25c; postpaid.

\section{KOHLRABI}

\section{KOHLRABI}

1 oz. to $300 \mathrm{ft}$. drill and makes 3,000 plants. A vegetable intermediate between the cabbage and turnip. The edible bulb is served like turnip. Sow from May to July in rows 18 inches apart, and thin. Cultivate the same as cabbage.

EA R I I E S T S H O T LEAVED WHITE VIENNA FROCING. This variety is especially adapted for early work and forcing; delicate flavor, flesh white and very tender. Pkt., 5c; oz., 25c; 1/4 1b., 75̃c; postpaid.

EARLY WHITE VIENNA. A favorite sort; flesh white and tender. Pkt., 5c; oz., 20c; 1/4 lb., 50c; postpaid.

EARLY PURPLE. Purple outside with white flesh. Pkt., 5c; oz., 20c; $1 / 4$ lb., 50c; 1b.. \$1.75; postpaid.

\section{HERBS}

Herbs delight in a rich, mellow soil. Those marked with a * are perennial. Sow early in spring in shallow drills, one foot apart; when up a few inches thin out; cut just before they come into full blossom, tie in bunches and hang up or spread thinly.

DILL. Leaves and seed are used in soups, sauces and pickles. It reseeds itself each year. Pkt., 5c; oz., 10c; 1/4 lb., 20c; postpaid.

*LAVENDER. (Lavendel.) Aromatic, medicinal herb. Pkt., 5c; oz., 20c; 1/4 lb., 60c; postpaid.

*MARJORAM, SWEE'T. (Majoran.) Leaves and shoots for seasoning. Pkt., 5c; oz., 20c; $1 / 4 \mathrm{lb}$., ific; postpaid.

*SAGE. (Salbei.) Most useful herb for seasoning. Pkt., 5c; 0z., 15c; $1 / 4$ lb., 40c; postpaid.

SUMMER SAVORY. (Bohnenkraut.) Used for flavoring soups. Pkt., 5c; oz., 15c; $1 / 4$ lb., 40c; postpaid.

-THYME. (Thymian.) For medicinal use. Pkt., 5c; 0z., 50c; $1 / 4$ lb., $\$ 1.50$; postpaid.

\section{LEEK}

\section{LAUCH}

$1 \mathrm{oz}$. to 100 feet of drill, and makes 1,500 plants. Succeeds best in light, rich soil. Sow early in drills 1 inch deep and 1 foot apart. When 6 inches high, transplant in rows 10 Inches apart each way, as deep as possible, that the neck may be bleached.

AMIERICAN FLAG. An old favorite: Large with broad leaves growing only on two sides; enormous size; best for forcing; excellent keeper. Pkt., 5c; oz., 15c; $1 / 4$ lb., 40c; postpaid.

AMERICAN FLAG

\section{MINT}

The old-fashioned mint has been growing in favor of late years. Used in flaroring meats. etc., also for mint sauce. Easily grown. We offer only the roots. Per clump, 15c; 2 for $25 \mathrm{c}$; 
Fit for use in 3 or 4 weeks, marketable size, 60 to 75 days from seed.

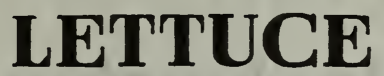

LATTICH SALAT
1 OUNCE TO 400

FEET OF DRILI.

Lettuce thrives best in a light, rery rich, moist soil, but does well in common garden soil en. riched with rotten manure. For first crop sow in gentle heat in February, and transplant to 10 inches apart. It may be sown thickly and cut when plants are very young. For a summer supply sow thinly in shallow drills in a cool, partially shaded place, in rich soil, and thin out to a foot apart.

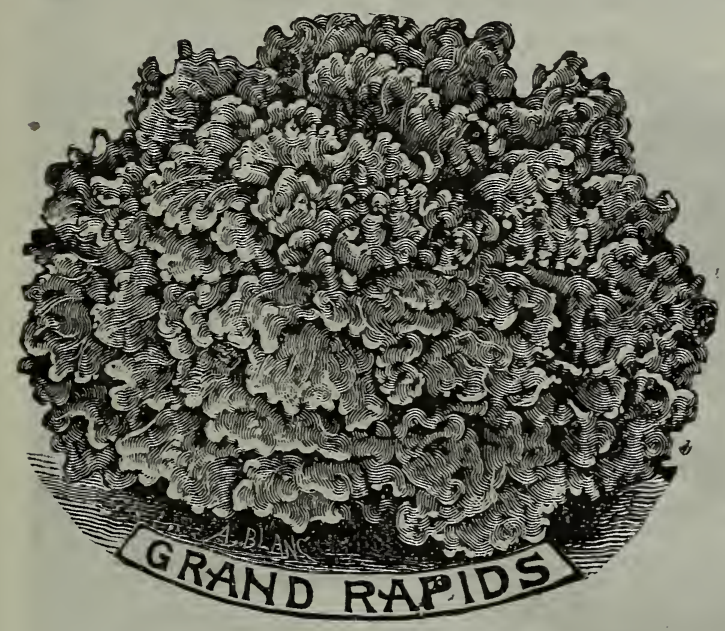

CLRLED OR LOOSE-LEAVED VARIETIES

EARLY CURLED SILESIA. An early, erect growing and loose heading lettuce, especially adapted for outdoor planting, and can be used when rery young. Exceedingly sweet and well flavored. Pkt., 5c; oz., 10c; $1 / 4$ lb., 30c; lb., SOc; postpaid.

\section{CABBAGE OR HEADING VARIETIES}

The best results with head or cabbage sorts is only obtained when the plants are transplanted several times.

HANSON. Forms a large, flat head, resembling that of cabbage and so slow to form a seed stalk that it often fails to seed at all. Very tender and sweet. A standard summer heading lettuce. Pkt., 5̃c; oz., 10c; 1/4lb., 30c; 1b., 85c; postpaid.

DENVER MARKET. An early variety of Head Lettuce, either for forcing or open ground. It forms large heads, of good light green color. The leares are blistered (like the Savoy Cabbage), rers crisp and tender. Pkt., 5c; oz., 10c; 1/4 lb., 30c; lb., S0c; postpaid.

ICEBERG. Makes a large, handsome, crisp head, conical in shape, tightly folded and well blanched; outer leares fringed. Very highly esteemed for its beautiful appearance and mild flaror, eren during hot summer months. Pkt., эc; oz., 10c; 1/4 lb., 30c; lb., 90c; postpaid. forcing, this variets undoubtedly stands at the
head of the list, being of quick growth, little liable to rot and standing for some days after being fit to cut. The plant is upright and forms a loose cluster of large, light leares: It is useful also for outdoor planting. Pkt., כ̌c; oz., 10c; $1 / 4$ lb., 30c; lb., 90c; postpaid.

SIMPSON'S EARLY CURLED. Leares broar, firilled and blistered. Light green. sweet, tender. and well flavored. An early, erect growing sort. Pkt., 5c; oz., 10c; $1 / 4$ lb., 30c; lb., 80c; postpaid.

BLACK SEEDED SIMPSON. The leaves are large and form a compact mass. They are thin, tender and of a very light green color. Well adapted for growing under glass or for rer 5 early spring use. Pkt., $5 \mathrm{c} ;$ oz., $10 \mathrm{c} ; 1 / 4 \mathrm{lb}$. $30 c$; lb.. S5c; postpaid.

EARLY PRIZE HEAD. Forms a mammoth plant. in which even the outer leaves are crisp and tender; color bright green tinged with brownish red. It is of superb flaror and very hardy. Pkt., 5c; oz., 10c; 1/1 lb., 30e; lb., S5̌c; pustpaid.

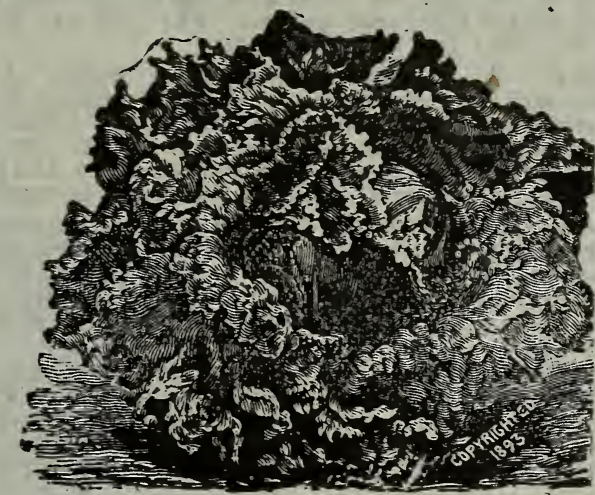

ICEBERG

\section{Mustard 102, to 0 s feet of orill}

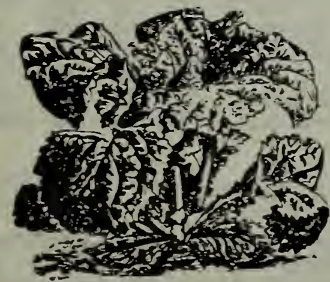

Verr hardr. Seed can be sown as soon as the soil is free from frost, in shallow drills. Cut when a few inches high. It grows rapidly, and sereral sowings may be made.

CHINESE. The immense leares grow rapidls. and can be cut frequently until killed by frost. Leares are eaten boiled like spinach. Pkt., 5c; oz., 10c; 1/4 lb., 25c; lb., 75c; postpaid.

MAMMOTH SOUTHERN CURLED. The large curled-leaf rariety, popular in the South, where the seed is sown in the fall for spring use. Pkt., 5̌c; oz., 10c; 1/4 lb., 25c; 1b.. 75c; postpaid.

WHITE. A small pungent salad; the seed is also used for flaroring pickles, etc. Pkt., 5c; oz., 10c; $1 / 1 \pm$ lb., 20c; 1b., 55c; postpaid. 
Earliest varieties ready in 90 to 100 days from sowing. General crop requires 115. to $140^{\circ}$ days.

\section{Muskmelons}

ONE OUNCE TO 50

HLLS: 2 TO 3 POUNDS

PER ACRE.

Melons thrive best in a light rich soll. Plant when the ground has become warm and dry, and danger from frost is past, in hills 6 feet apart each way in well enriched soil 12 to 15 seeds in each hill. After all danger of bugs is over thin out to 3 plants per hill. When about three feet long, pinch off the tips to make them branch, and the fruit mature earlier. G. Green Flesh. S. Salmon Colored Flesh. Y. Yellow Flesh.

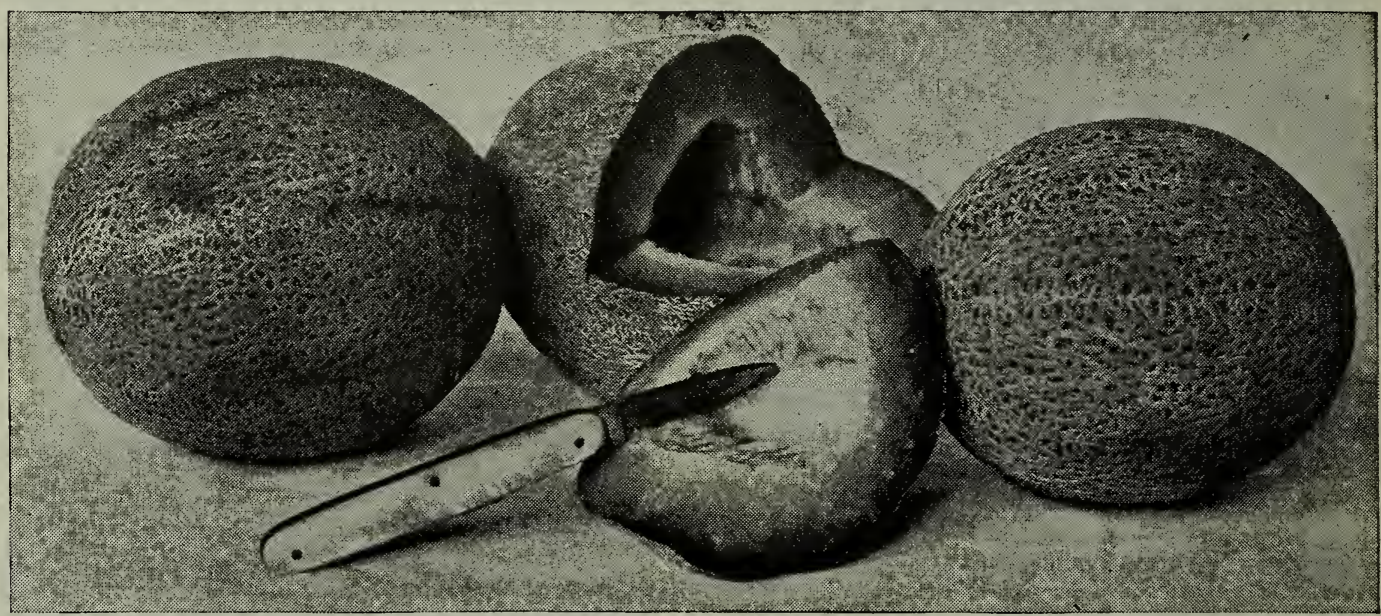

ROCKY FORD... G. A small oval melon, slightly ribbed and covered with a coarse netting. The flesh is thick, green, very sweet and juicy, and solid clear to the rind; very early and popular. One of the best for hotel and restaurant use, as well as for the home garden. Pkt., 5c; oz., 10c; * Ib., 25c; 1b., 60c: postpaid.

GRAND. S. A most excellent new melon of a peculiar rich green color, slightly ribbed and netted. Has uniformly rich, thick, salmoncolored flesh of most excellent flavor. It is from ten to fourteen days earlier than Osage. Pkt., 5c; oz., 10c; $1 / 4$ lb., 35c; 1b., $\$ 1.00$; postpald.

OSAGE, OR MULLER'S CREAM. S. A standard sort, medium size, oval, dark green, netted, and slightly ribbed. The flesh is thick, and firm, rich salmon, highly flavored and delicious to the rind. Pkt., 5c; oz., 10c; $1 / 1$ lb., 30c; lb., \$1.00; postpald.

EMERALD GEM. Y. A small, very early melon, form globular: skin smooth, dark green. The ribs are marked, flesh very thick, with small seed cavity, and the flavor is sweet and luscious. Plt., 5c; 0z., 10c; 1/4 1b., 30c; lb., $\$ 1.00$; postpaid.

HOODO0. S. A new early orange flesh variety of oval shape and uniform in size. The flesh is very thick, of flne grain and sweetest finvor: a heavy yielder. Somewhat resembles Rocky Ford. Splendid shape for serving in halven. The rind being very tough makes it a good shipper. Plst., 5c; oz., 15c; $1 / 4$ lb., 35c; lb., \$1.00.

BURRELL'S GEM. S. Very much like the Rocky Ford, but has orange colored flesh. The flesh in fine grained and spicy. It is a good keeper. Fruits large and somewhat elongated. Pkt., 5c: oz., 10c; $1 / 4$ lb., 25c; 1 b., 85c; postpaid.

TIP TOP. Y. Every fruit produced, whether big or little, early or late in the season, is a good one-sweet, juicy and fine flavor, firm, but not hard fleshed, eatable to the very outside coating. As a yielder it is not surpassed. Pkt., 5c; oz., 10c ; $1 / 4$ lb., 30c; lb., \$1.00; postpaid.

LONG ISLAND BEAUTY. G. Fruits of large size, well flattened, heavily ribbed and netted. of very handsome appearance, and fine qualit Most highly recommended. It ripens as early and is similar to Hackensack, but superior. Pkt., 5c; oz.. 10c; 1/4 1b., 25c; 1b., 85c; postpaid.

All Postpaid pkt. oz. 1/4lb. $1 \mathrm{~b}$.

PAUL Rose, or PETRosky. S. Small, oval, highly flavored and very sweet.......\$.05 $\$ .10 \$ .30 \$ 1.00$ CHICAGO MARKET. G. Early, large, nearly round, small seed cavity, delicious .05 .10 .25 .75 EXTRA EARL Y HACKENSACK. G. Like Hackensack but about ten days earlier.... $.05 \quad .10 \quad .25 \quad .76$ HACKENSACK, TURK'S CAP. G. Large, round, fiattened ; deep, wide ribs........... $.05 \quad .10 \quad .25 \quad .75$

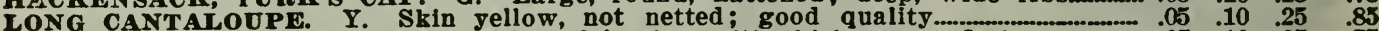

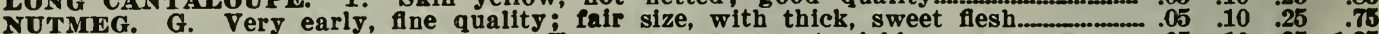
VINE PEACH, VEGETABLE MELON. For preserves, sweet pickles, mangoes........... $.05 \quad .10 \quad .351 .25$

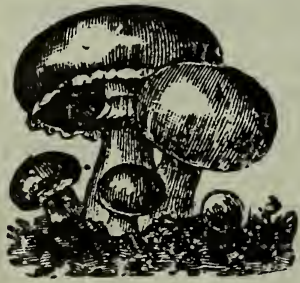

\section{Mushroom Spawn}

AMERICAN, PURE CULTURE SPAWN. Produced by the new graftin: process, from selected and most prolific varieties, has never failed to run. Per Brick, enough for 8 square feet, $35 \mathrm{c} ; 5$ for $\$ 1.50$, by mall, postpaid. By express, at buyer's expense, per Brick, 25c; 6 Bricks, $\$ 1.40$; 12 Bricks, \$2.75.

MUSHROOMS. How to Grow Them. The most practical work on the subject ever written. Describes how they may be grown with prot by market gardeners and also how to grow them for home use. 170 by market
pages. $\$ 1.00$. 
1 ounce to 30 hills;

4 lbs. per acre.

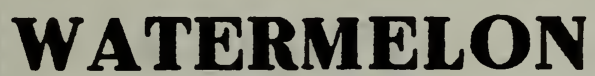

WASSERMELON
Ready from 90 to

140 days from seed.

To get good strong vines early in the season, form large, well drained hills of earth, made rery rich, about eight feet apart. In these plant the seed as soon as the ground is warm and dry, and carefully protect the young plants from insects, and hasten their growth by the use of liquid manure. ls., light seed; ds., dark seed.

ALABAMA SWEET. 1s.. A large and attractive Melon, oblong in shape, early in maturing, and very sweet. 'Pkt., 5c; oz., 10c; $1 / 4$ 1b., 25c; 1b., 75c.

BLACK BOULDER. ds. It is enormously productive, nearly round in shape, reaching a mammoth size, with rich dark green skin; flavor equal to any melon, and shipping qualities excellent. Pkt., 5c; oz., 10c; 1/4 1b., 20c; 1b., 65c; postpaid.

COLE'S EARLY. ds. This is a very choice melon for the home garden and can be grown farther north than any other variety. The flesh is bright red, crisp, and very delicate in texture, sweet and refreshing in flavor. It is an abundant bearer, of medium size, but very solid, with thin rind. Pkt., 5c; oz., 10c; 1/4 1b., 20c; lb., 55c.

CUBAN QUEEN. ds. One of the largest varieties, skin striped dark and light green; heavy cropper; flesh bright red, luscious, crisp, sugary. A favorite melon for home and market. One of the best keepers, and a first rate shipper. Pkt., 5c; oz., 10c; 1/4 lb., 20c; 1b., 55c; postpaid.

DUKE JONES. (Jumbo.) ls. Very large, nearly round, dark green; flesh solid, deep red, and of Ine quality. Very productive. A good shipper. Pkt., 5c; oz., 10c; $1 / 4$ lb., 20c; 1b., 60c; postpaid.

HALBERT'S HONEY. Is. A splendid sort for home use or local market. Vine vigorous and productive; fruit large and oblong; color dark glossy green; flesh very bright, rich red, and exceedingly sweet, extending close to the rind, too crisp and brittle to be a good shipper. Pkt., $5 c$; oz., 10c; 1/4 1b., 25c; 1b., 75c; postpaid.

ICE CREAM. (Peerless.) is. It is medium in size, almost, round; the skin is a pale green, slightly mottled; flesh bright scarlet, solid to the center, sweet, melting and delicious. Pkt., 5c; oz., $10 \mathrm{c} ; 1 / 4$ lb., 20c; lb., 55c; postpaid.

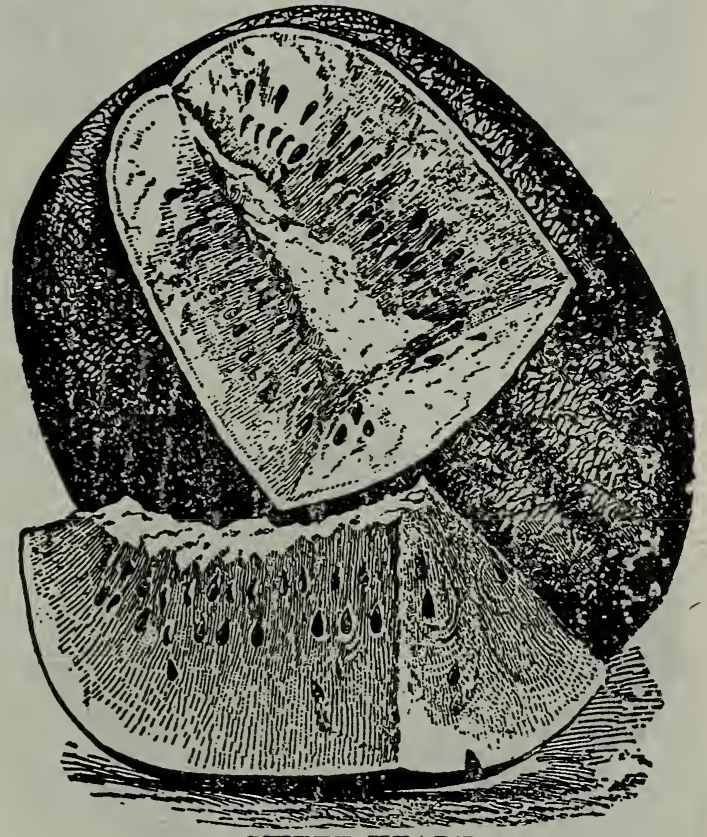

SWEET HEART

SWEET HEART. ds. Vine vigorous and productive, ripening its fruit early; fruit large, oval, very heavy, uniformly mottled, light and light green; rind thin but firm; flesh bright red, flrm and solld, but very melting and sweet. The melons retain their good quality for a long time. Pkt., 5c; oz., 10c; $1 / 4$ 1b., 20c; 1b., 55c; postpaid.

MCIVER'S WONDERT U L SUGAR. Is. The melons attain a great weight, are of a very handsome appearance, never crack or lose their fine flavor. It is a very productive and hardy variety and one that will take the lead wherever known; oblong; striped skin. Pkt., 5c; oz., $10 c$; $1 / 4$ lb., 20c; 1b., 65c; postpaid.

KLECRLEY SWEETS. (Monte Cristo.) 1s. Large oblons melon, skin dark green. The KLECKLEY SWEETS

rind is only about one-half inch in thickness. The scarlet flesh is sweet and sugary and is of such texture that it leaves no
strings of pulp in eating. The melon is better for home use than for shipping, and we believe it strings of pulp in eating. The melon is better for home use than for shipping, and we believe
ts the best table melon today. Pkt., 5c; 0z., 10c; 1/4 1b., 25c; 1b., 75c; postpaid. Oz. 1/4 1b. 1b.

Large pkt., 5c. Deduct 10 cents per pound if by express. All Postpaid colorado PRESERviNg CITRON. (Green seed.) For Preserves.............................. \$0.10 \$0.20 $\$ 0.60$ DIXIE. ds. Fruit oval, large, early, and of flne appearance. Skin dark green, striped, flesh deep scarlet, sweet, tender and juicy.

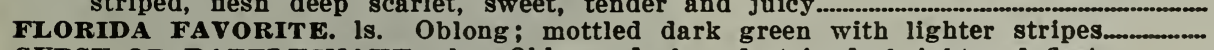
GYPSY OR RATTLESNAKE. ls. Oblong, dark and striped; bright red flesh................. GRAY MONARCH (White Icing). ls. Large, long; crimson flesh, light skin...................... KENTUCKY WONDER. Is. Large, oblong, dark green, red seed and flesh KLOB GEM. ds. Striped, very large and an excellent shipper.

MOUNTAIN SWEET. ds. Early, fruit large, oval, rind dark green, flesh scarlet, solid dark green skin.

PHINNEY'S EARL $Y$. Is. Extra early, oblong; flesh pink.

$\begin{array}{lll}.10 & .20 & .55 \\ .10 & .20 & .60 \\ .10 & .20 & .55 \\ .10 & .20 & .55 \\ .10 & .20 & .56 \\ .10 & .20 & .50\end{array}$


ONE OUNCE TO 300 FT.

OF DRILL; 4 TO 5 LBS.

TO THE ACRE.
ONIONS

ZWEIBELN
Ready for green onions in 60 days. Main crop matures in 130 to 190 days from sowing.

The onion is most successfully grown in a rich, sandy loam. Continued cultivation upon the same plot of ground, contrary to the general rule, rather improves the crop than otherwise. As early as the ground can be worked in the spring, sow the seeds in drills 14 inches apart, covering half an inch. When the plants can just be seen in the rows, commence hoeing, just skimming the surface. Subsequently weed thoroughly and carefully by hand. When the tops die, pull the onions and spread evenly over the ground; stir or turn until thoroughly dried, then cut the tops off one-half inch from the bulb.

\section{NOTICE}

Take off 10c per lb. if seed goes by freight. Take off $10 \mathrm{c}$ per $1 \mathrm{~b}$. in 5 lb. lots.

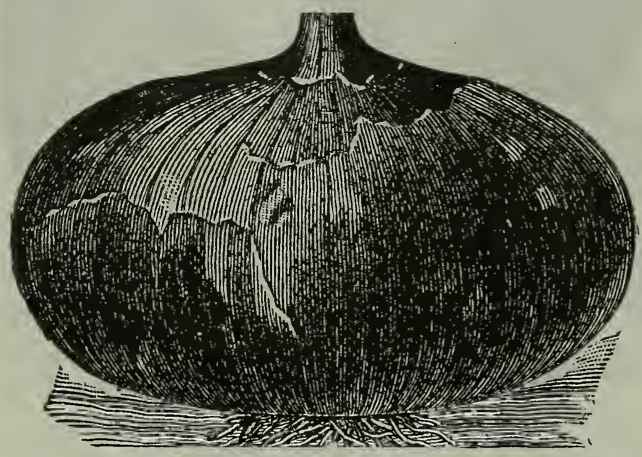

RED WEATHERFIELD
PRIZE TAKER. It is of immense size, nearly a perfect globe, with thin skin of bright straw color. It ripens up hard and fine, and presents a handsome appearance. The flesh is pure white, fine grained, mild ard delicate in flavor. Pkt., כс ; oz., 15c; 1/4 lb., 45c; lb., \$1.35; postpaid.

WHITE PORTUGaL. (Silver Skin.) A large flat onion of mild flavor and great beauty; an excellent early ripening sort. Pkt., 5c; oz., 20c; $1 / 4$ lb., 65 c; lb., $\$ 2.10$; postpaid.

WHITE QUEEN. For pickling; small, flat, pure white; excellent flavor. Pkt., 5c; oz., 15c; 1/4 1b., $45 \mathrm{c} ; 1 \mathrm{~b} ., \$ 1.35$; postpaid.

SOUTHPORT WHITE GLOBE. Very large, solid and handsome; deep globe. Pkt., 5c; oz., 20c; $1 / 4$ lb., 65c; lb., $\$ 2.10$; postpaid.

SOUTHPORT YELLOW GLOBE. Very large, deep globe; skin rich golden yellow; fine keeper. Pkt., כc; oz., 15c; 1/4 lb., 40c; lb., $\$ 1.10$; postpaid.

SOUTHPORT RED GLOBE. Large, matures late; a splendid keeper; of fine quality. Pkt., כ̌; oz., 15c; $1 / 4$ lb., 45c; lb., $\$ 1.25$; postpaid.

YELLOW GLOBE DANVERS. A fine productive variety, of medium size, skin coppery yellow, flesh white, comparatively mild and well flavored. Best of keepers. Pkt., 5c; oz., 15̌c; $1 / 4$ lb., 40c; 1b., $\$ 1.25$; postpaid.

AUSTRALIAN BROWN. Distinct from all others; is nearly round, wonderfully hard and solid, ripens extremely early; never makes scullions; of medium size, skin a deep amber brown, flesh mild anil agreeable. No other onion has such keeping qualities. Pkt., 5c; oz., 15c; 1/4 lb., 40c; lb., \$1.40; postp'd.

EXTRA EARLY RED FLAT. Matures very early, yields abundantly, and is of mild flavor; medium size; deep red and solid. Poor keeper. Pkt., 5̋; oz., 15c; $1 / 4$ lb., 45c; lb., $\$ 1.35$; postpaid.

GLOBE WETHERSFIELD RED. Remarkable for size, earliness, productiveness, beauty of color, perfection of shape, and long keeping qualities. Possesses all the excellent qualities of Red Wethersfield and Yellow Globe Danvers. Pkt., כ̌c; oz., 15c; $1 / 4$ lb., $45 c$; lb., $\$ 1.25$; postpaid.

LARGE RED WETHERSFIELD. This is the standard and favorite variety. Large size, deep, purplish white, stronger flavored than lighter varieties. Very productire and an excellent keeper. Pkt., 5̌; oz. $15 c ; 1 / 4$ lb., 40c; lb., $\$ 1.10$; postpaid.

MAMMOTH SILVER KING. Handsome flat onion of enormous size, silvery white, tender, of a mild sweet flavor. The best keeper among the white varieties. Pkt., 5c; oz., 20c; 1/4 1b., 55c; lb., $\$ 1.60 ;$ postpaid.

\section{ONION SETS}

\begin{tabular}{|c|c|c|c|}
\hline & \multicolumn{3}{|c|}{ Postpaid By Express } \\
\hline A & pt. & qt. & \\
\hline 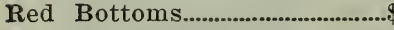 & $\$ 0.15$ & $\$ 0.25$ & $\$ 0.15$ \\
\hline 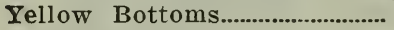 & 15 & .25 & .1 \\
\hline White Bottoms.................................. & .20 & .30 & "? \\
\hline 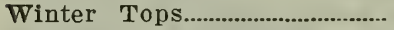 & 10 & .20 & 1.1 \\
\hline
\end{tabular}

Write us for prices on onion sets in large lots.

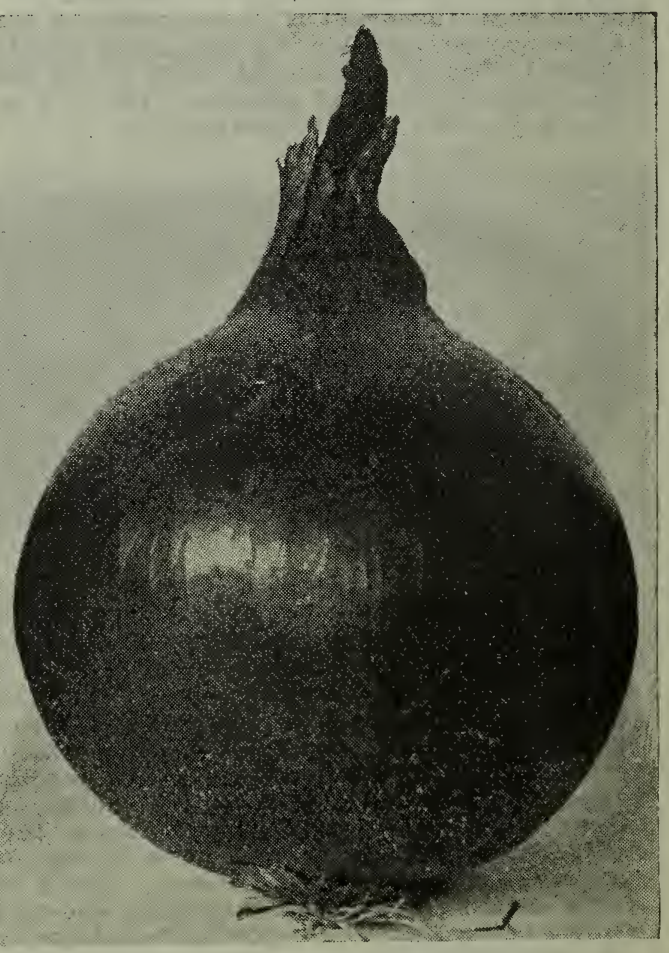

RED GLOBE WEATHERFIELD 


GROWN IN THE FAR
NORTH

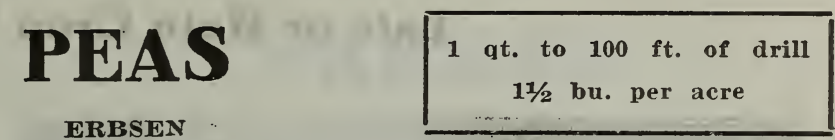

For first early. Peas sow in a light, rich soil, as early in March or April as the ground can be worked; for later varieties, sow in April or May. Discontinue sowing from June to August, after which, by sowing an extra early sort, a good crop can generally be secured. As Peas suffer considerably from drought during the hot summer months, it will be found of great benefit to sow. the Peas in a trench six inches in depth, covering the Peas to a depth of two inches. As soon as sufficient growth has been made draw the earth about the vines. In this way a great deal more moisture is kept about the roots than if sown on the level and afterwards hilled up. The wrinkled varieties are not so hardy as the smooth sorts and should be planted later, owing to their liability to rot in the ground, but are much superior in flavor to the smooth Peas. Dwarf varieties sow in rows one foot apart, and taller sorts from 2 to 3 feet apart. Those marked thus * are wrinkled and sweet.

\section{NOTICE}

If sent by express at buyer's expense, 8c per nint or $15 \mathrm{c}$ per quart may be deducter from above prices.

\section{Extra Early Varieties}

ALASKA. $2 \mathrm{ft}$. The earliest blue pea, of good flavor, dark green pods, well filled and ripen uniformly. One of the very best for market gardeners. Pkt., acc; pt., 25c ;. qt., 40c; postpaid.

*AMERICAN WONDER. $1 \mathrm{ft}$. Of the finest quality. Very prolific, with pods of fine size and form; requires no brush or support. It may be planted a week apart for succession. Pkt., 5c; pt., 25̆c; qt., 45c; postpaid.

*MCLEAN'S LITTLE GEM. $1 \mathrm{ft}$. An early dwarf, green, wrinkled pea, of superior flavor and very prolific. Pkt., 5c; pt., 25c; qt., 45c; postpaid.

*NOTT'S EXCELSIOR. $1 \mathrm{ft}$. Earliest wrinkled pea; of close, compact, dwarf growth. The pods average 3 inches in length, and are well filled to the squared ends with large peas, un. usually sweet. It not only yields heavily in pods, but also in shell peas. Pkt., 5c; pt., $25 \mathrm{c}$; qt., $45 \mathrm{c}$; postpaid.

*PREMIUM GEM. $11 / 2 \mathrm{ft}$. The pods are large and crowded with six to eight very large peas of fine quality. The seed is green, large, wrinkled, often flattened. Pkt., 5c; pt., 25c; qt., 4 ăc; postpaid.

FIRST AND BEST. $2 \frac{1}{2} \mathrm{ft}$. Very early, productive, pods good size and well filled. A favorite market pea. Pkt., 5c; pt., 25c; qt., 40c; postpaid.

*GRADUS, OR PROSPERITY. 21/2 ft. An extra early wrinkled variety bearing immense pods, large peas of finest quality, superior both in size and delicious flavor. Pkt., 5c; pt., 30c; qt., $50 \mathrm{c}$; postpaid.

TOM THUMB. 9 in. A smooth, white sort, very dwarf. Pkt., כ̌c; pt., 25c; qt., 45c; postpaid.

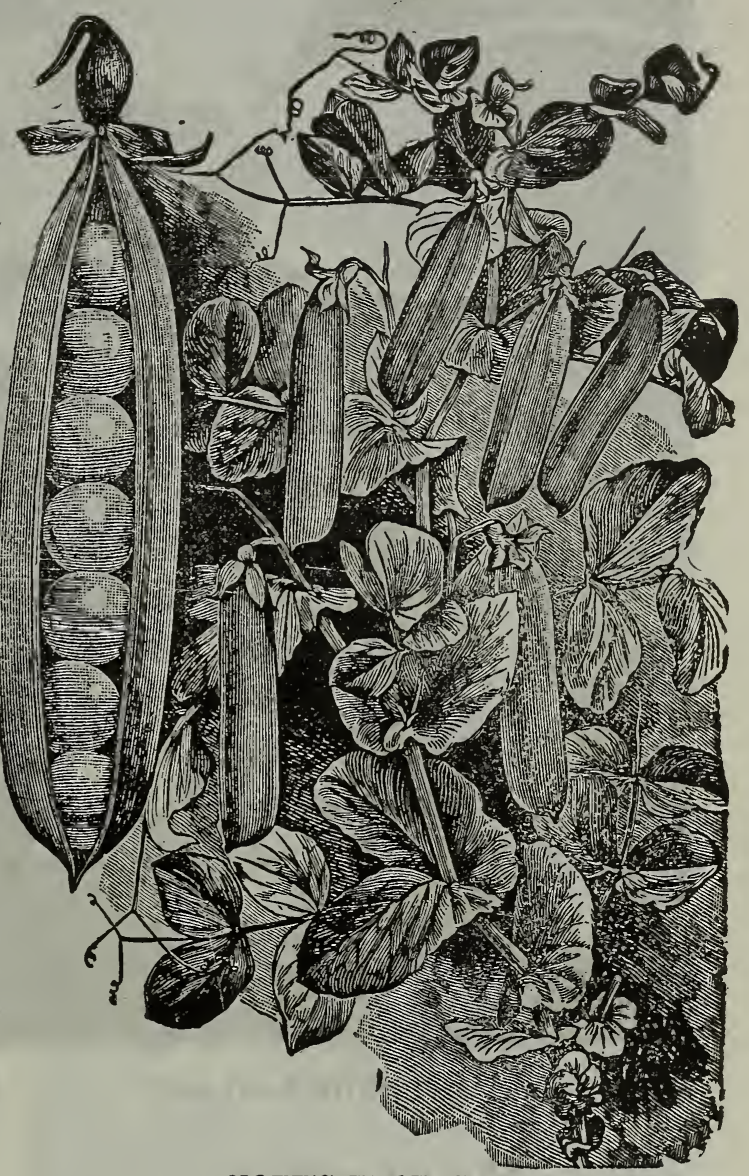

NOTT'S EXCELSIOR

\section{Second Early or Medium Variety}

*ABUNDANCE. $2 \mathrm{ft}$. Long, round, well filled pod, productive, quality perfect. Pkt., 5c; pt., 25 c; qt., $45 c$; postpaid.

*ADVENCER. $2 \frac{1}{2} \mathrm{ft}$. Long pods which are abundantly produced, and well filled to the end; of excellent flavor. A first-class pea in every respect. Pkt., 5c; pt., $25 c$; qt., $45 c$; post. paid.

*EVERBEARING. $2 \mathrm{ft}$. Peas are rery large, of excellent quality. For continuance and profusion of bearing, this variety is unexcelled, which gives especial value for the late summer and autumn use. Pkt., 5c; pt., 25c; qt., 45c; postpaid.

*HORSFORD'S MARKET GARDEN. $2 \mathrm{ft}$ A great favorite with the market gardeners. Pods are large, well filled with large peas of a delicious sweet flavor. A prolific bearer. Pkt., כc; pt., 25̄c; qt., 45̄c; postpaid.

I am puskegon Co., Mich., Oct. 30, 1912 $I$ am positive that Sand Vetch is the only chance. for the farmers in these parts, both as a
turn-under and as feed for cattle. FRANK S. SCIOLL. 


\section{Late or Main Crop Varieties}

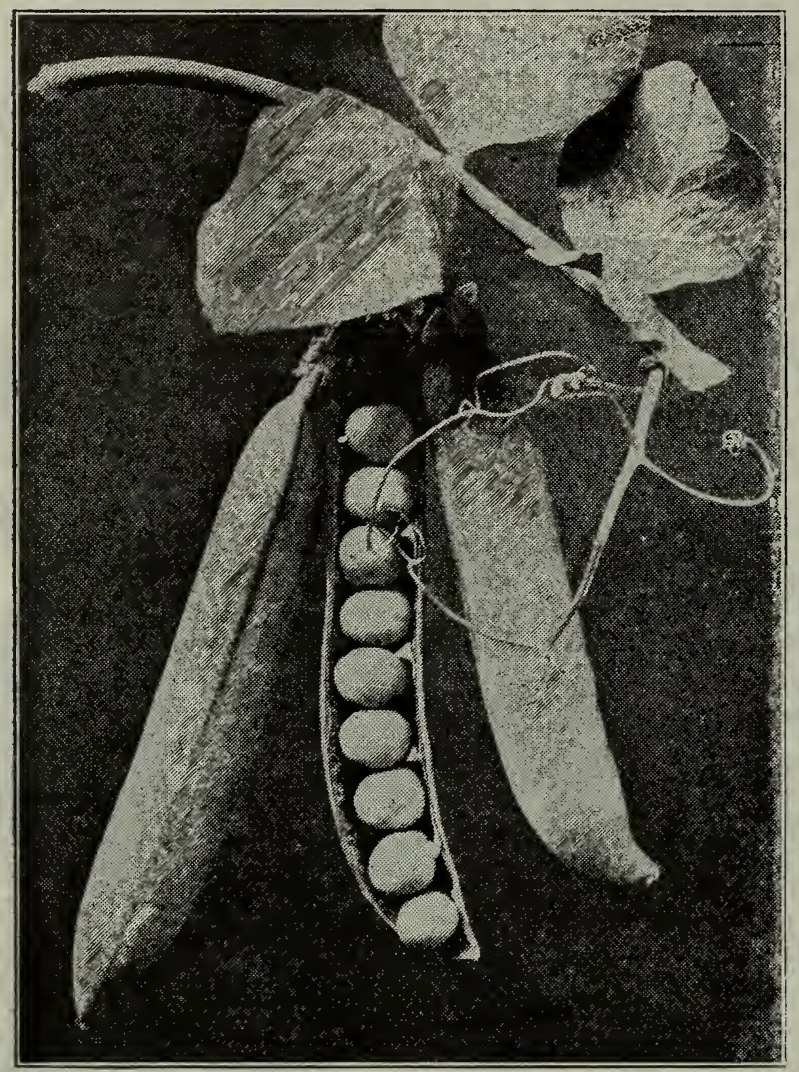

For a succession of tall growing verietles plant Gradus, Advancer, Champlon of England.

-CHAMPION OF ENGLAND. 4/2 ft. Vines are heavy, pods large, nearly stralght, and well filled with tender peas, which are sweet and of excellent quality. It is a profuse bearer, most reliable late sort. Pkt., sc; pt., 25c; qt., 45c; postpaid.

*TELEPHONE. $4 \mathrm{ft}$ Immenwely productive. The pods are very large, so well filled with peas of excellent qual. ity that Telephone has become one of the most prominent late leas to be grown for market. Pkt., 5.; pt., 25c; qt., 45e; postpaid.

- mProved stratagem. $2 \mathrm{ft}$. Vines of strong growth with large follage; do not need any support. Pods of large size, well nlled with large, dark green peas of rich, sweet flavor. One of the very finest. Pkt., 5c; pt., 25c; qt., 45c; postpaid.

WHITE MARROWFAT. $4 \mathrm{ft}$. Vines are very robust. Bears many pods; alway. well flled. The peas are of only ordinary quality. Pkt., 5c; pt., 20c; qt., 35c; postpaid.

MELTING SUGAR. This is the best of the edible podded peas. The pods grow about 5 to 6 inches long, are stringlese and very tender, and may be used the same as a snap bean; 3 to $4 \mathrm{ft}$. Prt. 5c; pt., 30c; qt., 45c; postpaid.

CANADA FIELd AND COW PISAs. (See Forage Plants, page 7.)

*Wrinkled and Sweet.

CHAMPION OF ENGLAND

\section{Parsnips}

\section{PASTINAKE}

1 oz. to 100 feet of drill, 5 or 6 lbs. per acre. Matures in 125 to $\mathbf{1 4 0}$ days from seed.

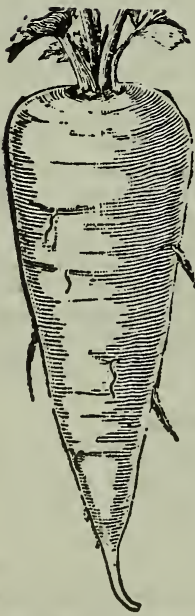

Sow in April or early May. Cultivate the same as carrots. They may be dug in the autumn and stored for winter use, but if left in the ground till spring are very much improved in flavor. Sow a liberal quantity of seed, as from its nature it does not always come up well.

\section{HOLLOW CROWN. Standard} variety; roots long, very smooth; white, tender, sugary, and of excellent fiavor. Pkt., 5c; oz., 10c; $1 / 4$ lb., 20c; lb., 55c; postpaid.

IMPROVED GUERNSEY. (Improved Half Long.) The roots do not grow so long as the Hollow Crown, but are of greater diameter and more eas. Ily gathered. Very smooth, the flesh fine grained and of excellent quality. Pkt., 5c; oz., 10c; $1 / 4$ lb., 20c; 1b., 55c; postletid

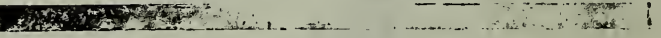

\section{Okra or Gumbo}

\section{ESSBARER SAFRAN}

$1 \mathrm{oz}$. to 40 feet of drill. Ready for table in from 90 to 105 days from seed.

The pods when young are used in soups, stews, etc. The plants are of the easiest culture. Sow at the usual time for all tender vegetables, in drills two inches deep, setting the plants 2 feet apart.

IMPROVED DWARF. An early variety, pod comparatively short but very numerous. Pkt. 5c; oz., 15c; $1 / 4$ 1b., 25c; postpaid.

WHITE VELVET. Pods round, smooth, large and attractive; produced in great abundance. Pkt., 5c; oz., 15c; 1/4 1b., 25c; postpaid.

\section{Peanuts}

Culture very simple. Plant in light, sandy soil in April, in pod or shelled, two to a hill on level ground. Hill up from time to time as required. IPkt., 5c; 1b., 25c; postpaid.

Woods Co., Okla., Mar. 18, '11. I wish to say that we are well pleased with your seeds, as they do well in this locality. and we recommend them to our neighbors. VIRGIL A. WALKER. 


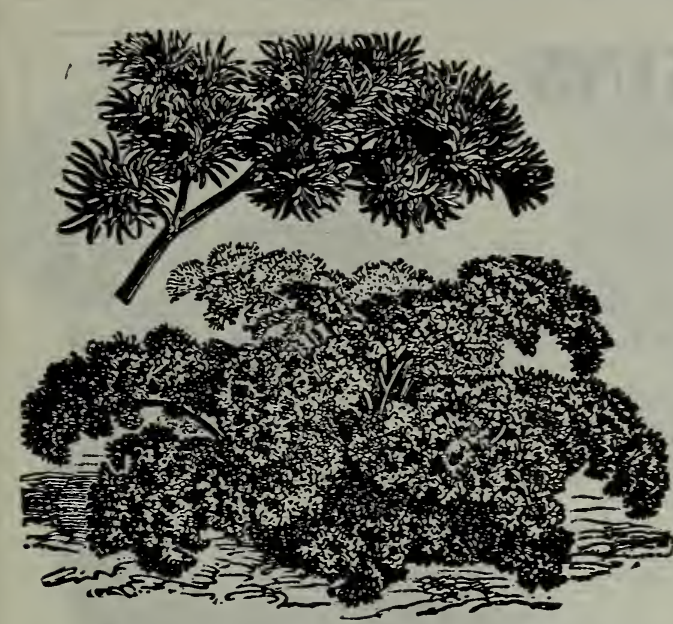

\section{PARSLEY}

\section{PETERSILIE}

102 . to 150 feet of drill.

NOTICE
On account of the dry weather Beets, Carrots,
Peas and Parsley are almost entire fallures.
This accounts for high price.

Soak the seeds a few hours in lukewarm water and sow early in the spring in drills one foot apart. Thin out to four inches. A few seeds sown in onion rows use no space. To preserve in winter, transplant to a light cellar or glass frames. Used for garnish. Ing and seasoning.

CHAMPION MOSS CURLED. The plant resemble a tuft of finely curled moss, leaves extra large, and a rich deep green. Valuable for garnishing and also as ornamental foliage plants for borders of beds. Grows in window boxes. Pkt., 5c oz., 15c; $1 / 4$ lb., 35c; lb., $\$ 1.00$; postpaid.

CHAMPION MOSS CURLED PARSLEY

EXQUISITE. Beautiful and closely curled leaves of dark green, flavor excellent. As a pot plant for winter in window or on dining table it is simply "exquisite." Pkt., 5c; oz., 15c; 1/4 1b., 35c; lb., \$1.00; postpaid.

TURNIP-ROOTED OR HAMBURG. The root is the edible part. Used for flavoring soups. Pkt., Bc; oz., 15c; $1 / 4$ lb., 35c; lb., $\$ 1.00$; postpaid.

Requires from 135 to 160
days from sowing to ma-
turity.

The small peppers are the hottest, the large varieties being quite mild in fiavor. Sow in hotbed early in April and transplant to the open ground when weather is favorable. They may also be sown in the open ground when danger of frost is past and the soll is warm.

CHINESE GIANT. An extremely large sweet pepper, deep scarlet when mature, simllar in hape to Large Bell, but more than twice as large. Strong, vigorous and productire. Prt., 5c; oz.. $30 \mathrm{c} ; 1 / 4$ lb., $90 \mathrm{c}$; postpald.

GOLDEN DAWN. Golden yellow; mild and sweet, size and shape of Large Bell. Pkt., 5c; oz., 25c; $1 / 4 \mathrm{lb} ., 65 c$; postpaid.

LARGE BELL. OR BULL NOSE. Large and early; square shouldered, flesh thick, hard, and less pungent than most other sorts; much used for mangoes. Pkt., 5c; oz., 25c; $1 / 4 \mathrm{lb}$., 65c; postpaid.

LONG RED CA YENNE. Bright red; pods slender, hot and pungent. Pkt., 5c; ob., 25c; $1 / 4$ 1b., 65c; post paid.

MONSTROUS. Of an irregular conical shape, one sire usually being convex, the other concave. One of the most mild in flavor. Very large and of leep red color wben ripe. Pkt., 5c; oz., 30c; $1 / 4$ lb., 75c; postpaid.

RED CHILI. Very productive, small, red, very hot. Excellent for pepper sauce Pkt., 5c; oz., 25c; postpaid.

2UBY KING. Fruit very large, scarlet, sweet, of mild fiavor, flesh quite thick, one of the best. Pkt., 5c; oz., 25c; 1/4 1b., 65c; postpaid.

BWEET MOUNTAIN. Nearly, if not quite, Identical with Bull Nose. Pkt., 5c; oz., 25c; $1 / 4$ lb., 65c; postpaid.

Deuel Co., Nebr., July 28, 1912. I have a fine stand of onlons. The seed was all 0 . K. I am well pleased with the Iron Age Drill and Cultivator and can cheerfully recommend it to anyone. GEO. W. EAGELSTON.

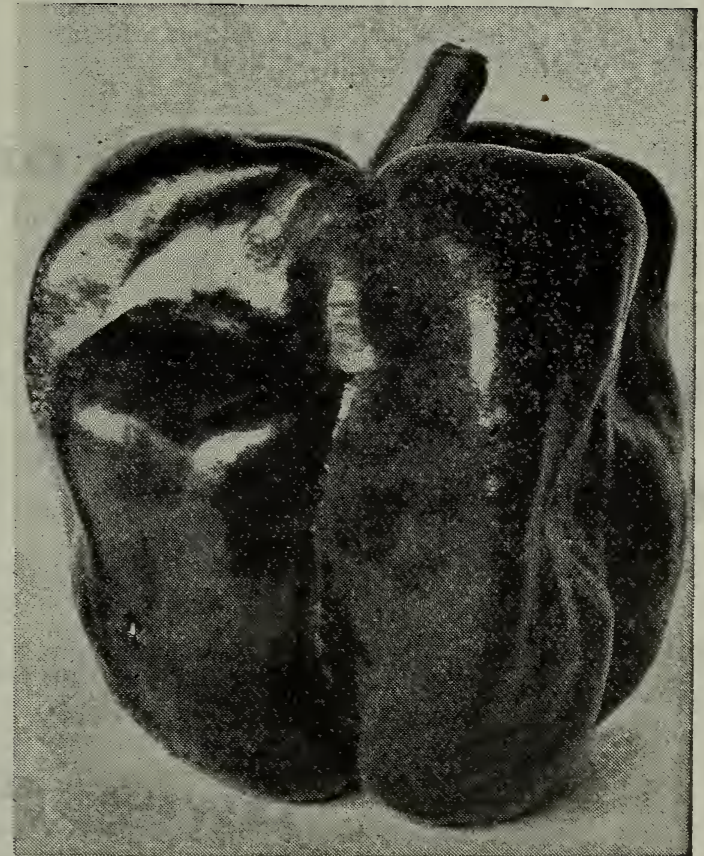

CHINESE GIANT

PEPPER PLANTS, Page 14.

Kearney Co., Mar. 16, 1911. We are sending you a large order for seeds and sets and hope you will do well by us. We have ordered seeds of your frm before and they have been very satislactory. W. H. WHITEHEAD. 
One ounce to 50 hills;

3 to 4 pounds per acre.

\section{PUMPKINS KOERBIS}

From 100 to 120 days from sowing seed to maturity.

Pumplins are planted frequently in connection with a crop of corn, or as a second crop after early peas, etc. The following are all thin and tender skinned varieties, as distinctive from the hard or thick-shelled squashes. The fruits are quite susceptible to frost and should be gathered and stored in a cool, dry place. If bruised they will not keep any length of time.

SMALL SUGAR. Fruits of small size, averaging about ten inches in diameter, of excellent keeping qualities, flattened, slightly ribbed. Skin deep orange-yellow, flesh sweet. Ver. early. Pkt., 5c; oz., 10c; $1 / 4$ lb., 20c; lb., 60c; postpaid.

LARGE SWEET CHEESE. Fruit flattened; skin rich cream color; flesh yellow, thick, tender, iarge, hardy and productvie. Excellent for table use. Good keeper. 'Pkt., 5c; oz., 1nc; 1' lb., 20c; lb., 60c; postpaid.

CONNECTICUT FIELD. Very productive, largely grown for feeding stock. Pkt., 5c oz., 10c; $1 / 4$ lb., 15c; lb., 40c; postpaid.

SWEET POTATO. Pear shaped, gooci size, skin creamy white. The seed is all in the cavity of the large end, the thick neck being solid; exceptionally fine quality. Pkt., 5c; oz., 10c; $1 / 4$ lb., 25c; 1b., 75c; postpaid.

JAPANESE PIE. Early and productive, of medium size, large at one end, terminating in a crooked neck. Skin deep green with darker stripes; flesh is a rich salmon color, excellent quality; a good keeper. Pkt., 5c; oz., 10c; 1/4 lb., 25c; lb., 75c; postpaid.

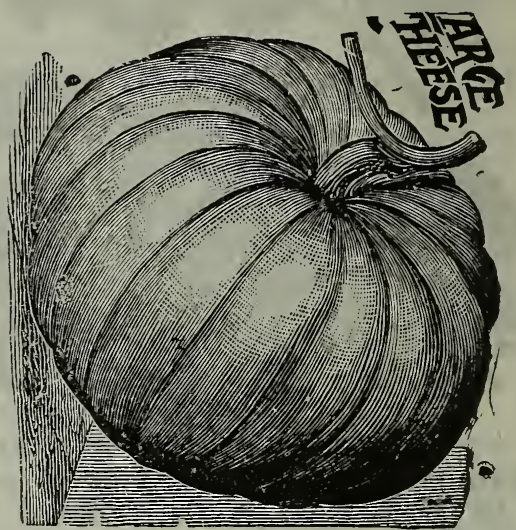

CUSHAW, OR CROOKNECK. (Sometimes called a squash.) Productive; color light cream, sometimes lightly striped; flesh salmon colored, mealy and sweet. Pkt., 5c; oz., 10c; $1 / 4$ lb., 25c; 1b., 70c; postpaid.

KING OF THE MAMMOTHS. (Jumbo or Pot iron.) Weighs from 40 to 150 pounds. Round flattened at both ends, skin and flesh bright yellow. It makes a good table pumpkin. Good keeper. Pkt., 5c; oz., 10c; 1/4 1b., 30c; lb., 90c; postpaid.

\section{Rhubarb or Pie Plant}

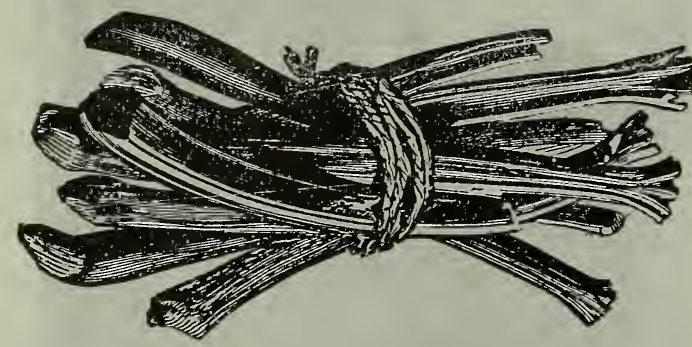

RHUBARB ROOTs. Set in spring and they wir be ready for use the following season. 10c each, postpaid; $5 \mathrm{c}$ each, 50c per doz., by ex., not prepaid.
The richer the ground is the better. Sow in drills an inch deep, and thin out to six inches apart. In the fall transplant into rery highly manured and deeply stirred soil, setting them four feet apart, and give a dressing of coarse manure every spring. The stalks should not be plucked until the second year, and the plant never allowed to exhaust itself by running to seed. In removing be careful to pull off close to the roots 'nstead of cutting.

VICTORIA. Stalks very tall and large; skin thick and red-stained; pulp quite acid; very productire. Pkt., 5c; oz., 15c; 1/4 lb., 40c; postpaid.

LINNAEUS. A large and tender sort, sometimes called wine plant. Pkt., 5c; oz., 15c; $1 / 4$ lb., 40c; postpaid.

\section{Sweet Potatoes}

One bushel of Potatoes should produce 2,000 sprouts. 6,000 to 7,000 plants to the acre.

Succeed best in light, sandy loil. Stablemanure is the best fertilizer. To obtain the sprouts. the entire potatoes are planted in beds, say 5 or 6 feet wide, and as long as required, the bed being opened 20 inches deep, filled with stable manure, and covered with 4 inches of sand. The potatoes are placed upon the sand 1 inch apart and corered with an inch of sand. This is corered with old hay or trash till the sprouts appear, when more sand is added, after removing trash, till it is 4 inches in depth on top of the potatoes. The sprouts must be detached from the tubers without disturbing them. To do this hold the tuber in place with the left hand while the sprout is taken with the right. The sprouts are transplanted to the field and placed in rows 4 feet apart by a foot in the row. Ninety days are generally allowed from transplanting to digging.

YELLOW JERSEX, YELLOW NANSFIOND These are the most desirable varieties. Ready about April 1. Write for prices.

SWEET POTATo PLANTS. Ready about May 1. For prices see page 14. 


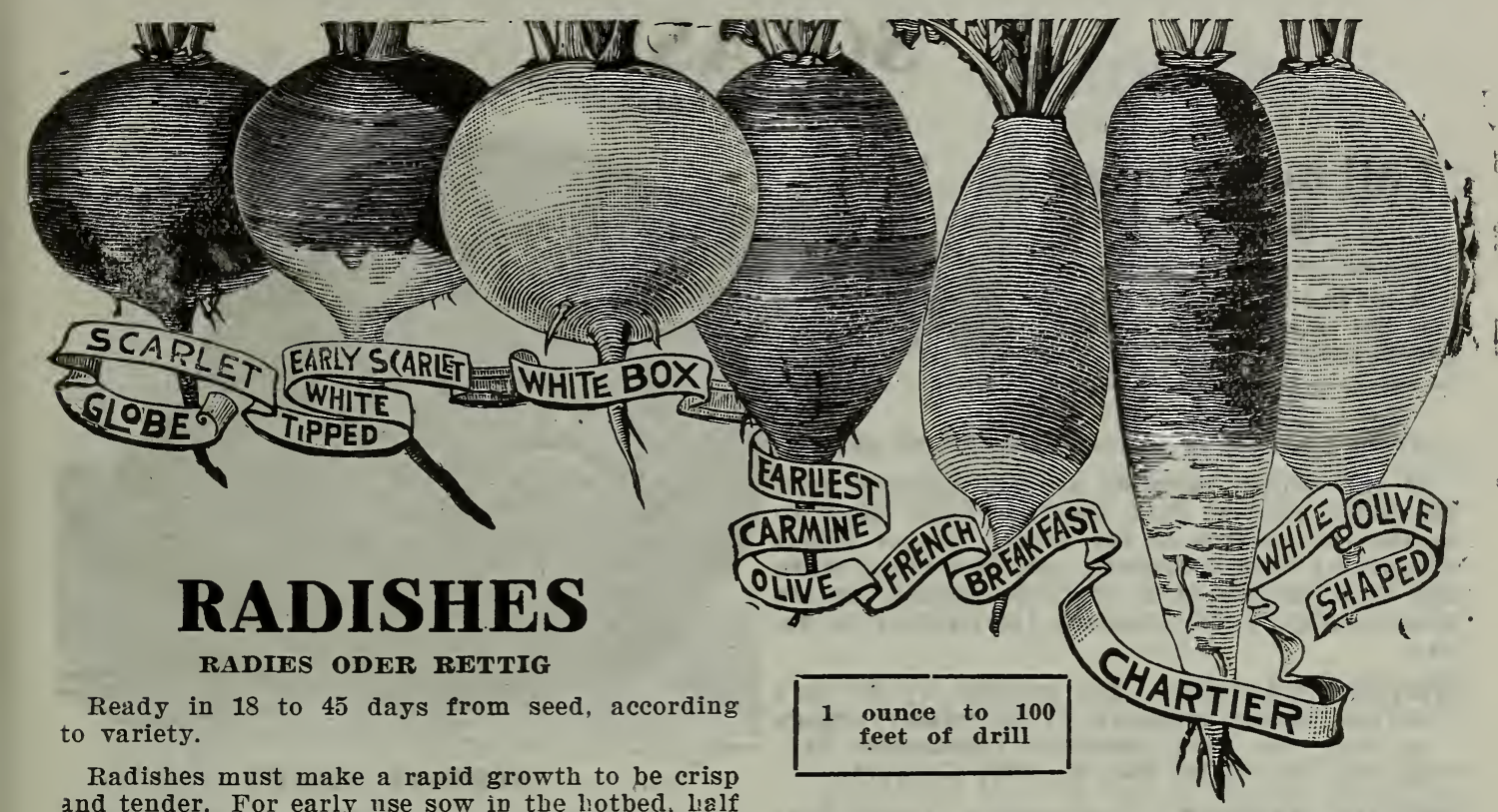
and tender. For early use sow in the lotbed, lialf an inch deep. For an early crop in the open ground sow thinly in drills on rich, sandy soil as early in the spring as it is fit to work. For a succession sow every two weeks.

- EARL Y BIRD. Bright red turnip, medium size. Ready to pull in 20 days after sowing. Pkt., 5c; oz., 10c; $1 / 4$ 1b., 20c; lb., 60c; postpaid.

- GIANT CRIMSON GLOBE. This is a new variety suitable for forcing or early planting out of doors. It will grow to 6 and 7 inches in circumference and still remain solid and juicy, often 4 inches across. It is round to oval, and is very attractive. Pkt., 5c 0z., 10c; $1 / 4 \mathrm{lb} ., 25 \mathrm{c}$; lb., 70c; postpaid.

GLASS OR CINCINNATI MARKET. This new radish is a fine acquisition. It is a long radish of light red color, of uniform size. The flesh is transparent white, always crisp and brittle, even if grown to a large size, and mild flavored. Pkt., 5c; oz., 10c; 1/4 lb., 20c; lb., 60c; postpaid.

\section{OTHER POPULAR EARLY AND SUMMER RADISHES}

Large Packets, 5c. Deduct 10c per pound if by express. TURNIP SHAPED VARIETIES

By Mail Postpaid

* NON PLUS ULTRA. The standard forcing Radish; roots dark red, crisp and tender..\$0.10 $\$ 0.20 \quad \$ 0.60$ EARLY SCARLET TURNIP. Very early for general use....................................................... $.10 \quad .20 \quad .55$

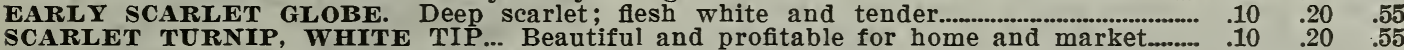

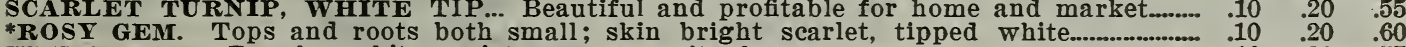
WHITE BOX. Popular white variety, grows quite large...................................................................... $\quad .10 \quad .20$

\section{OLIVE-SHAPED SORTS}

*EARLIEST CARMINE OLIVE. Excellent quality, very bright and attractive............. $\quad .10 \quad .20 \quad .60$ *WHITE OLIVE FORCING. White flesh and skin; crisp and mild flavor........................... $.10 \quad .20 \quad .60$

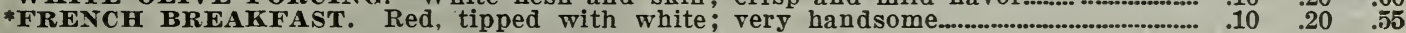

\section{LONG VARIETIES}

LONG SCARLET, SHORT TOP. The standard long scarlet variety.

WHITE VI OR SHEPHERD. Large, long, summer radish; scarlet, white tip....

WHITE STRASBURG. Most popular summer sort, 4 inches long, 2 inches thick. SUMMER RADISHES, MIED. Round and long.

\section{WINTER SORTS}

Sow in July. Pull before severe frost and store in damp cellar.

CHINESE ROSE. (Scarlet China.) Large oval, bright rose-colored, good keeper

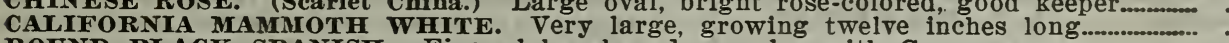
ROUND BLACK SPANISH. Fine globe shaped, popular. with Germans.

LONG BLACK SPANISH. Black skin; white flesh, long, will keep until
*For greenhouse forcing, hotbed planting or for extra early outdoors.

$\begin{array}{lll}.10 & .20 & .55 \\ .10 & .20 & .55 \\ .10 & .20 & .65 \\ .10 & .20 & .65 \\ .10 & .20 & .55\end{array}$




\section{SQUASH \\ SPEISE KUEREISZ}

\section{Fall and Winter Sorts}

1 ox. to 20 hills; 8 to 4 lbs. to the acre. Hill 8 feet apart each way.

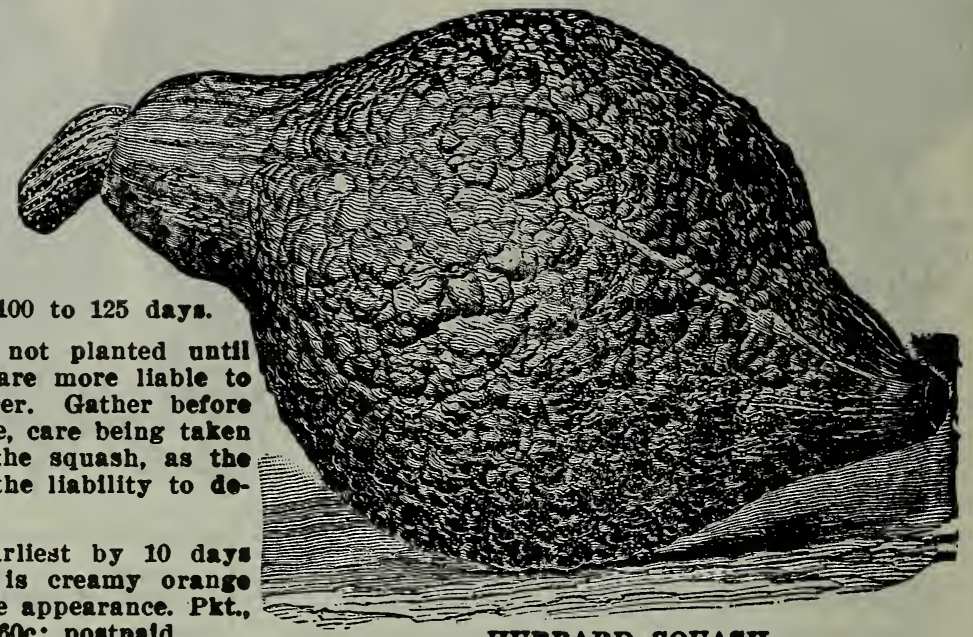

From planting to maturity 100 to 125 day.

If the winter varieties are not planted until the latter part of June they are more liable to escape the ravages of the borer. Gather before injured by frost for winter use, care being taken not to break the stem from the squash, as the lightest injury will increase the liability to docay.

ORANGE MARROW. The earliest by 10 day of the winter squashes. It is creamy orange bc: oz., 10c: $1 / 4$ lb., 25c: lb., 60c: postpald.

BOSTON MARROW. (Autumnal.) Large, otal form, skin bright orange, mottled with cream color: flesh rich salmon yellow, fine grained and good flavor, unercelled for ples. Pkt., 5c; or., 10c: $1 / 4$ lb., 25c; lb., 60c: postpaid.

ChICAgo WARTED hUBbard. Large nite, dark green color, distinguished by a dence covering of knots (warts), a sure indication of splendid quality, thick flesh; good keeper. Plat., 5c; oz., 10c: $1 / 4$ lb., 25c: lb., 75c; postpaid.

GOLDFN HUBBARD. Similar to the above except that the skin is deep orange jellow. Flemh nne grained and of excellent flaror. Plit., be; ox., 10e; $1 / 4$ lb., 30e; lb., 80c ; postpaid.

MAMMO'H CHWI. Enormous wize, round, tattened at ends, ukin orange color and slightly ribbed. Flesh thick and deep yellow. Pkt., bc; oz., 10e; $1 / 4$ lb., soc; lb., 90e: postpaid.

PIRFECT GKM. Nearly round: kin cresmy white flegh fine gralued. Vine bears great number of manll squashes. Plt., 5c: oz., 10c; 1/4 lb., 30e; lb., sue; postpaid.

WINTER CROOK NFCK. Fruit long and crooknecked, skin dark green mixed with yellow. A nne keeper. Ikt., sc oz., 10c; $1 / 4$ 1b., 25c; lb., 75e: postpaid.

MARBLFWEAD. Resembling the Hubbard, but of a lighter color, and is remarkable for it sweetness, dryness and deilcions flavor. Good keeper. Pkt., 5c; oz., 10c: 1/4 Ib., 25c; 16., 75c; postpaid.

GIBLEY. (Plke' Peak.) Pear-ghaped with wem on large end, skin smoott. Jalo sroen; neali thick, orange color: very dry. rleh wud dellinge flavor. Pkt., 5c; oz., 10c: $1 / 4$ lb., L̈e: : Ib., 75e: postpaid.

Phelps Co., Nebr., Apr. 20, 1910.

Received seeds and bulbs in good condition yesterday. Can conscientiously recommend jour goods, as they have alway given the best of satiofaction, being especially adapted to this climate. A. L. POLHERNUS.

\section{Summer and Early Sorts}

One ounce to 20 hills; 4 to 5 lbs. to the acro. Hills 4 feet apart each way. I.

Ready for use in from 55 to 65 days from plant-

Any good enriched soll is adapted to the growth of the Squash. The seed should not be cown in the spring until danger from the frost is past and the ground is warm and thorouglily settled. Keep the earth abont the plants loose and clean. Three plants to the 1111 . For remedy against bugs see Insecticides. (Pages 70-71.)

FORDHOOK. Small, oblong, shell jellow, teah dry and sweet, and of good flavor. Very early: desirable for either summer or winier use. Plt., 5c: 0z., 10c: 1/4 lb., 30c: 1b., 85c; postpald.

GOLDEN BU\&II SCALLOP. A rery early, dat, scalloped variety; skin deep yellow; flesh pale yellow and well flavored. Pkt., bc; oz., 10c; $x$ ib., 25c: 1b., 60c; postpaid.

SUMMER CROOK NECK. Very early and productive. Fruit about one foot long, with crooked neck and warty surface; color bright yellow. Pkt., 5c; oz., 10c; 1/4 lb., 25c; lb., .60c.: postpaid.

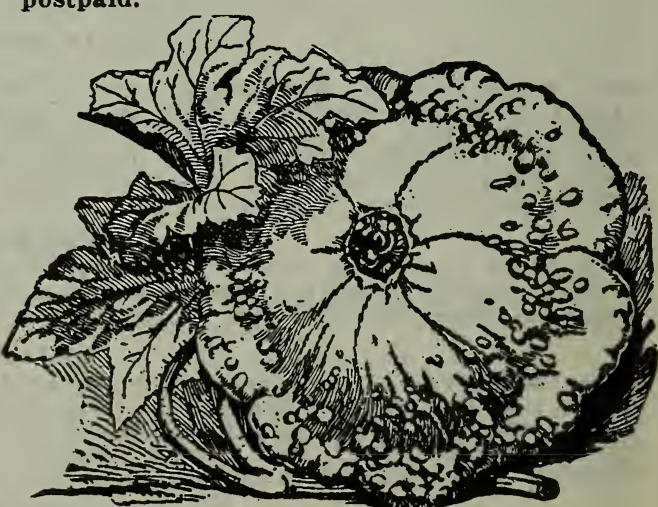

WHITE BUSH SCALLOP.

WHITE BUEH SCALLOP. .(Patty Pan.) Vory early, skin white, flesh tender and delicate, bears abundantly. Plt., 5c 0z., 10c; 1/4 1b., 25e: lb., 60c: postpaid. 


\section{Salsify or Vegeta- ble Oyster}

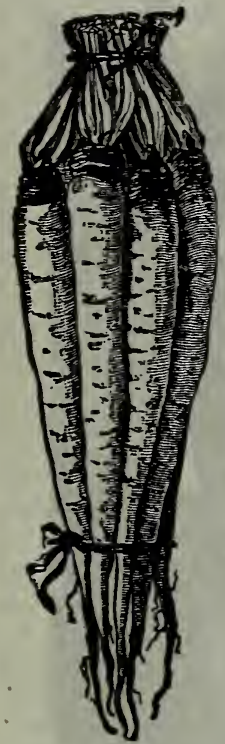

TAFER WURZEL

One ounce to 75 feet of drill.

Resembles a small parsnip, and when thinly sliced and cooked is a good substitute for oysters, having a rery similar flavor. It succeeds best in light, rich soll. Sow early and quite deep. The leaves when they first appear look like grass, making it specially important to plant in rows. Thin out and cultivate like the carrot, roots are perfectly hardy, and may remain out all winter, but should be dug early in the spring; store a quantity for winter use in cellar.

MA M M T H SANDWISH ISLAND. Grows untformly to an extra large size. The root is pure white and of superlor quality. Invaluable to market gardeners. Pkt., 5c; oz., 10c; $1 / 4$ 1b., 25c; 1b., 85c; postpaid.

\section{Swiss Chard or Sea Kale}

Far superior to the common beet for greens, of almost the same fiavor and equal to spinach. It is much easier to wash and prepare for the table. Sown early in the spring in rows, and the seedlings thinned out to 6 inches in the rows, It makes rapid growth of leaves, and is at for use for greens sooner than any other varlety, and can be cut throughout the entire summer. Later the leaves grow very large, with broad, flat, wax-like stems and mid-ribs, which may be cooked like asparagus or made into pickles. Pkt., 5c; oz., 15c; $1 / 4$ lb., 35c; lb., $\$ 1.00$; postpaid.

Mason Co., Mich., Mar., '10.

Your Corn Saver Beets are fine for cows. $I$ raised some 7 inches in diameter and about 20 inches long. MRS. AUGUSTA LARSON.

\section{Spinach}

\author{
SPINAT
}

One ounce to 100 feet of drill; 12 lbs. per acre. Cultivated very extensively for "greens." $\Delta$ profitable crop for market. Select a rich, welldrained soll, highly manured. For a succemilon, sow early in April and again in May, in drille on foot apart and one inch deep, properly thinnins out when the plants are an inch in the leaf. For early spring use, sow early in autumn and protect the plants with a light covering of leaves or straw.

BLOOMSDaLE. (Savoy.) The earliest of all and one of the best; the leaves are numerous, curled and wrinkled. Oz., 5c; $1 / 4$ lb., 10c; lb., 30c; pontpaid.

LONG-STANDING. (Thick Leaved.) A tne market sort. Leaves large and thick, somewhat crumpled. Does not run to seed early. Oz., 5c; $1 / 4$ lb., 10c; lb., 30c; postpaid.

PRICKLY. (Fall.) The hardest of all, therefore the best where the winters are severe. Oz., 5c; $1 / 4$ lb., 10c; 1b., 30c; postpald.

NEW ZEALAND. Entirely different from true spinach in type, in that it thrives during hot weather and in any soll, rich or poor. The tender shoots with golden yellow leaves are of good quality and may be cut throughout the summer. This is something new, but extra good. Plant three or four seeds in hill two feet apart each way. Pkt., 5c; 0z., 10c; $1 /$ lb., 25c; 1b., 85c; postpaid.

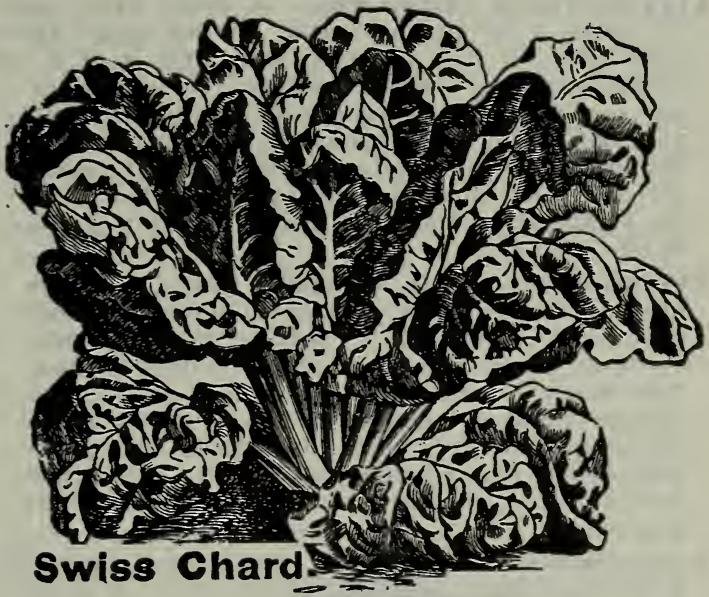

1 ounce to 2,000 plants. * 1b. (transplanted) per acre

\section{Tomatoes}

\section{LIEBESAPFET}

For Tomato Plants see Paze 14.

For early plants sow seeds in boxes or hotbed in March. When the plants are about two inches hish, transplant to four inches apart each way. Set out of doors as soon as danger from frost is orer. Transplant carefully four feet apart each way, and cultivate well as long as the vines will permit. To obtain early fruit, pinch of the ends of the branches when the arst fruit is set.

\section{SMALL TOMATOES}

Used for preserves, pickles, and to make "tomato figs."

Postpald Prt. Or. $\$ 0.0580 .20$

reLLOW PFAR. Bright jellow color; flesh yellow and fine flavored

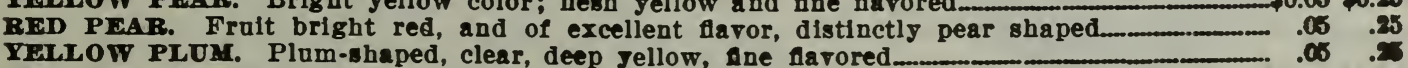
YRLLOW CERRRY. Same as Red Cherry, except color KRLCOW PFACH. About 11/2 inches across; skin like a peach, and plak .25

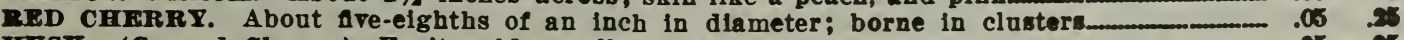
HUSK. (Ground Cherry.) Fruit golden jellow, size of cherry 
DWARF CHAMPION. (Tree Tomato.) A great favorite. Extra early dwarf and compact in habit, the plant growing stiff and upright, fruit smooth, medium sized, purplishpink. Pkt., 5c; oz., 25c; 1/4 lb., 75c; postpaid.
EARLIANA. It is a full week ahead of all others. Plants of strong growth and very productive. Fruits large, deep red, and of superior quality. Smooth and free from cracks. Pkt., 5c; oz $25 \mathrm{c} ; 1 / 41 \mathrm{~b} ., 75 \mathrm{c}$; postpaid.

CRIMSON CUSHION. (Beefsteak). Fruit very large, round and regular; bright scarlet; flesh solid and of the best quality; rely productive. Pkt., 5c; or., 25c; 1/4 1b., 75c; postpaid.

CHALK'S EARLY JEWEL. The largest, smoothest, and finest flarored, early bright red tomato, so hardy that a very early planting can be made in the open ground. The foliage protects the fruit, borne in clusters, from sun-scald enabling the heavy crop to ripen perfectly. The tomatoes are bright scarlet, deep globe shapé, large and solid. Produced continuously throughout the season. Pkt., 5c; oz., 25c; 1/4 lb., 75c; postpaid.

DWARF STONE. Livingston's. Very early and productive; in size, color and quality of fruit equals the Stone; in habit of vine resembles Dwarf Champion, but is stronger and more erect, admitting very close planting. Pkt., 5c; 0z., 25c; 1/4 lb., 65c; postpaid.

JUNE PINK. An extra early purple-fruited tomato similar to the popular scarlet-fruited Earliana in growth of vine, shape and size of fruit and time of maturing. Pkt., 5c; 0z., 25c; 1/4 lb., 80c; postpaid.

LIVINGSTON'S HUMMOR. It is as round as a ball, and as there is very little indenture about the stem, there is practically no waste in preparing the fruits for use. The flesh is rich crimson scarlet and of a very fine quality. Ripens early, and is especially good for canning. Not quite as large as some varieties, but a good keeper, thus making it a good variety for market. ing. Pkt., 5c; oz., 30c; $1 / 4$ lb., 95c; postpaid.

LIVINGSTON'S CORELESS. A new, large main-crop variety. In shape it is almost round, having about the same diameter each way. It has no green core, and is of a bright red color, making it very valuable either for slicing or for canning. It is immensely productive and the firm, solid flesh makes it one of the best for long distance hauling or shipping. It ripens all over and through and up under the stem all at the same time. Pkt., 5c; 0z., 35c; $1 / 41 \mathrm{~b}$., $\$ 1.00$; postpaid.

LIVINGSTON'S NEW GLOBE. Beautiful globe shape, permitting a greater number of slices than with flatter sorts. Among the very first to ripen, large size, very smooth, firm fleshed, few seeds, ripens evenly; color rose, tinged purple. Flavor excellent. The fruit is borne on short, jointed branching plants in great abundance. A good general cropper; one of the best for forcing. Pkt., 5c; oz., 25c; 1/4 lb., 75c; postpaid.

PONDEROSA. Of immense size, solid, meaty, almost seedless, pinkish, purple, and of good flavor, late. Pkt., 5c; oz., 30c; 1/4 1b., \$1.00; postpaid.

\$TONE. Large, perfectly smooth; bright scarlet; ripening even to the stem without a crack; very solid and heavy. The standard main crop variety. Pkt., 5c; 0z., 20c; 1/4 1b., 65c; postpaid.

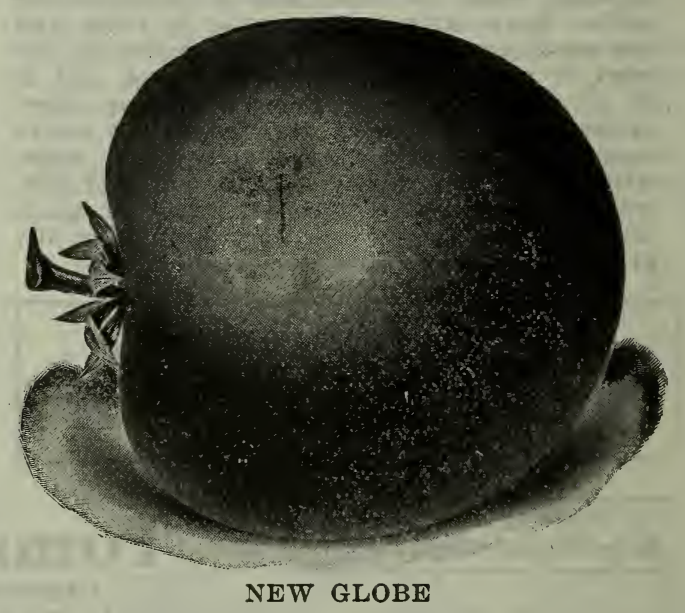

\section{OTHER STANDARD VARIETIES}

All Postpaid

Pkt. Oz. 1/4lb.

ACME. Bright pink; smooth, round, early, productive and popular

$\$ 0.05 \$ 0.20 \$ 0.65$

BEAUTY. Large, smooth, purplish pink, thick flesh; regular form

ENORMOUS. Color deep red, smooth, solid meat, and a few seeds.

FAVORITE. Large, smooth, productive; à good shipper and canner..................................... $\quad .05 \quad .20 \quad .60$

GOLDEN QUEEN. The best, large, smooth, yellow tomato; finest quality....................... $\quad .05 \quad .25 \quad .75$

QUARTER CENTURY. Very early. Like the Dwarf Champion. only bright red........ $\quad .05 \quad .25 \quad .75$

TROPHY. Large and bright red, solid, smooth; a great yielder................................................ $\quad .05 \quad .20 \quad .60$ 
Ready from 40 to 60 days from seed.

\section{TURNIPS REUBEN}

1 oz. to $150 \mathrm{ft}$. of d rill 2 lbs. to acre.
The simplest method of keeping root crops in good condition for winter use. Store in cool celıar in boxes, etc., and cover with dry sand or fine soil, thus excluding the air. They will keep as solid as when freshly dug, and are ready for use at any time.

The turnip is most easily affected in form and flavor, by soil, climate and mode of culture. Sow in drills about 16 inches apart and half an inch deep, or sow broadcast, but in either case be sure to have the ground rich and freshly dug. Sow for main crop from the middle of July to the last of August. In the field, turnips are generally sown broadcast, though much larger crops are obtained by drill culture.

EXTRA EARLY PURPLE TOP MHLAN. TWO weeks earlier than any other. Flat; white, with purple top, flesh white, fine grained and dellcate. Pkt., 5c; 0z., 10c; $1 / 4$ lb., 20c; lb., 60c; postpaid.

EXTRA EARLY WHITE MLAN. Similar to above, but pure white. Pkt., 5c oz., 10c; 1/4 1b., 20c; lb., 60c; postpaid.

FARLY PURPLE TOP GLOBE. Deservedly popular, heavy producer, of rapid growth, and superior quality; either for the table or stock. An excellent keeper. Pkt., 5c; oz., 8c; 1/4 lb., $20 c$; 1b., 45c; postpaid.

PURPLE TOP STRAP LEAF FLAT. The old, well-known sort for early spring and fall; purple above ground, flesh fine grained, of mild flavor and a good keeper. Pkt., 5c; 0z., 8c; 1/4 1b., 20c; lb., 45c; postpaid.

WHITE EGG. An egg-shaped variety, for spring or fall sowing; flesh white, firm, fine grained, mild and sweet; particularly desirable for table. Pkt., 5c; oz., 8c; 1/4 1b., 20c 1b., 50c; postpaid.
EARLY WHITE SNOWBALL. (Six Weeks.) A perfect globe-shaped, white-skinned turnip. A good keeper; fine for family or market. Pkt., 5c; oz., $8 c$; 1/4 1b., 20c; lb., 50c; postpaid.

EARLY WHITE. FLAT DUTCH, STRAPLEAVED. A fine early white sort, of quick growth and good quality. Pkt., 5c oz., 8c; $1 / 4$ lb., 20c; 1b., 45c; postpaid.

LARGE YELLOW. (Amber Globe.) Flesh yellow, fine grained and sweet; very hardy and productire, splendid keeper. Pkt., 5c; oz., 8c; $1 / 4$ 1b., 20c; 1b., 45̃c; postpaid.

GOLDEN BALL. (Orange Jelly.) Yellow fleshed; a rapid grower, of tine flaror. Pkt., 5c; oz., sc; $1 / 1$ 1b.. 20c; 1b., 4うc; postpaid.

POMERANIAN WHITE GLOBE. Very productire; in good soil roots grow from 10 to 12 poundsffi good for table or stock. Pkt., כ̃c; oz., Sc; $1 / 4$ lb.. 20c; lb., 45c; postpaid.

COW-HORN. A white turnip of peculiar long shape and quick maturity. It grows to a large size, standing half out of the ground. Pkt., 5c; oz., 8c; 1/4 1b., 20c; lb., 50c; postpaid.

\section{Ruta Bagas or Swedes}

Should be sown about a month earlier than turnips.

AMERICAN PURPLE TOP. TOps very small; bulbs large; skin purple above, yellow underneath; flesh golden yellow, fine texture, sweet and of richest flavor; hardy, productive, and a good keeper; desirable for table use and stock feeding. Pkt., 5c; 0z., 8c; $1 / 4$ 1b., 15c; 1b., 40c; postpaid.

SKIRVING'S PURPLE TOP YELLOW. Quite productive; flesh jellow and sweet flavor, shape oblong. Pkt., 5c; oz. $8 c ; 1 / 4$ lb., 15c; 1b., 40c; postpaid.

SWEET GERMAN. (Long White French.) Bulb enormous. Flesh white, solid and rich. The best keeper of all the Swedes, and popular for both table and stock. Pkt., 5c; oz., $8 \mathrm{c} ; 1 / 4$ lb., $15 \mathrm{c}$; 1b., 40c; postpaid.

\section{Tobacco}

One ounce will sow about 25 square feet and produce plants for one acre.

CONNECTICUT SEED LEAF. An old, well-known variety. Pkt., 5c; oz., 20c; 1/4 1b., 60c; postpaid.

HAVANA. Best for the manufacture of cigars. Pkt., 5̃c; or, $20 \mathrm{c} ; 1 / 4 \mathrm{lb} ., 60 \mathrm{c}$; postpaid.

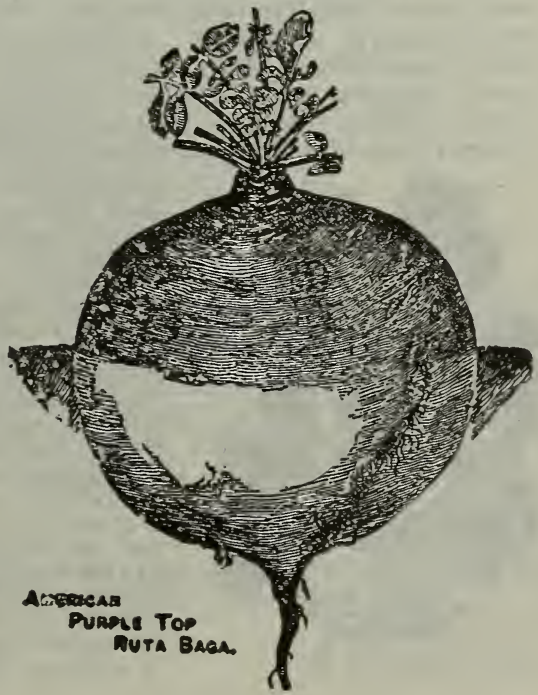




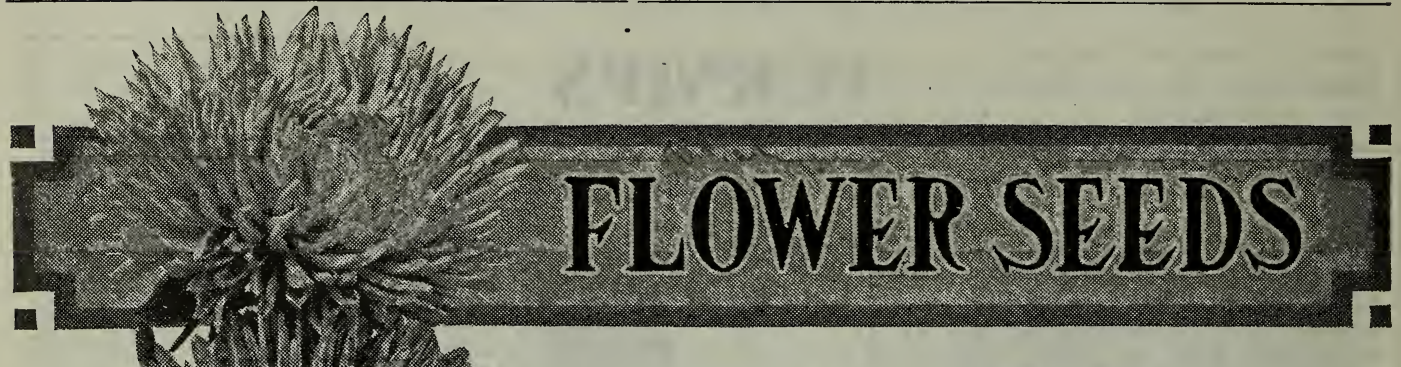

IT WILL PAY YOU TO READ THE FOLLOW-

ING CAREFULLY :

General Culture.-A rather light and moderately rich soll thoroughly spaded, is most desirable. That the tiny seedlings may be seen and the weeds removed, it is better to plant all flower seeds in rows. Sow the seed evenly in the rows, cover with the finest of soil, about three times the diameter of the seed, and press the soil firmly orer the seed. The soll should never become dry after the seeds have swelled, for if it does, they will be pretty sure to fail. Do not grow the plants too thick. Keep the weeds down and the surface of the soil well stirred with a hoe or rake durins the summer, especially if the weather is dry. A great many varieties can be sown in the house, if desired early, and afterwards transplanted. Most plants will continue to bloom much longer if the flowers are picked, and not allowed to form seed. Discount: Any 6 of our Large sc Packets for 26.

RULE FOR PLANTING

Cover seed three times the depth of seed planted. Keep covered with cloth or paper till sprouts appear.

\section{SEEDS OF ANNUALS}

In this department we Include both annuals that bloom and die the first jear, and such peren. aials as flower freely for the irst jear.

For other vines, wee Page 61.

For house plants, see Page 53.

For other perennials, see l'age su'

ICROCLINIUM. Daisy-like, everlasting flowers; plnk and white with jellow center.

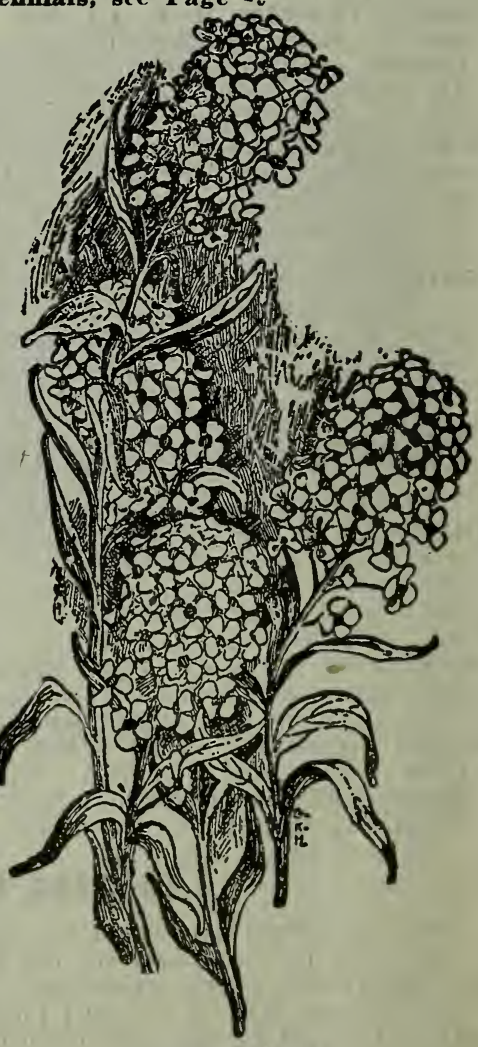

ALYSSUM, SWEET.

AGERATUM. One of the best border flowers, blooming all summer; of easy culture. Grows 5 inches high. Blue or white...5.

AGROSTRMMA. (Rose of Heaven.) Attractive pink-like bloswoms on long, slender stems. Very pretty in masses. Perennial..5c

ALYSSUM. Profuse bloomer, good for bordering or for bouquets, Ine for window boxes. Sow very early

sweet. Fragrant white flowers. The old favorite. Iittle Gem. Dwarf and compact. Good for border

Onerpet of snow. VerJ dwarf tralling plants.

AstiRS. (For aster plants see page 53.) One of the most popular of our garden flowers for late summer and fall display. Sow seed early and give deep soll with plenty of mulch.

Hohenzollorn. Improved. The flowers are very large and double, with long, curled petals on long stems, very graceful. White, pink, lavender, purple and mixed

Giant Comet. (See cut at top of page.) A beautlful, distinct varlety, resembling chrysanthemums. Mixed..................................

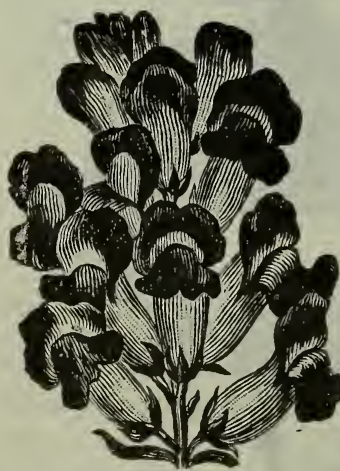

ANTIRRHINON

Branching. Large, late-blooming, with long, strong stems. Mixed colors......5c Betteridge Qulled. Flowers large, freeiy prouluced, and of brilliant colors height, 12 inches. Mixed, all colors...5 Truffaut's Peony Perfection. Large and perfectly double, with beautifully in curved petals, giving the flowers globular form. Mixed colors _._._. Chrysanthemum Dwarf. 9 Inches high. Good sized flowers, free bloomer. Mixed colors.

AMARANTHUS. Rapid growing. brishtcolored follage plants. Sow seed early and set out in rather poor soll to set best effects

ANTIRRHINUM. (Snapdragon.) Dark glossy leaves and beautiful spites of flowers, with inely marked throats; one of the most showy border plants. ne easiest culture. 
Queen of the North. Large, fragrant, white now. ers. Nice for pot-culture as well as borders_bc Tall Sorts, Mixed. All shades of red and yellow; best for cutting.

Dwarf Sorts, Mixed. Large varlety of colors: best for edging

BALSAM. (Lady's Slippers if Touch-Me-Not.) To grow these to perfection, start the seed in the house or hotbed, transplanting to very rich soll in the garden. Transplanting them two or three times has a tendency to dwarf them and make them more double.

Camellia-Flowered. The best of all balasms. Flowers very large, perfect in form, double and produced in abundance. Mixed colors._...

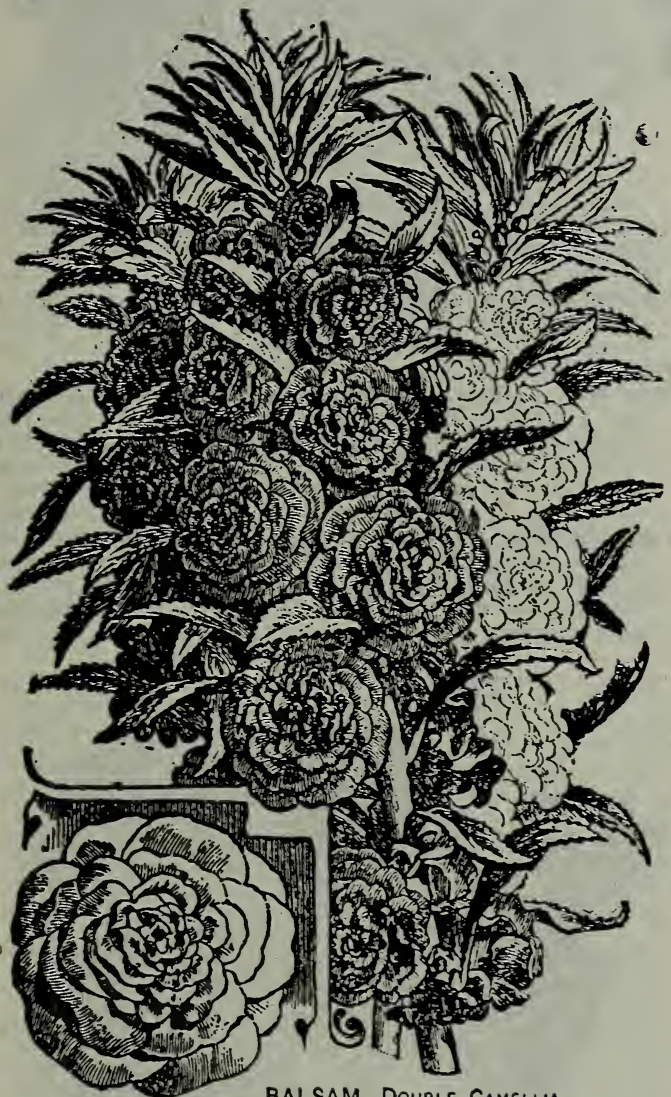

BALSAM, DOUBLE CAMELHA

BACHELOR'S BUTtON. See Centaurea Cyanns

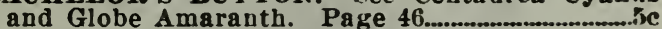
BUTTERFLY FLOWER. See Schizanthus. Page 43

CACALIA. (Flora's paint brush.) Small, tassellike flowers. Golden yellow and scarlet............ic CALENDULA. (Pot Marigold.) Tery free and attractive bloomers. Donole, all shades of Jellow

Castor Bean. See Ricinus, Page 42.

CANDYTUFT. A dwarf-growing annual. making a striking display early in the season Suw early where plants are to bloom. (Irowg one foot bigh.

Empress. A complete mass of pure white finw. ers. Valuable for bouquets

Fine Mixed. Red, pink and white...........5c

CANNA. (Indian Shot.) Stately plants with handsome foliage and howy flowers. The seeds should be soaked 24 hours in warm water before planting. If sown in February should bloom in July.

Large Flowering French. Saved from best and largest flowers only. All color. CELOSIA. Plamess. About two feet high, of branching habit, with feathery plumes of brilliant red; one of the most effective ornamental

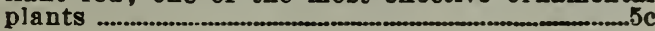

Cristata. (C o c.k scomb.) Free bloom. ing $d w a r$ plants producing spikes of comb-shaped flow. ers

C A L L I O P S I S. A showy plant, producing flowers of zellow, red and brown. Sow quite early, and thin to 6 inches a part. Mixed $5 \mathrm{c}$ CENTAUREA. These old-fashloned flowers are fine for borders. Cyanus. (Bachelor's Button.) Also called Blue Bottle, Ragged Sallor and Corn Flow: er. Is a hardy an. nual, coming up jear after year from selfsown seed. Mixed...5 Emperor. I n te n se blue

Gymnocarpa. (Dusty Miller.) Graceful one. cut, silvery white folinge. Nice for edging beds...non............. Imperialis, (Sweet Sultan.) D o u b l e sweet-scented flowers borne on long, stout stems, Keeps for \& week in water, if cut Just when about to open: white, lilac. rose and purple, $2 \mathrm{ft}$. high. Mixed..............

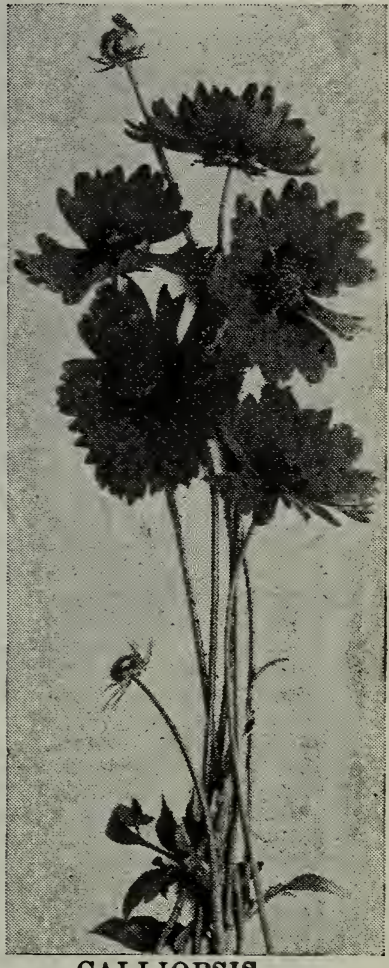

CALLIOPSIS
CHRYSANThemUM. Annual. Distinct from the pot plant varieties, blooming all summer. All shades of yellow. Choice mixed.

CLARKIA. Very pretty free flowering annuals, desirable for shady places flow CLEOME. Pungens. (Giant spider Plant.) Rose colored flowers with long stamens. A tall grower, and blooms freely until frost..................5c

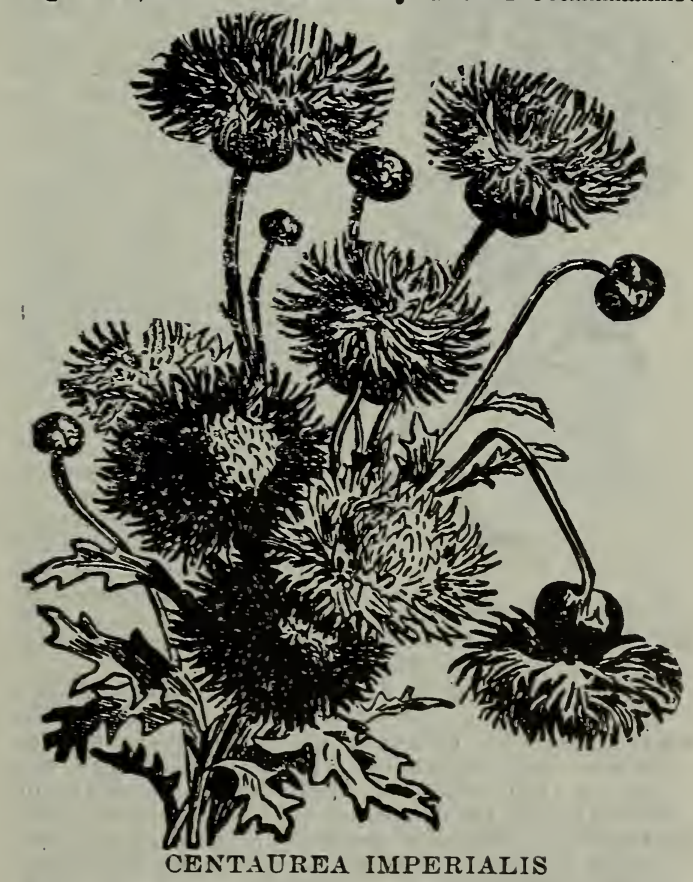

FOR FERTILIZER IN THE FLOTER BEDS USE "SIVARD FOOD." PAGE 69 


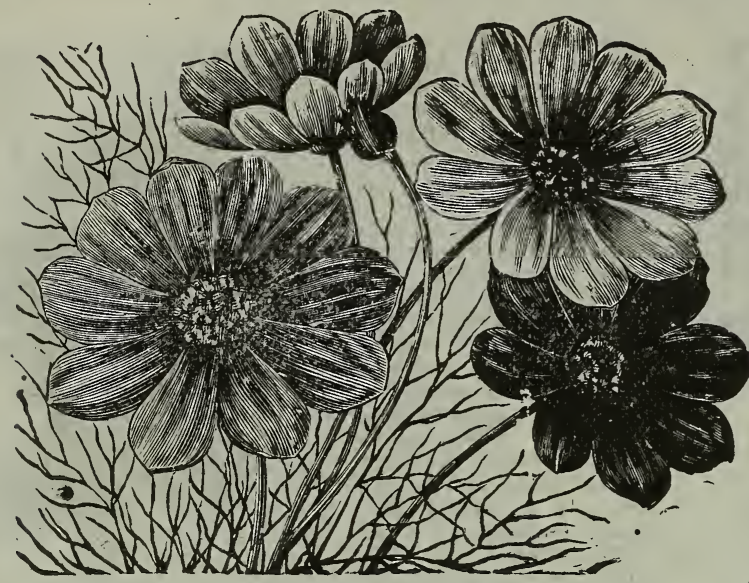

ESCHOL TZIA

California Poppy $\mathrm{S}$ o-w early, where it is to remain, as it will not bear t r a n s l anting. The foliage is finely cut and handsome and the flowers are $\boldsymbol{v}$ e $r$ showr large and free. ly produced. Californica. All shades of $\mathrm{yel-}$ low FOUR O'CLOCI. (M a r v l of $\mathbf{P}$ e u.) $\mathrm{Th}$ e fragrant flowers, produced in $\mathrm{clu}$ s te $\mathrm{r} \mathrm{s}$,

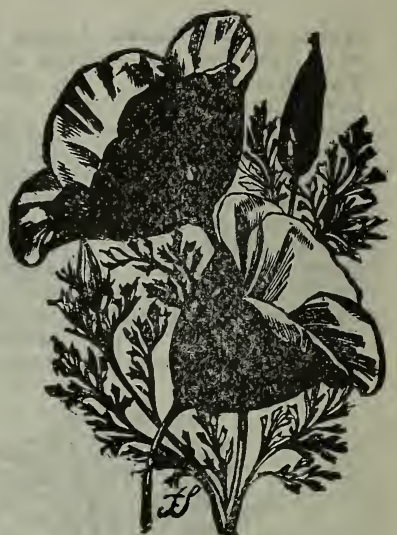

CALIFORNIA POPPY open in the afternoon. Mixed. $5 c$ GOLDEN FEATHER. (Pryethrum Aureum.) Finely cut leaves of bright golden yellow color, Extra fine for bedding. Perennial..........................5c

GYPSOPHILA. Thrives everywhere and furnishes light and grace to a bouquet. The tiny white flowers are on branching stems.................................5c HELIANTHUS. See Sunflower. Page 42.

KOCHIA. (Burning Bush or Summer Cypress.) The plants grow with many slender branches resembling a small, closely sheared evergreen with light green leaves until fall when the whole plant turns crimson. Seed germinates readily. Sow May 1, and thin to $2 \mathrm{ft}$. apt. $21 / 4 \mathrm{ft}$. high..5 c

LARKSPUR. Hyacinth flowered. The flowers which resemble a double hyacinth, are borne freely in long spikes of blue, pink and white. The plants are of dwarf habit. Sow. where the plants are to bloom....................................................5e forms and will give a great profusion of bloom Dawn. An early flowering strain in which all the flowers are white with just a touch of delicate pink at the base of the petals

DATURA. (Sweet Nightingale.) A large, strong growing plant, with trumpet-shaped, fragrant, pearl-white flowers.

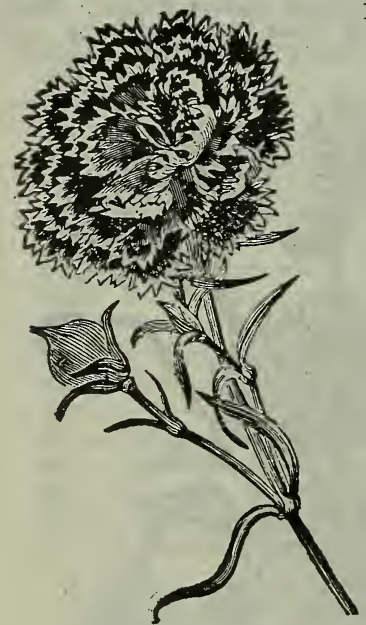

DIANTHUS. of value for bedding. The colors range from pure white to the richest crimson, spotted and striped. Perennial but bloom the first summer, and for years, if the flowers are freely picked.

Chinensis. (Double Chinese or Indian Pinks.) Com p a ct plants with large clusters of $\mathrm{dou} \mathrm{b} \mathrm{le}$ flowers. Excellent for bouquets as well as bedding ........................5c Heddewigi. (Double Japan Pinks.) Much larger than the Chinese pinks.........................5c Heddewigi Fireball. Brilliant scarlet...5c Heddewigi Snowball. Pure white................5c

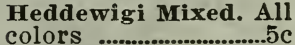
Heddewigi Midnight. Blood red...........................5c

EVERLASTINGS-(See Acroclinium, Celosia, Globe Amaranth, Gypsophila.)

Pick when flowers first open and hang, stems up, to dry for winter bouquets.............................5c

Gaillardia. (Blanket Flower.) Picta Lorenziana. The heads of star-shaped flowers are greatly admired for their rich blending of colors; red, yellow, orange........................................5c

GODETIA. Beautiful garden plants, having delicately shaded, large, trumpet shaped blossoms. Easily cultivated in any good garden soil........5c GLOBE AMARANTH. (Gomphrena.) Sometimes called Bachelor's Button. A very pretty everlasting flower with blossoms resembling clover. Mixed

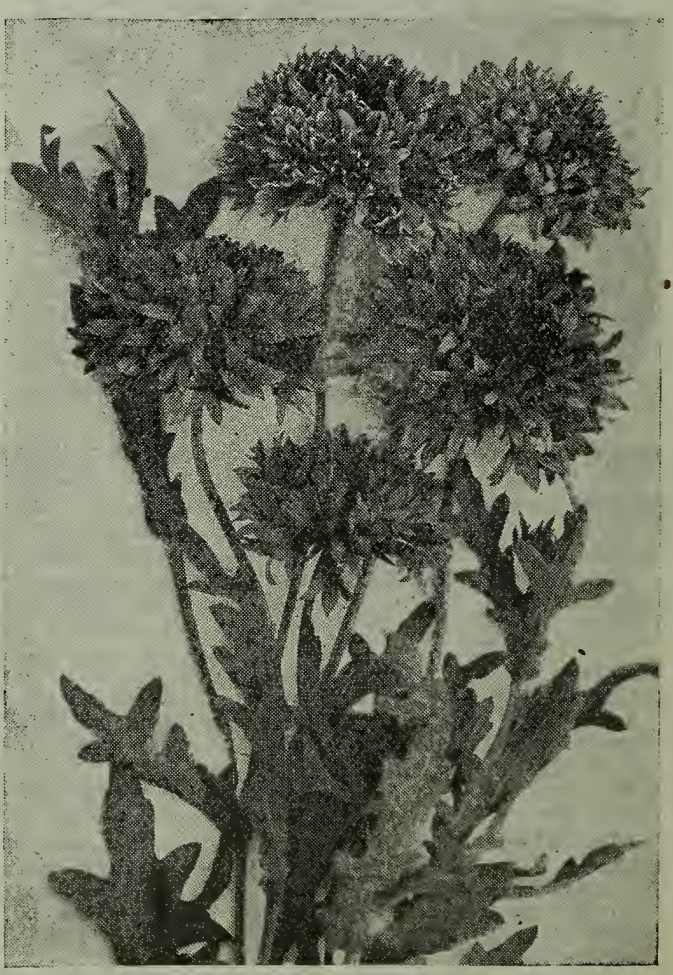

GAILLARDIA

Lobecia. Crystal Palace. Charming little plants that bloom very quickly from seed and continue all through the season. Deep blue, 6 inches high. Very nice for bedding or for borders .................................................................................... 
MARIGOLD. Wherever a rich displas of bloom is desired, the Marigold is almost indispensable.

African. Immense flowers, double; all shades of yellow........................................................................... French. Dwarf grower; double flowers, rich golden yellow marked with relrety brown.......... c

MGNONETTE. (Reseda Odorata.) A well known fragrant favorite; in bloom the whole season if gathered freely. Large flowering.........5c

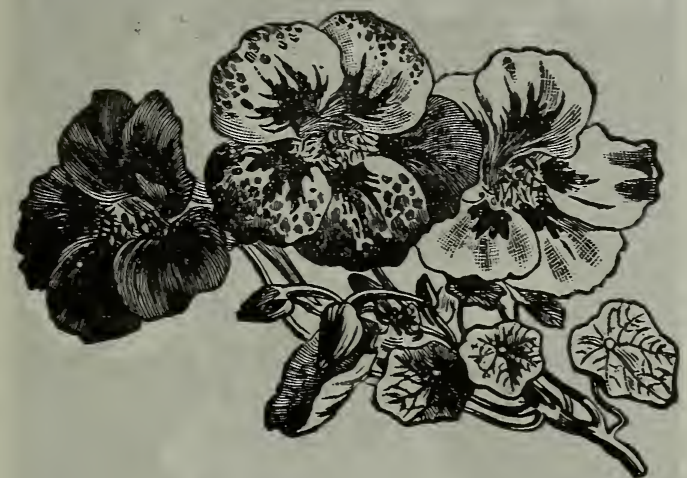

NASTURTIUM. Dwarf or Tom Thumb. A beil of dwarf nasturtiums in the yard is ver 5 brilliant and attractire, blooming all the season. 1 foot high.

Beauty. Scarlet, splashed canary.......................... c Chamaleon. 'Mottled crimson, bronze and yel-

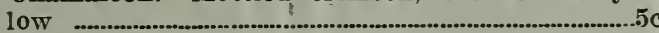
Crystal Palace Gem. Sulphur with maroon spots ............................................................................ Golden King. Deep yellow flowers............................5c Golden Queen. Leaves golden-green, flowers orange yellow.

King of Tom Thumbs. Bright, red, dark foli. age

Scarlet King. Brilliant scarlet....................................5c Mixed, oz. 10c.

NICOTIANA. Affinis. Deliciously fragrant, large white, star-shaped flowers; open at erening and early morning; easily grown, blooms freely in the house.......................................................................5c Sanderae. Sweet scented, brilliant red flowers or sturdy, bushy plants 2 ft. high; grows readily from seed.

NIGELIA. Miss Jekyll. (Love in a Mist.) The plants are vigorous and give an abundance of flowers of the clearest blue, contrasting most charmingly with the fine, fern-like foliage.......5

PANSIES. For started plants see page 53. The seed may be sown in the not bed or open ground. Keep the soil moist. They prefer a half shady place. Do not let the plants seed if you wish to keep them in bloom. If sown in the fall, pansies will bloom very early in the spring.

Masterpiece. (Giant Curled.) The fluted petals make the enormous flowers appear double. The colors and combinations are odd and strik.

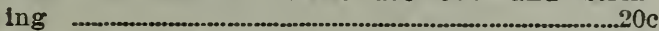
Mammoth Butterfly. The flowers are rery large. The colors are rich red, chocolate, and purple shades, mottled and spotted....................15 Bugnot. The flowers are large, with broad blotches, and delicate pencilings to the edges of the petals.

...10c Odier. The blotched, or five-spotted variety.

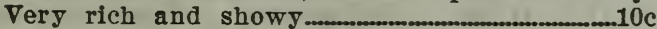
Fancy Striped. A striking mixture....................

PANSY SPECIAI-No. 19. One Packet each of Bugnot, Mammoth Butterfy and Odier 25c.

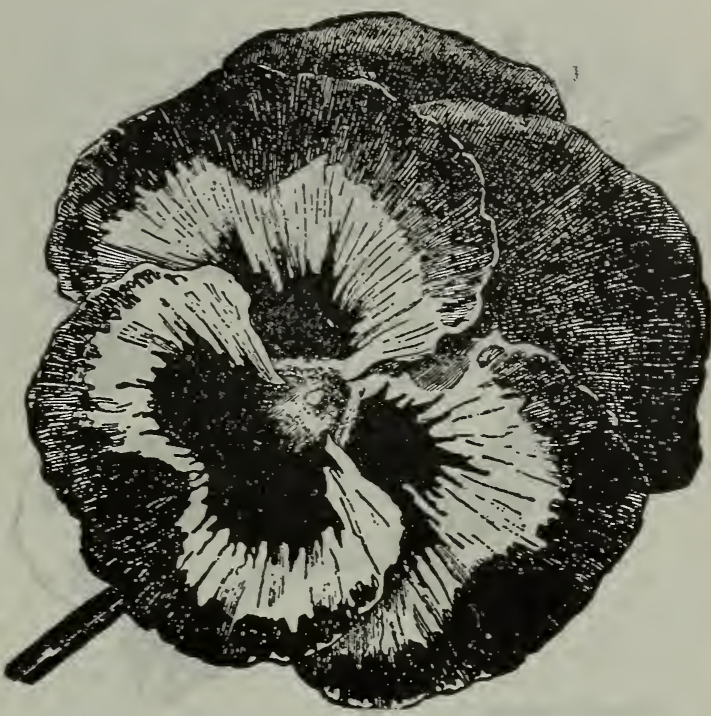

Giant English Show. Splendid mixed from the largest named flowers only............................2.5c Fine Mixed. A rery good quality.........................5c Giant Adonis. Light blue..........................................5c Giant Atropurpurea. Dark purple..........................5c Giant Bronze. Shades of bronze................................ Giant Cardinal. Brilliant red....................................... Giant Emperor William. Dark Jlue.....................5c Giant Goldelse. Yellow...............................................5c Giant King of Blacks. Beautiful blacks.............5c Giant Snow Queen. Pure white................................. Special Giant Mixture. An excellent combination of fancy strains, selected with a view to being as near perfection as possible.....................10c

PANSY SPECIAL-No. 14. 1 pkt. of each of the next above 8 Giant named colors $30 \mathrm{c}$

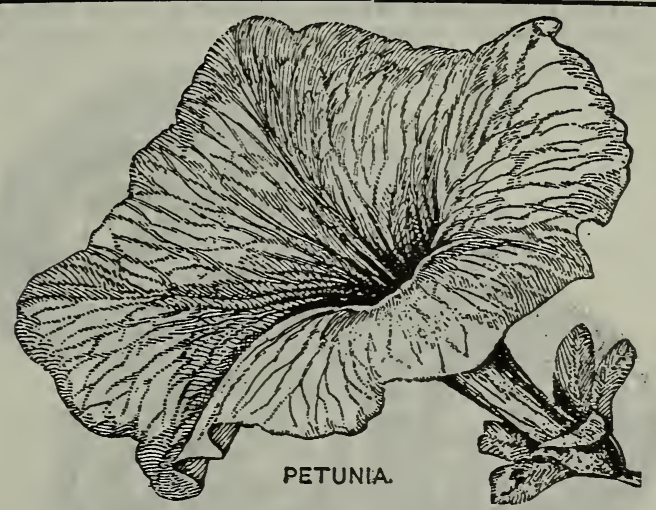

PETUNIA. Petunias are very popular for their rich coloring, continuation of bloom, pleasing fragrance, and easy culture. Can be sown in the open border, in full sun or partial shade. Transplant easily, 11/2 feet high.

General Dodds. Beautiful; velvety, dark red..̄̌c Snowball. Compact growing, pure white, blooms all summer............................................................5c Howard's Star. Rich, velvety, maroon with a white blotch on each petal.

Fine Mixed. An excellent mixture........................... Giant Ruffled and Fringed Single. The flowers are exquisitely ruffled or frilled, of immense size, and of great varieties of colors....................10 Double Mixed. Sure to produce a good percentage of double flowering plants......................20 


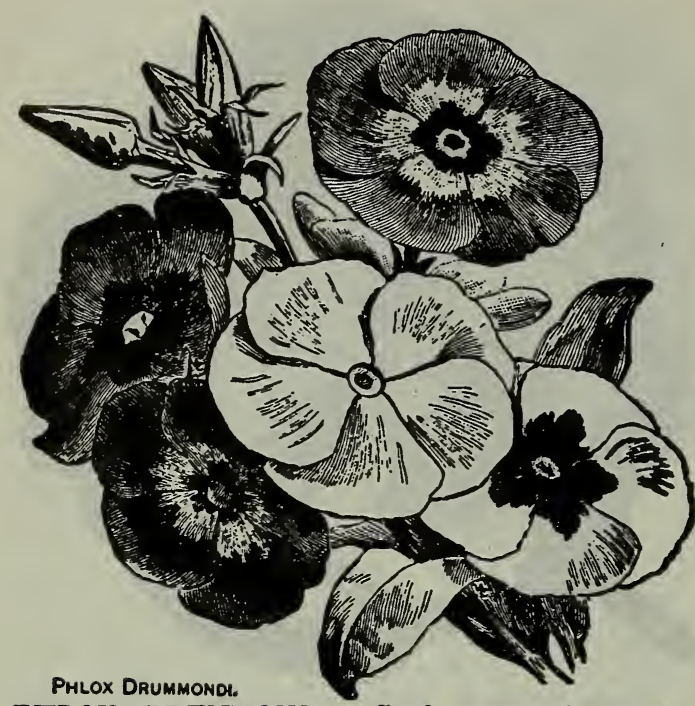

PHLOX DRUMMONDI. Seed sown in open ground in early spring will begin flowering about July first and bloom until frost. Thrives in almost any situation. For masses of separate colors or for bouquets they are unsur. passed. One foot high.

Alba. Pure white.

Scarlet. Very showy.

Rosy Chamols. Beautiful shade of rose............ Extra Cholce Mixed. Best large flowered.......... Jc Starred and Fringed. Very dwarf flowers fringed and distinctly edged with white. Mixed

PnPPIES. These exceedingly showy and easily cultivated plants grow and bloom well in ordiuary soil. Sow the seeds where the plants are to grow, as they do not bear transplanting. Tulip. Cup-shaped, brightest scarlet, with black spot at base of each petal. Single...........5c Paeony-Flowered Mixed. Splendid large double towers of all colors.

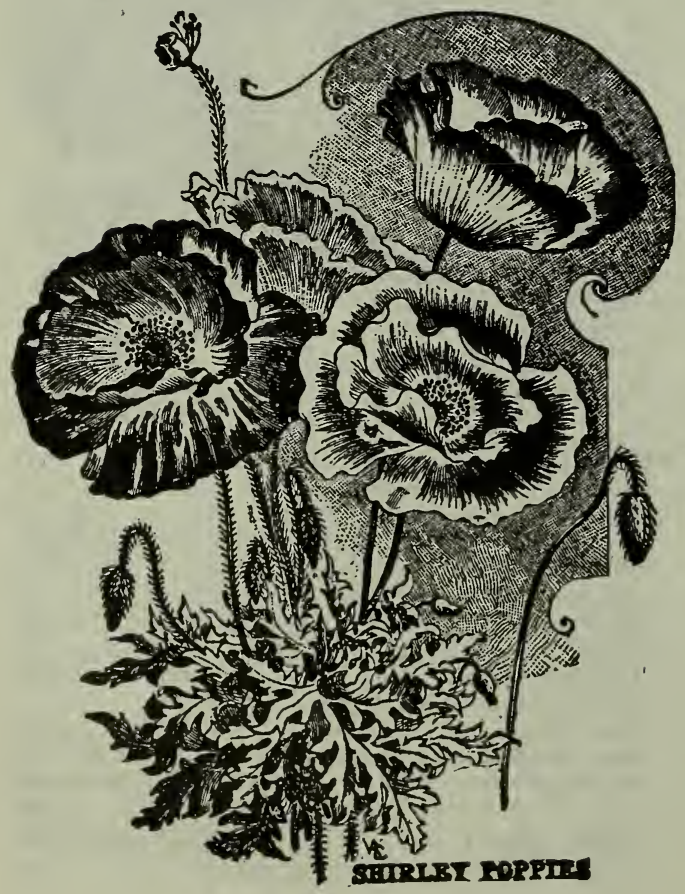

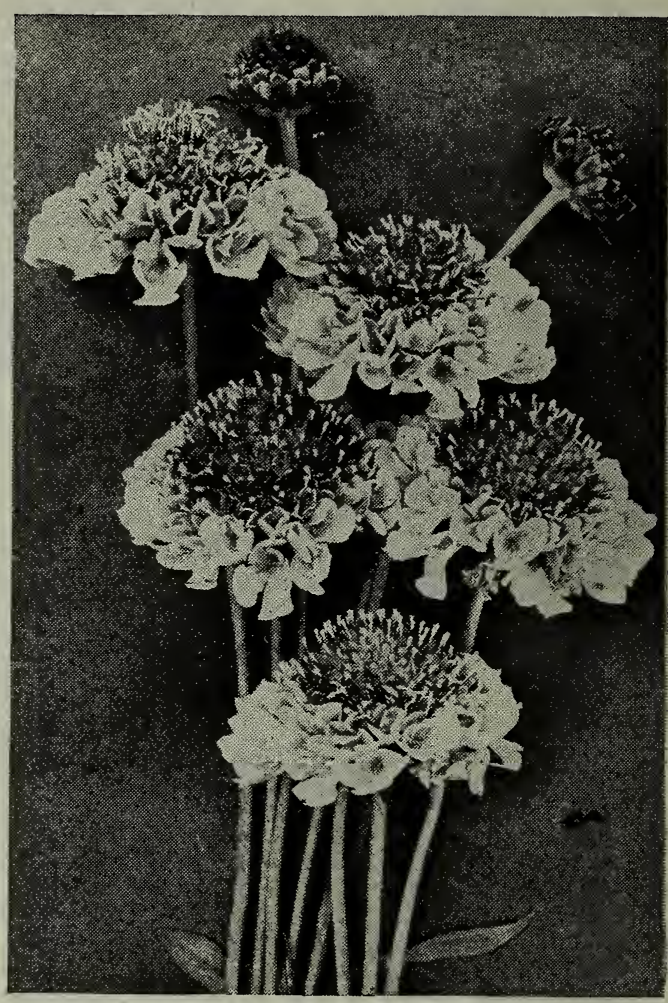

SCABIOSA

Shirley. (See outside cover.) Pink, carmine and brilliant crimson; many edged with white;

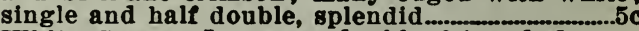
White Swan. Immense double fringed flowers

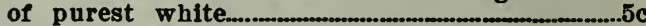
Carnation-Flowered. Brilliant, flnely fringed double flowers of various colors..........................

PORTUlaCa. (Rose Moss.) Brilliant dware annuals, blooming profusely from early summer to autumn. For low beds and masses of color the are very desirable. They thrive best in rather rich, sandy soil and a sunny situation: will stand any amount of dry weather.

single Mixed. All colors

Double Mlxed. Not all the plants will come double, but the single ones can be pulled out

RICINUS. (Castor Bean.) Semi-tropical plants grown for their great size and picturesque foliage; colors range from bright green to dark red. One plant or a dozen make an admirable sight for a long distance. 6 feet to 10 feet high

SCABIOSA. (Mourning Bride.) An old favorite greatly improved. Excellent for bouquet.

Tall German Double. Mixed, all colors...............5c Black Prince. Very large, rich dark maroon..5c Snowball. Elegant, white flowers, sure to be liked, for vases and bouquets. SALVIA. Splendens, (Flowering Sage.) For started plants see page 53. Among the most brilliantly colored of garden flowers and extremely useful for bedding; also valuable for pot culture. Blooms are borne in long spikes of flery red, and continue in bloom until severe frosts. Start in house and transplant into light soil. Tender perennials, 2 to 3 feet tall.....5c SUNFLOWER. (Helianthus.) Adapted by it tall, vigorous growth for a background.

Mammoth Russian. Of immense size, single....oc Californicus. Extra large and very double......5c

SCHIZANTHUS. (Butterfy Flower.) Flowers are pretty and freely produced. Purple, Jellow

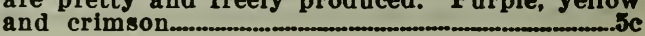




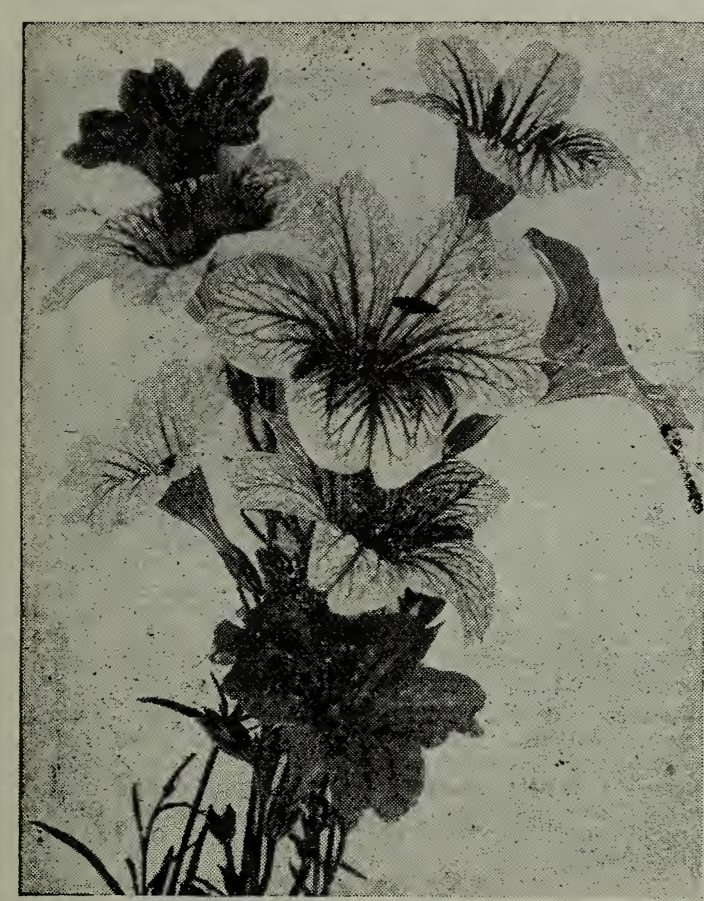

SALPIGLOSSIS

BALPIGLOSSIS. (Velvet Flower.) Strong, erect plants with curious, funnel-shaped flowers of rich colors. Plant in warm, rich soil; among the best fall flowers. 11/2 feet tall.......... be SNAPDRAGON. See Antirrhinum, page 38 .

STOCK. German Ten Weeks' Perfection. Very desirable because of its brilliancy of color, pro fusion and duration of bloom. Fragrant, with large double rosette-like flowers. Mixed.........10c Princess Alice. Snow white. Of branching habit. Very profuse bloomer, especially if kept cut ......................................................................................

VERBENA. (For started plants see page 53 .) For beds or massing the verbena is unrivalled; flowers of the most brilliant colors. Sow them early and they will bloom profusely from June until winter.

Deflance. Rest scarlet.........................5c Alba. Pure white

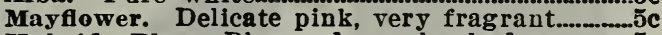
Hybrida Blue. Blue and purple shades................ Choice Mixed. All colors..................................5c

WALLFLOWER. Single annual. Very fragrant; flower. Seed sown the first of May will bloom from July until severe frosts. It is very satis. factory as a pot plant for winter, if kept in a cool room

zINNIA. Flowers all summer, making the most brilliant display possible, excellent for border or summer hedge. Seeds grow easily, and joung plants transplant safely.

Giant Flowering. Plants of vigorous growth, about three feet high, bearing profusely their perfectly formed double flowers, mixed colors $5 \mathrm{c}$ Dwarf Fireball. Glowing, brilliant scarlet._.5c Zebra. Flowers striped with red and yellow...5c White Gem. Small, double white flowers _.......5c

\section{Seeds of House Plants}

These can readily be grown if given careful attention. For winter blooming, plant during the spring or summer, in shallow boxes, in mellow soil about one-fourth sand. Sow the seed on the surface, and cover with a very little more soil; water carefully, cover with a pane of glass and keep dark until the seeds germinate, then light and air should be admitted by removing glass, partially at first. Place the box in the sun and transplant when large enough.

Chrisanthemum. Perennial. Japanese and Chinese large flowering. These are for pot cul. ture, for blooming in the house in winter. If sown early, will flower the first year. Double mixed.

coLEUs. The best known of ornamental foliage plants with richly-colored leaves of maroon, green, yellow, etc. Easily grown elther in the garden or in pots.

CYCLAMEN. Giganteum. They make fowering bulbs in one season if sown early in sandy soil. Beautifully mottled leares, immense flowers of great substance. Mixed colors .............

FEVERFEW. Clusters of very double, pure white flowers three-quarters of an inch in dlameter. Fine for bedding or pot culture $5 c$ GER.INIUM. Favorite house plant. Seed started early will bloom the first year. Mired colors..5c

HELIOTROPE. In shades of purple, fine for bouquets; the sweet vanilla od or is liked by all

ICE PLANT. (Mesembryanthemum.) Suitable for rock work, hanging baskets, etc. Foliage thick, frosted, wax-like baskets, etc. Follage

IMPATIENS SULTANI. Rosy carmine lowers one inch in diameter, produced freely through. out the season. Although a house plant, it does finely out of doors.......

KENILWORTH IVY. (Linara.) Beautiful tralling plant, with white delicate flowers, for hang-

LANTANA. Shrubby plant with Verbena-like flowers, in shades white, red and yellow...........5c

LOBELIA. A dwarf plant, splendid for porch boxes, hanging baskets and vases. Deep blue flowers and dark follage

PRIMUla. (Chinese Primrose.) One of the finest plants for winter blooming in the house; do well in a cool room and in north window where most other plants fail; very profuse fowering

GENSITIVE PLANT. (Mimosa.) A curious and pretty plant; the leaves close and droop at the elightest touch at night
vINCA. (Periwinkle.) Splendid house and bedding plant, with glossy leaves and circular flower. White, pink, crimson. Mixed..........5c

sMuAx. One of the mostgraceful climbers for the window. Sow seed in February and keep in molst plice.

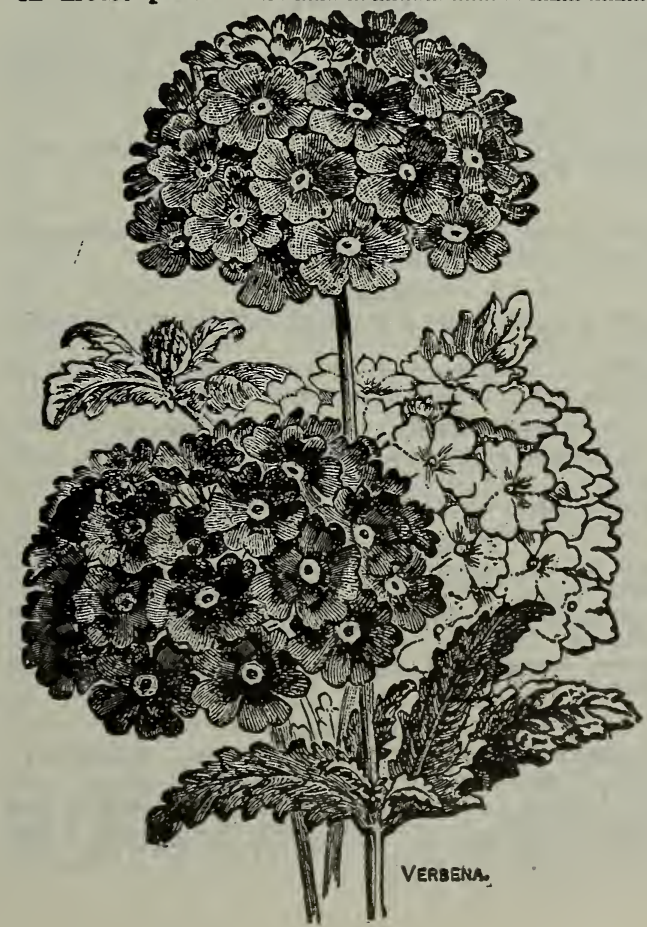




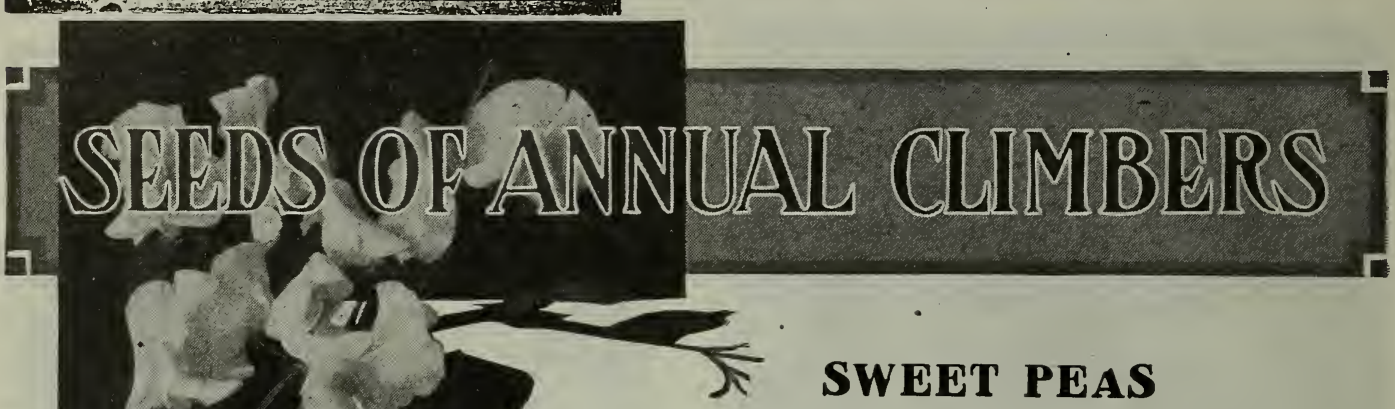

(Very Short Crop)

Sweet Peas are among the most beautiful of all our hardy annuals. Select a sunny, open place, several feet from any building or close fence, and as far as possible from large trees. Sow as early in the spring as the ground can be worked. Make a trench six or eight inches deep, but cover the seed only about an inch at first. As they come up, rake the dirt around the little plants, so that by the time they have reached the top of the ground, the trench will be almost full. Furnish support early. Give them plenty of water, and keep the blossoms picked closely. If they produce seed pods, they will stop blooming.

PRICE OF NAMED COLORS

Except where noted, 5c per pkt., 6 pkt. 25c. 15c per oz., 1 oz. each of any four varieties, $50 \mathrm{c}$; each variety is 10c per $1 / 4$ lb.; $\$ 1.35$ per 1b., postpaid.

\section{ROSE}

Mrs. Dugdale. Light carmine rose with faint markings of primrose.

Phyllis Unwin. Very large size. Rosy carmine. Prince of Wales. Rosy crimson with large hooded flowers.

Prima Donna. Exquisite rose pink; large and profuse. Oz., 15c; $1 / 4 \mathrm{lb}$., 50c; lb., $\$ 1.60$.

\section{BRIGHT RED}

King Edward VII. Grand large flowers of a rich crimson scarlet.

Salopian. Rich red scarlet; large and fine.

\section{ORANGE}

Evelyn Byatt. Standard rich orange salmon wings a somewhat deeper shade. Very striking.

Helen Lewis Spencer. Orange-rose wings with rich, crimson-orange standard. Pkt. 10c; 1/4 1b. $\$ 1.00 ; 1 b, \$ 3.50$.

Miss Wilmott. One of the richest orange-pink sweet peas.

\section{PINK AND WHITE}

Extra Early Blanche Ferry. Standard rose-pink. wings creamy white. Very early.

\section{MAROON}

Black Knight. Deep maroon, veined black; large and open

Othello. Chocolate-red, self-colored.

Shazada. Rich and dark; very attractive.

\section{LAVENDER AND LIGHT BLUE}

Lady Grisel Hamilton. A very light dainty lav. ender.

Frank Dolby. Pale blue, rery large and fine.

\section{PURPLE AND BLUE}

Duke of Westminster. Very rich purple, tinted with violet.

Navy Blue. Dark indigo blue. Large and well formed.

Horace Wright. Large purple flowers on long stems.

\section{WHITE}

Dorothy Eckford. Pure white flowers, beautifully shell-shaped; extra large three on a stem

Nora Unwin. Nicely waved or fluted; usually has three flowers on a stem. One of the best white sweet peas yet introduced. Pkt. 10c; oz., 20c; $1 / 4$ lb. $60 \mathrm{c}$; ih. $\$ 1.85$.
Shasta. Vines vigorous. Standard and wings both waved. Creamy white when first open changing to ivory white.

Burpee's White Spencer. Extra long stems bearing three or four pure white blossoms. Standards fluted. Pkt. 10c; 0z. 30c; 1/4 lb., \$1.00; lb., $\$ 3.50$.

\section{CREAM OR YELLOW}

Hon. Mrs. E. Kenyon. Cream or pale yellow. Large flowers.

Sybil Eckford. Wings delicate lemon; standard blush pink or lemon ground.

\section{DEEP PINK}

Bolton's Pink. The extra large expanded flowers are of a soft salmon-orange pink, very show 7 .

Apple Blossom. Heavily shaded and edged with deep pink, rose and white.

\section{LIGHT PINK}

Countess Spencer. Enormous flowers, delicate pink shading deeped at the edges. Pkt. 10c; $0 z_{\text {. }}$ $25 \mathrm{c}$; $1 / 4$ 1b., 75c; 1b., $\$ 2.50$.

Lovely. A soft shell pink. Very good. Oz., 15c; $1 / 4$ lb., 50c; lb., $\$ 1.60$.

Gladys Unwin. A pale rose pink, with large bold flowers on long stems. Very early. Pkt., 10c: oz., 20c; $1 / 4$ lb., 60c; lb., $\$ 1.85$.

SPECIAL MIXED. A well proportioned mixture of the above named varieties. Light or dark shades as preferred. 15c per oz., 35c per $1 / 4 \mathrm{lb}$; $\$ 1.20$ per lb.; postpaid.

DOUBLE MIXED. Double flowers all colors mixed 5c; oz., 15c; $1 / 4$ lb., $40 \mathrm{c}$.

CHOICE MIXED. A good mixture of many old and new varieties, $5 \mathrm{c}$ per pkt.; 10c per oz.; 30c per $1 / 4$ lb.; 90c per 1b., postpaid.

\section{OTHER CLIMBERS}

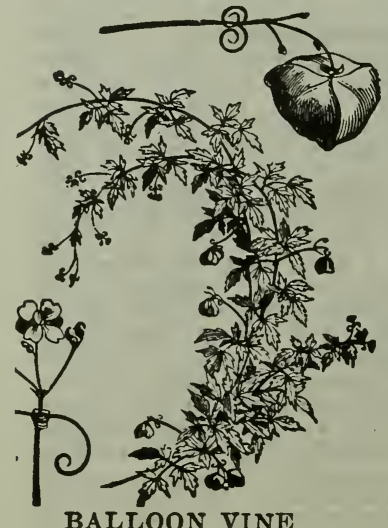

ARIST OLOC H I A. (Dutchman's Pipe.) A n or a metal c li m b e w it h brownish flowers resembling a miniature pipe. A perfectly hardy peren. nial standing any climate where the oak leaves..................5c

BALLOON VINE (Love in a Puff) A rapid growing, graceful c 1 i m ber. Thrives in light coil. Height $5 \mathrm{ft} . . . .5$ 


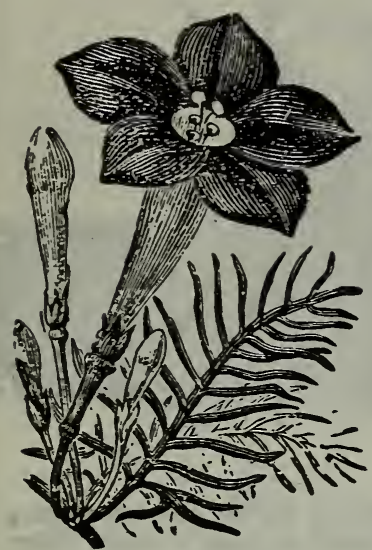

CYPRESS VINE
BALSA II APPLE AND PEAR. Vers rapid a $\mathrm{nd}$ dense c 1 i $\mathrm{m} \mathrm{b}$ e r s, with golden-yellow fruit which opens when ripe, showing the seed and blod-red inside. Mixed......... CYPRESS VINE. A beautiful climber, with a profusion of scarlet or white star-shaped blos. soms and finely cut foliage, adapted to ornamental work. 10 feet. Mixed.........jc

CA N A R Y BI R D FLOWER. A rapid growing, delicate vine with clean, handsome foliage and an abundance of bright canary-yellow blossoms, somewhat resembling a bird with half extended wings. An excellent climber for shady places..5c COBAEA. A beautiful, rapid growing climber, with large purplish, bell-shaped flowers; plant the seeds edgewise, and cover lightly.

DOLICHOS. (Hyacinth Bean.) Splendid climber, producing abundant clusters of pea-like purple and white flowers, followed by ornamental seed pods. 10 to 20 feet

GOURDS. These are desirable for many places where an immense amount of vine is wanted quickly. Most sorts grow 20 or 30 feet in a season.

Dish Rag. Many ladies prefer a dish eloth made of the sponge-like lining of this gourd to anything else, as it is always sweet and clean as long. as any part of it is left...

Sugar Trough. This gourd grows large, holding from 3 to $5 \mathrm{gal}$. Very hard shell.................. Nest Egg. Resembling the eggs of hens; are

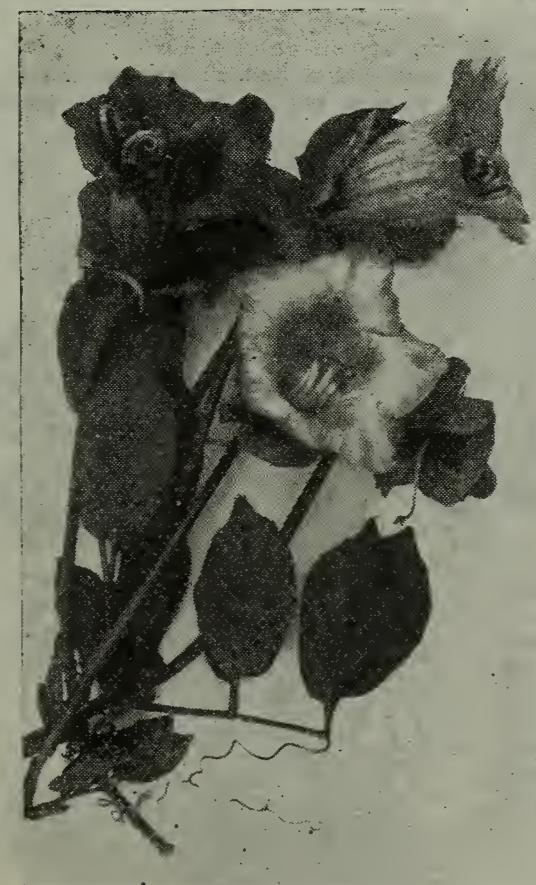

uninjured by cold or wet, therefore make the

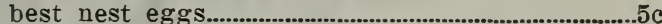
Pear Shaped. Striped yellow and green..............5c Mixed Gourds. All of the above..............................5c

HUMULUS. (Japanese Hop.) A rapid growing climber of easy culture, leares variegated. Sows itself after the first year...............................................5c MOON FLOWER. (Ipomea Noctifiora.) One of the most rigorous climbers. Will grow 30 feet; its large white flowers open erenings and cloudy days. The hard outer coat of the seed should be cut through with a knife, and planted in warm, rich ground. Keep the soil moist.............5c MORNING GLORY OR CONVOLULVUS. The well known kind. Mixed colors..............................5c Japanese Giant. The mammoth flowers of this vine run from 4 to 6 inches across and are marked with most beautiful colors and shading. The vines are strong and robust, growing from 30 to $50 \mathrm{ft}$. high during the season..............5 $\mathrm{c}$

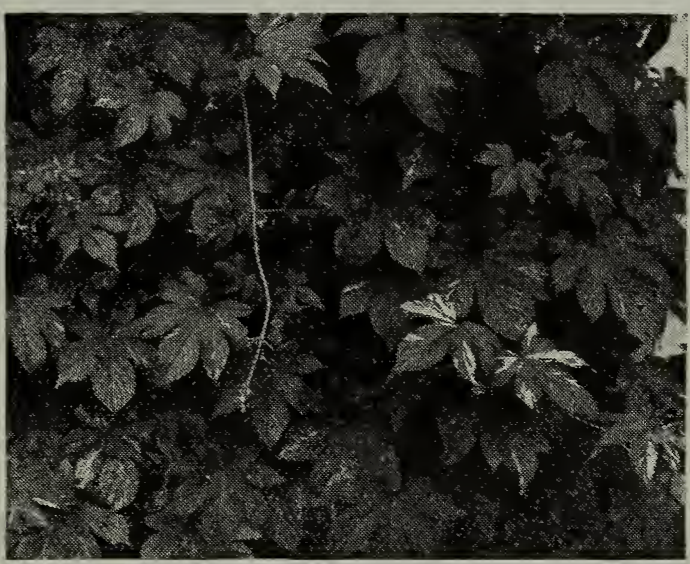

\section{HUMULUS}

NASTURTIUMS. Ideal ramblers that readily climb fences or wire netting. They are also rery showy planted at the top of a steep slope, or simply trailing on the lerel ground. They endure hot, dry, weather very well and bloom continually till frost. Foliage clean and refreshing. These blooms are larger and the stems longer than the Drarf Nasturtiums. Mixed, per oz., 10c.........................................................5c King Theodore. Rich, deep crimson; dark

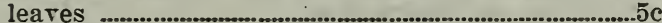
Edward Otto. Brownish lilac.....................................5c Jupiter. Rich golden yellow......................................5c Mme. Gunther's Hybrids. Striped or blotched with shades of red, yellow and orange.................5c Pearl. (Moonlight.) Whitish....................................5c Scarlet. Bright glowing red..........................................5c Vesuvius. Brilliant salmon rose............................5c

PASSION FLOWER. One of the best summer vines for general growing. The beautiful blue flowers somewhat resemble a water lily in shape

WILD CUCUMBER. A very rapid climber. often growing 30 feet in one season. It is cov. ered with clusters of white, sweet scented flowers, followed by ornamental prickly seed pods. It is fine to cover a trellis, old tree or unsightly building, and will sow itself after the first year. Oz., 15c; pkt., 5c.

SPECIAX NO. 16. For those who desire vines to cover long stretches of fence, etc., we have a mixture of 12 or more varieties of annual climbers $15 \mathrm{c}$ per $1 / 2 \mathrm{oz}$; 25c per oz. 


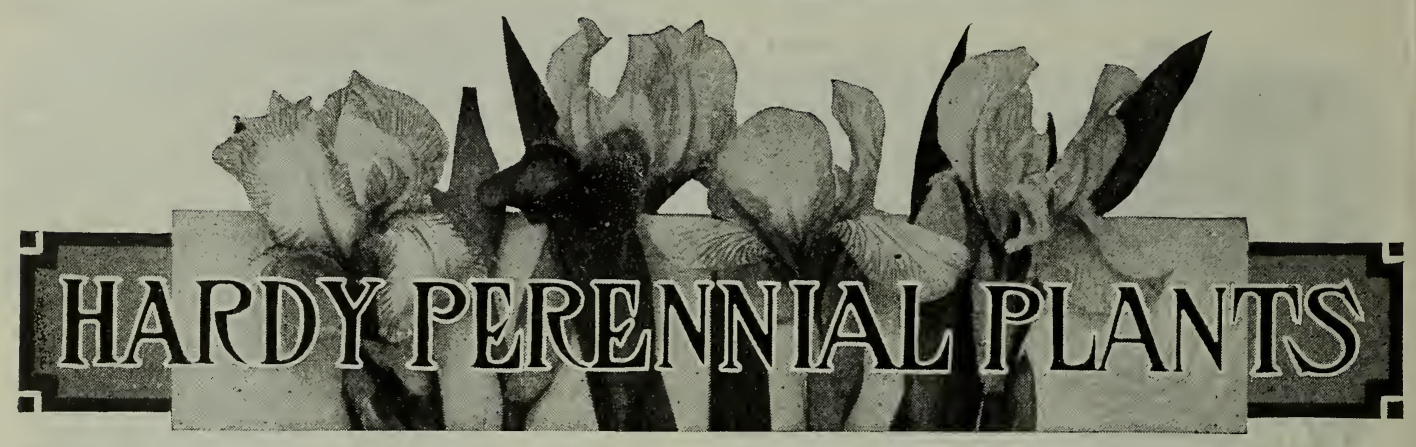

\section{PERENNIALS}

When planted once they are always there. The varieties we list are perfectly hardy, the tops dying cown in winter, but coming up again in the spring, the flowers becoming better as plants grow older.

\section{IRIS}

These flowers have been overlooked. They are perfectly hardy and exceedingly beautiful. As they multiply with great rapidity, one does not have to expend a great sum in order to get a fine bed of them started. Put the Iris in a sunny place where, if possible, they will have some bullding or a bedge to protect them from the wind. The ground should be rich, and well supplied with water. Spade the earth deep and plant the roots 18 inches apart, corering them 2 inches. Keep them well cultivated and you will be well repaid for your trouble.

bibirian BLUE. Probably the inest blue flower on earth. A real deep blue, not at all a purplish shade. The stems are long and as the flowers last a long time in water, they are excellent for cutting. 15c each, 6 for 50c; postpaid.

GIRMAN IRIS. (See heading.). The Iris so commonly seen. Often called Flags. Blooms in great profusion during June and July.
SILVER QUEEN. White with a delicate ble edge.

GYPSY QUEEN. Yellow and brown, very showy. LILAC. Palest blue..

CREAM. A fine cream color.

WHITE. Pure white.

BLUE. The common blue Iris.

15c each, 6 for 50c; postpaid.

\section{HARDY PHLOXES}

These we consider the most desirable of all hardy perennials, flowering abundantly from July untll late in the autumn. The immense flower heads often measure 7 inches across with flowere a large as a half dollar, and comprise all shades-vermillion to white. They delight in sunny location and rich oil, but are by no means particular. Height, 1 to 2 feet.

AICESTE. Deep violet, shading almost to blue.

ATHIS. Deep, clear salmon. Some claim this to be the showiest variety in cultivation.

COQUELICOT. The anest and brightest red of all the Phlox, the color is a bright orange-scarlet.

ESCLAIREUR. Clear, rosy-red, with lighter large center; large florets and a masnincent bedder.

HENRY MURGER. Enormous pure white lowers, with very large, showy,

deep, carmine eje or center: Ine florets and trusses.

zossuth. Rlch deep purple, extra ine.

LA PERLE DU NORD. Pure white; large, deep, dis. tinct red eje; extra ine.

LOTHAIR. Clear, even carmine, deep crimson eje.

MACULATA. Tall branching, producing good sized heads of purplish rose flowers.

MIS LINGARD. Pearly-white flower, with a very faint plnk eye; very remarkable bloomer, produclng two or three crops of flowers during the season. Indispensable as cut flower for florists' use.

NIOBE. The deepest, darkest, richest red with crimson hues.

PANThion. Large, deep, clear, bright pink with faint halo: a charming variety.

PrACHBL OW. Delicate peachblow pink, shading to white, large trusses; elegant.

RICHARD WALLACE. Pure white, with volet-rose eye; large towers in immense panlcles. Too much cannot be sald of this variety.

R. P. STRUThers. In our estimation the very best Phlox grown today-it has no faults. Color clear cherry-red, suffused with salmon shades; deep red eje; lne, large truss. The color is so clear and clean that each individual floret tands out as distinct as a cameo. PRICE

seed of Phlox. Mixed only, per pkt., 5c.

All Plants. Each 15c; 6 for $80 \mathrm{c} ; 12$ for $\$ 1.50$; pontpald.

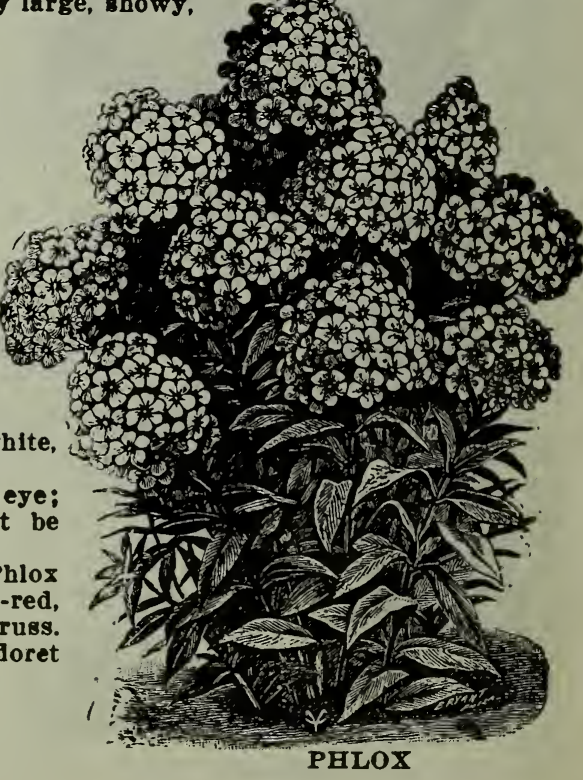




\section{Perennials and Biennials}

In the following list we describe Biennials and Perennials which live in the garden and bloom the following year. While thej do not bloom as quickly as Annuals, unless you buy the plants, they are worth waiting for. They embrace some of our most beautiful flowers, and many continue to give \& to display for years.

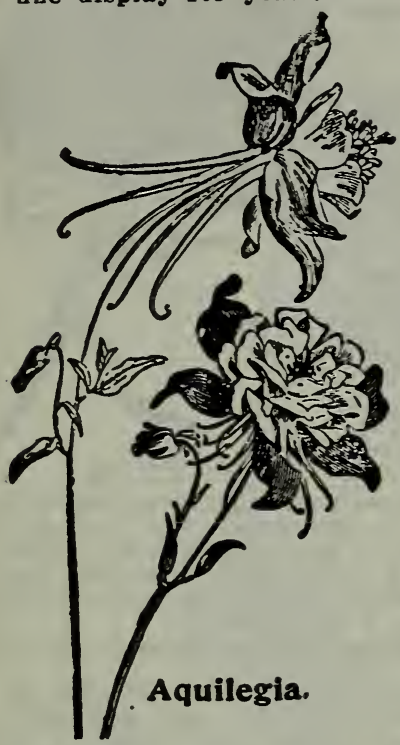

ACHILLEA. (Tho Pearl.) The finest of all plants for cemetery use. The plants grow about 15 to 20 in. high and are completely covered with double pure white flowers from July until frost. o ne plant will produce $h u n d r e d s$ and sometimes $t \mathrm{~h}$ o usands of blossoms the first season. Plants 15c each, 6 for $80 c$; postpaid.

ACONITUM. (Napellus.) Grows in any good garden soil, producing long spikes of curiously white shaped flowers. Fine for shadj corners. Plants $15 \mathrm{c}$ each.

DLUMIA. Monntain Fringe or Allegheny Vine, ) desirable plent worth growing for its delicate, graceful foliage resembling Maiden's Hair Fern. The second year it is a pretty climber with tiny pale pink flowers. Likes a shady location. Biennial..... in any good soll

AsTERS. (Perennial.) Single flowering. Grow well in any good soll.
Mixed colors. Plants

ARTEMESIA. Decorative plant of greyish green color with aromatic

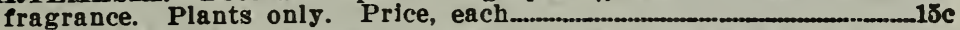

ANFMONES. (Wind Flower.) They resemble in shape huge Marguerite Daisles.

Whirlwind. Double. Snow-white, waxy texture. Prince Henry. Dark red.

Queon Charlotte. Delicate lavender. All Anemone plant $15 \mathrm{c}$ each, 6 for $80 \mathrm{c}$; postpald.

AQUILEGIA. (Columbine.) The Columbine is an old favorite, late spring and early summer blooming plant, growing about 2 feet high, succeeding in any ordinary garden soll. Mixed, seed only.

Canadensis. Red and yellow.

Chrysanthemums. Golden yellow.

All Aquilegia plants $12 \mathrm{c}$ each, 3 for $30 \mathrm{c}$; postpaid

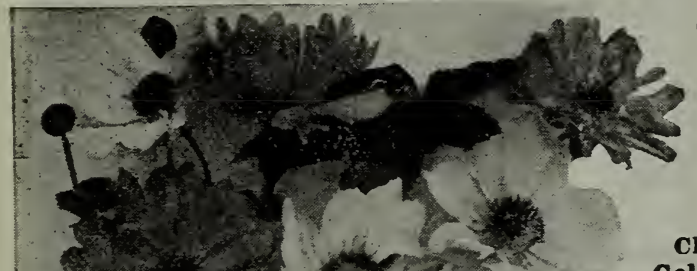

BELLIS. (Double English Daisy.) Very pretty for edgings. Blooms during the spring. Sow early in house, and transplant to a rich, par. tially shaded situation. Seed only. White and

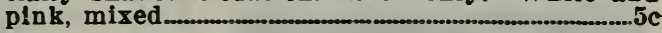

BLEEDING HEART. (Dielytra Spectabllis.) One of the most beautiful of hardy border plants. Flowers in the early spring with rose colored. heart-shaped flowers hanging from the under side of branches their entire length. Perfectly hardy and easily cultivated; grows about 2 feet high. Plants only. 20c each, 3 for 50c; postpald.

CAI YCANTHEMA. (Cup and Saucer.) Resembles the Canterbury Bells, differing onls in having an extra large calyx, making it look like cup and saucer. Plants only. Each............................15c

CAMPandua. (Canterbury Bells.) Popular peren. nials producing bell-shaped flowers of many different colors. Mixed seed 5c. Plants. each........15c CHRYSANTHEMUMS. Very popular for outdoor bedding purposes. They are quite hardy and with but a slight covering of leaves or coarse stable litter during the winter will take care of themselves after once planted, and produce an abundant profusion of bloom. Mixed seed......................................5c

Climax. Deep rosy-pink.

Goldfinch. Magnifleent; gold, shaded crimson.

Goldfleece. Large, bright, lemon yellow.

Kadar. Clear, bright red.

Prince of Wales. Magnificent; pure white.

Plants 15c each, 6 for $80 \mathrm{c}, 12$ for $\$ 1.50$ : postpaid.

COREOPSIS. (Lanceolata.) Giant flowering golden-yellow daisy-like flowers borne in the greatest profusion; invalualue for cuttings. Seed 5c. Plants $12 \mathrm{c}$ eack, 3 for $30 \mathrm{c}$ : postpaid.

DELPHINIUM. (Perennial Larkspur.) The best perennial knowu. The brilliant flower spikes are in erery shade of blne. Blooms in June. continuing a long time if the flowers are cut before they fade. Hybridum. Mixed seed $5 c$.

Formorum. Plants $15 \mathrm{c}$ each, 6 for $80 \mathrm{c}$; postpaid.

FEVERFEW. (Pyrethrum.) These are among the most charming of our hardy plants. Of the easiest culture. Flowers are aster-like in form. of the most beautiful coloring. Blooming throughout the summer. Seed bc. Plants 15c each, 6 for $80 \mathrm{c}$; postpaid.

FORGET-ME-NOT. (Myosotis.) It flourishes best in a moist, shady situation. Bright blue. Seed only, 5c.

GAILLARDIA. (Grandifiora.) The perennial blanket flower. Perfectly hardy and requires little care. Seed 5c. Plants $15 \mathrm{c}$ each.

GYPSOPHILA. (Paniculta.) (Baby' Breath.) Produces numerous panicles of amall white flowers; ine for bouquets. Seed only, sc. 


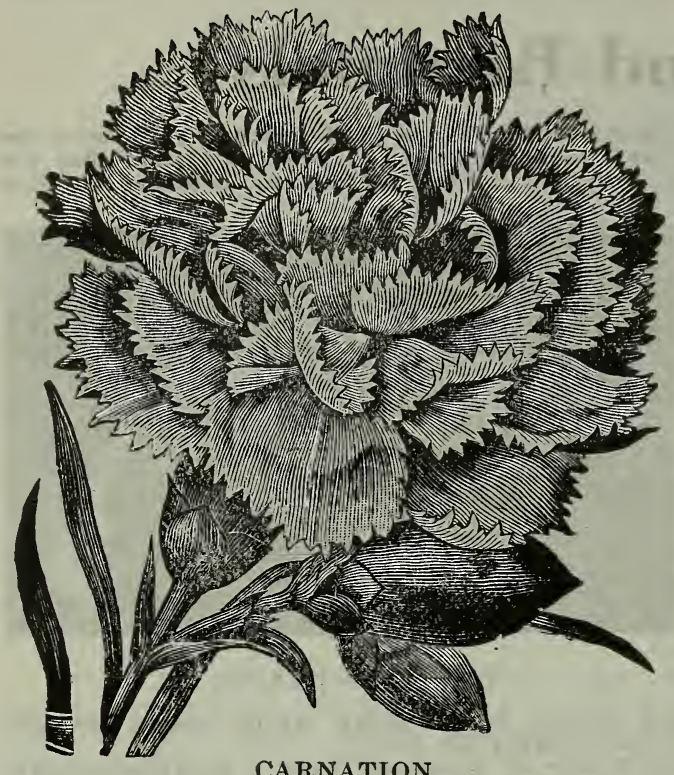

CARNATION

CARNATIONs. Popular favorites, which are deliciously fragrant; colors extremely rich and beautiful, if protected will live out over winter. Extra Choice Mixed. Seeds only

Margaret. Dwarf habit, blooms in a few months from seed. Choice mixed seeds.

Red Grenadin. For yielding a quantity of double red flowers there is no outdoor carnation that can equal it.............................................................5c White Grenadin. of good form and substance. Like the above except color. Seed 5c. Plants

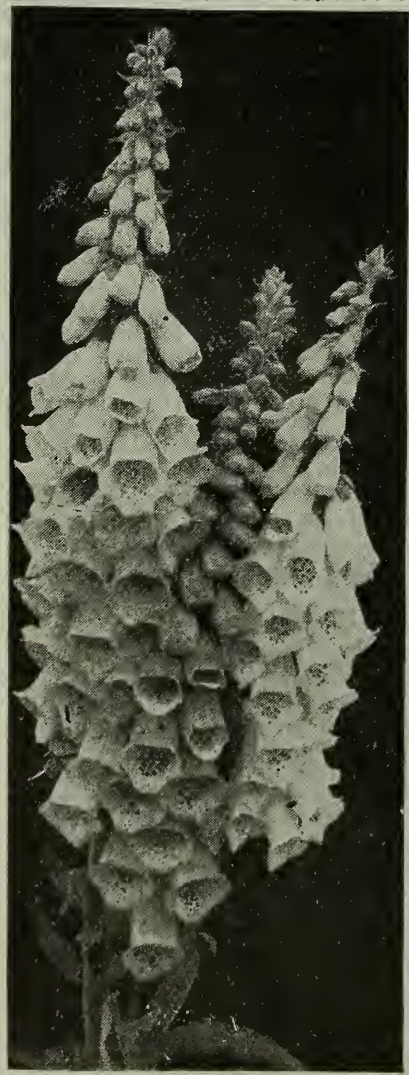

FOX GLOVE OR DIGATALIS of all carnations each ….............15c

DAISY, G I A N T SIIASTA. (See on Cover.) A hardy perennial blooming for several months, and more abundantly each season. The flowers are extre mely large and graceful, center is yel$10 \mathrm{w}$, a $\mathrm{nd}$ the petals are pure white The cut flowers placed in water will keep for a week. Seed 10c. Plants 15c each, 6 for $80 c$; postpaid.

DIGITALIS. (Fox Glove.) (See on Cover.) An oldfashioned plant that furnishes a grand display of th i m b le-shaped flowers in immense s $\mathrm{pikes}$ during July and August.

Gloxin iaeflora. (Alba.) White, very fine, also purple, rose and mixed.

Mixed seed $5 c$

Plants in named colors 15c each, 6 for $80 \mathrm{c}$; postpaid.
DIANTHUS. Perennial, blooms first summer. Chinensis. (Double Chinese or Indian Pinks.) "C o m p a c t plants w it $h$ large clusters of $\mathrm{double}$ flowers

Heddewigi. (Double Japan Pinks.) Much in ther ese pinks.....................

Heddewigi Fireball. Brilliant scarlet.......... Heddewigi Snowball. Pure white.................

Heddewigi Mixed. All colors

Heddewigi Midnight. Blood red... 5 Plants of Fireball. Snowball, Pink and Midnight, each........15c Plumarius. Cove pink sweet scented ; flowers double fringed. Seed only....................5c

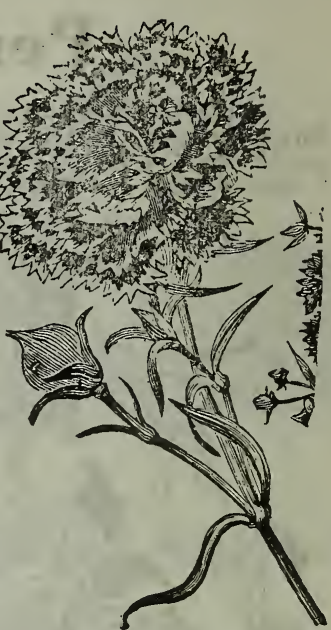

DIANTHUS
HIBISCUS. (Crimson Eye.) Tall, free flowering, hardy plants with remarkable large and showy flowers. Thrives in most loamy soils, producing throughout a long period numerous mammoth flowers, sometimes 6 to 8 inches across. Plants grow 3 to 5 feet tall.

Golden Bowl or Giant Yellow. Deep cream with a velvet maroon center.

Moscheutos. Flowers light rosy red with dark centers. Plants $15 \mathrm{c}$ each, 6 for $80 \mathrm{c}$; postpaid.

HOLLYHOCK. For planting in masses by itself or as a background for lower growing plants, the hollyhock cannot be dispensed with. The double variety which is coming into general use is much superior to the old-fashioned sorts. We offer double varieties only. Plants white, yellow, red, pink and crimson. $15 \mathrm{c}$ ea., 6 for $80 \mathrm{c}$; postpd. Charter's Superb. Double mixed............................5c Allegheny. Edges of petals finely fringed. They are large sized, fairly double, with soft, rich colorings. Seed..............................................................5c

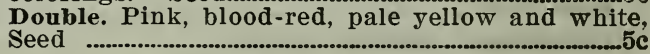

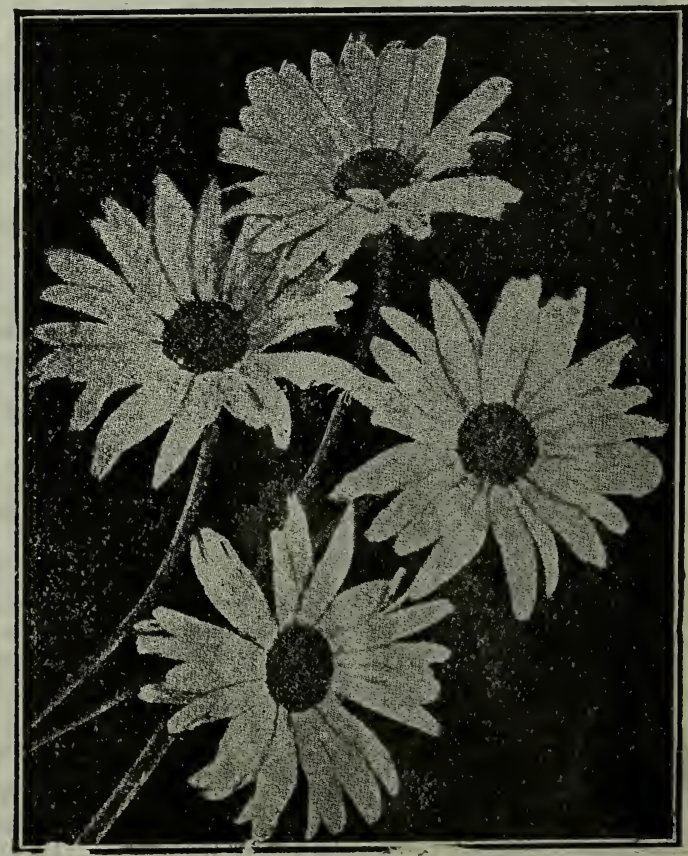

DAISY, GIAN'I' SHASTA 


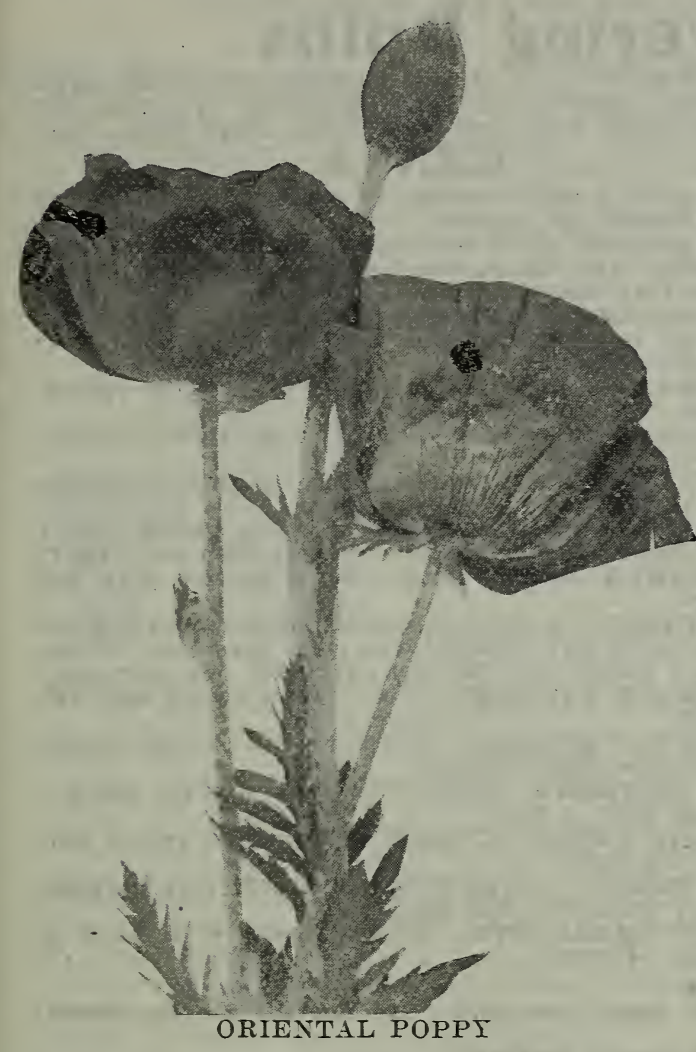

LATHYRUS. (Perennial Peas.) Free flowering plants, growing fire to ten feet high if giren support. Will not bear transplanting. White and lilac, mixed. seed only

LYCHXIS. (Burning Star.) Chalcedonica. Showy and free flowering hardy perennials of easy culture. Verbena-like heads of bright scarlet flowers. seed $5 c$ Plants $15 \mathrm{c}$ each.

MINT. Old-fashioned mint. Clumps $10 \mathrm{c}$ each, 3 for 25 c; postpaid.

PENSTEMON. Flowers bell-shaped, an inch and a half long. borne in racemes or spikes. The roots should hare some protection in winter. Seed only :c PIXKs. See Carnation, Page 48; Dianthus, Page 48.

PLATICONDON. Splendid variety, producing very showy flowers during the whole season. Form large clumps. Are excellent for planting for permanent borders. Color blue. Plants 15c each.

POPPY. (Oriental.) Large, gorgeous. scarlet blossoms; bottom of petals black; one of the showiest of hardy perennials, producing flowers 6 inches and orer in diameter vers earlr. Seed 5c, plants $12 \mathrm{c} \mathrm{each}$

RIBBON GRASS. Deep green foliage, broadly striped lengthwise of the leaf. Pure white. rery handsome. Plants only, 1oc each, 6 for S0c; postpaid.

RCDBECKIA. (Golden Glow.) A hardy perennial plant. growing \& feet high, branching freely and bearing on large graceful stems hundreds of exquisite double blossoms of the brightest golden color, and as large as Cactus Dahlias. Plants only, 10c each, 3 for 25 c; postpaid.

S T O K E I I C : ANEA. (Cornflower Aster.) At hardy perennial. bearing handsome larender blue cornflower-like blossoms. Height 2 f e e t. Plants $15 \mathrm{c}$ each. Seed .....................10c

SWEET ROCKET, (Hesperis.) Sometimes called Dame's Violet Produces clusters of pink and white four-petaled flowers which are very fragrant during the erening. It grows readily in the open ground. $1 \frac{1}{2}$ feet high. Seeds only

SWEET WILLIAM. (Dianthus Barbatus.) The plants when in flower are 18 inches in height and produce large clusters of brilliantly colored flowers on stont. stiff stems. Sow seed in drills early in spring. Then well started. thin out, or transplant.

single. Mixed

Double. Mixed.

Bright Red. Single...

Pure White. Single

Double Mixed Plants

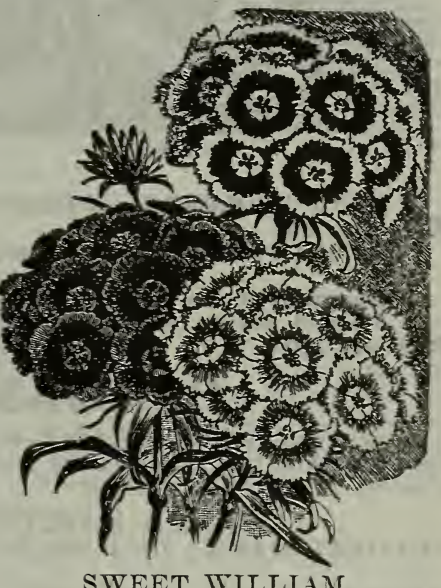

each 15

SWEET WILLIAM

\section{PEONIES}

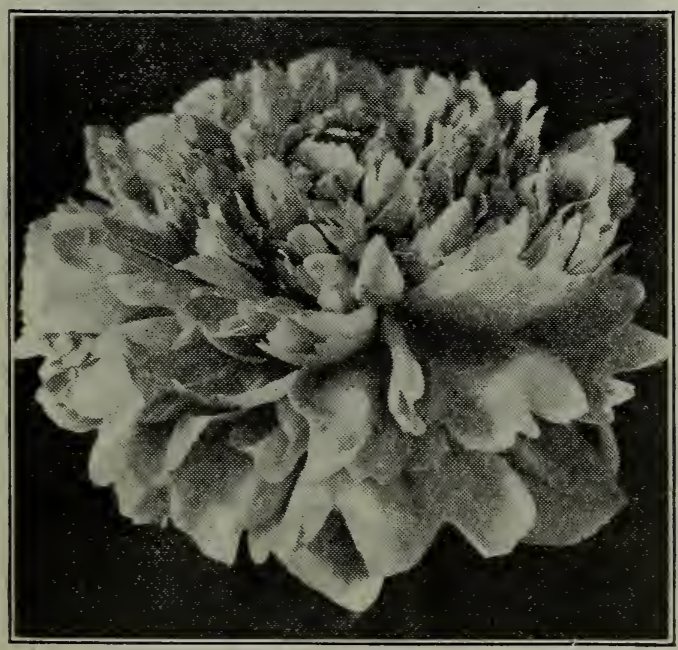

Perfectly hardy. large, bush-like plants with great flowers rivaling the rose in color and perfection of bloom; pleasantly fragrant. In bloom for Decoration Day.

ANDRE LAURIES. Light red, prolific and beautiful. Each, postpaid, 30r

LA SUBLIME. A rerJ striking flower of a deep rich crimson color. A sure bloomer. $40 \mathrm{c}$ each: postpaid.

L'ESPERENCE. Very early, a great farorite, rosy pink. free flowering. $30 \mathrm{c}$ each; postpaid.

QUEEX VICTORIA. Early, choice standard $w$ hite. 30 c each; postpaid.

GRANDIFLORA ROSEA. Verr fine, fragrant rose pink. One of the hardiest and independent to late hard frosts. $30 \mathrm{c}$ each; postpaid.

HUMEI. Immense late cinnamon scented flower of rarnished pink. $30 \mathrm{c}$ each; postpaid.

Blaine Co., Nebr., Apr. 26, 1912.

I receired the roses all 0 . K. and thank you erer so much for them. We think they are all 0 . K. and will grow nicely. FRED SCHIPPOREIT. 


\section{Summer Flowering Bulbs}

Plant in deep, rich soll, when the ground becomes warm. For earliest flowering the tender bulbs may be started in the house. For succession of bloom, plant up to June 1st. After fall frost, lift the bulbs, let them dry, and then removing the tops, store in a cool, dry place, away from frost, for planting in the spring.

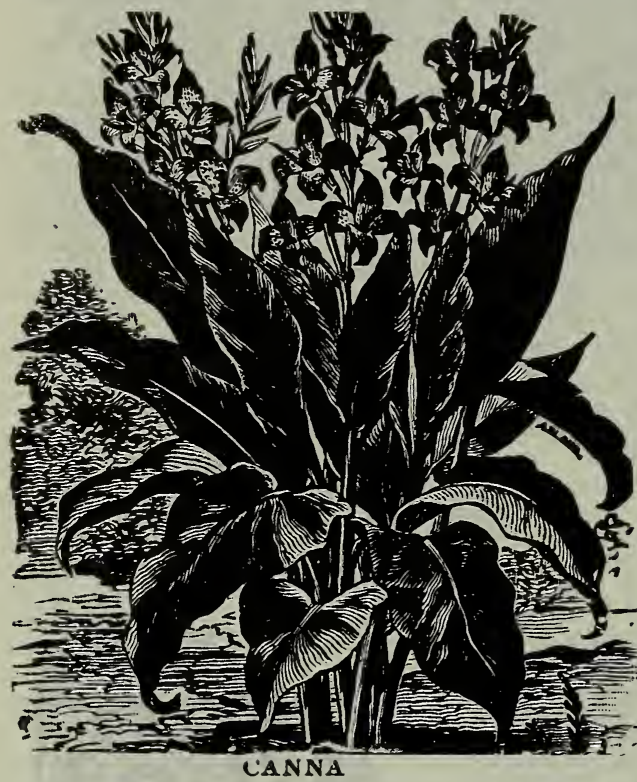

CANNA

The most popular decorative plant of the day. The earth should be spaded deeply and well enriched. After planting water sparingly until the plants have taken root and show good leaf growth. When in full foliage they may be watered very freely.

We are making a specialty of Cannas and you will find our plants extra fine and the bloom of very beautiful colorings.

ALLEMANIA. Scarlet orange bordered with yellow; 6 feet.

ALPHONSE BOUVIER. Richest red; showy variety. 5 feet.

BEAUTE POINTEVINE. A rich glowing crimson. $21 / 2$ feet.

BURBANK. Immense flowers of a rich yellow. 31/ $\mathrm{ft}$. EGENDALE. Bronze foliage, flowers deep red. $4 \frac{1}{\mathrm{ft}} \mathrm{ft}$ ELIZABETH HOSS. Large yellow spotted with red. 5 feet.

EVOLUTION. Bronze foliage with flowers cream white, shading of light salmon, the most rare kind. 4 feot. Started plants only 25c each; $\$ 2.50$ per doz; postpald.

FLORENCE VAUghaN. Pure yellow dotted with rel. 5 feet.

FREDERIC BENARY. Currant with orange throst and yellow edge. 5 feet.

IING HUMBERT. Giant flowered; orange scarlet; bronze leaf. 4 feet.

MADAME CROZY. Crimson scarlet with yellow border. 3\%/2 feet.

MME. BGRAT. Large flower of a soft ross carmine, nearly pink, six feet high.

QUEEN CHARLOTTE. Rich crimson with band of yellow. 4 feet.

\section{Price}

KING HUMBert. Dormant Roots $8 \mathrm{c}$ each, 75c dozen; postpaid. By express 65c per dozen; \$.00 per 100 .

EVOLUTion. Started Plants only $25 \mathrm{c}$ each, $\$ 2.50$ dozen; postpaid.

All Other Cannas

Dormant Roots $8 \mathrm{c}$ each, 75c per dozen; postpaid. By express, 65c per dozen; $\$ 5.00$ per 100.

Started plants ready May 10th, $10 \mathrm{c}$ each, $\$ 1.00$ per dozen; postpaid. By express, $85 \mathrm{c}$ per dozen; $\$ 6.50$ per 100 .

\section{DAHLAS}

Large, symmetrical double flowers, having oruad velvet petals, incurving at the center. Bloom from August to freezing weather.

\section{CACTUS VARIETIES}

COLONEL OAKS. Dark maroon shading to violet.

NEDRA. A soft, maure pink; a unique color in the Dahlia family and one hard to describe. SPOTLESS QUEEN. Purest white, an excellent variety for cutting purposes.

STANDARD BEARER. Rich fiery scarlet, one of the very best.

sNOW. A beantiful pure white.

\section{DECORATIVE VARIETIES}

AMERGERONE. A very large flower, deep plum purple.

EUGENT TEELE. A very fine deep scarlet, produced on long stems, valuable for cutting.

FLORA. Very large, pure white; early and profuse bloomer with long stems.

JACK ROSE. In color it resembles the Jacqueminot rose. Profuse bloomer and splendid for cutting purposes.

MAID OF KENT. A very striking variety. Rich cherry red, tipped white.

MRS. HARTONG. Color light fawn suffused with pink.

sYLVIA. A beautiful deep pink shading lighter to the center.

SHOW VARIETIES (See Cut)

A. D. LIVONI. Rich pink, finely formed; a very handsome flower.

ARABELLA. Very large and beautiful. Color soft primrose shaded with rose.

GLENCO. Ball-1ike in form, of bright scarlet. Especially good for cutting.

(Balance of Dahlias and Prices on next page)

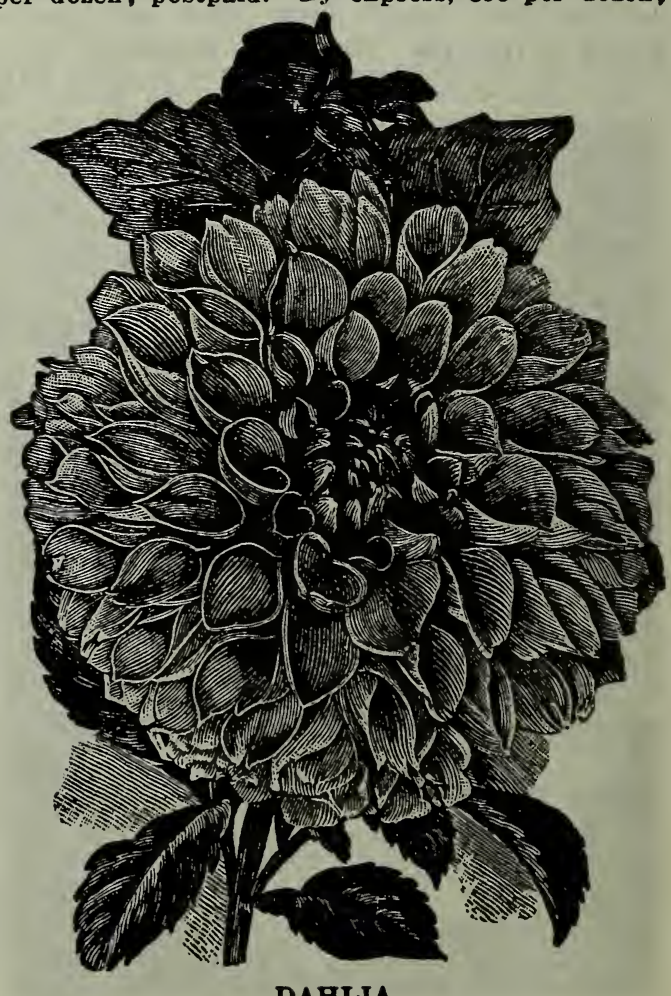

DAHLIA 


\section{SUMMER FLOWERING BULBS-Continued}

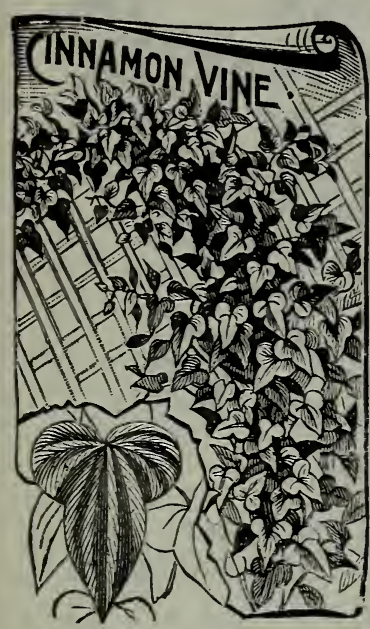

\section{DAHLIAS-Continued}

LUCY FAWCETT. Sulphur yellow streaked and flecked with crimson, ane. MISS DODD. Large, pure canary yellow.

PURPLE GEM. Rich royal purple, clear and constant. This variety is a decided improvement over the old varieties.

QUEEN VICTORIA. Large, rich golden yellow. RED HUSSAR. Richest cardinal red, with long stems. Splendid for cutting.

VARNUM'S VARIGATED. Bright red, tipped with white.

\section{PRICE ALL DAHLIAS}

Any of the above named Dahlias $20 \mathrm{ceach}$ : $\$ 2.00$ per dozen; postpaid, $15 \mathrm{c}$ each, $\$ 1.65$ dozen by express.

Mixed Dahlias. Including some of the above varieties $15 \mathrm{c}$ each; $\$ 1.50$ per dozen.

Dahlia Seed. Single, 5c pkt.; double, 5c pkr.

CALADIUM ESCULENTUM. (Elephant's Far.)

Fine tropical plant bearing immense leares.

Start as directed for cannas, when growing you cannot make the soll too rich or keep it too wet. 15c each; 2 for $25 \mathrm{c}$; postpaid.

CINNAMON VINE. A vine of rery rapid growth, quickly covering trellis with a handsome, crean, ylossy green foliage. Plant the bulbs about 1 inch deep in rich soll. With the approach of winter cover with straw and leaves

to prevent freezing. 3 bulbs for $15 \mathrm{c} ; 6$ for $25 \mathrm{c}$; postpaid.
KODZU Vire. (Jack-and-the-Bean-Stall.) A most remarkable hardy climber. Starts slow, but in a few weeks grows almost beyond belief. Foliage dark green. Fine for porches and arbors. Roots, small, 13c each; 3 for $40 \mathrm{c}$; postpaid. Large roots, $25 \mathrm{c}$ each, by express.

YADERIA VINE. A rapid climber, twining to great heights. Thick, glossy leaves and featherJ, very fragrant white flowers. It grows anywhere, but does better in a warm, sunny location. It is also very pretty for training in the house. Strong tubers, 5c each; 3 for $10 \mathrm{c} ; 30 \mathrm{c}$ per doz.; postpaid.

MATRIMONY VINE. Well known, hardy, fast growing vine; handsome when covered with scarlet fruit in Autumn. Plants, 35c each; postpald.

OxAlIs. Summer-blooming. A very pretty plant for edging bower beds. Bears an abundance of pink and white flowers and delicate follage. 15c per dozen; postpaid.

TUBEROsE. A beautiful, white, wax-like, very sweet-scented, double nower, growing on tall stems. 5c each; 40c per dozen; postpaid.

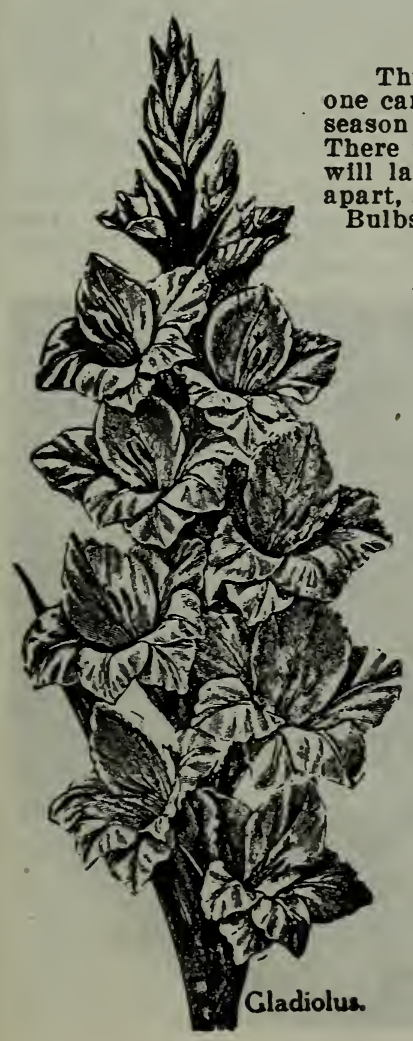

\section{GLADIOLIUS}

This is one of the best of the summer-flowering bulbs. It is a flower anjne can grow and is lovely enough to satisfy the most exacting. The flowering season may be continued by planting from middle of April to the first of June. There is no limit to the range of color. Nothing is finer for rases; the flower. ill last for days and the buds open after being cut. Set the bulbs 6 inches part, and 2 to 4 inches deep. For fall treatment, see under "Summer Flowering Bulbs," page 50.

BRENCHLEYENSIS. Intense scarlet; fine. 3c each; 25c dozen.

AUGUSTA. Lovely, gure white, blue anthers. 5c each; 50c dozen.

"1900." Brilliant red, white blotch. 4c each; 35c dozen.

YELLOW SHADES. 5c each; 50c dozen.

MADAME MONNERET. A beautiful pink. 3c each; 25c dozen.

MAY. White, flanked crimson, superb spike. 3c each; 25c dozen.

GOFF'S HYBRIDS. The size and beautiful shadings of this strain give the greatest possible range of varieties. $5 \mathrm{c}$ each, 6 for $25 \mathrm{c} ; 40 \mathrm{c}$ dozen; postpaid.

CHILDSI, FINE MIXED. All colors and varieties. Every one a beauty. 5c each; 40c doren; postpaid.

GOOD MIXED. Especially recommended to make a good brilliant show in the garden for a small outlay. All bloomers. 3c each, 4 for $10 \mathrm{c}$, $25 \mathrm{c}$ dozen; postpaid. 50 for $75 \mathrm{c}, 100$ for $\$ 1.00$, by express at buyer. expense.

\section{FALL BULBS}

In September of each year, we Import from Holland, a large shipment of Fall Bulbs. These should be planted any time from the middle of September until the ground freezes. This list includes Tulips, Hyacinths, Narclssus, Crocus, Jonquils, Sclllas, Chionodoxas, for outdoor planting. Roman Hyacinths, Freeslas, Chinese Sacred Lillies, Easter Lilies, Callas and Oxalis, for planting in the house.

We issue our Fall catalog about the middle of Angust. If jou do not receive a copy by the flrst of September, let us know. 


\section{HARDY LILIES}

Lilies thrive best in a dry, rich soil, where water will not stand in the winter. After planting they require very little care, anc should not be disturbed for years, as established plants bloom more freely than if taken up annually. In this list we offer only such varieties as are hardy enough to stand the winter out of doors. It is well, however, to protect them with a covering of litter or straw.

LILY OF THE VALLEY. Bearing slender stems set with tiny white bells, delightfully fragrant; do well in shady situations. Flower each season without any attention. 6c each; 3 for $15 \mathrm{c}$; 40c per dozen; postpaid.

AURATUM. (Gold-banded.) Immense white flowers, thickly spotted with crimson, each petal having a distinct yellow stripe; very fragrant. Blooms in July. 15c each; 3 for $40 \mathrm{c}$; postpaid.

ELEGANS. Perfectly hardy and will succeed in almost any situation. Flowers large and showy; bright red, flushed orange. 11/2
feet. Blooms in June and July. 12c each; $\$ 1.25$ per dozen; postpaid.

FUNKIA ALBA. (White Day Lily.) A handsome, showy plant with beautiful broad ovate leaves. The large, lily-like, pure white, fragrant flowers are borne in large trusses during August. $20 \mathrm{c}$ each; 3 for $50 \mathrm{c}$; postpaid.

HEMEROCALLIS FLAVA. (Lemon Lily.) Flower large, pure yellow: quite fragrant. Grows $21 / 2$ to 3 feet high. Blooms in July and August. $15 \mathrm{c}$ each; 3 for $40 \mathrm{c}$; postpaid.

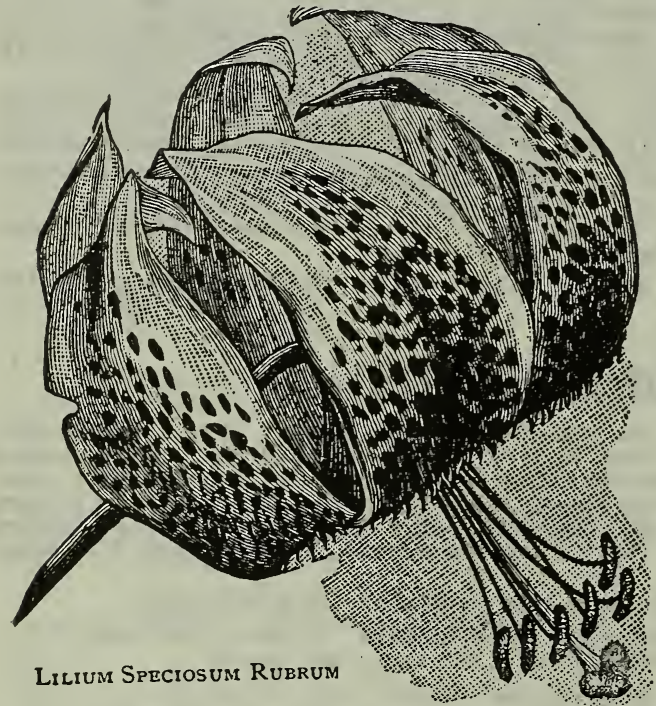

\section{STANDARD FLOWER POTS AND SAUCERS}

We pack these carefully, but will not be reponsible for breakage in transit by express.

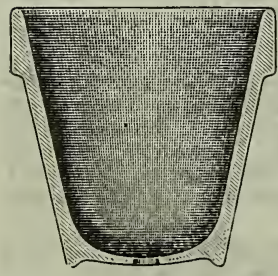

$S$ in.
POTS

Each Doz. 100 2 in. $\$ 0.02 \$ 0.12 \$ 0.80$ 3 in. $.03 \quad .20 \quad 1.25$ 4 in. $.04 \quad .35 \quad 1.85$ 5 in. $.05 \quad .50 \quad 3.65$ 6 in. $\quad .06 \quad .65 \quad 4.50$

$\begin{array}{lll}7 \text { in. } \quad .10 & 1.10\end{array}$

8 in. $\quad .15 \quad 1.50$

\section{SAUCERS}

Each Doz. 100 4 in. $\$ 0.03 \$ 0.25 \$ 1.50$

5 in. $\quad .04 \quad .35 \quad 2.00$ $\begin{array}{llll}6 & \text { in. } \quad .05 & .45 & 2.75 \\ 7 & .06 & .60 & 1.00\end{array}$ $\begin{array}{llll}7 & \text { in. } \quad .06 \quad .60 \quad 4 .(10\end{array}$ $.90 \quad 6.00$

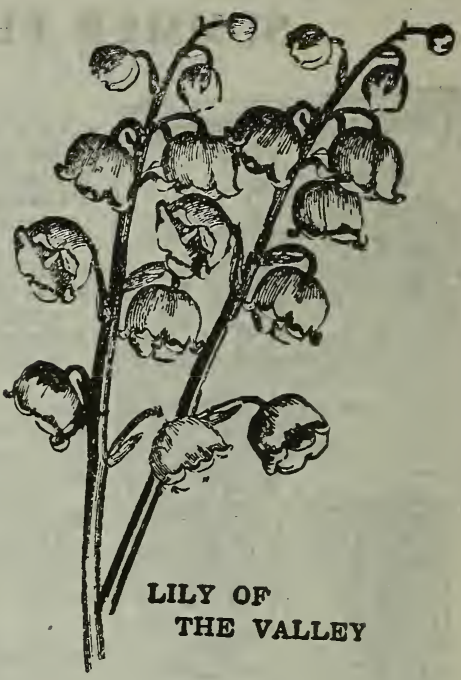

SPECIOSUM RUBRUM. White, beautifully spotted with red; petals reflexed like the Tiger Lily. Very fragrant; flowers in August. This is one of the most useful lilies, perfectly hardy and flowering well under all circumstances. $20 \mathrm{c}$ each; 3 for 50c; postpaid.

SPECIOSUM ALBUM. Same as the above, but pure white. $20 \mathrm{c}$ each; 3 for $50 \mathrm{c}$; postpaid.

SUPERBUM. Flowers bright orange red. thickly spotted with purple. Remarkable for immense height (often 8 feet) and profusion of bloom; a strong plant, bearing from 20 to 30 flowers. Blooms in July. 12c each; $\$ 1.25$ per dozen; postpaid.

TIGRINUM SPLENDENS. The well-known "Tiger Lily," grows from 7 to 9 feet high and bears an immense number of bright orange flowers spotted with black. Blooms in August. Single or double, $10 \mathrm{c}$ each; $\$ 1.00$ per dozen; postpaid.

WALICEI, Flower rich, clear buff, spotted black, late bloomer. 10c each; $\$ 1.00$ per dozen; postpaid.

UMBELLATUM. A splendid hardy Lily, and should be found in every garden. Colors range from deepest red to yellow. Blooms in June. $15 \mathrm{c}$ each; $\$ 1.50$ per dozen; postpaid.

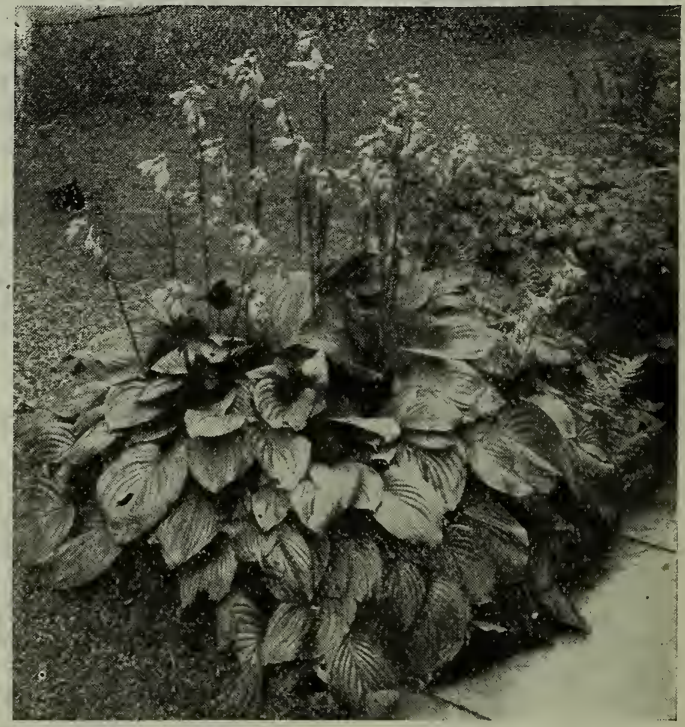

FUNKIA 


\section{BEDDING AND HOUSE PLANTS}

CAN BE SUPPLIED UP TO ABOUT JUNE 1ST

The size of plants furnished by us are, in all instances. as large as can be adrantageouslr forwarded by mail. and are strong, thrifty, well established stock.

\section{ACHYRANTHUS}

LINDENNI. Long lance-shaped leares of a deep blood red. 10c each; 3 for 25c; postpaid.

\section{CARNATION}

ENCHANTRESS. Large, shell pink. 12c each. HARLOWARDEN. Large, free blooming, crimson. $12 \mathrm{c}$ each.

The Premier Quartette of Carnations. All Foul for $50 \mathrm{c}$; or $15 \mathrm{c}$ each; postpaid.

BEACON. Best red.

INCHANTRESS. Best pink.

JAS. WHITCOMB RILEY. Best vellow.

WHITE ENCHANTRESS. Best white.

\section{COLEUS}

FIREBRAND. Maroon shaded with red. GOLDEN BEDDER. Rich golden yellow.

QUEEN OF THE WEST. Large leaf covered with spots of bright carmine and deep maroon and margin of bright yellow.

VERSCHAFFELTII. Rich red; fine bedder All 12c each; 4 for $40 \mathrm{c}$; postpaid.

\section{FERNS}

ASPARAgUS PLUMosus. The fine-leaved rariety used so much in cut flower work. 12c each; 3 for $30 \mathrm{c}$; postpaid.

ASPARAGUS SPRINGERI. Drooping variety, very nice for hanging baskets. 12c each; 3 for $30 \mathrm{c}$; postpaid.

Boston. The well known variety so often seen. $12 \mathrm{c}$ each; 3 for $30 \mathrm{c}$; postpaid.

HARDY FERNS. Live outdoors all winter. 20c each; $\$ 2.00$ per dozen; postpaid.

\section{MISCELLANEOUS BEDDING PLANTS}

ASTERS. One of the most popular of all the gardeu flowers for late summer and fall display. Irixed colors. 50c per dozen; postpaid.

ORIENTAL POPPIES. Large, gorgeous, scarlet blossoms; bottom of petals black; one of the showiest of hardy perennials, producing flowers six inches and over in diameter very early. 10c each; $\$ 1.00$ per dozen; postpaid.

PANSIES. (Griswold's Mammoth Special.) Flowers are rery large. The colors are rich red, chocolate and purple shades, mottled and spotted. 50c per dozen; postpaid.

PETUNIAs. Petunias are very popular for their rich coloring. continuation of bloom, pleasing fragrance and easy culture. Mixed colors. 50c per dozen.

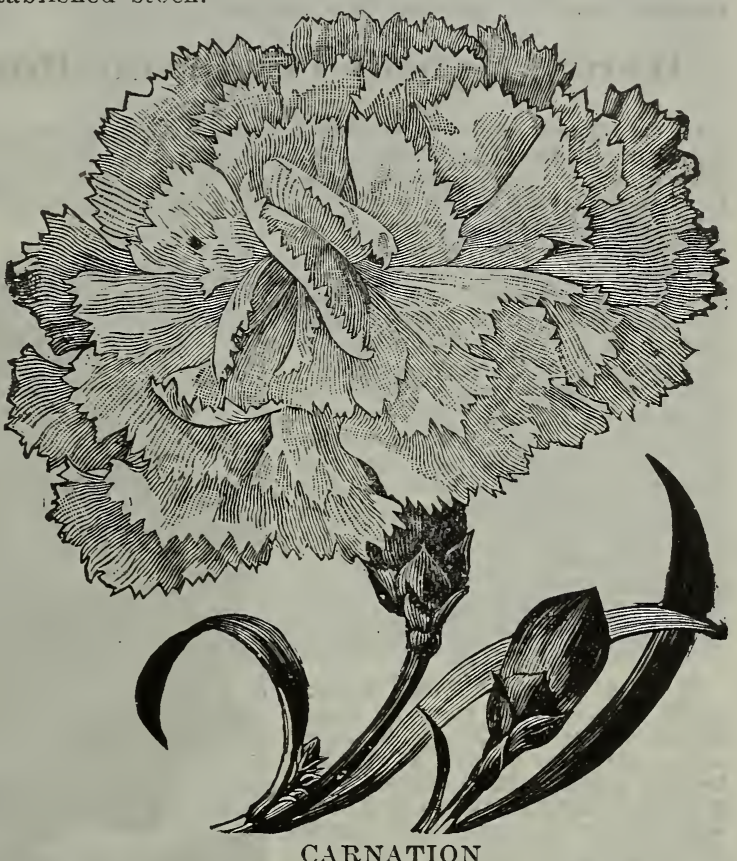

CARNATION

SALVIA. Among the most brilliantlr colored of garden flowers and extremely useful for bedding. Blooms are borne in long spikes, fieryred and continues in bloom until serere frosts. 00c per dozen; postpaid.

VERBENAS. For beds or massing the rerbena is unrivalled. flowers the most brilliant colors. Mixed. 50c per dozen; postpaid.

ZINNIA. Flowers all summer, making the most brilliant display possible, excellent for border or summer hedge. Mixed colors. כ0 $\mathrm{c}$ per dozen; postpaid.

\section{GERANIUMS}

BEACTE POINTEVINE. Bright, double, salmon pink.

BERTHA DE PRESHL. Beautiful silvers-rose

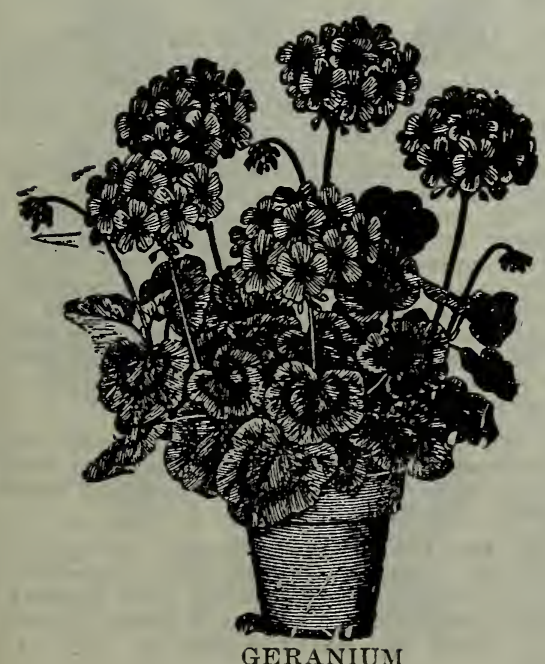

GERANIUM
Contrast. Double. dark, red. free bloomer, dwarf. GENERAL GRANT. Double scarlet, vigorous grower. free bloomer.

GILLIFLOWER. Best single scarlet.

JEAN VIAUD. Bright. rosy-pink, white blotch in center. LA FAVORITE. Double, pure white. the best white. MRS. E. G. HiLL. Single, large, salmon-pink. S. A. NUTT. Double. dark crimson, free bloomer. SUPERB. A beautifui. immense, double scarlet. Strong grower and free bloomer.

\section{IVY GERANIUMS Double Pink}

\section{ROSE GERANIUMS}

ROSE MONSTROSA. The well-known sceated rose-geranium. rose-geranium.

SKELETON. Finely serrated leaf, scented. BORDER GERANIUMS

MLLE SALIEROI. A dwarf, compact. growing geranium. With small white and green leaves; fine for bordering:

Price of all geraniums $12 \mathrm{c}$ each; $\$ 1.20$ per dozen; postpaid.

RUBBER SPRINKLER

With bent neck....................................................\$0.75

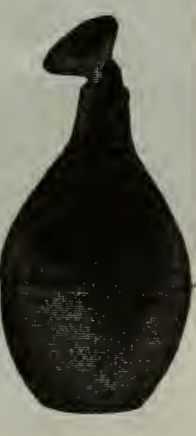


NOTE: The "large" Roses are 2-year-old; "small," 1-year-old.

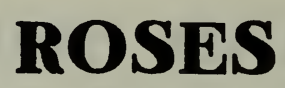

Order in spring, not later than June 1st

To obtain the most satisfactory results, roses should be planted in well drained, rich, deep loamy woll, and given a location where they will have sunlight and a circulation of air. For winter pro. tection an application of composite or rotten manure should be given them in the late autumn, and spaded into the ground the following spring.

\section{Hardy Hybrid Perpetual Roses}

\section{ANNOUNCEMENT}

To Our Patrons: To satisfy a particular and ever increasIng demand for 2-year-old roses we have been forced to erect veveral more large greenhouses for the exclusive propagation and growing of large quantities of roses and house plants. We propogate and grow all of our roses and the varieties listed are all tried and true to name. Our roses are grown in the fleld two years, and with the exception of Ram. blers, are taken up in the Fall. held dormant until towards Spring and then started in large 4-inch pots. When shipped to you they are in bud and bloom, with a ball of dirt on the roots which is wrapped with moss, paper and burlap and shipped by express at your expense, or by mail for 10c more. They should reach you in the finest condition.

\section{NOTICE}

If the plants look wilted when received put them in lukewarm water for 15 or $20 \mathrm{~min}$ utes. Set the plants about $2 \frac{1}{2}$ Inches deeper than they were crowing before and press the soil firmly around the roots. Give them a good watering. Shade from sun and wind until they begin to grow.

GEN. JACQUEMTNOT. A grand old rose which everyone knows at least by name and reputation. Rich, crimson scarlet in color and especially handsome in the bud. Although introduced nearly fifty years ago, it is still unrivalled in popularity and of great value for garden planting. Small 15c each: 3 for $40 \mathrm{c}$; large $55 \mathrm{c}$ each; postpaid. By express, $35 \mathrm{c}$.

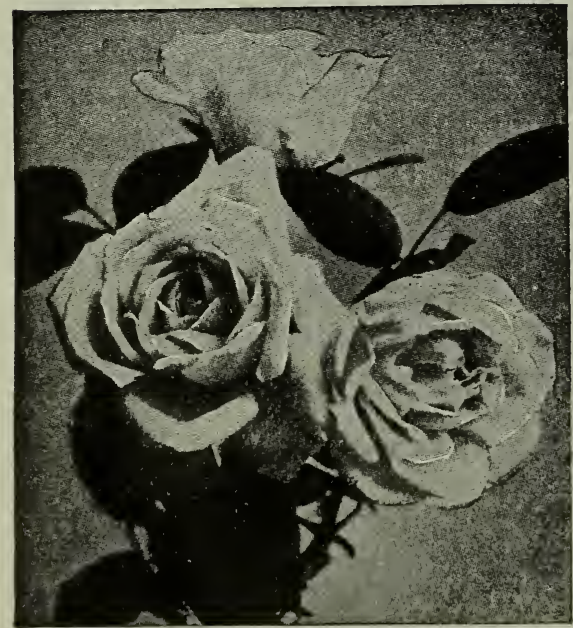

WHITE AMERICAN BEAUTY

PRIVCE CAMILLE DE ROHAN One darkest colored crimson, changing to intense maroon. A very prolific bloomer, and blooms are of excellent form and size. Small 15c each, 3 for $40 c$; large 45c; postpaid. By express, 35c.

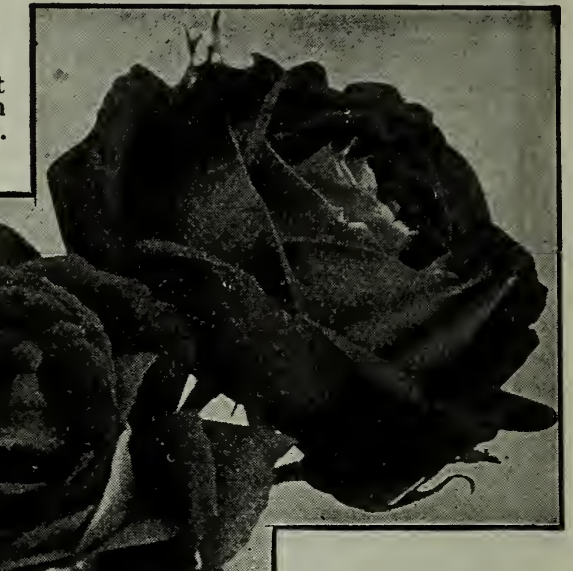
T I E R - T II C E M E T E R Y ROS E. Nerde No care. Th is g r a n d variet $\mathbf{y}$, when once planted, is as permanent as a Hydrangea. It is hardy as an Oak. We recom. mend it for cem. e te $r$ y planting because of its perma nency.

GEN. JACQUEMINOT

Flowers are pure white, very large and double: it is: profuse and continuous bloomer. Good white hardy roses are scarce-this is one of the very best. Should never be pruned except to remove old or scraggy branches. Small 15c each, 3 for $40 \mathrm{c}$; large $45 \mathrm{c}$ each; postpaid. By express, 35c.

PAUL NEYRON. The largest of all rose blooms, bright shining pink, clear and beautiful; very double and full; finely scented; blooms first season and all summer. Grows to a great height in a single season and stems are almost thornless. Small 15c each; large 50c; postpaid. By express, 40c.

SAFRANO. Bright apricot-yellow, changing to orangefawn, reverse of petals tinted with flesh pink; splendid buds and fine star-shaped flowers, vigorous, producilve and fragrant, constant bloomer. Small 12c each; large 45c; postpaid. By express, 35c.

WHITE AMERICAN BEAUTY. Extraordinarlly strong growing, branching freely, with the vigor and hardiness of an oak. An ordinary plant will produce hundreds of magnificent flowers, which are full, very deep and double and of splendid substance. Petals вгояd and long. The buds are egg-shaped, long and pointerl. The color is marvelous, snow-white, without a tinge of yellow, pink or any other color. If you want the hest and hardiest white rose in cultivation, this variety will meet your every want. Small 16c each; large 50c earh; postpaid. By express, 40c.

PAPA GONTIER. Extra large, finely formed buds and flowers; strong, robust grower; constant bloomer; rlich rosy red; very full and sweet. Small 12c each; large 45c each; postpaid. By express, 35c.

AMERICAN BEAUTY. Well known as one of the grandest and most beautiful constant. blooming roses; immense buds and flowers, rich glowing crimson, exceedingly sweet. Snıli 16c each; large 50c each; postpaid. By express, $40 c$ 


\section{Choice Standard Ever-Blooming Tea and Hybrid Tea Roses}

SUNBURST. A magnificent new giant yellow rose standing head and shoulders above all other sorts of its color. Extraordinarily vigorous and healthy. The buds are long, pointed and of a beautiful golden-orange to golden-yellow with intense shades, extremely brilliant in effect. Large only, \$1.10. By express, \$1.00.

SOUVENIR DE PRESIDENT CARNOT. A rose of extraordinary beauty; the color is lovely sea shell pink, delicately tinted with golden-fawn on rich creamy-white. Only large, 45c each; postpaid. By express, 35c.

CHERRY RIPE. An extraordinarily free-flowering Hybrid, branching in habit, vigorous and hardy, and as free as a Tea Rose. The flowers are medjum in size, well formed, globular, light rosy. crimson: as fragrant as the Hybrid Perpetuals. Large size only, 45c; postpaid. By express, 35c.

GRUSS AN TEPLITZ. Sucseeds under the most ordinary conditions. In color it is of the richest scarlet, shading to velvety crimson; a free, strong grower, quite hardy and a most profuse bloomer all summer. Foliage very beautiful. Small 12c each, 3 for 30 c; large 45 e each; postpaid. By express, 35c.

J. B. CLARK. The glory of the plant is its flowers. They are extraordinary in size; the half open bud full and elongated, with a high pointed center. The color is new-intense deep scarlet, heavily shaded blackish,-crimson like the sheen on a plum, giving the expanded flow. er an indescribably beautiful appearance. Frag. rance intensely sweet. Small 15c, 2 for 25c; large 50c each; postpaid. By express, 40c.

ETOILE DE FRANCE. Color, superb, velvety crimson with a vivid bright pink center. Buds are long and pointed, borne singly and erect flowers very large, valuable for cutting. Small $12 \mathrm{c}$ each, 3 for $32 \mathrm{c}$; large $45 \mathrm{c}$ each; postpaid. By express, 35c.

ETOILE DE LYON. This magnifleent Tea Rose is a rich golden yellow; a strong, healthy and vigorous grower, immense bloomer. Will withstand very well, both heat and cold. Small 12c each, 3 for 30c; large 45c each; postpaid. By express, 35c.

GOLDEN GATE. Rich, creamy white, beautifully tinged with golden yellow and rose; a constant

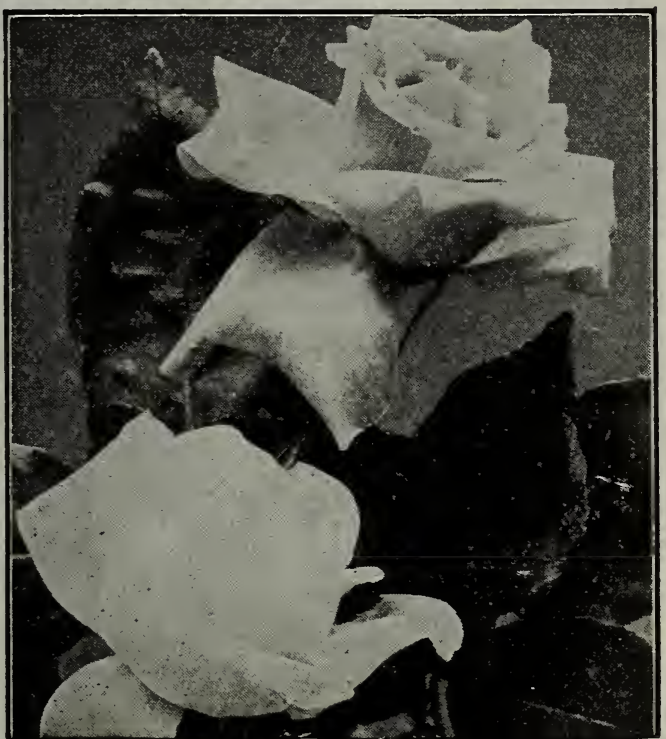

WHITE MAMAN COCHET

bloomer, large, very double Small 12c each: large $45 \mathrm{c}$ each. By express, 35c.

KAISERIN AUGUSTA VICTORIA. Color, pure, snowy white; a continuous bloomer, producins successive crops of buds and flowers in great. est profusicn. Buds and blossoms are beautiful and fragrant. Small 12c; large 45̆c; postpald. By express, 35c.

METEOR. Remarkable for its large size, con. stant bloom and brilliant color: bright. rich. velvety crimson, and a most constant and abundant bloomer. Small 12c each; large $45 \mathrm{c}$ each; postpaid. By express, 35c.

MADAME JENNY GUILLIMOT. Buds long and pointed, deep saffron-yellow, opening canary, with dark golden shadings; blooms large, petals immense; exquisitely beautiful. Large $45 \mathrm{c}$ each; postpaid. By express. 35c.

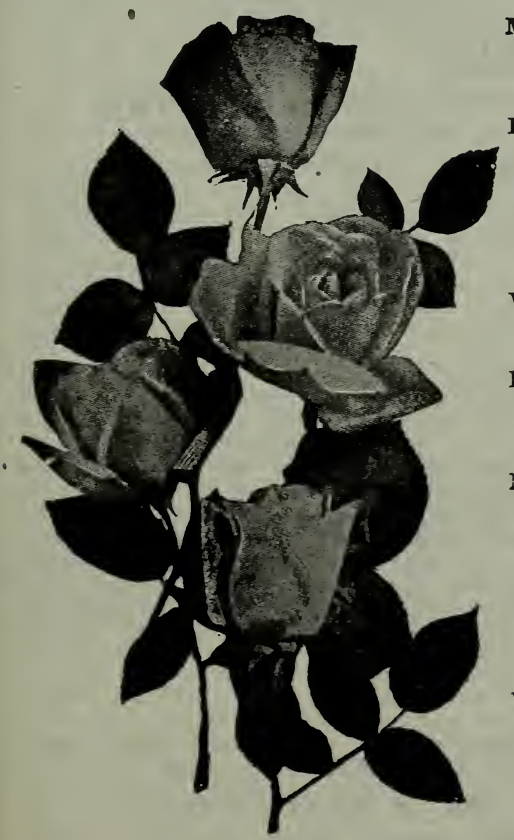

KILLARNEY

MY MARYLAND. Salmon pink of a soft and pleasing shade with long stems and long pointed buds, very full in bloom and exquisitely fragrant. Large only, 50c; postpaid. By express, $40 \mathrm{c}$.

KILLARNEY. There is no rose we know in this class that blooms more freely than Killarney and the large size of the flowers and substance of petals are remarkable, petals measuring $21 / 2$ inches deep. The buds are large, long and pointed. The color is ex. quisite, a brilliant imperial pink, almost sparkling and beautiful beyond description. Small 12c each; large 50c each; postpaid. By express, 40 c.

WHITE KILLARNEY. A pure white sort from the pink parent above described. Identical with the pink variety except in color. Small 15c each; large 50c; postpaid. By express, 40c.

DOUBLE WHITE KILLARNEY. Splendid new double white rose possessing all the good features of its pink parent, with a stronger growth and more petals. Only large, $\$ 1.10$; postpaid. By express, $\$ 1 \mathrm{M}$.

MAMAN COCHET. This superb rose is well known as the queen among roses and one of the best and most begutiful varieties ever grown and quite hardy. The flowers are of enormous size, very full and of great depth and substance. Color, rich, coral pink, elegantly shaded with rosy crimson, has broad, thick, shell-like petals and makes superb long pointed buds, immense bloomer, continues loaded with buds and flowers the whole season. Deliciously sweet and a hardy, vigorous grower. Small 12c each; large 50c each; postpaid. By express, 40c.

WHITE MAMAN COCHET. Identical with its parent Maman Cochet in everything except color, which is snow white, with sometimes a tinge of pale blush. It has the same freedom of bloom and same magnificent form of buds and flowers, and the same hardiness. Standing at the very head of all white roses for open grown culture. Very vigorous and hardy nearly everywhere. Small 12c each; large, 50c each; postpaid. By express, s0e. 


\section{THE THREE SOUPERT ROSES \\ 3 FOR $32 c$ POSTPAID}

Hardy. Bloom continuously. Will be a Source of Constant Pleasure.

In Ordering Give Simply the Name of the Collection

If you want Roses that will give you absolute satisfaction from the day they are planted, we would urge that vou plant these famous varieties. They bloom the first and erery year from early May unill severe freezing weather. We have sfin them unfold perfect flowers even after a serere snow storm. Of dwarf, stocky, uniform growth, they possess valuable qualities found in no other Roses. There are other Roses as good, but certainly none better. Be sure to try them.

CLOTHILDE SOUPERT. The best Rose known for bedding or pot culture. Color a French white, deepening to a rosy-blush in the center, exceeding in distiuctness of shading the well-known Malmaison. Its greatest ralue lies in its compact, vigorous habit and wonderful profusion of bloom, even the smallest plants being literally corered with flowers. The form and substance of the flowers are so perfect that the hottest weather does not cause deterioration of either, so that eren in mid-summer a bouquet of splendid buds and open flowers can be obtained from this fine rariety. Too much cannot be said in praise of this Rose for bedding purposes. It deservedly earned its title of the "Premier Bedding Rose." Vaiuable as it is for garden purposes, it is eren more so for pot culture, and ranks first for blooming in the house.

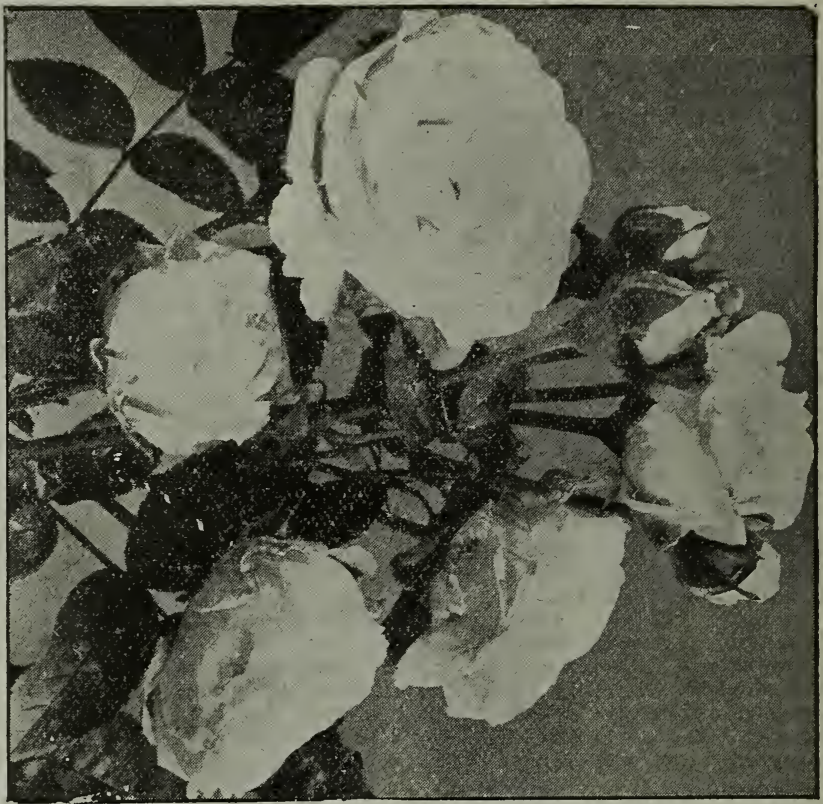

CLOTHILDE SOUPERT

It is entirely exempt from the diseases usuall $\Gamma$ affecting Roses in the House. Small 12c each; large $45 \mathrm{c}$ each; postpaid. By express, 35c.

MOSELLA. (Yellow Soupert.) Fully as free blooming as Clothilde Soupert or Pink Soupert, and like them, a strong, dwarf, bushy grower. Flowers are very double and of the same Camellia-like form as Clothilde Soupert. Buds exceedingly dainty and attractive. The color is white on beautiful light yellow ground, which becomes a chrome sellow in the center of the flower. Hardy, without protection as far north as New York City, and if protected dnring the winter with a mulch of leaves or straw it can be grown almost anwhere that other roses succeed. Small only, 12c each.

PINK SOUPERT. A lorely ever-blooming rose, as beautiful as Clothilde Soupert, but deeper color; medium size flowers. perfectly full and double; blooms all the time; color, fine rose pink, but variable. The same bush frequently bears flowers of different colors at the same time; grows low and bushy and is quite hardy. Small 12c each; large $45 \mathrm{c}$ each; postpaid. By express, $35 \mathrm{c}$.

\section{TWO ROSE SPECIALS}

\section{WEDDING BELLS COLLECTION}

One of each for $32 \mathrm{e}$; postpaid

THE BRIDE. (White Tea Rose.) Flowers rery large on long. stiff stems. They last a long time after leing cut, making it one of the best for bouquets. Some times a pinkish white in rers hot weather but usually a pure white. Small 12c each; large $45 \mathrm{c}$ each; postpaid. By express $35 \mathrm{c}$.

BRIDESMAID. (Pink Tea Rose.) A clear, snining pink, on long strong stems. Lasts a long time after cutting. A very fitting companion to the abore. Small $12 \mathrm{c}$ each; large $45 \mathrm{c}$ each; postpaid. Br express $35 \mathrm{c}$.

RICHMOND. (The Ererblooming Gen. Jacqueminot.) It is free blooming, and its scarletcrimson flowers are borne on fine, long stems, which make it especially valuable for cutting purposes. It comes to perfection without special care or culture. Produce freely throughout the year. long. pointed buds on tall, straight stems with elegant dark foliage. Has as delicious fragrance as American Beauty. Small 12c each; large $45 \mathrm{c}$ each; postpaid. Br express, 35c.

\section{THE “TRIPLETS" COLLECTION} One of each for $40 \mathrm{c}$; postpaid

BABY RAMbler. (Crimson.) Possesses all the charming. brilliant red color of the Crimson Rambler, only it is dwarf and ererblooming. Begins blooming when only a few inches high. $A$ plant in a or 6 inch pot is a thing of beauty. Also an excellent bedder, forming clus. ters of flowers as large as the Crimson Ram. bler. Small 12c each; large $45 \mathrm{c}$ each; postpaid. BY express, 35c.

BABY DOROTHY. A splendid companion to the crimson Baby Rambler; is just as vigorous and free blooming. This is much the same as the climber Dorothy Perkins, hence the appropriateness of the name "Baby Dorothy." As a pink bedding rose it has no equal. Small 15c each; large 450 each ; postpaid. By express. 35c.

WHITE BABY RAMBLER. This rose has identically the same habit of growth and freedom of bloom as the other two "Baby" roses. No collection of dwarf roses is complete without the White Babs Rambler. Small 15c each; postpaid.

\section{MOSS ROSES}

Moss roses are strong, vigorous growers, perfectly hardy and like rich ground. Both flowers and buds have an abundance of lorely deep green moss; very free flowering.

BLANCHE MORREAU. Flowers in clusters, and are large. fnll and sweet, pure white.

PRINCESS ADELAIDE. One of the best; extra large flowers; color bright ross pink.

CRIMSON GLOBE. A fine deep crimson.

Price of Moss Roses. Small, 15c each; three (one of each) for $40 \mathrm{c}$. 


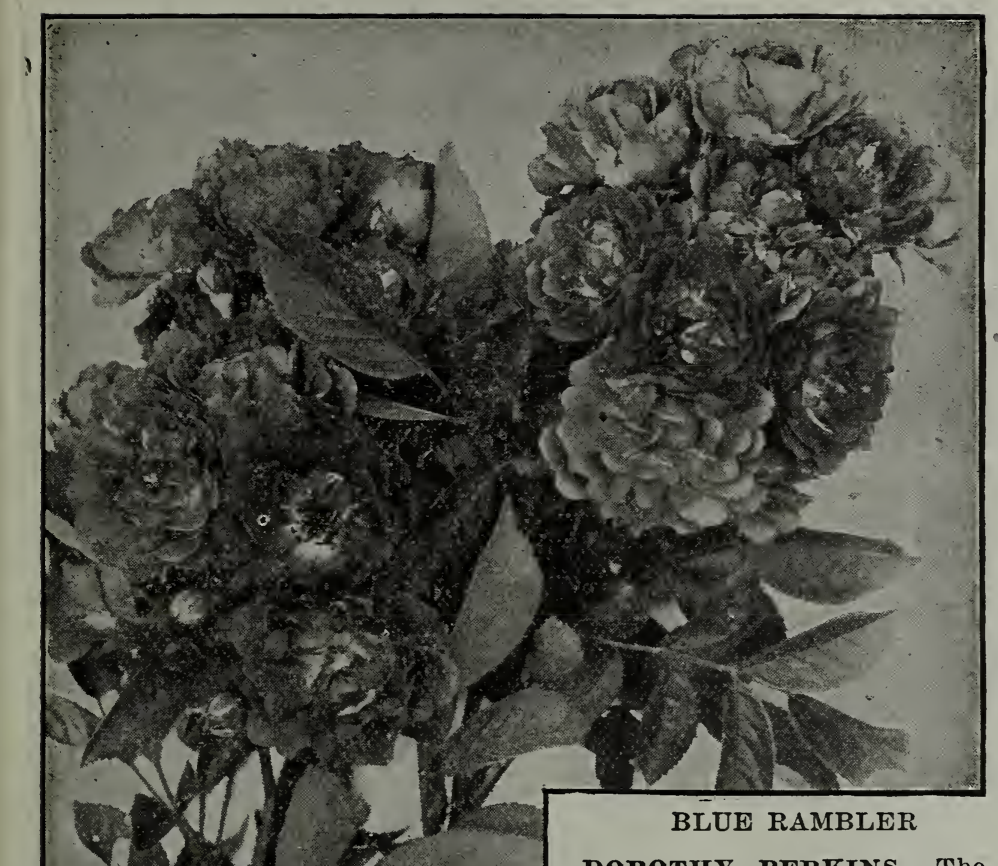

\section{HARDY CLIMBING ROSES}

Orders for Roses in this lis should reach us by April 15 at the latest.

BLUE RAMBLER. Veilchenblau. (Violet Blue.) For years it has been the endearor of rosarians to produce the blue rose, and their efforts have at last succeeded in the produc. tion of Veilchenblau. The semi-double flowers come in clusters similar to the Crimson Rambler. When first open, they are partly bright red, partly bright rose but soon change to a steel blue. It is a hardy, vigorous grower and is not troubled by mildew. Small 15c each, 3 for $40 \mathrm{c}$; large 5ic each; postpaid. By express, 50c.

CRIMSON RAMBLER. It is a vigorous grower, making a gorgeous display of brilliant crimson clusters of blossorns, each cluster a bouquet in itself. The blooms remain on the plant for a long time without losing their brightness. small 12c, 3 for 30c; large $40 \mathrm{c}$; postpaid. By exp. 35c.

DOROTHY PERKINS. The flowers are a most beautifial shell pink and hold a long time without fading. About one and a half inches across; are borne in clusters of from ten to thirty and are very double; the petals are very prettily rolled back and crinkled; the buds are remarkably pretty. In hardiness, vigor and habit of growth it is all that can be desired. The foliage is of deep green, of thick, leathery texture, and remains on the plant in perfect condition till well on into the winter, making it almost an evergreen variety. Small 12c each, 3 for 30c; large 40c each; postpaid. By express, 35c.

EVERBLOOMING CRIMSON RAMBLER. (Flower of Fairfield.) The Flower of Fairfield is in form and color like the ordinary Crimson Ram. bler. It begins blooming early in srping and continues to produce repeated crops of bloom until late in autumn. This rose is not only good for covering trellises but is excellent for cutting. Small 15c each, 3 for 40 ; large $55 \mathrm{c}$ each; postpaid. By express, 50c.

LADY GAY. Flowers are deep, clear rich rose pink; immense trusses like Crimson Rambler. Healthy, hardy and very rapid grower. Large size only, $40 \mathrm{c}$; postpaid. By express, 35̌c.

PHILDELPHIA RAMBLER. Blooms two weeks earlier than the Crimson Rambler. Flowers are perfectly double, borne in large clusters, completely covering the bush. Small 12c each, 3 for $30 \mathrm{c}$; large $40 \mathrm{c}$; postpaid. By express, 35c.

TAUSENDSCHON. (Thousand Beauties.) The flowers appear in large clusters from the beginning of June to the end of July. The color is a soft pink changing to a rosy carmine. Small $15 \mathrm{c}$ each, 3 for $36 \mathrm{c}$; large $40 \mathrm{c}$; postpaid. By express, 35c.

THALIA. (White Rambler.) Produces immense clusters of pure white roses perfectlo double, of delightful fragrance. Large size only $40 \mathrm{c}$; postpaid. By express, 35c.

HARDY WHITE MEMORIAL ROSE, WICHURAINA. Will creep all over the ground or can be trained up to a trellis. Hardy as grass, and will grow in sun or shade, poor ground or rich. Needs no protection, will care for it: self and bloom profusely every season, without attention. The flowers are single and very large, pure satiny white, with bright golden center. Borne in clusters. Small 12c each, 3 for $30 \mathrm{c}$; large $40 \mathrm{c}$ each; postpaid. By express, 35c.

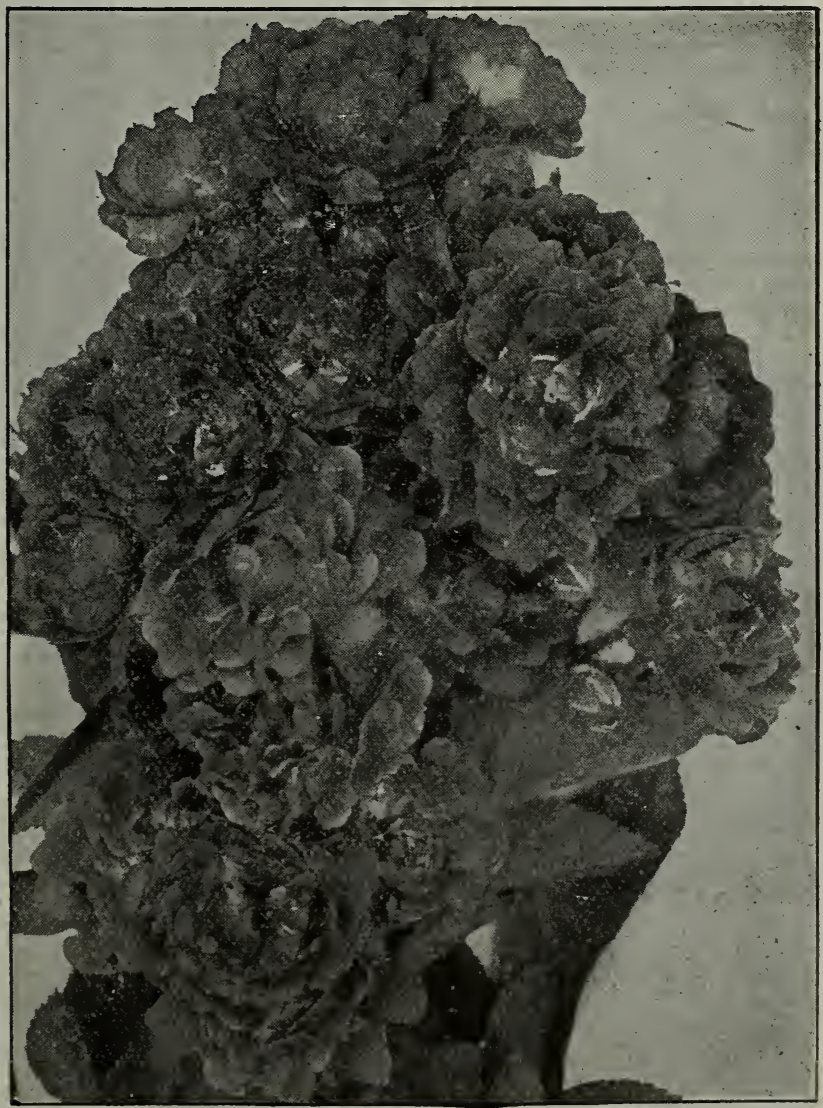

FLOWER OF FAIRFIELD 


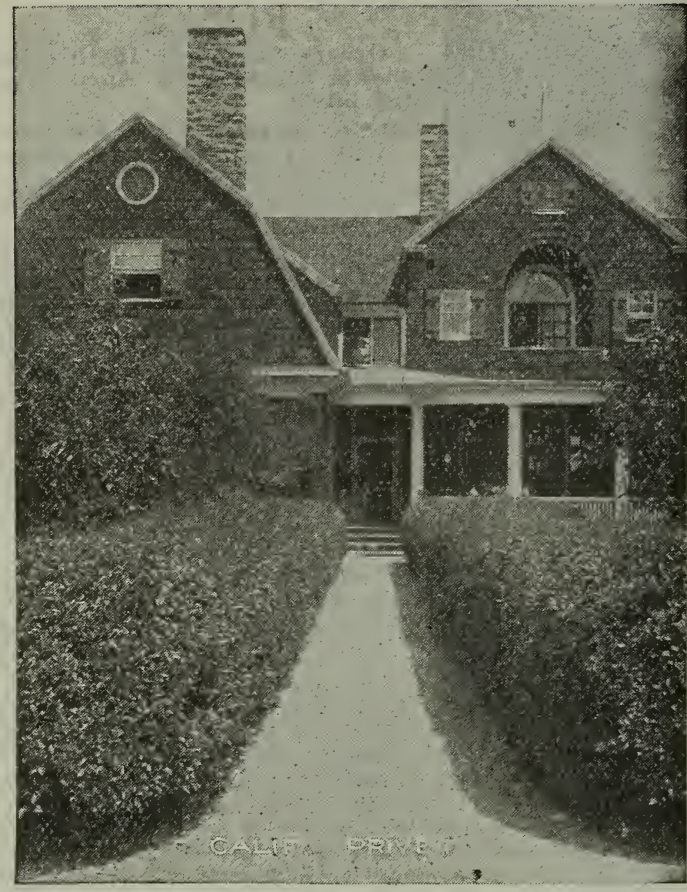

PRIVET

Amoor River. Much hardier than any other. Stood last winter without killing. The foliage is glossy green, holding its color almost the entire year. Will stand any kind of shearing. Price, is to 24 inches, well branched, $\$ 1.00$ per $10 ; \$ 8.00$ per 100 , by express.

California. (Lingustrum.) No plant has come more rapidly and deservedly into public favor as a hedge Is of vigorous growth, has glossy dark green foliage, keeping its color until after Christmas. Almost evergreen, 40c per $10 ; \$ 3.50$ per 100 , by express.

FLOWERING CURRANT. $A$ n attractive shrug with fragrant golden-yellow flowers and deep scarlet fruit. $40 \mathrm{c}$ each, by express.

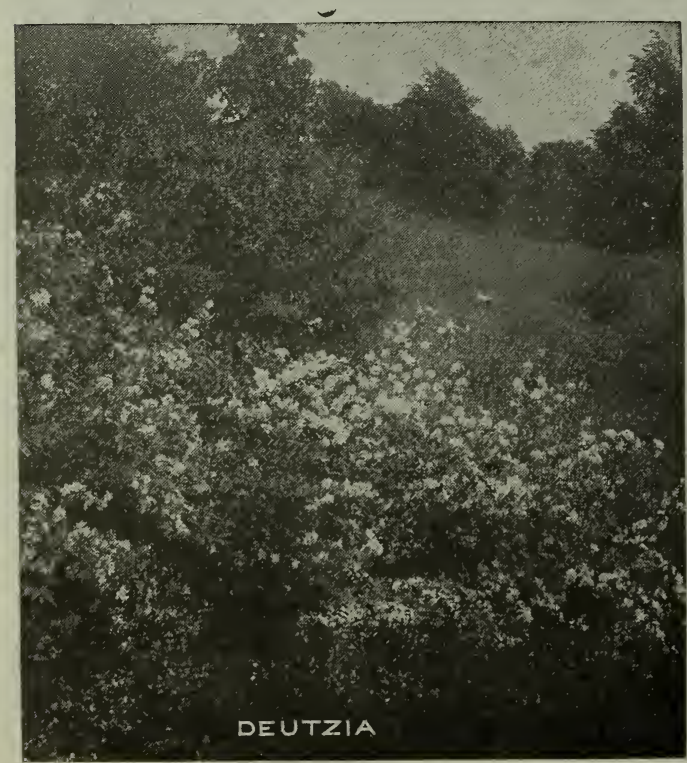

\section{Ornamental Shrubs}

We pay all express charges on orders amounting to $\$ 5.00$ or more.

There is nothing which so quickly, and for so little cost, adds so much to the beauty, cheerful. ness and home-like appearance of a place as an assortment of hardy shrubs. They are permanent improvements which increases in size, value and beauty, year after year. Our price is for strong, healthy, field grown plants, 3 year old and 4 to 5 feet high.

BARBERRY. (B. Thunbergii.) From Japan; of dwarf habit, small foliage, changing to a beautiful coppery red in the fall; is very ornamental when used as a hedge. 60 c per $10 ; \$ 5.00$ per 100 , by express.

Purple Leaved. (B. Vulgaris.) Grows three to flve feet high; foliage and fruit violet purple; very effective in groups or masses; yellow blosscms. 90 per $10 ; \$ 8.00$ per 100 by express.

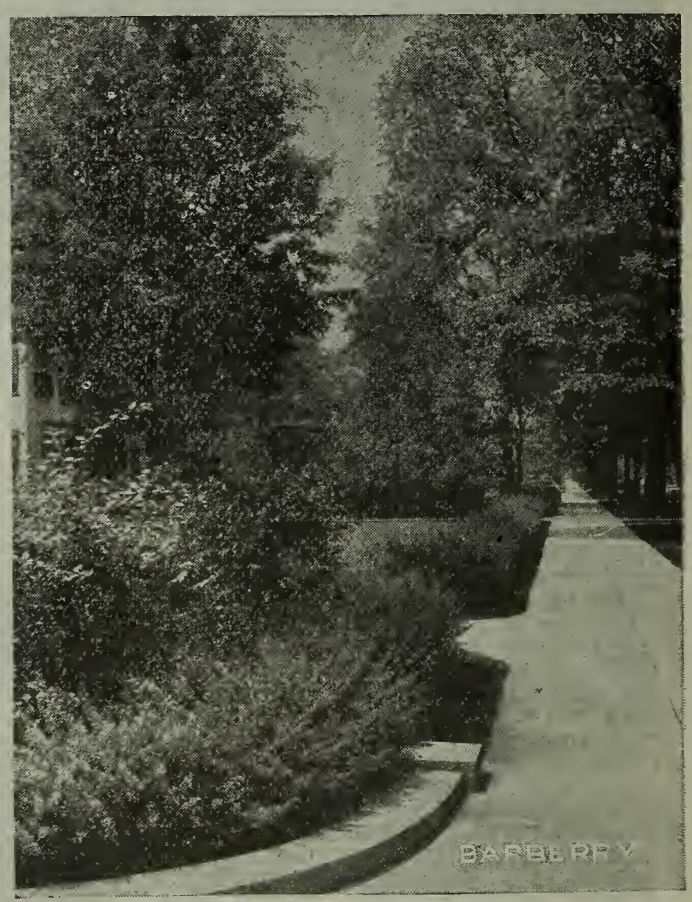

SIBERIAN DOGWOOD. (Cornus.) A very brilliant shrub in early spring, when the bark is intensely colored. Free growing, 6 to 10 feet tall, and very hardy; forms a small, handsome tree in some situations; its clusters of small, white flowers in early summer are very dainty, and its bark is a showy red in winter. In early fall it bears a profusion of whitish blue berries, making it distinctly ornamental after the flowers have gone. 50c each; by express.

DEUTZIA PRIDE OF, ROCHESTER. The large Flowered Deutzia. A vigorous grower, profuse bloomer, and one of the earliest to come into bloom. Flowers large double white, slightly tinged with rose. The plant grows 3 to 4 feet tall. Desirable for groups and as a specimen plant on the lawn. $50 \mathrm{c}$ each, by express.

FLOIVERING ALMONDS. (Prunus.) The Flowering Almonds are pretty dwarf bushes that bloom quite early and are very showy in spring. Their slender, leafless, upright branches are entirely hidden by stemless, very double flowers resembling small roses. Grows to a height of 4 to 5 feet and blooms in May, One hef the best flowering shrubs and can be highly of the best flowering shrubs an states. Pink or recommended for the Wester 


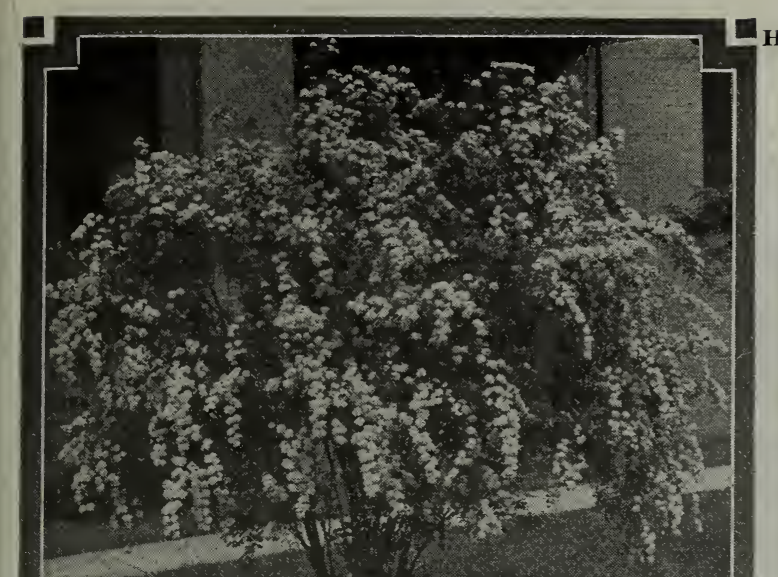

HYDRANGEA, Paniculata Grandiflora. The large flowering. Hydrangea. Without questiou, the most popular of the Hydrangeas, as well as one of the showiest of all shrubs. The flowers are borne in immense pointed clusters. nearly a foot in length, creamy white when fully expanded, and continuing in bloom for a long time. Later the huge flower-heads change to tones of rose and bronze where exposed to the sun. The brush grows 4 to 6 feet tall. Unsurpassed for the lawn, for hedges, parks or cemetery planting. 50c each, by express.

American Everblooming. This new Hydrangea is the most beautiful hardy shrub introduced in the last twenty years. It attains a height of 5 to 6 feet with nearly the same breadth, with large trusses of beautiifully formed flowers of dazzling whiteness and peerless beauty. 'The flowers are very full and round as a ball. resembling the Snowball shrub. Its hardiness and vigor have been well tested in all parts of the country. It is a continuous bloomer. Price 2 to $3 \mathrm{ft}$., $60 \mathrm{c}$, by express.

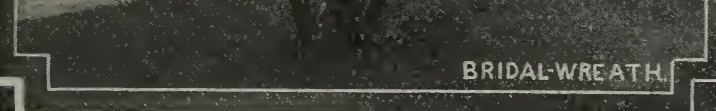

FORSYTHIA. (Golden Bell.) Few, if any, of the hardy shrubs can surpass the splendor and brilliancy of the Forsythia. The i grace a n d beauty give them a prominent place in ail shrub plantations. Of upright, $\nabla$ i g o r o us growth; foliage rich dark green and lus. trous. Flowers brilliant golden yellow, borne in great profusion early in April. before the leares appear. $40 \mathrm{c}$ each by express.

SPIREA, Van Houtti. (Bridal Wreath.) The $\mathrm{grandest}$ of all spireas. Very beautiful for the lawn. When in bloom it is a perfect fountain of white blossoms, the foliage hardly show. ing. Perfectly hardy and vigorous grower A very good plant for a fancy hedge. Grows 4 to 5 feet high, and blooms in early June. 40c each. by express.

Anthony W at erer. This beautiful variety produces flowers of a bright crimson and blooms so freely that it may be kept flow. ering throughout the summer till late fall by trimming away the dead blooms. The foliage also is very handsome, being variegated with creamy white or yellow. $40 \mathrm{c}$ each, by express.

Thunbergii. (Snow White.) A Japanese variety of medium size, with narrow, delicate leaves and a profusion of small white flowers in early summer. One of the best. Leaves narrow, bright, green, turning in a utumn to brilliant shades of orange and scarlet. Grows 3 to $4 \mathrm{ft}$. high. Price $\mathbf{2 - 3}$ ft., each $40 \mathrm{c}$; postpaid.

SNOWBALL. The old-fashioned, common snowball; grows 6 to 8 feet high; its large globular clusters of pure white flowers are produced in May and June and make a very attractive appearance. $40 \mathrm{c}$ each, by express.

SCARLET JAPAN QUINCE. One of the best flowering shrubs; flowers a bright scarlet crimson, borne in great profusion in early spring; foliage retains its color of bright glossy green the entire summer; hardy; makes a good hedge. $40 \mathrm{c}$ each: hedge size $\$ 1.50$ per $10 ; \$ 12.00$ per 100 , by express.
HONEYSUCKLE, U PRIGH'T RED TAR'TARIAN. The best known of all the Bush Honeysuckles and in our estimation the finest $\mathbf{v a -}$ riety of all. Grows to a height of 8 to 10 feet with upright somewhat spreading branches and bright $\mathrm{gree} n$ foliage. The flowers are borne freely in May and June, are of bright pink color, followed by showy red berries, which ripen in midsummer, and cling to the bush for several weeks. This fine shrub is of great value planted as a background for smaller shrubs. It with. stands successfully the severest winters. $50 \mathrm{c}$ each, by express.

\section{LANDSCAPE GARD-} ENING

By F. A. Waugh, Prof. of Landscape Gardening in Mass. Agri. College. The whole matter of Landscape Gardening is made entirely plain even to the inexperienced reader. :llus. trated, 152 pages. Cloth

\section{JAPANESE QUINCE}

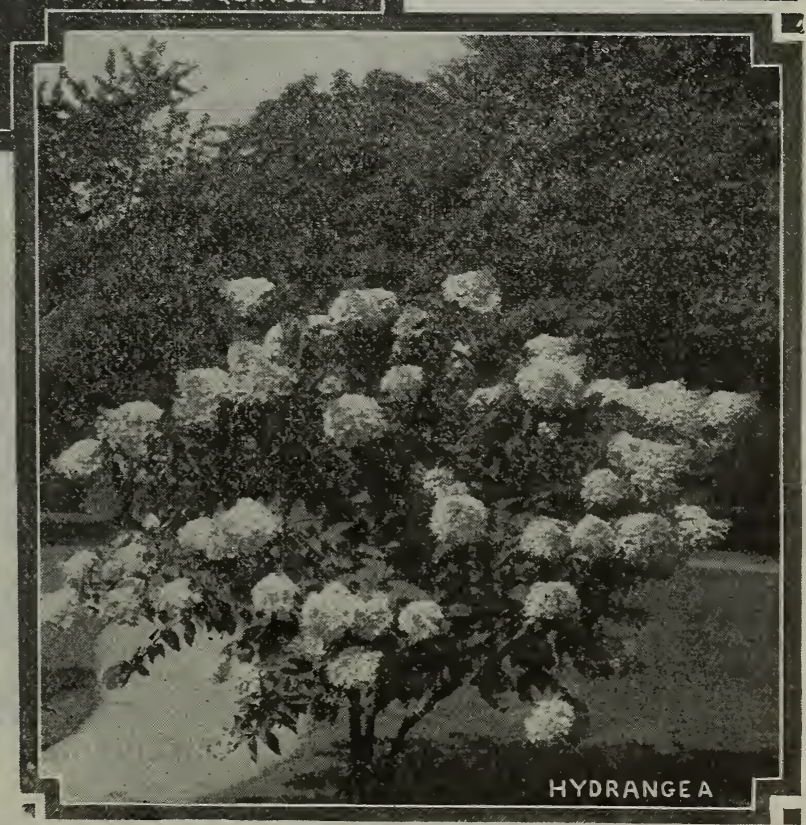




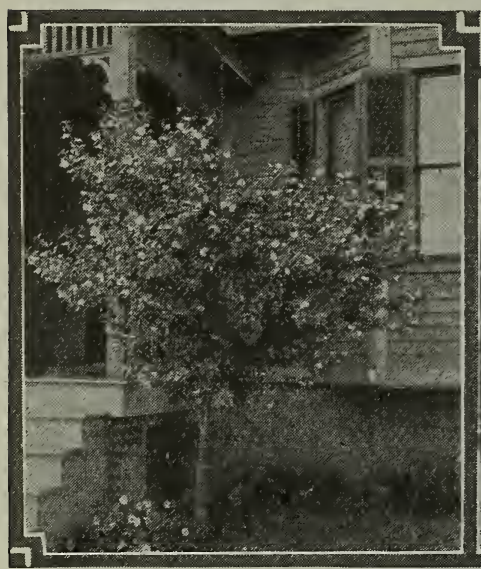

DOUBLE FLOWERING CRAB

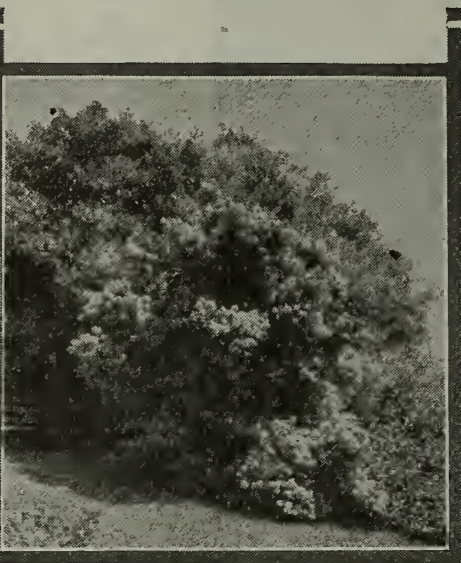

SMOKE TREE

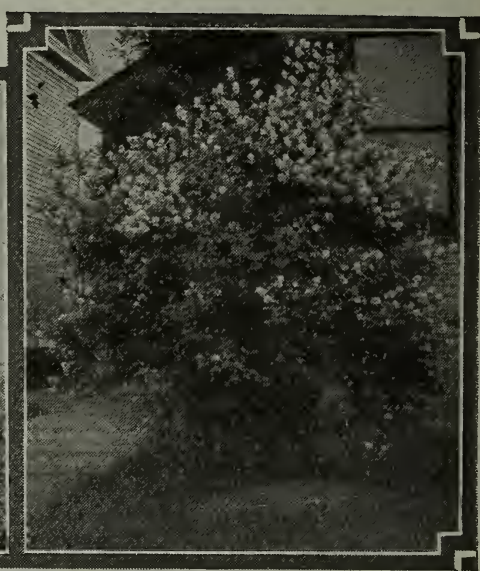

MOCK ORANGE

DOUBLE FLOWERING CRAB. One of the most beautiful af the many fine varieties of flowering crabs. Tree of medium size, covered in early spring with large, beautiful, double fragrant flower's of a delicate pink color. From a distance the flowers have the appearance of small roses. Tree blooms when quite young, 4 feet. $60 \mathrm{c}$ each, by express.

SNOWBERRY Or WAXBERRY. (Red or White Fruited.) A desirable shrub with small pink flowers, followed by large wax-like berries, which hang on the plant through most of the winter. Grows to a height of 2 to 4 feet. Very showy and succeeds everywhere, of special value for planting in densely shaded places where few other shrubs will grow. Price of trees, 3 to 4 feet high, 50c, by express.

PURPLE FRINGE or SMOKE TREE. A variable ornamental shrub; has curious fringe or hairlike flowers that cover the whole tree, giving the appearance of mist or smoke; wide spreading habit which requires some room to grow to the best advantage. $50 \mathrm{c}$ each, by express.

LILAC, PERSIAN. The old-fashioned Lilac, which grows into a very high bush with bright green, heart-shaped leaves. In May the plant is crowned with its wondrous wealth of flowers in clusters. It is, without doubt, the best known and most popular shrub grown. A fine, tall shrub for the lawn and one of the best for a fancy hedge. Can be used to good advantage in making effective backgrounds for smaller shrubs. Hardy everywhele. Purple or white. 50c each, by express.

WEIGELIAs. Beautiful shruhs, that bloom in May, June and July. The flowers are produced in so great profusion as almost entirely to hide the foliage. They are very desirable for the border or for grouping, and as specimen plants for the lawn.

Candida. Flowers pure white, produced in June and continue to bloom nearly all summer.

Eva Rathke. Beautiful flowers with a clear, distinct shade of brilliant crimson.

Rosea. An elegant rariety with fine rose colored flowers appearing in June.

Price of above Weigelias 50c each, by express.

For Insecticides and Sprayers, see pages $70-71$.

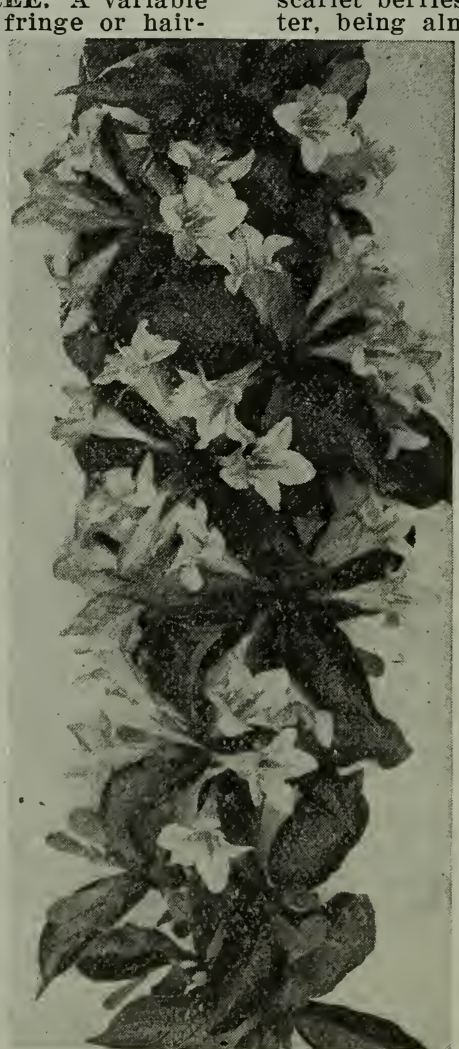

WEIGELIA
MOCK ORANGE or SYRINGA. (Philadelphus.) A hardy, upright growing shrub with arching branches, attaining a height of 8 to 10 feet. Flowers are large, creamy-white, deliciously fragrant, and appear in greatest profusion in May and June; splendid for cut-flowers. Hardy everywhere and valuable for immediate effect in landscape planting. Fine for hedges. The Mock Orange is one of the old-fashioned shrubs that add beauty, grace and perfume to our gardens. $50 \mathrm{c}$ each, by express.

HIGHBRUSH CRANBERRY. A magnificent large shrub, with upright, spreading form, and bright green foliage. The small, white flowers appear in May or June, borne in glorious, showy clusters in such profusion that it is admired by everyone. These are followed by very showy scarlet berries which cling to the bush all win. ter, being almost as effective as the flowers in summer. It will thrive and grow to perfection in the coldest climate. 50c each, by express.

GOLDEN ELDER. (Sambucus Aurea.) A variety with golden yellow foliage. A valuable plant for producing contrast when planted with other shrubs. Grows to a height of about 6 feet, and is of vigorous, spreading habit. In early summer it bears large, flat clusters of small, fragrant white flowers, followed by heavy clusters of black, edible berries, borne in profusion and bearing the branches down. Should have full sun to give best effects. Grows well on all soils and can be pruned into a neat, compact little bush. One of the best golden foliaged shrubs. $50 \mathrm{c}$ each, by express.

TAMARIX. Very strong growing shrub with brown bark and slender, spreading branches. The foliage is as light and feathery as asparagus; flowers delicate and fringing, of bright pink color. Blooms in May or June and sometimes again in the fall. Valuable for planting near the seashore or on the edge of sandy banks near fresh water. Will grow 10 to 12 feet high. Price, 3 to 4 feet high, $50 \mathrm{c}$, by express.

We cannot ship Nursery Stock into Wyoming. 


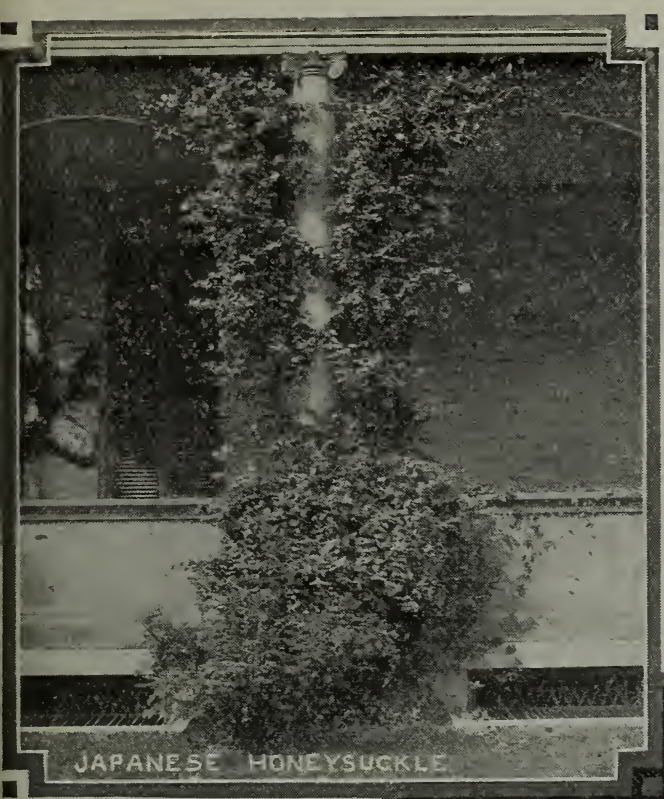

\section{Hardy Ornamental Climbing Shrubs}

Your home, out-buildings, fences and trunks of old trees can be made rery attractice by the use of hardy rines. Such permanent improrements adil greatly to the value of your property, and the value increases from year to year. We furnish nice, strong, field grown plants at prices given below.

\section{AMPELOPSIS}

Americar Ivy or Virginia Creeper. (A. quinqueflolia.) One of the finest vines for corering walls. rerandas or trunks of trees; foliage green, turning to a rich crimson in autumn; a rapid grower and quickly fastens to anything it touches. Large 30c each; postpaid.

Boston Iry. (Veitchii.) Leares smaller than the American; forms a dense sheet of green as leares orerlap each other; is a little difficult to start, but when once established requires no further care; foliage changes to a crimson scarlet in the fall, rery raluable for covering brick or stone structures. rookeries, walls, etc. Small 12c each, 3 for $30 \mathrm{c}$; large $35 \mathrm{c}$; postpaid.

\section{LARGE FLOWERING}

\section{CLEMATIS}

Jackmanii. The beautiful intense violet-purple flowers, when fully expanded, measure 4 to 6 inches in diameter. It blooms continually from July until frost.

Small 15c each, 3 for $40 c$; large 50c; postpaid.

Madame Andre. A free bloomer with crimson flowers. Small 15c each, large 50c; postpaid

Henryii. Has very large creamy white flowers. Small 15c, large 50c; postpaid.

Coccinea. A bright coral red bell-shaped flower. A profuse bloomer. Large only, 45̄c: postpaid.

JAPAN CLEMANTIS

Paniculata. One of the most vigorous, rapid and beautiful of all climbers. In late summer it produces dense sheets of m e d i u m sized, p u r e white flowers, of the most pleasing fragrance.

Will grow in almost any soil, and is entirely free from blight and insects. Small 14c each, 3 for $35 \mathrm{c}$; large $40 \mathrm{c}$; postpaid.

\section{HONEYSUCKLE}

Hall's Japan. A strong, vigorous vine with pure white flowers, changing to yellow; foliage remains green well into winter; very fragrant and corered with flowers almost the entire season.

Monthly Fragrant. Blooms all summer; flowers red and yellow and very fragrant.

Scarlet Trumpet, One of the handsomest in cultiration; a strong, rapid grower; flowers a bright scarlet, not much odor.

All Honeysuckles, price: Small 12c each, 3 for $30 \mathrm{c}$ large 45̃c each: postpaid.

YELLOW TRUMPE'T. A strong vine with brightest orange-yellow trumpet-shaped flowers. Large only $45 \mathrm{c} ;$ postpaid.

BIGNONIA or TRUMPET CREEPER. S carlet trumpet flowers with long, handsome dark green foliage and quite showy clusters of orange and scarlet flowers during the summer. Large only, 45c each; postpaid.

WISTARIA. Chinese Purple. Bears in great profusion large, drooping clusters of purple peashaped flowers, somewhat resembling a bunch of grapes in size and form. Blooms in May and June. Foliage is very pretty, of pale green colur. An exceedinglv beautiful and useful climbing plant. Small 12c each, 3 for $30 \mathrm{c}$; large 4 5̆c each: postpaid.

Chinese White. Same as the purple except color Small $16 \mathrm{c}$ each; large $45 \mathrm{c}$ each; postpaid.
Engelmanii Iry or Woodbine. It has shorter joints, smalle r and thicker foliage than Boston Iry. It is better equipped with tendrils with which to climb c los e l $\mathrm{y}$-built walls of stone or brick. It is the best Iry to be planted in the central and northwestern states, as it is perfectly hardy, withstanding both heat and cold. Small $12 \mathrm{c}$ each, 3 for $30 \mathrm{c}$; large $35 \mathrm{c}$; postpaid.
HEDGES, WINDBREAKS A N D LIVE FENCES. BY Powell. Accurate directions how to plant and care for live hedges. It includes the whole art of making the home grounds beautiful. Illustrated. $140 \mathrm{pp}$. Cloth 50c. 


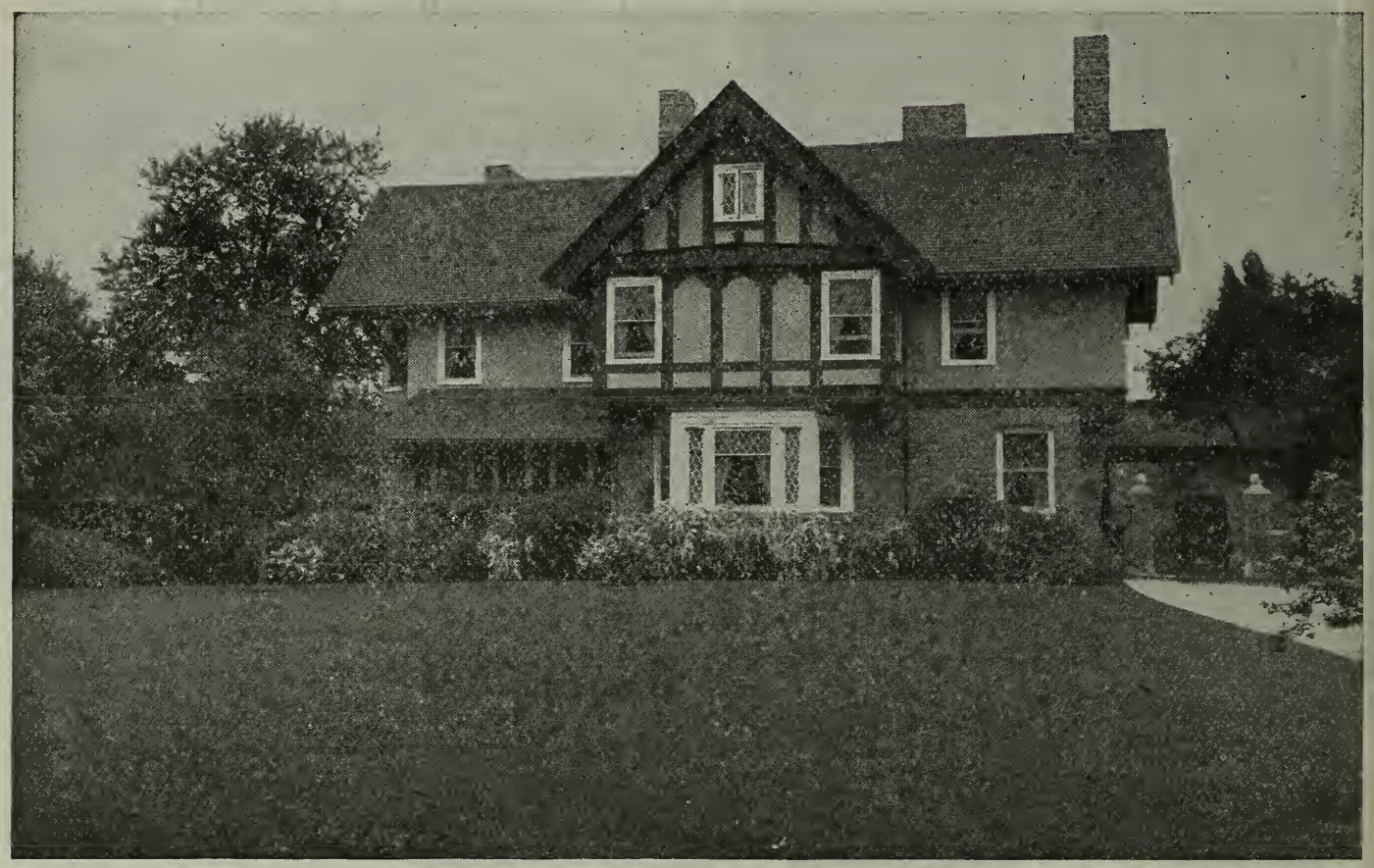

\section{BEAUTIFUL LAWNS}

A rich velvety lawn with a background of Beantiful Ornamental Shrubs enhances the value of a home and gives to it the natural artistic setting that we so much admire. We can furnish all Ornamental Shrubs, Vines and other plants to make your home as beautiful as the above. See pages 58 to 61 .

To Make a Good Lawn.-Wothing is more easily made and kept in order by a little well directed care. To get grass seed up quickly and evenly the surface must be mellow and level, with at least six inches of good black soil. Sow one

\section{LAWN SEED}

SPECIAL LAWN GRASS MIXTURE. A mixture adapted to our hot, dry climate. It is composed of Blue Grass, White Clover, and several other best lawn grasses. Some of these come early, some grow best during the summer, some grow well in the shade, while others make their growth in the fall. In this way one has green grass the whole season. This mixture will make a rich, deep green, velvety lawn, with a close, thick turf, in a few weeks' time, and one that will last much better than if sodded.

One pound covers 400 square feet (a space $20 \times 20$ feet) for new lawns, and half this amount for pound of Griswold Special Lawn Mixture to every 400 square feet, rake the seed in and roll well, or use a wide board until soil is uniformly firm. If the soil is clayey, cover the surface with a light coating of our Lawn Fertilizer. To keep the lawn beautiful, it must be frequently mowed. In hot, dry weather it is better to mow the law:n and not remove the clippings, as these will gradually form a thin mulch which will hold moisture, and protect the roots from the hot sun. Never water a lawn when the soil and grass are hot. The best time for watering is in the early morning before sunrise.

re-seeding old ones. Per lb., 35̌c; 5lbs., \$1.อ̃0. By mail, lb., $45 \mathrm{c} ; 5$ lbs., $\$ 2.00$.

FANCY KENTUCKY BLUE GRASS. Best grade of fancy, clean, new crop tested seeds. Per lb., 35c; 5 lbs., $\$ 1.50$; postpaid. By freight. 1 lb., 25c; 5 lbs., $\$ 1.00$; bu. (14 lbs.), $\$ 2.25$.

WHITE CLOVER. This is just the seed to sow on the bare spots in your yard or lawn where a very quick green covering is desired, as it will cover better in ten days' time than grass seed will cover in two months. $60 \mathrm{c}$ per lb., by masl. By express or freight, 50c per lb.; 5 lbs., \$2.40; $10 \mathrm{lhs} . \$ 4.7 n$. Prices subject to change.

\section{The "Fountain" Lawn Sprinkler}

\section{One of the REALLY GOOD things}

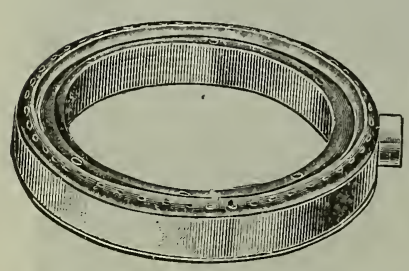

Ma de entirely ol brass

No moving parts

Nothing to get out of order

More beautiful than a fountain, more efficient than a shower. Price 65c.

\section{PERFECT SPRINKLER}

As gentle and even as the rain drops.

Top made of brass, bottom heary galvanized iron. Price $45 \mathrm{c}$ each.

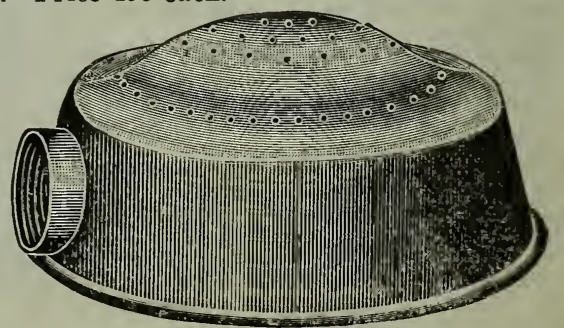




\section{BETTER LAWN HOSE}

\section{Fully Guaranteed}

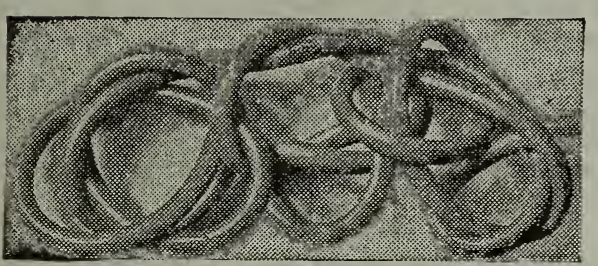

\section{Revero Non-Kinkable Hose}

\section{LIGHT-STRONG-FLEXIBLE}

An indestructible moulded hose for Lawn, Greenhouse, Stable, Garage. Of braided construction; can. not unirrap, kink or burst. Made in continuous lengths up to 500 feet, which gives you any length you want and avoids leaky couplings. Price $1 / 2$ inch size, per foot, $15 \mathrm{c}$.

\section{Regular Guaranteed H ose}

This hose is stamped with out own name and we will replace if not saisfactory.

$1 / 2$ inch Griswold's Windsor, 50 feet for. $\$ 4.50$

$3 / 4$ inch Griswold's Windsor, 50 feet for

$1 / 2$ inch Griswold's Greenwich, 50 feet for........ 5.25 Hose Menders with Bands, each.

Hose Gaskets (rubber washers), per dozen..........10;

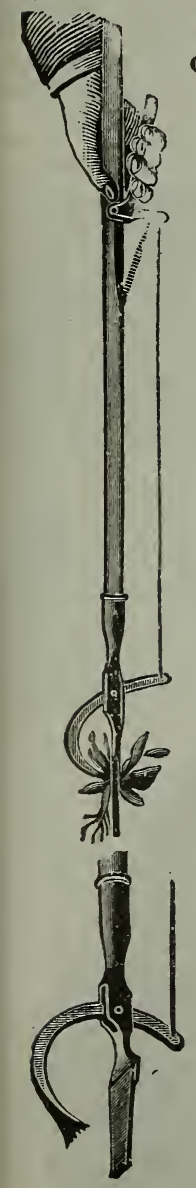

C L E V E L A N D L A W N WEEDER. A simple working devi ce for ridding lawns of all weeds. Dan: delions and Plantains a $\mathrm{r}$ e easily killed by its use. It gets at the root of the evil and removes it bodily. Handle $4 \mathrm{ft}$. long. Price 55c.

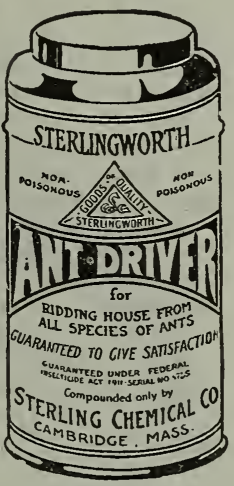

ANT DRIVER. This is effective against most of the known species, especially the small red and black ant, which are the most troublesome in this country. Price 25c.

\section{Fertilizer and Weed Killer}

LAWN BONE FERTILIZER. Co m p o s ed mainly of fine, ground bone. It is clean and dry and furnishes just the desired element for young plants, and gives to the grass a permanent, rich, green color, so much desired. It can be sown easily by hand. On new lawns it should be sown same time as the seed, and on old lawns any time in the early spring. It furnishes the same nourishment as manure. One hundred pounds covers surface of $75 \times 75$ feet. 25 lbs., 85c; 50 lbs., \$1.50; 100 lbs.. $\$ 2.75$.

SWARD FOOD. For lawn use, cemetery purposes or public grounds; it is a splendid feeder for turf, and quick in the result. It is free from any unpleasant odor. Its action is quick and lasting. Apply early in the spring to start the grass; it will fairly make it jump for joy.

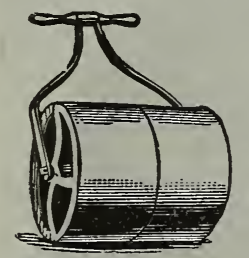

LAWN ROLLER

15 inch, weight 150 lbs. Price $\$ 7.50$.

NOZZLE

Regular Hose Nozzles. $35 \mathrm{c}$ each.
ORNAMENTAL GARDENING FOR AMERICANS. By Elias A. Long, Landscape Architect. A treatise on beautifying homes, rural districts and cemeteries. A plain and practical work with numerous illustrations and instructions so plain that ther may be readily followed. 300 pages. $5 \times 7$ inches. Cloth $\$ 1.50$.

BEAUTIFYING HOMES. By Weideman. This, the most elegant and useful work on the subject ever issued in this country. A superb quarto rolume. It is beautifully illustrated with numerous fine wood engravings, and with serenteen full page and seven double-page colored lithographs of places already improred. It contains general directions for lawns, roads and drives, walks, hedges, trees and shrubs, gardens, ornamental grounds, hints on burial lots, etc. The beautifully colored plans of improved places are accompanied by descriptions, giving the names and positions of the rarious trees and shrubs employed in planting, thus providing a complete planting map. $11 \times 14$ inches. Cloth $\$ 10.00$.

Sprinkled on the earth where ornamental or fruit trees have been dug around, is soon washed into the ground and taken up by the roots, giving beneficial and marked results to fruit and leaf. Vegetables and flowers may be treated with like results. It makes flowering vines of all sorts grow with great rapidity. $5 \mathrm{lbs}$. (enough for 400 square feet), $25 \mathrm{c}$.

SPECIAL LAIVN FERTILIZER. Composed of pulverized sheep manure and chemical fertilizers. The sheep manure is put through a heating process that not only eliminates the odor and turns it to a fine pulrerized mass but it also kills all weeds. $100 \mathrm{lbs}$. covers $75 \times 75 \mathrm{ft}$. Price $\$ 1.75$ per 100 lbs.

WEED KILLER. This is a preparation to be used on driveways, walks tennis courts or places that you wish to keep free from weeds. It will kill all kinds of weeds or grass, both top and roots. To be diluted with 50 parts of water. Price, pint cans, $45 \mathrm{c} ; 1 / 2$ gal. cans, $65 \mathrm{c}$; gal. cans, $\$ 1.00$. 


\section{NURSERY STOCK}

While this is the first year we have cataloged fruit trees it does not mean that it is a new department with us, for we have been handliing not only fruit trees but shade trees and ornamental shrubs for a number of years. We are now handling these in large enough quantities to catalog.

We have at the head of our Nursery a thoroughly competent man, who is not only an expert fruit grower and well acquainted with fruit growing conditions in the central West but is also a graduate of the University of Nebraska.

Our fruit trees are all grown at home and adapted to this climate. We guarantee our trees to give you satisfaction in so far that if they are not satisfactory upon arrival you can return them immediately at our expense.

We catalog only such varieties as are productive and suitable for this climate.

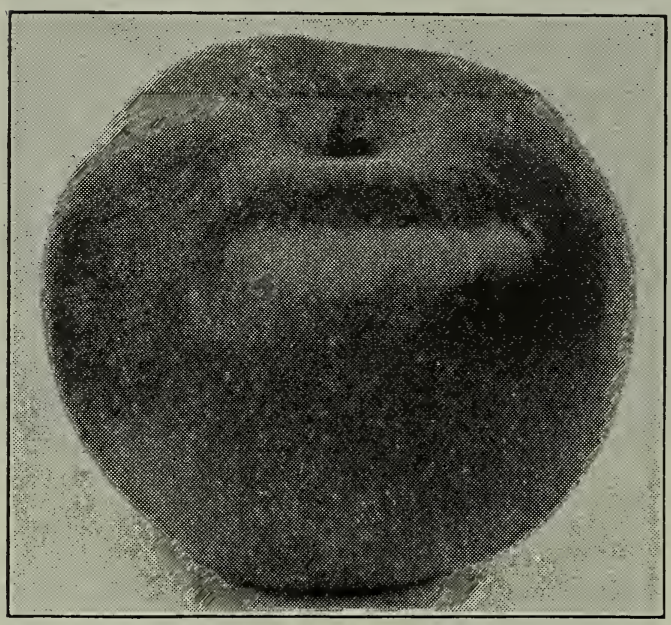

WEALTHY

JONATHAN. A delicious dessert apple. Fruit good size, surface smooth, clear, bright yellow almost covered with rich dark red on sunnyside; flesh white, tender, juicy and spicy. November to January.

WALBRIDGE. Medium size, striped with red, good cookconsidered of value in the North. December to January.

WEALTHY. One of the best known apples grown on account of its desirability. Fruit large, regular, smooth, bright yellow with crimson stripes and splashes, flesh white, often stained with red; very juicy. Sept. to Jan.

WINESAP. A valuable, well known variety. One of the leading export apples, fruit medium, roundish, skin moderately thick and very tough. Dark red with yellow; flesh very rich and firm. Season December to May.

\section{CRAB APPLES}

FLORENCE. A hardy tree, bearing young; fruit medium, of carmine color; flesh yellowish; medium fine; a fine jelly crab.

MARTIIA. A vigorous grower and free from blight. Fruit large jellow with heavy blush of light red, flesh fine grained, firm; very juicy and fine for cooking.

WHITNEY. (Hybrid.) (No. 20.) Fruit very large for a hybrid; yellow, striped red on sunny side; flesh yellow, very juicy; flavor rich and almost sweet.

\section{PEARS}

CLAPP'S FAVORITE. A large fine pear resembling the Bartlett but without its musky flavor. Pale lemon yellow with brown dots, very juicy with a delicate flavor.

GARBER. Large bright yellow with red; Juicy and good. splendid for canning. Trees not subject to blight and the fruit ripens just after the Bartlett.

SECKEL. Small. rich, yellowish brown. One of the best and highest flavored pears known. Very productive.

\section{APPLES}

OF OLDENBURG. Tree upright and tremely hardy. An early annual bearer of with red crops. Fruit large, greenish, yelplendid cooking favorite. Season July and August. mmer apple. Tree very hardy, bearing young llow when fully ripe; flesh white, very tender and of splendid quality. Tree is vigorous an annual bearer. Season July. th, round, beautifully flushed with red or good market sort. September and October. DAVIS. Fruit large, handsome, brightly triped with red; flesh medium quality. Very nd hardy. Season January to April.

GOLDEN. Tree vigorous. Fruit above dium, regular, surface rich golden yellow, sh yellow, flavor rich and spicy, slightly acid. pecially good for early winter. Season Nober to January.

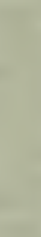

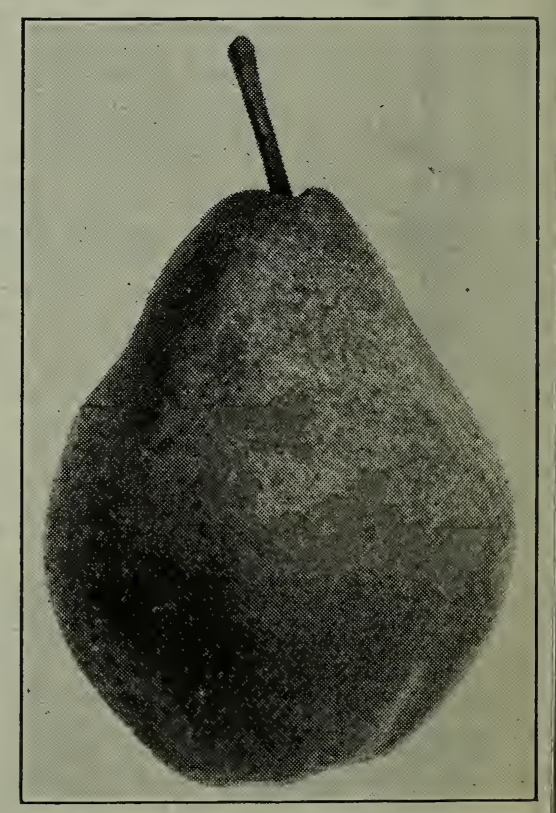

CLAPP'S FAVORITE 


\section{PEACHES}

ALEXANDER. (Cling.) Medium size, greenish white, nearly covered with rich red; flesh sweet and juicy. Tery productire.

HALE'S EARLY. (Semi-Cling.) Medium greenish white with red cheek; flesh white, melting, juicy. Abundant bearer.

TRIUMPH. (Free.) Medium round, somewhat flattened; greenish yellow, purplish red. Flesh yellow with red stains; juicy and rery good. One of the early sorts.

\section{PLUMS}

BURBANK. Medium to large, orange-yellow; dotted with red, flesh meaty, yellow, sweet and good; raluable for canning, hardy and rery prolific.

WOLF. Yellow, mottled with red; flesh yellow, firm and good quality. Very prolific bearer. Medium size.

WYANT. Medium large, oblong, purple, red on yellow ground; flesh firm and good quality; most popular sort.

HAWKEYE. Very large, dark red, rich and good. Tree a fine grower and hardy.

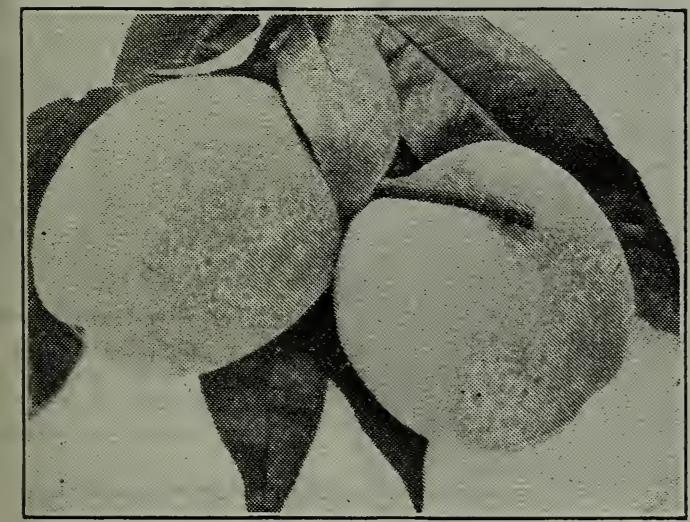

ALEXANDER

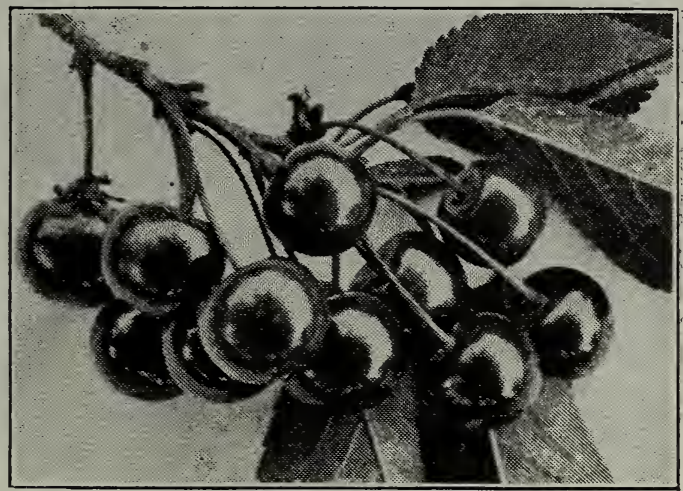

EARLY RICHMOND

\section{CHERRIES}

EARLY RICHMOND. Fruit dark red and of medium size, very juicy, acid flavor, one of the most ralued and popular varieties. Trees hardy and rery productive.

ENGLISH MORELLO. Medium to large, roundish, dark red, nearly black when ripe, flesh purrlish red, meaty, juicy. Very productire.

LARGE MONTMORENCY. Large roundish red, flesh tender. mildly acid and good quality. About ten days later than Early Richmond.

\begin{tabular}{|c|c|c|c|c|}
\hline 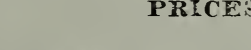 & $\begin{array}{l}\text { Aiz } \\
\text { Size }\end{array}$ & Per 1 & Per 10 & Per 100 \\
\hline & 5-6 & $\$ 0.30$ & $\$ 2.85$ & $\$ 27.00$ \\
\hline Apple & $5-6$ & .35 & 2.25 & \\
\hline ries …................. & -6 & .35 & 3.25 & 00 \\
\hline hes & -8 & .25 & 2.25 & 00 \\
\hline ............ & $5-$ & .35 & 3.25 & 00 \\
\hline ums & $5-\pi$ & .40 & 3.75 & 35.00 \\
\hline
\end{tabular}

By express at purchaser's expense.

SMALL FRUIT CULTURIST. By Andrew $s$. Fuller. The book corers the whole group of propagating small fruits, their culture, rarieties, packing for market, etc. It is very finely and thoroughly illustrated. 298 pages, $5 \times 7$ inches. Price, cloth, $\$ 1.00$.

THE PRACTICAL FRUIT GROWER. By S. T. Maynard. Just what the beginner needs and the successful fruit man practices. Illustrated. 128 pages. $5 \times 7$ inches. Price cloth 50c.
POPULAR FRUIT GROWING. By Samuel B. Green, Professor of Horticulture and Forestry in the Criiversity of Minnesota. A thoroughly practical work treating on the factors of successful fruit growing, orchard protection, insects injurious to fruits, diseases injurious to fruits, spraying apparatus, harresting and marketing, principles of plant growth, propogation of fruit plants, pome fruits, stone fruits, grapes, sman fruits, nuts, etc., etc. Profusely illustrated. 300 pages, $5 \times 7$ inches. Price, cloth $\$ 1.00$, postpaid.

AMATEUR GRUIT GROWING. By Samuel B. Green. A practical guide to the growing of fruit for home use and the market, written with special reference to a cold climate. Illustrated. $134 \mathrm{pp}$. Price, $12 \mathrm{mo}$. cloth, 50c; paper, 25 c.

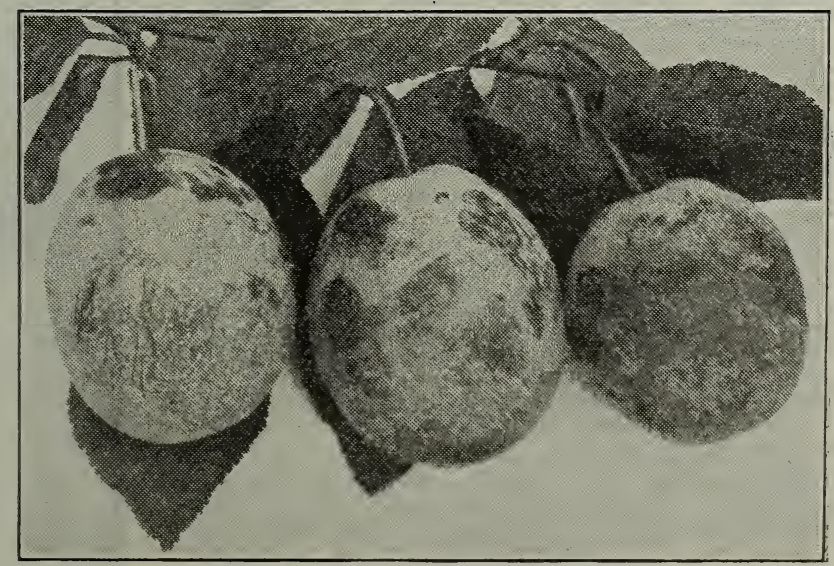

BURBANK 


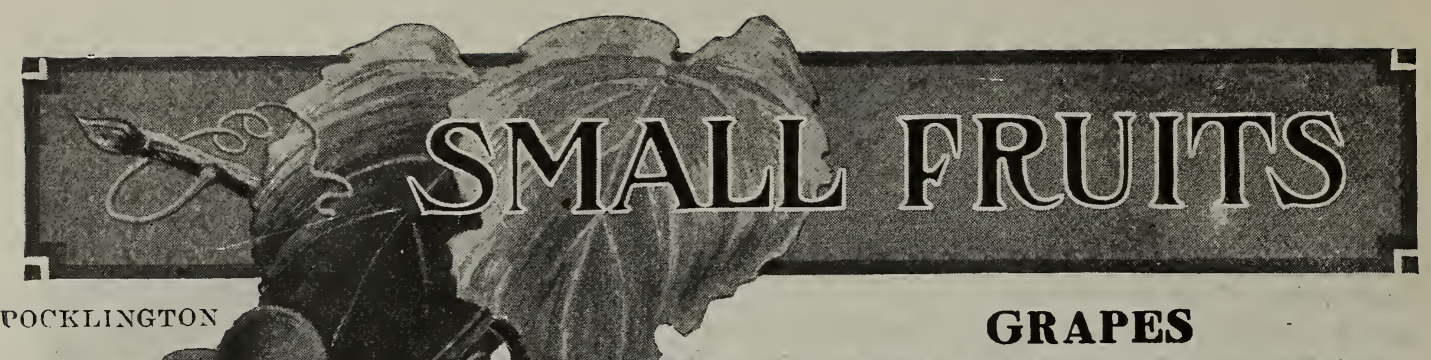

The Law is such that we cannot ship nurras stock into Wyoming.

There is scarcely a yard so small, either in country or city, that room for one to a dozen or more grapevines cannot be found. They do admirably trained up to the side of any building, or along the garden fences, occupying but little room and furnishing an abundance of the healthiest of fruit. Make the soil mellow, and plant the vines somewhat deeper than they stood in the nursery. Plant about 8 feet apart by the fence or building. For vineyards, make rows 8 feet apart, 6 to 10 feet in rows.

make rows 8 feet apart, 6 to 10 feet in rows.
Red.) Bunch large, compact, shouldered, berry AGAWAM. (Rinous and large, dark red or nearly black, good quality; later than Concord. $12 \mathrm{c}$, $\$ 5.00$ per 100.

postpaid. By express, 75c per doz.; $\$ 5.00$ per loo. shouldered; berries medium; skin thin; flesh tender, sweet, with scarcely any pulp; quality best. Vine a vigorous grower. bealthy, hardy and productive; one MOORE'S F.ART,Y

MOORE'S EARLY. (Black.) Bunch rarely s houldered, not quite as large as Con. cord; berries larger and ver much like it in flavor and quality. Vine a mod. erate grower, very $h$ e alth and hardy. Pro. duces $a$ f a i $r$ and, with high cuitivation cultivation,

heavy , ro Ripens so early as to be nearly out of market before concord is ripe, is, therefore, a very popular early market variety. Succeeds best on rich soil. $15 \mathrm{c}$ each: $\$ 1.25$ doz.; postpaid By express, 90c doz.; $\$ 6.00$ per 100.

NIAGARA. (White.) One of the leading white sorts; bunch large, shouldered, compact; berry large, yellowish white, juicy, vinous and sprightly, quality good; skin tough, making it a good shipper and market berry. $15 \mathrm{c}$ each; $\$ 1.25$ per doz.; postpaid. Ву express, 90c doz.; $\$ 6.00$ per 100.

POCKLINGTON. Pale green, usually with tinge of golden yellow where exposed to the sun; bunch large, very compact; berries very large, covered with a beautiful white bloom; flesh juicy, sweet, with considerable pulp. Vine a moderately good grower but very healthy and very hardy, its buds withstanding severe colr even better than Concord. It produces a heavy crop of fine showy clusters and on account of its fine appearance and many good qualities is yearly increasing in popularity $15 \mathrm{c}$ each, $\$ 1.25$ per doz.; postpaid. By express, 90c doz.; $\$ 6.00$ per 100.

WORDEN. (Black.) Bunch large, sometimes shouldered, compact; berries very large, skin thin. Superior to the Concord in the following points. It is better in quality, has a larger berry, a more compact and handsome cluster and ripens five to ten days earlier. It fully equals Concord in vigor and productiveness. $12 \mathrm{c}$ each, $\$ 1.00$ doz.; postpaid. By express, $75 \mathrm{c}$ doz.; $\$ 5.00$ per 100 . of the best early red Grapes. mens and do not always fertilize fully unless planted with Concord, Worden, Martha or other varieties which blossom at the same time. $15 \mathrm{c}$ each, $\$ 1.25$ doz.; postpaid. By express, $\$ 1.00$ doz.: $\$ 6.00$ per 100 .

CONCORD. The old, well-known and de servedly popular variety. Succeeds wherever grapes can be grown, $10 \mathrm{c}$ each, $\$ 1.00$ doz.: postpaid. By express, 75c per doz.; $\$ 3.75$ per 100 .

Insecticides and Sprayers, Pages $70-71$. 


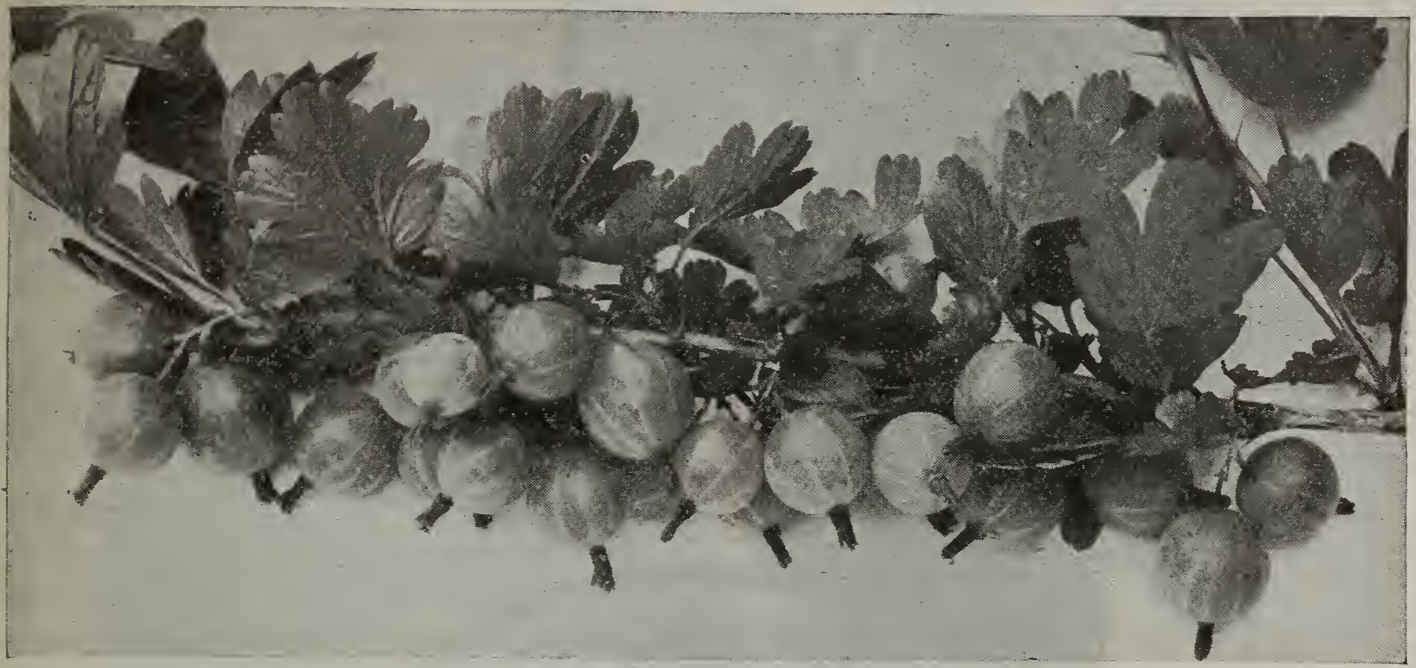

HOUGHTON GOOSEBERRIES

\section{GOOSEBERRIES}

The Laws are such that we cannot ship nursery stock into Wyoming.

Plant in good rich soil in rows 5 feet apart br 3 feet in the row, and give a liberal dressing of manure erery season. Regular pruning every year is essential for the production of fine fruit. The English rarieties especially do best in partial shade and should be heavily mulched. To prevent mildew spray bushes soon as leares appear and sereral times during the summer with potassium sulphide or Grape Dust (see page 70 ) one ounce to four gallons of water.

DowNING. An old and well-known rariety. Fruit large and handsome, pale green, of fine quality. A strong, vigorous grower seldom affected by mildew. One of the best. 20c each, postpaid. By express, $\$ 1.80$ per doz.

HOUGHTON. Fruit small to medium, pale red, of fine flavor. Plants of slender, spreading growth and enormously productive. 20c each. postpaid. By express, $\$ 1.10$ per dozen.

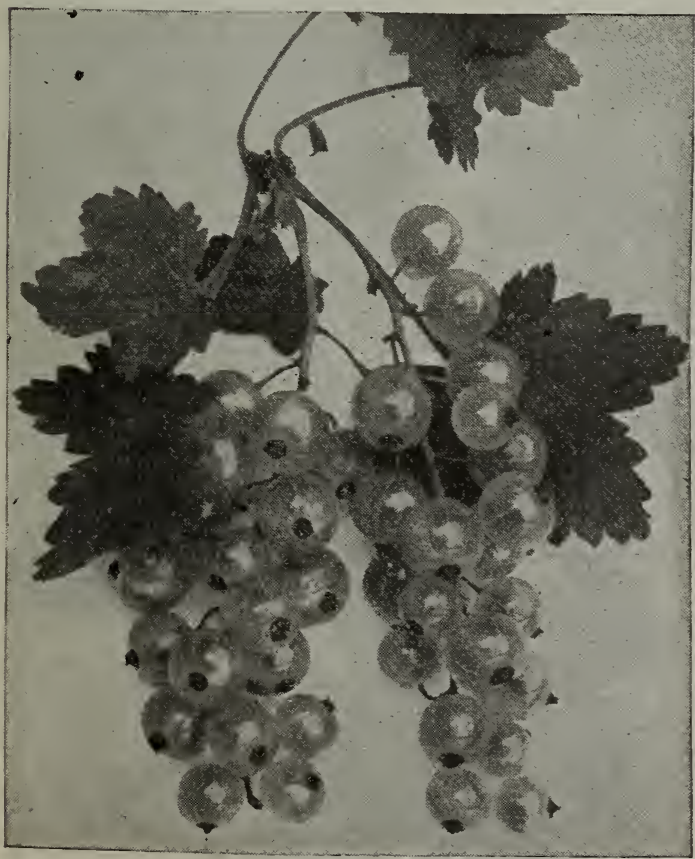

WHITE GRAPE CURRANTS

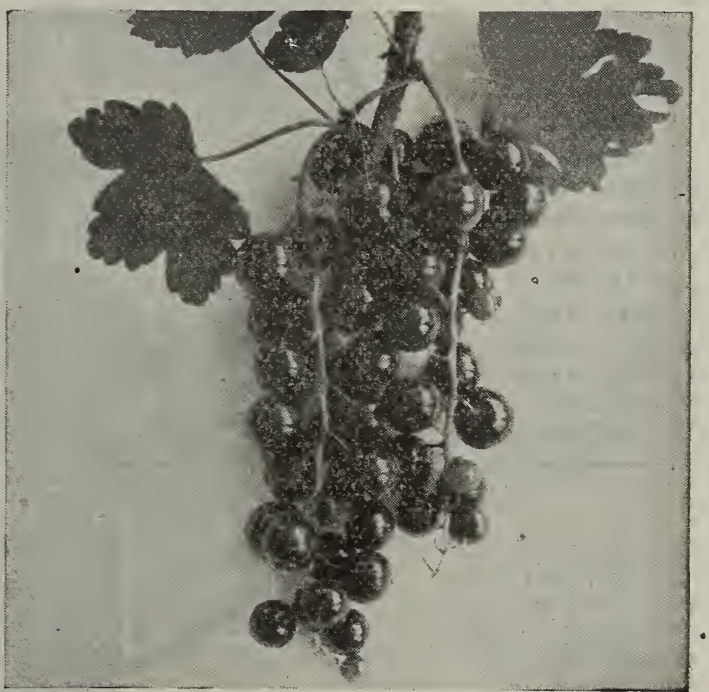

WILDER CURRANT

\section{CURRANTS}

Hardy, easily cultirated, stand neglect well, and liberally responds to cultivation and generous treatment; indispensable for jellies, etc. Set four feet apart in rich ground; cultivate well or mulch heavily; prune out ald wood so that each remaining shoot will have room to grow. If the currant worm appears dust with hellebore. All 2-year-old plants, well rooted and strong.

CHERRY. Berries sometimes more than half an inch in diameter, bunches short, vigorous and productive when grown on good soils and well cultivated.

FAY'S PROLIFIC. The leading market variety, bunches and berries large and uniform in size, easily picked; exceedingly productive.

VICTORIA. Large, bright red; berries medium size, of excellent quality. Erect grower, very productive. Ripens late, a valuable sort.

WHITE GRAPE. Very large, yellowish white, sweet or very mild acid. Excellent quality and valuable for the table. Productive.

WILDER. One of the strongest and most productive. Bunch and berries very larme, bright, attractive red color, even when dead ripe; hangs on bushes in fine condition for handling until very late. A valuable market sort.

PRICE

All currants $15 \mathrm{c}$ each; $\$ 1.25$ per doz.; postpald. By express, $\$ 1.00$ doz.; $\$ 6.00$ per 100 


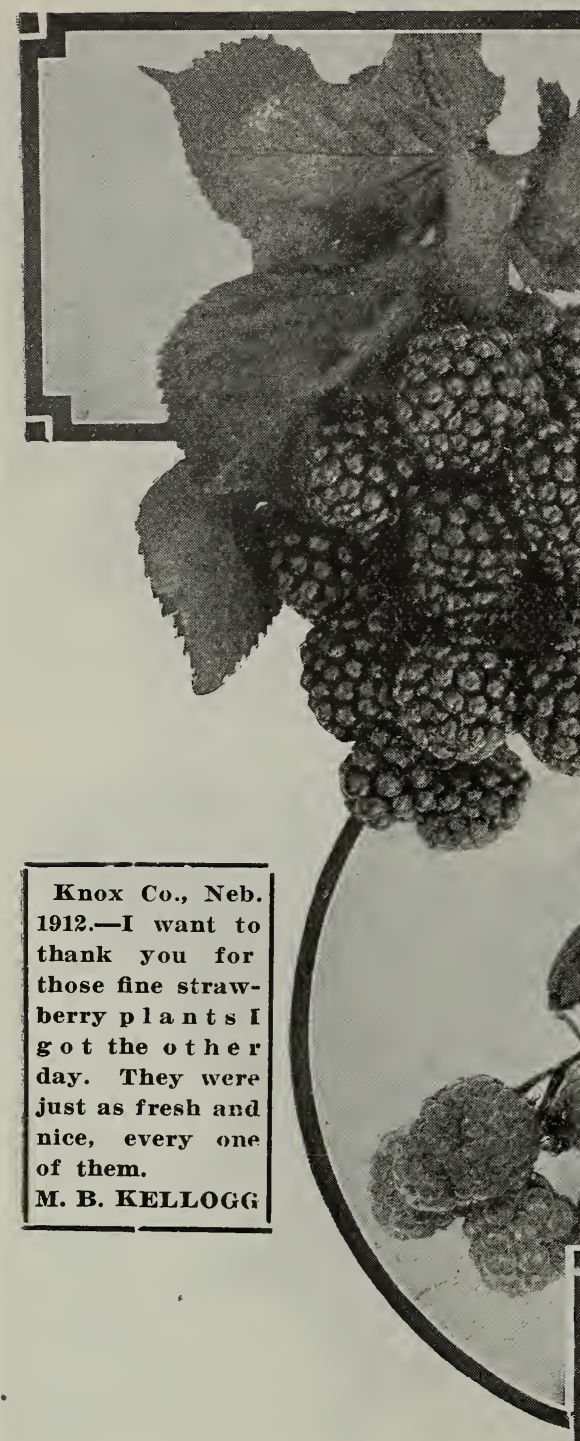

\section{Blackberries}

Blackberries are among the best. known and most valued of our berries. No fruit of any kind is more wholesome A liberal use of berries and other good fruit will save doctors' bills. Blackberries should be planted in rows six or seven feet apart, three to four feet in the row. Keep the ground light, rich and clean, and pinch the canes back when they have reached four feet in height. For garden culture set in rows 4 feet apart, light, rich soil being preferable.

BLOIVER. A splendid new sort. Has produced 2,694 berries on one bush, 2.270 quarts on $1-3$ acre. Large size, jet black, good shipper, best quality, unexcelled productiveness. 12c each; 6 for 6อ̆c; postpaid. By express, 60c per dozen; $\$ 3.75$ per 100 .

MERSEREAU. Berries large, jet black, very productive, sweet, good quality. Fine market sort. Price $10 \mathrm{c}$ encli; 90c per dozen; postpaid. By \$3.00 per 100 . SNYDER. Very popular
for the northwest on account of its ex. treme hardiness: wonderfully $\mathrm{p} \mathrm{r}$. ductire. size medium, fruit juicy and sweet, canes remarkably strong and thrifty. $10 \mathrm{c}$ each ; 80c per doz; postpaid. By exp ress, $45 \mathrm{c}$ pe $r$ doz.; $\$ 3.00$ per 100 .

\section{Raspberries}

Will do well on any soil that will produce a good corn crop. Land should be thoroughly prepared and well enriched; ground bone is one of the best fertilizers. Keep well cultivated and free from weeds and suckers. As soon as they are through bearing, cut out the old wood to give more vigor to the young canes. Plant 3 feet apart with 5 feet between rows.

CARDINAL. This wonderful berry surprises all by its great growth, extreme hardiness, exceeding productiveness and the unusual richness of its pure flavored, large purple berries. $12 \mathrm{c}$ each; $\$ 1.00$ per doz.; postpaid. By express, $75 \mathrm{c}$ doz.

CUMBERLAND. Largest black rasp: berry known. Perfectly hardy and vigorous grower. For productiveness nothing exceeds it. In quality rich, sweet and luscious; a mid-season variety. Each, 8c; 60c doz.; postpaid. By express, $45 \mathrm{c}$ doz.; $\$ 2.75$ per 100 .

KANSAS. Strong, vigorous, standing extremes of drought and cold, and bearing immense crops. E a rly berries, jet black and of best quality. 8c each; 60c per doz; postpaid. By express, 45c per doz. 


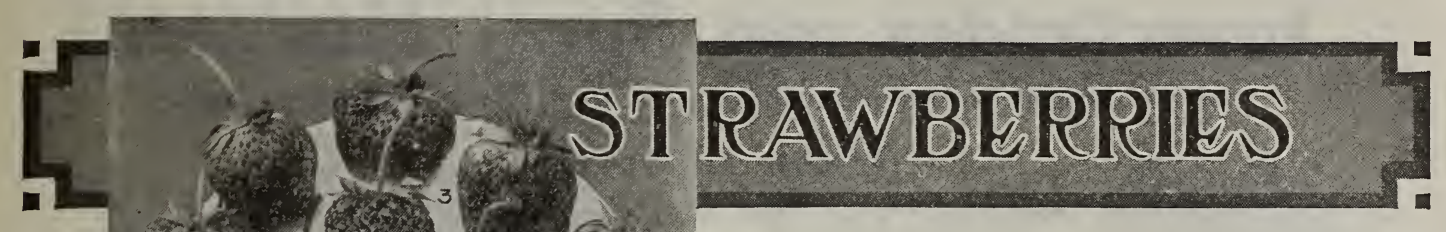

The laws are such that we cannot ship nursery stock into Wyoming.

CULTURE. On arrival of plants unpack them at once, loosen the bunches, "heel" them in the ground or dip their roots in a "puddle," made by mixing earth in water until of the consistency of cream, and lay away in a cool, damp place until they can be planted. Do not leave in package and pour water over them, as this will surely cause the plants to heat and spoil. To grow large berries and plenty of them, fertilizers must be used freely. Ground bone is excellent. Do not plant deep, but press the earth very firmly about the roots. Should the weather be warm, shade for a few days with coarse litter. Cultivate well and keep out the weeds. For field culture plant in rows four feet apart, with plants one foot apart in the row. For garden culture, plant three feet by one foot. Turn runners the direction of the row. When the ground freezes, mulch with light coat of straw. Remove the mulch in the spring and cultivate. (B) Perfect flowers-can be planted alone. (P) Pistillate, imperfect flowersmust have some marked (B) mixed with them, as close as one row in three.

BEDERWOOD. (B) (See No. 2 in cut.) ' This is generally considered to be one of the very best early varieties for home use or market. It is a splendid grower, making a large number of strong runners. It has a perfect blossom and is exceptionally productive. The fruit is of good size, light red, medium firmness and good quality. One of the best to plant with Warfield.

BRANDYWINE. (B) (See No. 3 in cut.) This variety has proven so satisfactory with all who have grown it that it is consequently in large demand. It is comparatively new and of great value by reason of its productiveness; large size, beauty and good quality, which renders it especially desirable for the home garden. The berries are a glossy crimson, very handsome, firm, solid and excellent in quality with a fine flavor. The plant is remarkably vigorous, hardy and exceedingly productive. It is a mid-season to late variety and is excellent to plant with Warfield. 35c per doz.; $\$ 1.35$ per 100 ; postpaid. By express, $\$ 1.00$ per $100 ; \$ 6.50$ per 1,000 .

EARLY OZARK. (B) Very early, producing large, well colored berries of excellent quality. Plants large and vigorous. This variety has been tested here for several seasons and proven very satisfactory. Excellent shipper. Price, 35̆c per doz.; $\$ 1.35$ per 100; postpaid. By express, $\$ 1.00$ per $100 ; \$ 6.50$ per 1,000 .

SENATOR DUNLAP. (B) (See No. 1 in cut.) Plant resembles Warfield, rampant runner, should be restricted in its production of plants; fully equal to Crescent and Warfield in its ability to succeed under all circumstances. Fruit good size, regular form, beautiful bright red, glossy, firm, splendid keeper and shipper, excellent quality, one of the best for canning; ripens early and continues a long time.

WARFIELD. (P) (See No. 4 in cut.) This variety stands next to the Senator Dunlap, being quite similar in shape and size. However, War. field is a sour berry and a little deeper in color, thus making it one of the very best for canning. It also holds its color in the cans, which is a very strong point in its favor. While the individual plants are quite small, it is remarkable the number of quarts produced by a lightly matted row grown on good strong soil.

Price of all except Brandywine and Ozark: Per dozen, 30c; $\$ 1.10$ per 100 , postpaid. By express, $75 \mathrm{c}$ per $100 ; \$ 5.00$ per 1,000 .

\section{something New Giant Himalaya Berry}

\section{PRICE}

Price. 12c each, 10 for $\$ 1.00$, postpaid. By express, 10c each: 10 for $75 \mathrm{c}$ : $\$ 6.00$ per 100 .

THE GIANT HIMALAYA BERRY. This berry is a recent introduction from the northern slope of the Himalaya Mountains, $6,0(4)$ feet above sea level. The vine is vigorous, very hardy and makes a growth of 20 to 30 feet in one year. It can be trained on a fence or arbor similar to grape vines. The berries are round and about three-quarters of an inch thick, very fine, with a tough skin and no core. They are jet black and very handsome. Like Blackberries, they are quite tart before they are fully ripe, but very sweet and rich when matured.
They are borne in enormous clusters of large sized berries, which ripen about Aug. 1st and bear until Oct. The first year there are a few blossoms, no fruit; the second year there is a medium crop; the third year and thereafter it yields a full crop. There has been practically no complaint from parties growing the Himalaya, but all praise it and say it's the finest berry every introduced. The Himalaya has no dead wood. It fruits from the old canes the same as new every year, but it is necessary to prune some wood away each year. 


\title{
Insecticides and Spray Mixtures
}

\author{
ALL OF THESE GOODS BY FREIGHT OR EXPRESS AT YOUR EXPENSE
}

\section{When to Spray}

Just before buds open. When fruit is set. Two weeks later. When fruit begins to color.

\section{Arsenate of Lead}

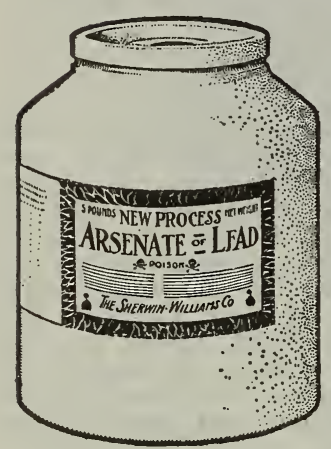

S. W. BRAND Arsenate of Lead is more sticky than any other insecticide, and is used where it is desirable that the poison should remain on the foilage. It positively will not burn. Use two pounds of Arsenate of Lead to 50 gallons of water. We sell only the best.

Price, $1 \mathrm{lb}$., 25c; $2 \mathrm{lbs}$., 4 ăc; 5 lbs., 80c; $10 \mathrm{lbs}$. $\$ 1.50$. Write for prices in larger lots.

\section{Lime-Sulphur Solution}

Use one gallon to make twelve gallons of liquid for strongest use or 24 gallons for summer spraying. For San Jose Scale spray every part of the trunk and branches after leaves are off in the fall and the tree is dormant, using one part to ten of water. Then again in the spring before the leaf buds open. Better make two sprayings of it if you can, about two weeks apart. Price, qt., $30 \mathrm{c}$; gal., $75 \mathrm{c} ; 5$ gal., $\$ 2.25$. Ask for price in larger lots.

\section{Target Scale Destroyer}

A remedy for San Jose Scale. This prepara. tion contains a combination of mineral and vegetable oils easily mixed with water. It does not clog the pump and nozzle. Dilute with 19 parts of water. Price, 1 qt. cans, 35c; $1 / 2$ gal. cans, $65 \mathrm{c}$.

\section{Tobacco Dust}

One of the best remedies for green and black aphis fleas, beetles, etc., also for insects in the ground. Lb., 10c; 5 lbs., 35c; $10 \mathrm{lbs}$., 50c; $50 \mathrm{lbs}$, $\$ 2.50 ; 100$ lbs., $\$ 4.50$.

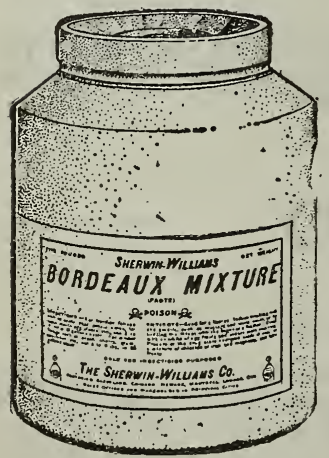

\section{Bordeaux}

\section{S. W. BRAND}

\section{Mixture}

In pulp, add 49 gallons of water to each gallon of Bordeau Mixture and spray all fruit trees before buds are open and again after the fruit has set. Potatoes will yield twice as much if sprayed with this mixture and Paris Green or Arsenate of Lead. Pt., 25c; qt., $40 \mathrm{c}$; 5 lbs. jars, $70 \mathrm{c}$ each; $25 \mathrm{lb}$. steel cans, $\$ 2.75$.

\section{Quick Bordeaux}

In making a Bordeaux Mixture some people prefer to have the lime and copper sulphate in a dry state. To supply this demand we furnish this Quick Bordeaux. $10 \mathrm{lb}$. bag, 4-6-50 formula (enough for 50 gallons mixture), price, $90 \mathrm{c}$ each.

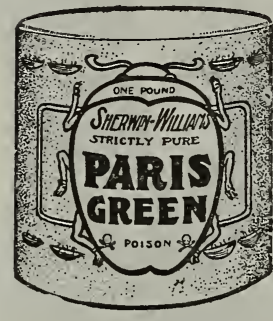

\section{Paris Green}

Paris Green is the most active poison known for the destruction of chewing insects, and it should not be applied or left where stock of any kind or children can have access to it.

For destroying the potato bug it should be applied in the proportion of one ounce of Paris Green to three gallons of water or 1 pound to 50 gallons of water. Price, by express, per $1 \mathbf{b}$., $30 \mathrm{c} ; 5$ lbs., $\$ 1.20 ; 14$ lbs., $\$ 3.25 ; 28$ lbs., $\$ 6.15 ; 100$ lb. lots, 20c per $1 \mathrm{~b}$.

\section{Kerosene Emulsion}

This is a safe and sure remedy to kill all sucking insects, that is those which get their nourishment through a proboscis, which they insert into the leaves or bark. Price, qt., 55c; gal., $\$ 1.10$.

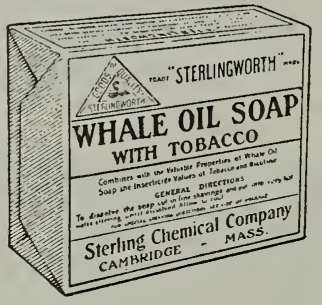

\section{Whale Oil Soap}

It effectually destroys the mealy buy and almost all lice on indoor and outdoor plants. Simply make a suds and spray the plants with it. Price, 1b., 20c; 5 lbs., 80c.

\section{Bug Death}

This is a powder used for $\mathrm{k}$ ill ing any bug or worm that eats the foliage or flowers of any plant. It is absolutely harmless to plant or animal life, thus making it a safe poison. Can be used dry or with water. For best satisfaction should be used wben the tender shoots first come. Price, $1 \mathrm{lb}$. pkg., 15c; 3 lb. pkg., 35c; Pat. Mar. 16 \& Nov. 9, 1897 5 lb. pkg., 50c; $121 / 2$ lb. pkg., $\$ 1.00$.

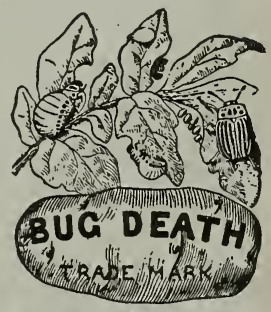

\section{Slug Shot}

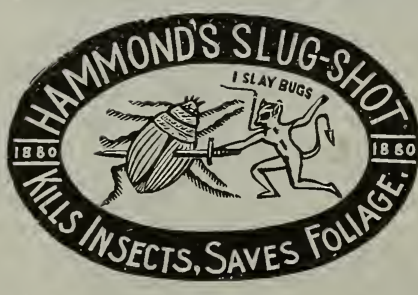

J u s t d u sted lightly on the plants. It kills potato bugs, cabbage worms, melons, squash and cucumber b u g s. Non-poisonous and harmless to a!1 creatures except in se ct life. By freight or express, $1 \mathrm{lb}$. can with perforated top, 15c; 5 lb. package, 40c; $10 \mathrm{lb}$. nackage, 75c. 


\section{GOPHERG0}

\section{(Machine Poisoned Raisins)}

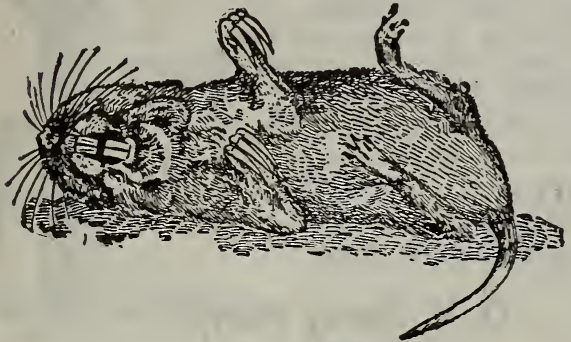

It will exterminate gophers, squirrels, prairie dogs, rabbits, and is the only prepared poison that will get a gopher. The gorernment advises poisoning as the most effective and best method of exterminating ground pests, but it must com- bine three points: an attractive bait, thoroughly poisoned, placed where they will get it. Gophergo does it. Try it, if it don't do the work we re. turn your money. Price, 1/2 lb., cans $25 \mathrm{c} ; 11 \frac{1}{2} \mathrm{lb}$. cans, 50c; $31 / 4$ lb. cans, $\$ 1.00 ; 91 / 2$ lb. cans, $\$ 2.50$.

S ULP H O - TOB SOAP. Is a powerful agent for the destruction of all bugs and insects. Of special value for spraying Roses, shrubs and rines. One or two applications will rid plants of the pests. Full directions with each cake.

3-oz. cake makes $11 / 2$ ga!lons, 10c; 14c, postpaid. 8-oz. cake makes 4 ga!lons, 20c; 29c postpaid.

$10-1 b$. cake makes $\$ 0$ gallons. By express, your expense, $\$ 3.00$.

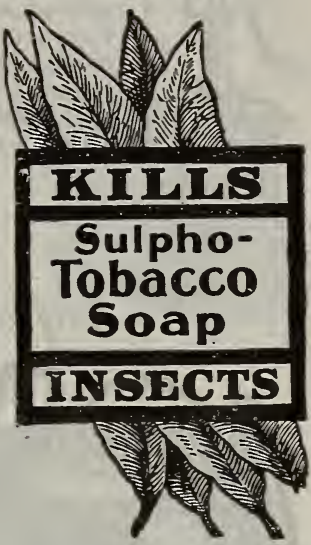

\section{SPRA YERS}
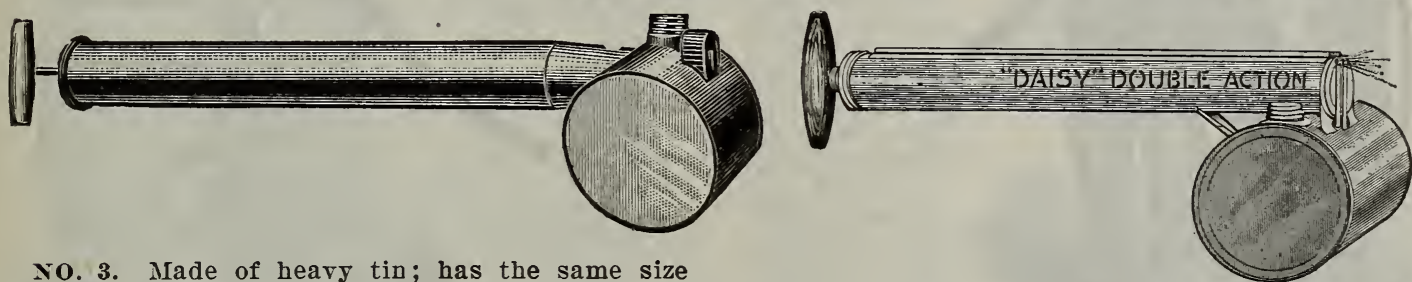

No. 3. Made of heary tin; has the same size air chambers as our other styles, and the reservoir holds about one quart, and throws a single spray straight ahead. Price, 50c.

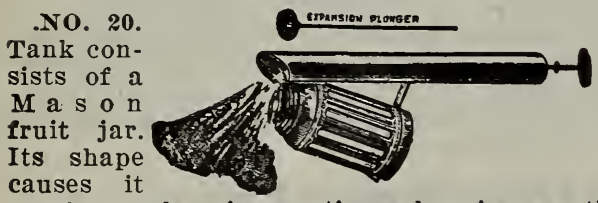

to give a churning motion when in use, thus keeping the ingredients thoroughly mixed. Price, 75̄c.

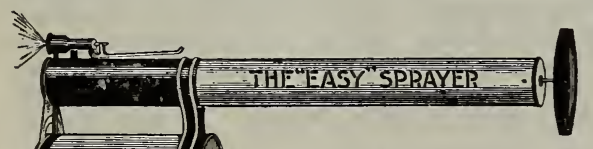

BRANT EASY SPRAY. ER. This sprayer holds one gallon of liquid, is equipped with automatic shut off lever nozzle, and made of heary galvanized iron. Just as good as the large sprayers only for size. Price, $\$ 1.00$.

THE

\section{ACRE-AN-HOUR} SIFTER

Acre-Antour Sifter PATENTED SEPT, 14. 1909

is ideal for applying BUG DEATH and other dry insecticides. Price, 75c.
THE DOUBLE DAISY. Sprays both ways. Push the plunger in and it sprays. Pull the plunger out and it sprays. Made out of galvan. ized iron and holds 1 qt. Does anything that any other sprayer will and does it twice as fast. Price only $\$ 1.00$.

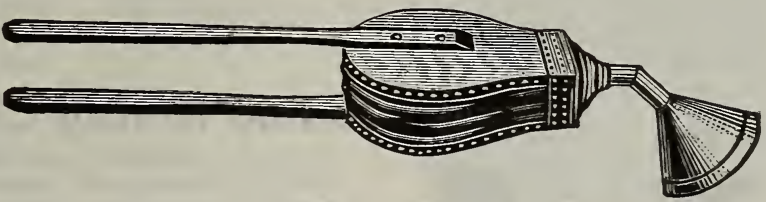

ACME POWDER GUY

Sprays any powdered insecticide. It weighs $11 / 2$ pounds. Price, $\$ 1.00$.

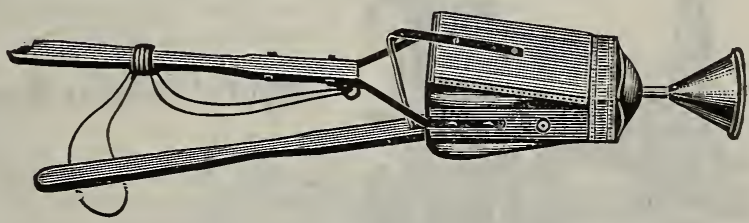

ACME DOUBLE POWDER GUN

Similar to the single but holds twice as much and rorks much faster.

Made out of the best material. Price, $\$ 1.50$.

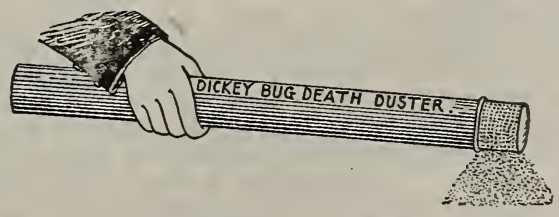

DICKEY DUSTER
For use in applying dry insect powder. Price, $25 \mathrm{c}$ each. 


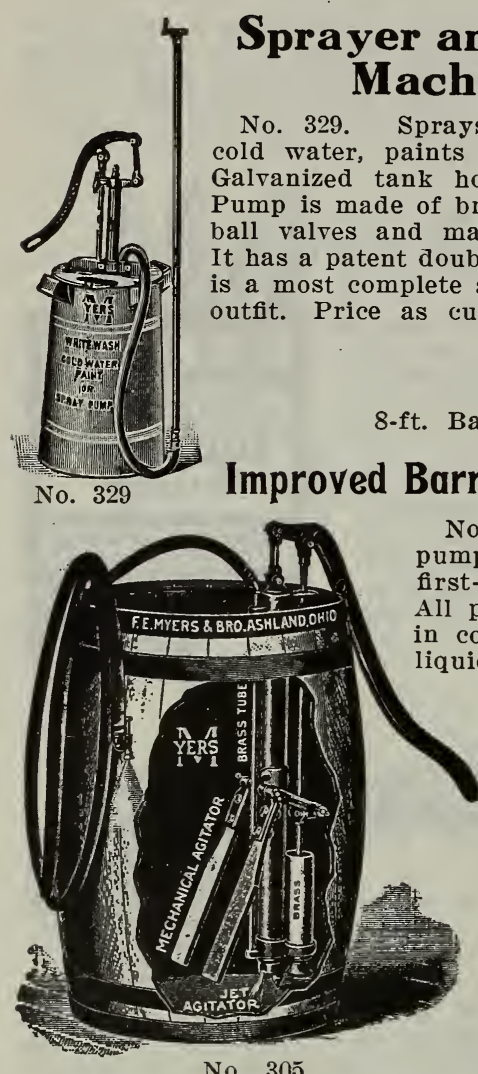

No. 305

\section{EXTENSION PIPES}

8-ft. Iron Exten sion Pipe, 45c

ft. Bamboo Extension Pipe, with cut-off, $\$ 3.00$

No. 27. A Brass Spray Pump, complete with agitator, hose, fine and coarse spray and solid stream nozzle, with malleable foot rest. Will throw a stream 50 feet. This is a first class all around sprayer, 28 inches high, made of $11 / 8$ inch brass tubing. Price, $\$ 2.50$.

\section{Little Giant}

Spray Pump

\section{O .K. Spray Pump}

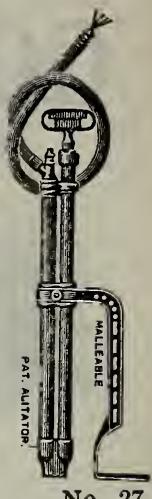

No. 305. Th i s pump is made in a first-class manner. il parts that come in contact with the liquid are of heavy brass. It can be easily and solidly bolted to any barrel. The air being com p r e s s e d into the air chamber with a 2-inch all brass cylinder $\mathrm{makes}$ the spray continu. o u s. A me. chanical agitator and small jet of liquid from the pump keeps the ingredients thoroughly agitated. It sprays whitewash, kalsomine, water, paints and any other liquid. Fitted with 15 feet of best 5-ply rubber hose, and graduated Vermorel nozzle complete as cut (except barrel). Price, $\$ 8.80$.

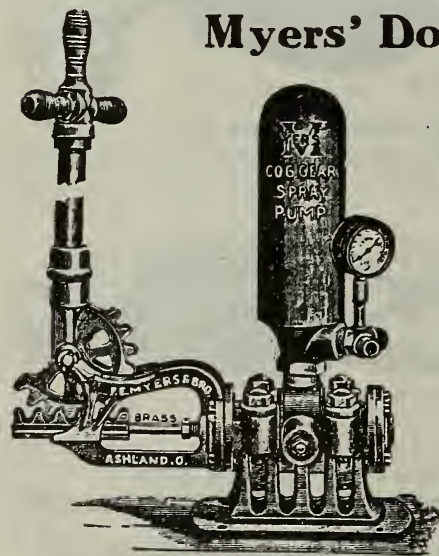

COG GEAR SPRAY PUMP
No. 307. For

\begin{abstract}
hot, cold or ans kind of mixture. $\mathrm{H}$ a s mechanical agitator, solid brass ram plunger, ground bevel valve and seat. $A$ strictly reliable first-class pump for sprayi $\mathrm{n} g$ orchar d s or $\mathrm{p}$ ot atoes. Easily a d justed to barrel of any size. The hand le is of wrought steel, so as to enable the operator to

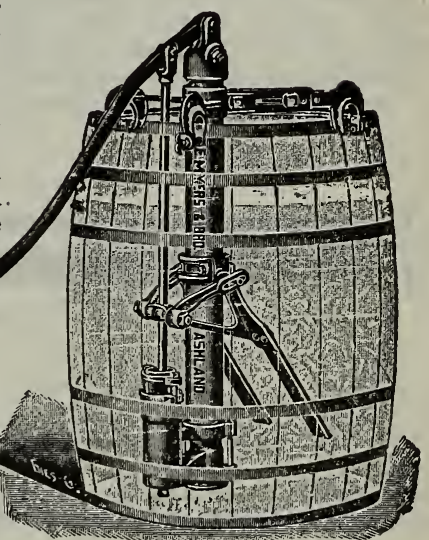

No. 307 O. K.

get up a pressure of $200 \mathrm{lbs}$. or more. It is fitted for 2 strings of discharge hose. Price without hose or nozzle, as cut (without barrel), $\$ 13.65$. Two 15-foot discharge hose and 2 graduated

nozzles, $\$ 6.35$ extra.
\end{abstract}

The air chamber is $8 \times 16$ inches. This insures a steady pressure when used with large power nozzles.

It is regularly equipped with belt pulley. If wanted with gear wheel give size of crank shaft on engine. Fitted with relief valve, pressure gauge, double cut-off discharge, 6 feet of wire-bound suction hose, two 8-foot pipe extensions and two power nozzles. No discharge hose. Price, \$53.00.

A SPECIAL PIPE to fit Nos. 27, 329, 305, 307 and for Meyers Knapsack, for spraying under leaves of Musk Melon or Cucum. ber vines, 50c each.

This is built especially for heavy spray work. The 2-inch cylinrod is brass. You with large air chamber, pressure gauge, 6-foot wire-bound suction hose, two 8-foot extension pipes, and two Vermorel or Bordeaux can be used on floor or barrel as the motion of handle hose for $\$ 5.00$ extra.

\section{Myers' Duplex Back Geared Double Acting Spray Pump}

No. 445. It is built strong for heavy pressure work. The $21 / 2$ inch heavy brass plungers inch stroke, in the verworking parts that come in con-

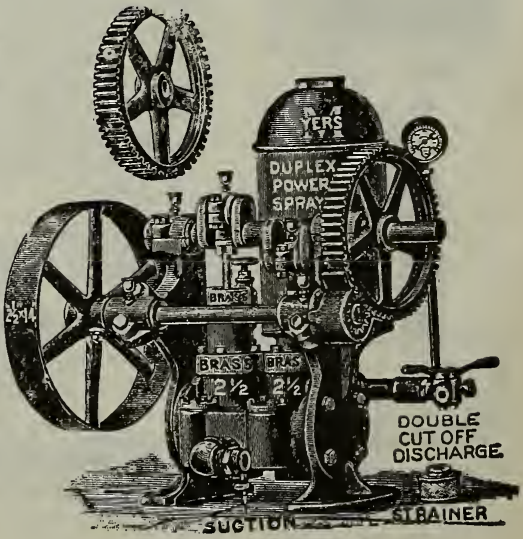




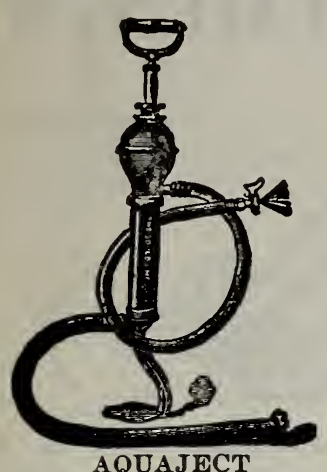

AQUAJECT

\section{Aquaject}

This pump will throw a stream about 60 feet. It can be adjusted to a rery fine or coarse spray. The crlinder, piston rod and couplings are all of brass. A good whitewash sprayer. Used with bucket, $\$ 5.00$.

\section{Myers' Knapsack Spray Pump}

The tank holds 5 gallons. The pump has a large air chamber. ball valves, solid plunger and agitator. It is so arranged that no water ran (lrip on the operator. The pump can be remored easily. The pump is also fitted with haudle, so the operator can set the knapsack on the ground and work as a bucket pump. The handle lever can be shifted from right to left shoulder at will. Price, $\$ \mathbf{5} .50$.

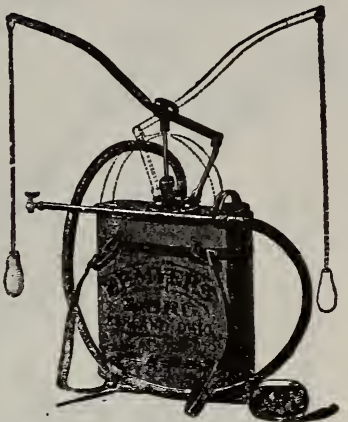

KNAPSACK

\section{Ideal Sprayer Outfit}

This is just the sprayer for small fruit, small orchard. and an ordinary size patch of potatoes. The tauk is made of galvanized iron and holds

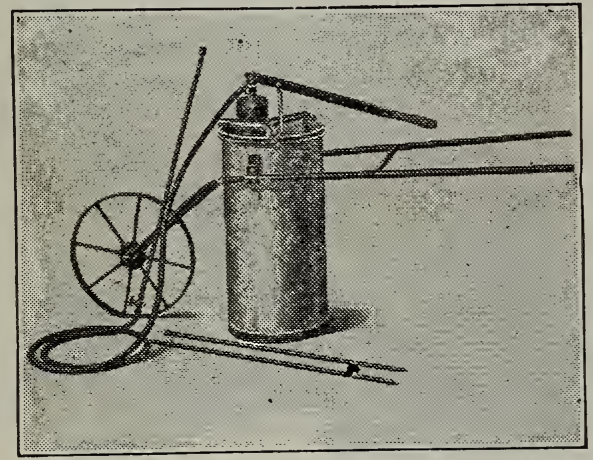

15 gallons. The extension pipe can be held and punp worked with one man.

The iron pump is equipped with a large air chamber which maintains the uniform pressure. It has a mechanical agitator and brass ball valves. It is complete with 10 feet $3 / 4$-inch pressure hose; 10 feet of extension pipe in 3 pieces; and a Brandt Ideal Nozzle. Price, $\$ 18.00$.

\section{Kant-Rlog Sprayer}

The s p r a er holds over 4 gallons.

The air pump is $\mathrm{made}$ of heavy brass two in ches in diameter. I safety ralre is provided.

Special attention is called to the new "KantKlog." The first and only nozzle ever made which gives both flat a $n$ d r o u n d sprays, or solid sprays.

A light pressure of the thumb starts the spray instautly. Remore it and the spray stops instautly. Price, Galvanized Steel and 3 feet brass

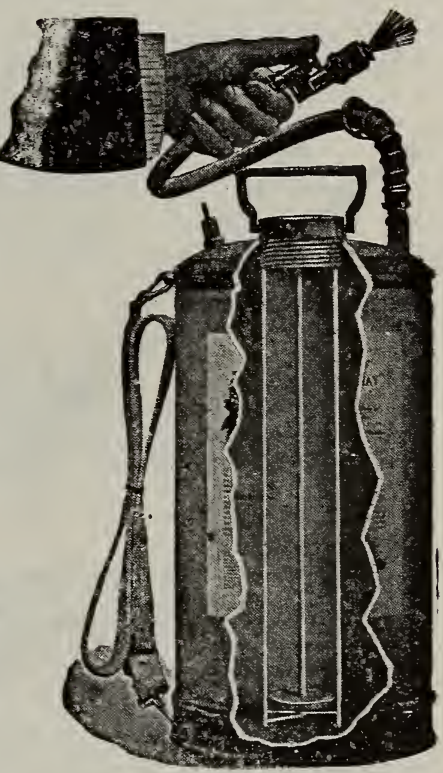
extension lorl. \$in.n0; Polished Brass and 3 feet brass extension rod, $\$ 6.50$.

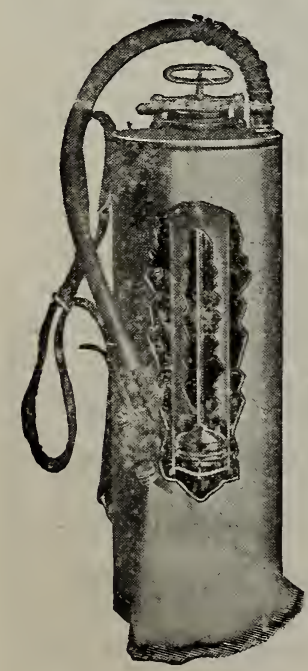

One Horse 4-Row Sprayer

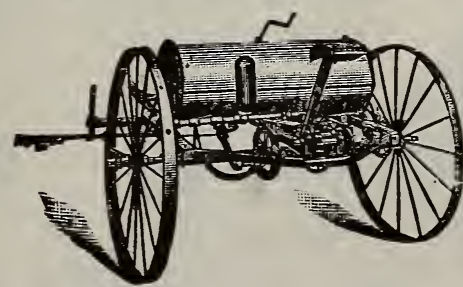

No. 100. Tank made of best g a l va n i zed ir o n, holds 55 gallons. T h e wheels turu an a i $r \quad p \quad u \quad p$ which furnishe s t h e co m. p res ed air. Best automatic horse sprajer we ever saw. Can be used for spraying orchards or potatoes. Isk for price and large catalng. aud l make a contiu slivis for nine minutes or If desired. will throw a sin. wlo stream 30 feet high. The reservoir holds 4 gallons. hut it should not be orer two-thircs full of solution ready for spraying. The cylinder is made of galranized iron and the pump strongly and rigidly made.

An automatic ralve called Auto Pop has been added and maclines equipped with this allow an instantaneous discharge, and the spray is in perfect control. We advise ordering with Auto Pop attachment.

Auto Sprayer, galvanized, \$4.50; with Auto Pop, \$5.40. Auto Sprayer Brass Tink \$6.75. Extension Rods, 2 feet lengths. 45c. 


\section{IRON AGE GARDEN IMPLEMENTS}

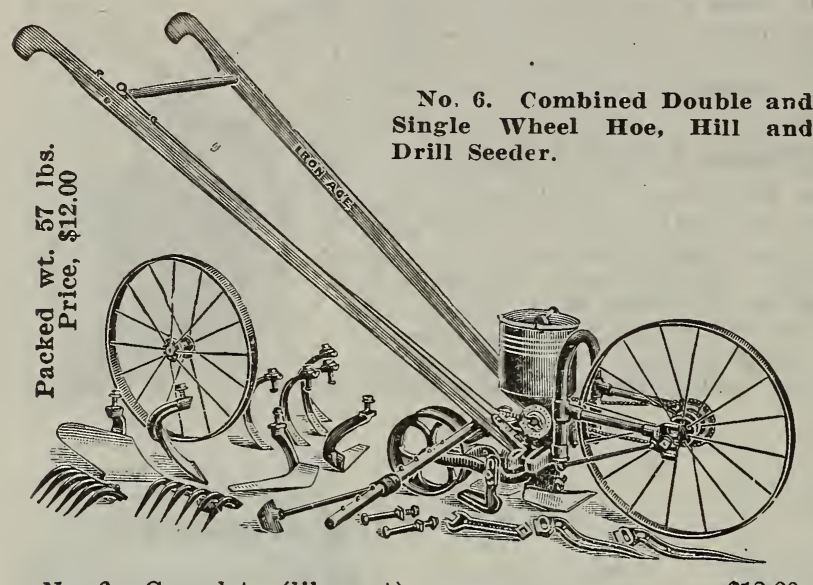

No. 6. Complete (like cut).

No. 7. As a Hill and Drill Seeder only

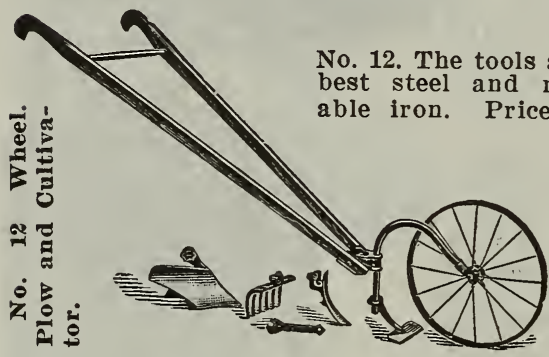

No. 19. Wheel Plow and Cultivator The wheel is made of steel, 24 inches high. and is very strong. The tire is 1 inch in width. The frame is made of steel throughout. The handles are made of best oak.

Price complete with

5 tools...................... $\$ 3.25$
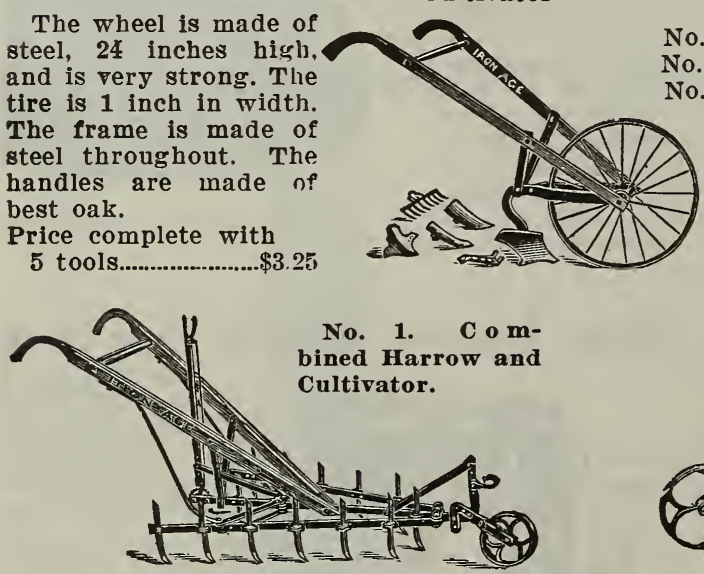

Price with lever expanded, as in $\$ 5.00$

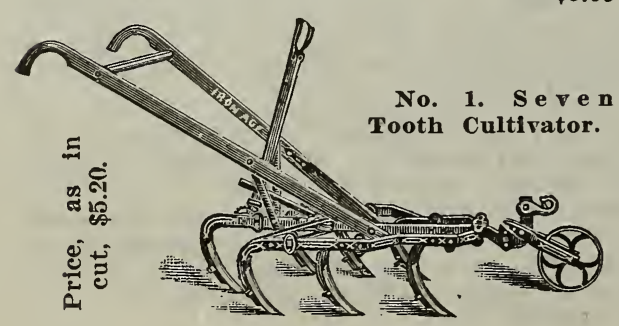

$\$ 12.00$

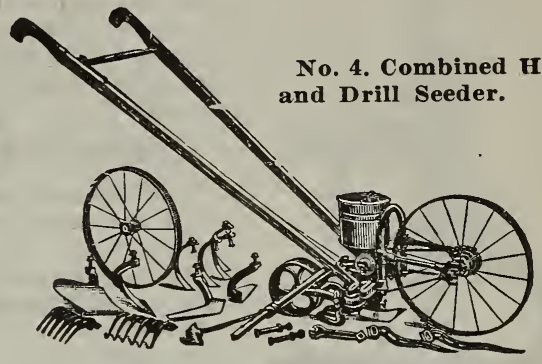

No. 4 same size and same tool as No.

6 , but does not drop in hills.... $\$ 11.00$ No. 5. As a drill only..................... 8.00

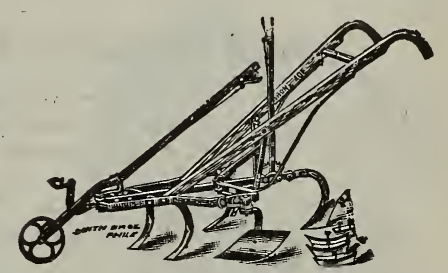

No. 6. Horse Hoe.

Complete (like cut) $\$ 6.25$

No. 1. Double and Single Wheel Hoe.

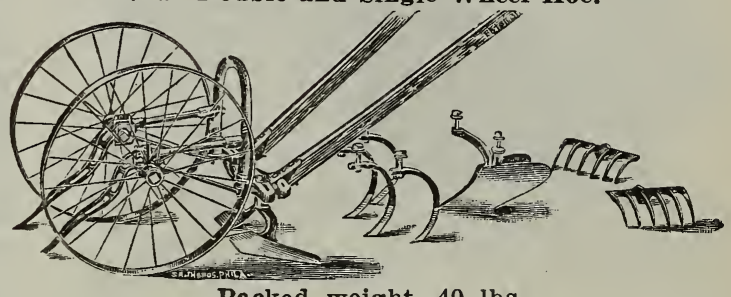

Packed weight, $40 \mathrm{lbs}$.

No. 1. Complete (like cut), 10 tools

No. 3. Side Hoes only, 2 tools..................................... 4.25

No. 13. Side hoes and Teeth, 6 tools..........................5.50
$\$ 3.90$

Steel frame and teeth.

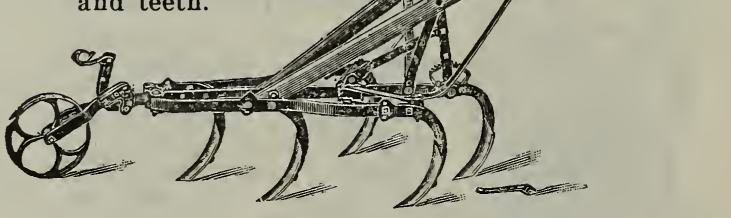

Ask for Special Iron Age Catalogues of $\mathrm{H}$ and Tools, Horse Tools, Sprayers, Potato Planters and Diggers. 


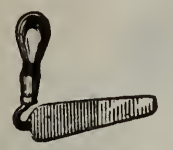

TRANSPLANTING TROWELS. Witn steel blade, $25 \mathrm{c}$.

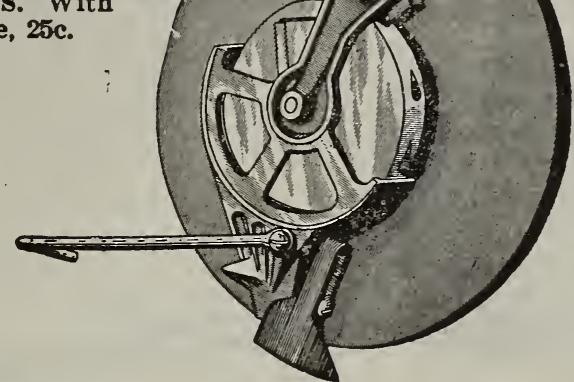

EUREKA SEED DRILL

It will sow and cover Beets, Cabbage, Carrots, Celery, Lettuce, Onions, Radishes, Spinach, Turnips, and all such seeds with the greatest regularity. Much better and faster than hand work. It is not a toy, but a strong, practical machine. Of course, when you hare a large garden you will want our Iron Age Drill, but for a few vegetables the Eureka is superb.

It is the only machine suited to sow in a hotbed. Sows the smallest packet of seeds as well as a large bulk. Price $80 \mathrm{c}$.

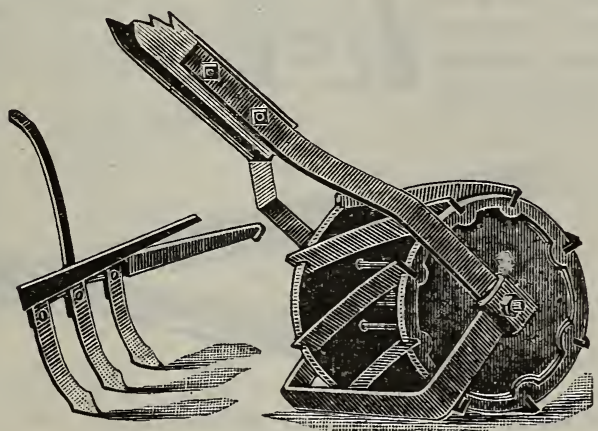

THE BARKER WEEDER AND MULCHER

It operates on the plan of a lawn mower. It is better than a hoe. It is ten times as fast. It is easy to operate. It forms a dust mulch. Cut your weeds in your garden once a week. With the revolving blades in your Barker the surface of the ground is chopped, the weeds are cut, separated from the soil and thereby destroyer.

It cuts the weeds under the ground as well as the weeds out of the ground. Price complete, with three cultivator teeth and leaf guards, $\$ 6.50$.

\section{The Cylone Seeder}

$\mathrm{S}$ i m p le in construction and easy of operation; has automatiic regulator and cut-off, and performs its work perfect $1 \mathrm{y}$. It is practical. Price,

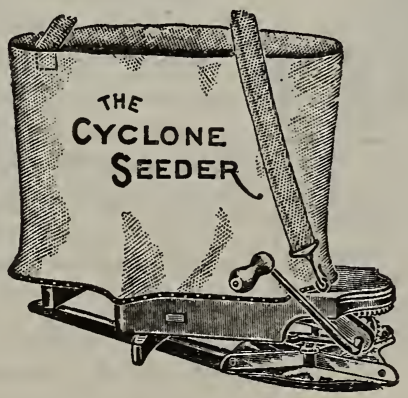

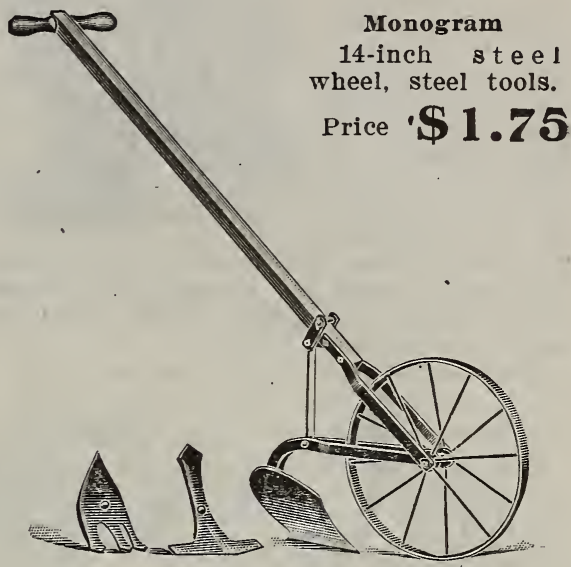

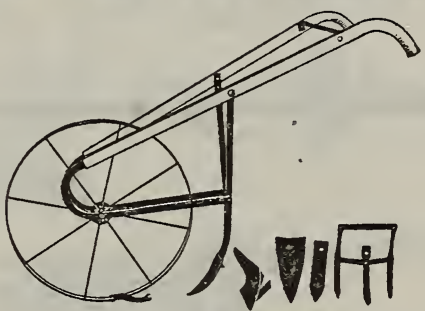

SUPERIOR NO. 2

In this plow the center of weight falls directly over the piroting point, making it selfbalancing. Height of wheel, 24 inches.

Price, with 5 steel tools as in cut .............................................\$2.

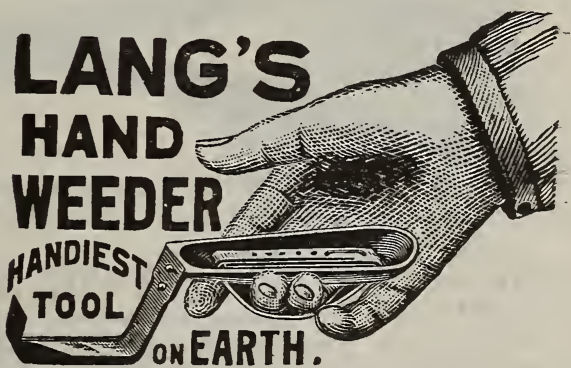

Weeder, 25c; postpaid 30c.

\section{Little Giant Seeder}

Will sow any. thing broadcast and do it right. Price, \$1.75.

\section{Cahuon Seeder}

The best machine of the kind in the market. The grain is held in a tight sheet-iron hopper surrounded by a bag which will hold a bushel of seed. Price, $\$ 3.25$.
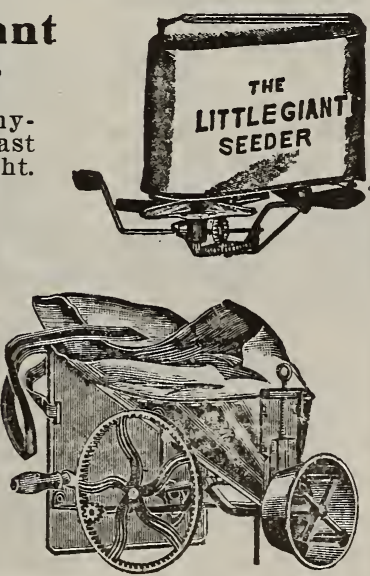


\section{NO. 1 CLIPPER} FANNING MILL. This is the suall size of the fanning mill and seed separator used by all seedsmen. It will se parate small seed from large, $\mathrm{ta} \mathrm{ke} \mathrm{out}$ light seed, straw and weeds all at one time. Is equipped with ten screens, will fan all kinds of grain and seed. Send for large catalog of fanning mills.

Price, complete.

$\$ 21.00$

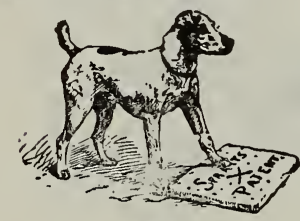

DOG CAKES. An especially prepared food for dogs, cats. rabbits, etc. Price, $25 c$.

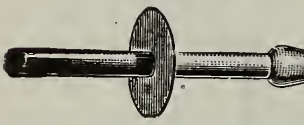

LITTLE GIANT MOLE TRAP

Most simple and best trap on the market. Fully guaranteed to give sntIsfaction. Price, toc each.

\section{GIANT TIN HORN SEEDER}

$\Lambda$ light, accurate seeder that will broadcast clean seed from 30 to 40 feet. Price 75c.

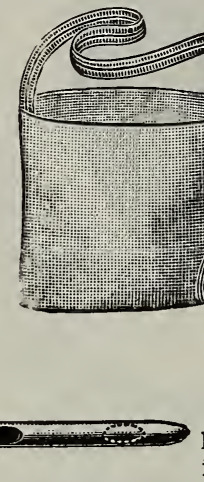

NICKEL PLA'TED MILKING TUBES Use for sore and obstructed teats and hard milking cows: 2 inch, 2 为 inch, 3 inch long. Price, 25c each, postpaid.

\section{PRUNERS AND SHEARS}

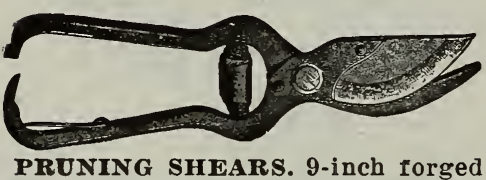

steel, polished blades, volute spring. $65 c$.

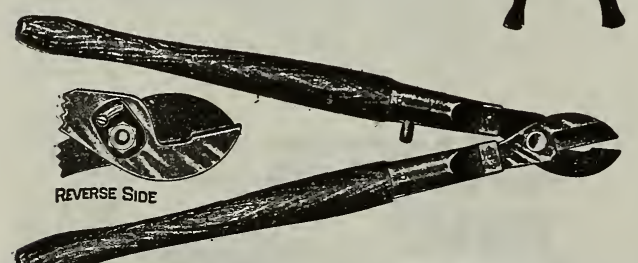

NO. 136 PRUNER. The best grade of forged steel. Handles 22 inches long. Price $\$ 2.00$.
TREE PRUNERS. HEDGE SHEARS. $\Rightarrow$ waters' cast steel Cast steel, notched, burnished handles. 8-inch $\$ 1.35 ; 9$-inch. $\$ 1.60$; 10-inch, $\$ 1.90$. $\$ 1.00$.

\section{THE MUK SUB-} STITUTE.

Blatchford's Calf Meal is for calves what Mellin's Food is for babies. Raises the finest calves at about half the cost of milk. Prevents scouring.

$100 \mathrm{lb}$. bag (makes 100 gallons of rich, nutritious $\mathrm{g} \mathbf{r}$ u e l), $\$ 3.50 ; 50$ lb. bag, $\$ 2.00 ; 25$ lb. bag. $\$ 1.10$. Try it and sell the milk.
FOR STOCK

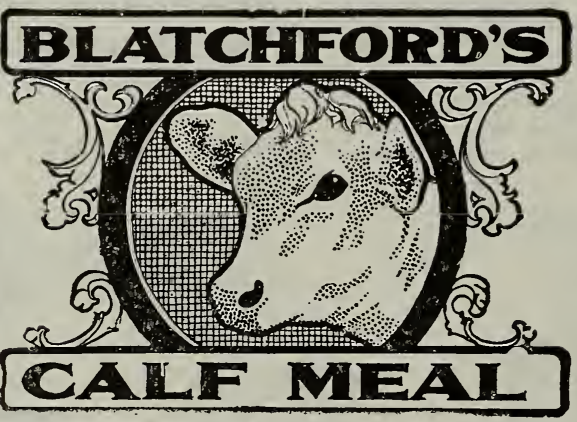

\section{CALF DEHORNER}

This comes in the shape of a pencil, and is very easily applied. Clip off the hair around the little horn at the time it feels like a button and before it starts througn the skin. Dampen it a little with water, and rub it with the Dehorner material. This causes the horn to stop growing, and should be applied when the calf is from 5 to 10 days old. (Enough for 25 or 30 calves.) Price 50c, postpaid.
NO. 9 PRUNER. A good grade of steel, with polished blades. Price $\$ 1.00$.

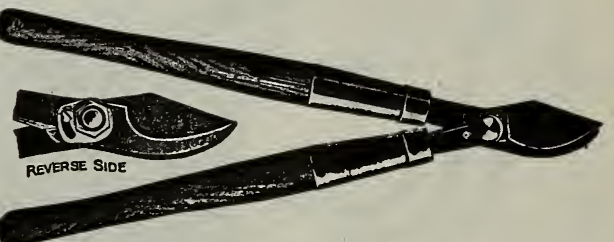




\section{POULTRY SUPPLIES}

ALFALFA MEAL. Made from green, kiln-drieá alfalfa hay and is 2 to 3 times more valuable than clorer meal. Good for chickens or stock. 12 lbs., 25c; 50 lbs., 80c; 100 lbs., \$1.40.

ALFALMO MEAL. Same as alfalfa meal except that it is mixed with syrup, a decided addition. 12 lbs., 25c; 50 lbs., 80c; 100 lbs., \$1.40.

BLOOD MEAL. This is pure, rich, dried blood. Very fine for incubator chicks, as it prevents loss from breaking down or leg weakness. Good to start hens laying. Feed one part blood meal to fleen parts of mash. 6 lbs., 25c; 50 lbs., $\$ 2.00 ; 100$ lbs.. \$3.75.

BEEF SCRAPS. For laying hens may be mixed one part meat scraps to three parts crushed grain, bran or shorts. Wet with hot water, or skimmed milk preferred. Feed night and morning. 7 lbs., 25c;

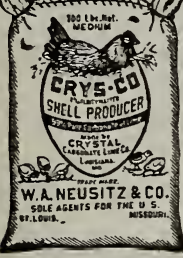

CRYS-CO. A shell producer and grit in one. It is the crystallized molluscan shell formation or petrifled shell, nature's own product, and is mined and crushed coarse, medium and fine for the great American hen. 17 1bs., 25c; 50 lbs., 50c; 100 lbs., 85c.

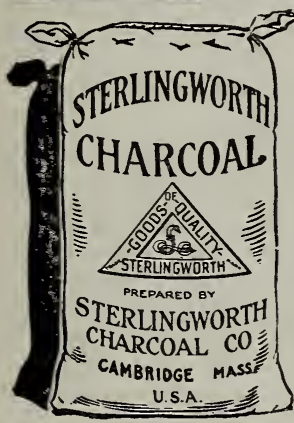

CHARCOAL. This is a most excellent ingredient to mix with mash. $5 c$ per lb., 6 lbs. for 25c. CRUSHED SHELLS. It you expect your hens to lay eggs you must furnish them with something to make shell. 17 lbs., 25c; 50 lbs., 50c; Clam Shells, 75c per 100 lbs.; Oyster Shells, 85c per $100 \mathrm{lbs}$.

CRYSTAL GRIT. Not only your large fowls,

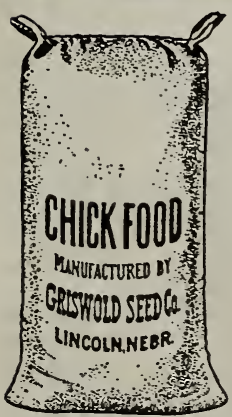

but your small chickens must have grit. Most so-called chicken cholera is simply in. digestion caused by lack of grit with which to grind the food. Large, medium and chick. 17 lbs., 25c; 50 lbs.. 50c; 100 lbs., 85c.

GRISWOLD'S CHICK FOOD. This consists of millet, whent and other seeds, grit, bone, etc., in such proportions as shall supply the young grow. ing chickens with all that is necessary to secure healta, vigor and growth. It not only is a money maker but saves much time In feeding. 8 lbs., 25c; 50 lbs., \$1.35; 100 lbs., $\$ 2.60$.

SCRATCH FOOD. From 15 to 20 kinds of seeds and grains; specially good for grown fowls. Do not confuse this with screenings. This has no waste whatever, no grit. $15 \mathrm{lbs}$., 25c; $50 \mathrm{lbs}$., $80 c ; 100$ lbs., $\$ 1.50$.

TOBACCO DUST. Sprinkle it around the chicken house and nest. It keeps away the lice. Per lb., 10c; 5 lbs., 35c; 10 lbs., 50c; 100 lbs., \$4.00.
POULTRY BONE should be kept before poultry of all classes, at all times, especially where egg production is desired. They will be the best judges as to the amount they want. Young chickens should be permitted to get it at their pleasure. Large, medium, chick and meal. 8 lbs., 25c; 50 lbs., \$1.35; 100 lbs., \$2.65.

SULPHUR. 10c per lb.; 3 lbs., 25c. Ask for prices in large lots.

\section{NO. 32 HAND GRINDING MLL}

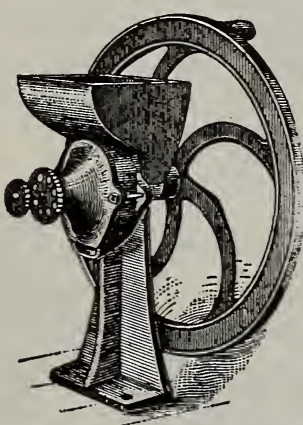

In this mill are em. bodied all the good features of other hand grinding mills to which have b e e n a d d e d universal burrs or grinding plates that are adjustable for grinding coarse or ine. This machine grinds oats, barley, rye, corn, peas, dry bone, shells, etc., for feeding to poultry. It is a well designed machine, is strong and well made throughout and of excellent finish, has a 16-inch fiy wheel and is light running.

The capacity of this mill is not equalled by any other of the same size. Shipping weight $40 \mathrm{lbs}$. Capacity, 1 to 2 bushels per hour. Price..........\$4.00 MODEL MILL. Capacity, $1 / 2$ to 1 bushel. Sim.

ilar, but not so good as above. Price............\$2.50

\section{STEARNS' BONE CUTTER}

It has a u $\mathrm{tomat}$ ic feed; is self-cleaning; is the fastest fine cut. ting machine on the market; will stand more wear and tear; is least liable to get out of order; is the only Bone Cutter that will not clog with gristle or meat.

Price $\$ 9.00$
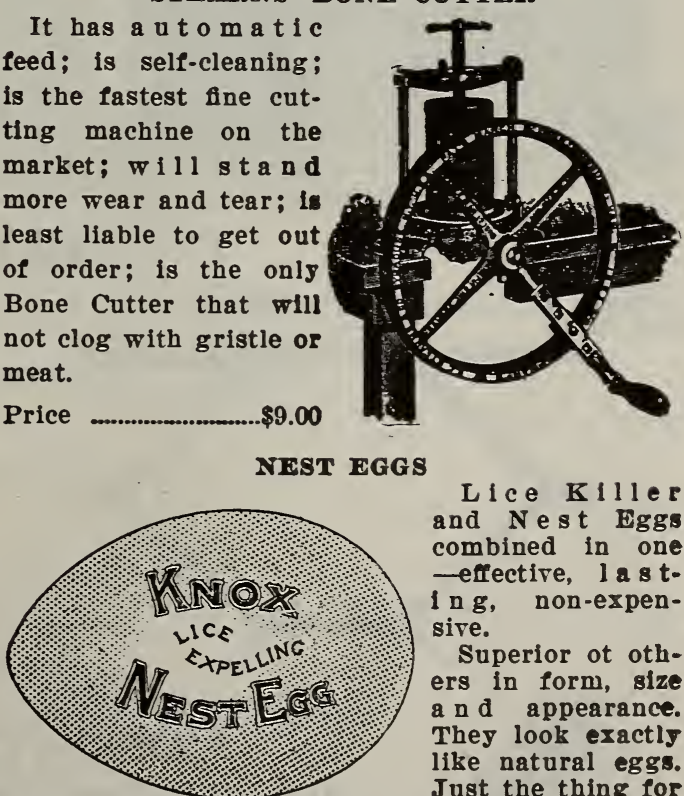

Lice K111er and Nest Eggs combined in one -effective, 1 a 8 t. ing, non-expensive.

Superior ot others in form, size a $\mathrm{nd}$ appearance. They look exactly like natural eggs. Just the thing for laying hens. 5c each; 6 for 25c; 13 for 50c; 6 for $45 \mathrm{c}$; postpaid.

\section{PORCELAIN NEST EGGS}

Made of Flint Glass. 2 for 5c; 25c dozen; 6 for 25c; postpaid.

POULTRY MANUAL. By Franklane L. Sewell and Ida F. Tilson. A safe guide to successful poultry culture in all its branches, fancy and practical breeding and feeding; diseases and remedies, how to make farm poultry pay, etc. 12 mo. $148 \mathrm{pp}$. Price, paper, 25c. $40 t \mathrm{th}$ thousand.) 


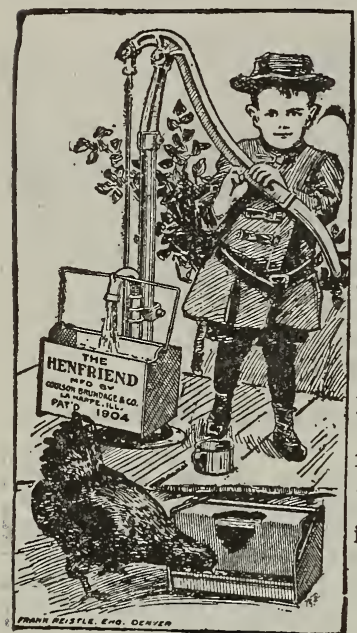

HENFRIEND

Made of very best

g a l v a n ized iron,

cheap, practical and

durable, protected

from dirt, yet easy

to clean; will not

drown the chicks;

easy to fill and car-

ry as a pail. Keeps

the water cool in

summer. Filled with

hot water in the morning will not freeze during the day in cold weather. A child can fill it. $2 \frac{1}{2}$ gallon size 60c; 1 gallon size $45 c$; $1 / 2$ gallon size, for little chickens,

LEADER ADJU STABLE LEG BAND

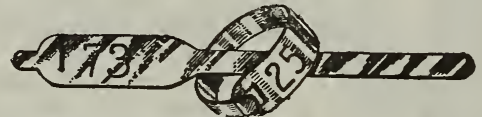

Dozen 15c; 25 for $25 \mathrm{c} ; 50$ for $40 \mathrm{c}$; 100 for $65 \mathrm{c}$; postpald.

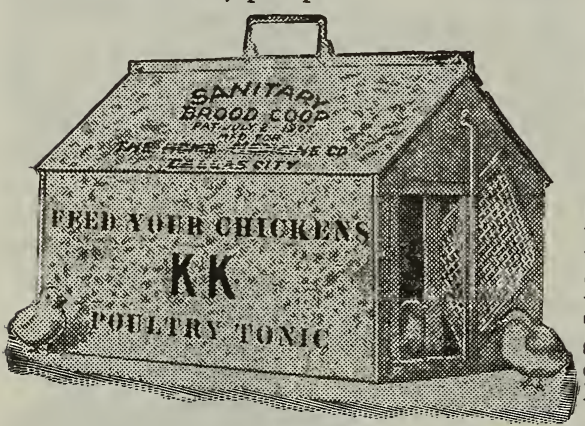

\section{POULTRY NETTING}

Heary galvanized poultry netting in 1 and 2 Inch mesh.

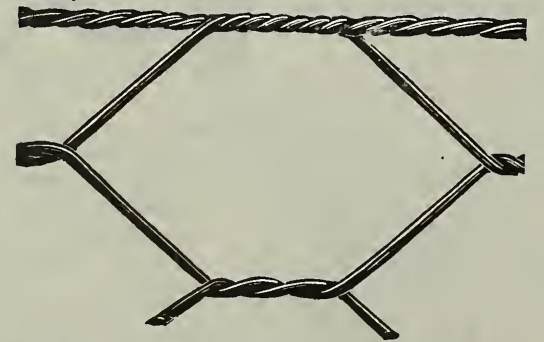

\begin{tabular}{ll}
\multicolumn{2}{|c}{ Width } \\
12 inches \\
18 inches \\
24 inches \\
30 inches \\
36 inches \\
48 inches \\
12 inches \\
18 inches \\
24 inches \\
30 & inches \\
36 & inches \\
48 & inches \\
72 & inches
\end{tabular}

Jar, leaving pan without any obstruction, affording eas cleaning. Thus a sanitarj fountain. Made to flt any half gallon, quart or pint Mason far. We do not furnish jars. Price 15c each, 2 for $25 \mathrm{c} ; \$ 1.25$ per dozen.

\section{SANITARY BROOD COOP}

Made of galvanized iron, it is mite, rat, weasel, mink and skunk proof. It can be taken down and put up in 40 seconds. The bottom can be removed for cleaning without taking coop aaprt. It has three doors hung on one pivot: the first a slat door which lets the chicks out; the second, of one-half inch wire netting, for use on hot nights; the third door is of solid iron for cold and stormy weather. The coop is well ventilated but is entirely rainproof. It is approximately 18x24 inches square and 16 inches high. It

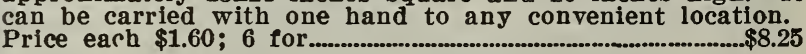

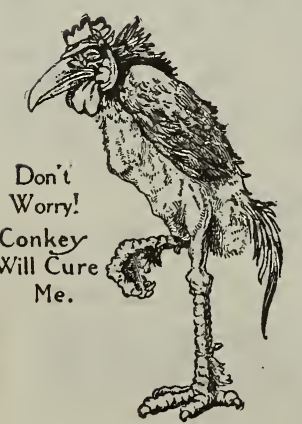

CONKEY'S
One Inch Mesh $150 \mathrm{ft}$. long per sq. ft. Per roll Less than roll $\$ 1.68 \quad 11 / 2$ cents $\begin{array}{ll}1.68 & 11 / 2 \text { cents } \\ 2.52 & 11 / 2 \text { cents }\end{array}$ $\mathbf{2 . 5 2} 11 / 2$ cents $4.35 \quad 11 / 2$ cents $5.00 \quad 11 / 2$ cents 6.68 $11 \%$ cents Two Inch Mesh $\begin{array}{ll}.75 & 3 / 4 \text { cent } \\ 1.10 & 3 / 4 \text { cent }\end{array}$ 1.40 3/4 cent 1.40 1.75 2.05 2.80
4.25 $3 / 4$ cent $3 / 4$ cent $\begin{array}{ll}3 / 4 & \text { cent } \\ 3 / 4 & \text { cent }\end{array}$
Weight per roll 15 pounds 23 pounds 30 pounds 38 pounds 45 pounds 60 pounds

10 pounds 15 pounds 20 pounds 25 pounds 30 pounds 40 pounds 60 pounds

\section{ES}

EACH ARTICLE MUST SATISFY OR YOU RECEIVE YOUR MONEY BACK Send 4c to pay Postage, and get Big 50c Remedy Book FREE!

Roup Cure... Collect

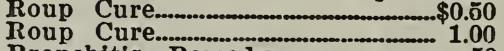
Bronchitis Remed

White Diarrhoea Remedy...............50

Cholera Remedy

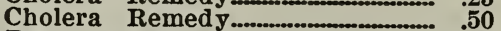

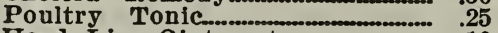

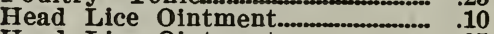

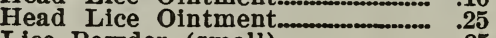

Lice Powder (small) $\ldots$

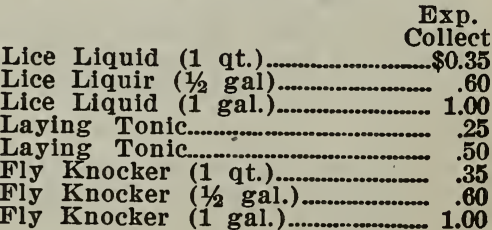

Co.35

Lice Liquir $(1 / 2$ gal)............................

Laying Tonic galla

Fly Knocker (1 q t.) ...........................

Fly Knocker (1/2 gal.) .............................. 1.00 


\section{Incubators}

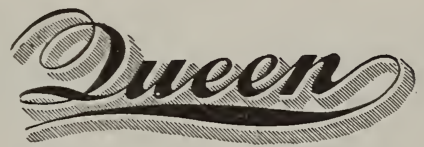

For a dependable hatcher that will operate under raried conditions with uniformly good results, the Queen Incubator is unexcelled. We can highly recommend this machine and guarantee it to do all that is claimed for it, and judging from the enviable reputation it has established for itself, it surely is making good.

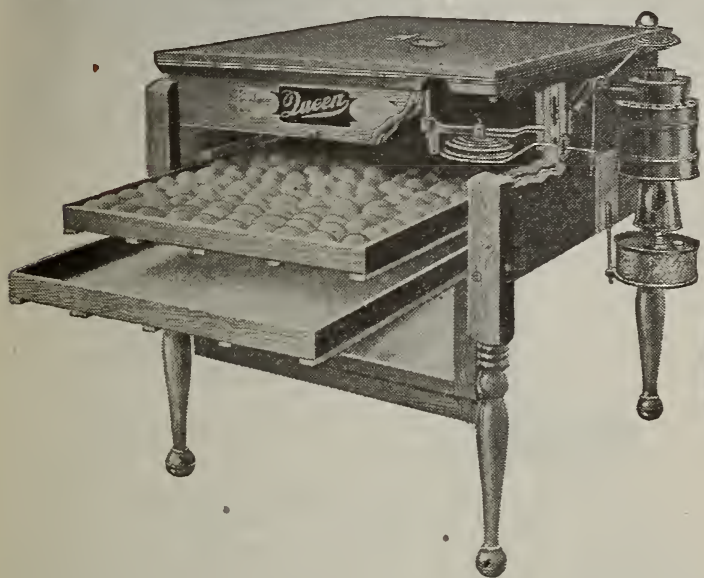

For a mother that is always on the job the Queen brooder has no equal. Made in all styles. both indoor and outdoor, lamp-heated and lamp. less, sizes 50 to $200 \mathrm{chick}$. Every brooder is guar anteed and fully equipped, ready for business when you receive it. Hatch your chicks in a Queen Incubator, raise them in a Queen Brooder, to get the most profit from your poultry yard.

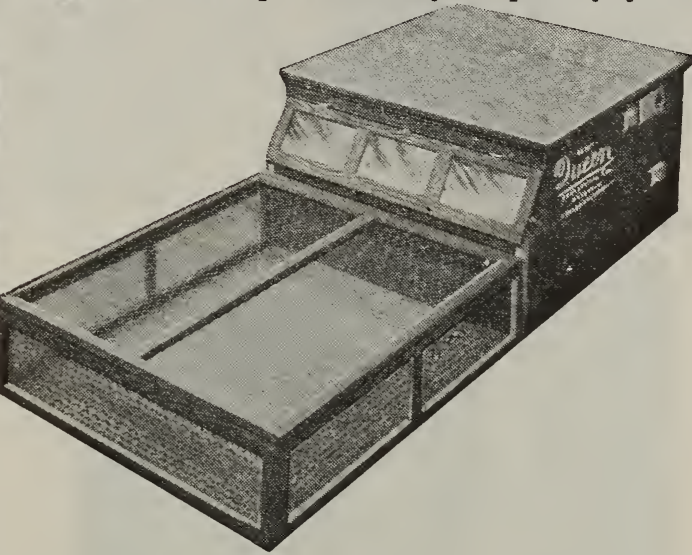

There are twenty-eight (28) reasons why the Queen excells all other makes regardless of price. Many others sell for fifty to one hundred per cent more than we ask for the Queen. The Queen is the Standard Hot-Water Incubator of the World, and so much as hot water excels hot air heating, just that much is the Queen superior to any hot air machine.

Queen construction is the best. California Redwood case, double wall, and double lined with heavy deadening felt. Double doors, inner one glass, giving full riew of egg chamber. Jacketed copper boller and radiator, lock seam joints heaviiy soldered. Galvanized steel seamless lamp bowl, heary brass burner of our own special design to meet incubating requirements. Automatic heat regulator adjusted at factory under actual incubating temperature. Long substantial legs, no stooping to turn eggs. Self-supporting egg trays and chick drawers, deep nursery to care for baby chicks when first hatched. Ventilation, automatic with adjustment for hatching time and hot weather. Adjustable metal lamp shelf, metal egg tester, funnel, special mercury incubator thermometer. Big 24-page instruction book which tells how to set up and run the Queen for big results and also gives a large amount of information useful to the chicken raiser. These are but a few of the 28 special features to be found on the Queen.

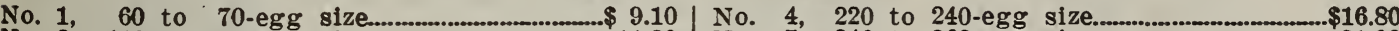

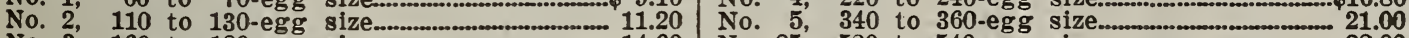

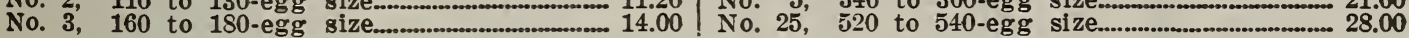

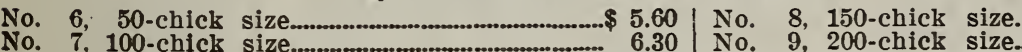
$\$ 7.00$ 7.70

QUEEN OUTDOOR LAMP-HEATED BROODERS $\$ 9.80 \mid$ No. 12,200 chick-size. $\$ 12.60$

No. 10,100 -chick size 11.20

No. 11, 150-chick size

QUEEN INDOOR LAMPLESS BROODERS

No. 26, 50-chick size $\$ 3.50 \mid$ No. 28, 100-chick size

No. 27,100 -chick size \begin{tabular}{l|ll}
3.50 & No. 28, & 100 -chick size \\
4.20 & No. 29,200 -chick size
\end{tabular} 5.60

No. 30, 100-chick size

QUEEN OUTDOOR LAMPLESS BROODER $\$ 8.40$ No. 32,200 -chick size. $\$ 11.20$

No. 31 , 150-chick size

All the above prices are F. O. B., Lincoln, Nebr.

Write for special prices with freight paid to your depot.

In both Queen Incubators and Brooders we offer high quality at low prices. Every machine is fully guaranteed.

It is not so much what the manufacturer says, or what we say about them, but it is what the users say that counts. Judged by this standard, Queen machines are worthy of the confldence of poultry raisers everywhere.

We do not have room in this catalog to illustrate and describe these perfect incubators and broders, but we have the regular Queen Poultry Guide and Catalog that we want to send to each one of our customers who raise poultry. This book tells all about QUEEN MACHINES and POULTRY SUPPLIES and how to raise chickens successfully, and it will be mailed FREE to all who ask for it. Address.

Gris wold Seed Co. General Agents, Lincoln, Nebraska. 
PLANT FOOD

Flowers are like people, their health depends

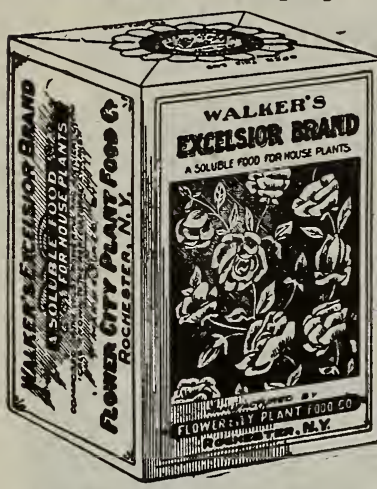

upon their food. It upon their food. It but not too rich to force $\mathrm{grow} t \mathrm{~h}$ and cause reaction. A chemically correct flower food for house plants is

Walker's Excelsior Brand

It has no odor whatever and can be used dry or dissolved in water for sprinkling. Use it and your flowers will flourish a $n$ d their $h \in a 1 t h$ will last. S m a 11 size (feeds 25 plants 6 months) 30c: lare? we (enough for a jear) 50c; poutpaid.

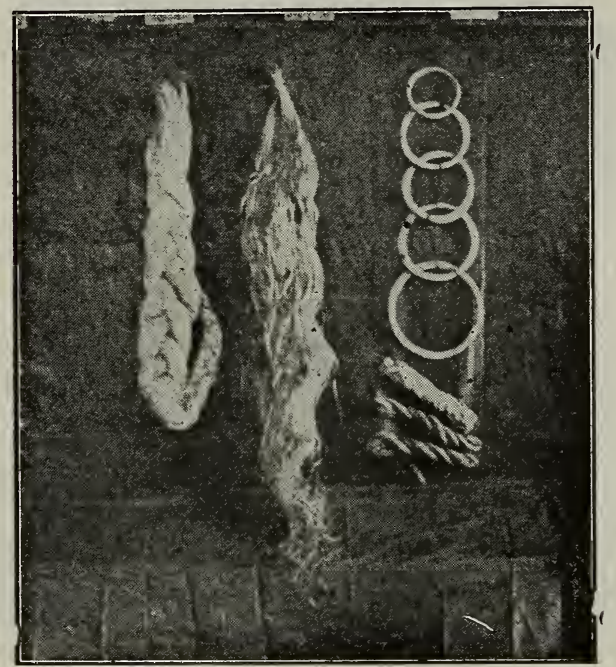

Size

No. 1 Fenes and mitset Ft. By Mail Ft. Price by Mail

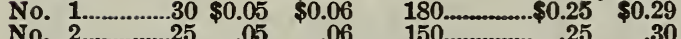

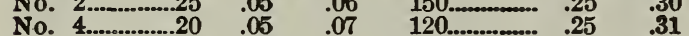

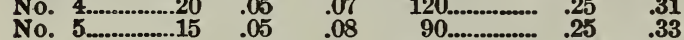

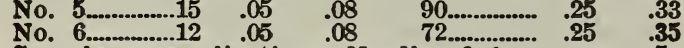
Sample on application. Needles 6 for............... Basket-making Instructions, postpaid

Colored, per skein (about 2 oz.) 10c; by mail...13c Colored, 3 skeins, 25c; by mail..........................32c Natural, per skein (about 3 oz.) $5 \mathrm{c}$; by mail.......9c Natural, per 1b. 20c; by mail...................................38c Natural, 6 pounds, $\$ 1.00$, by express at your expense.
LENOX IMPROVED SPRAYER FOR INDOOR PLANTS

Just the Thing to Save the Plants

Anyone desiring to procure an excellent hand

\section{Sent Complete}

\section{0c Postpaid}

plant sprayer to spray the leaves up on indoor plants, to keep the insects off nd otherwise

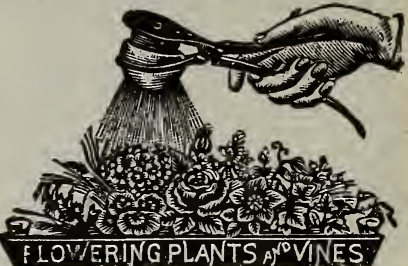

HOVI ceive one by return mail. This sprayer will spray under and over the leaves. A cake of tobacco soap to make the spray solution will be included.

\section{CONCENTRATED WABLETS}

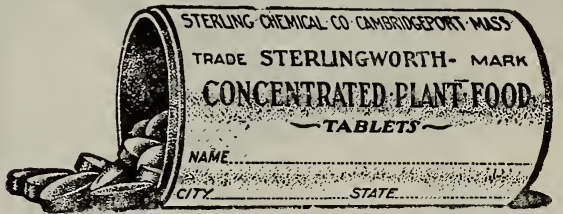

A New Scientific Concentrated Fertilizer for Potted Plants and Vegetables

Takes the place of liquid manure. Osed by dissolving in water. It starts the plants at once into hearthy and vigorous growth and makes them bloom luxuriantly. Trial size box, sufficient for 10 house plants for 3 months, $10 \mathrm{c}$, postpaid. Regular size box, sufficient for 35 plants for 3 months, 25c, postpaid.

SONG RESTORER

It restores to their natural notes, birds which have lost their song from exposure to cold or excessive moulting. The use of one box wili bring good results. Use in connection with their daily food. 25c, postpaid.

\begin{tabular}{|l|}
\hline \multicolumn{2}{|c|}{ ANIRICAN BIRD } \\
FANCIER \\
By D. J. Browne and \\
Dr. Fuller Walker. Or \\
how to breed, rear and \\
care for song and do- \\
mestic birds. All who \\
who own valuable birds, \\
or wish to do so, will \\
find the new Fancier in- \\
dispensable. Illustrated. \\
116 pages. Paper, 50c. \\
\hline
\end{tabular}

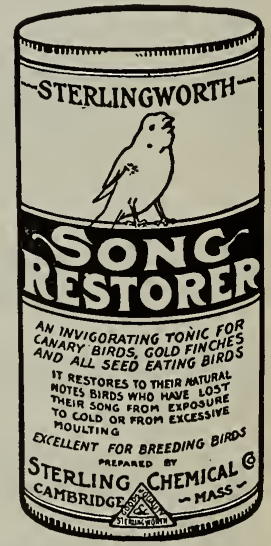

\section{BIRD SEED}

We carry a complete stock of clean, pure Bird Seed.

CANARY. (Sicily.) Superior to all other varieties. In demand by all bird dealers and others who desire best grade of seed. 1 lb., 10c; 3 lbs., 25c. By mail, 1 lb., 18c: 3 lbs., 50c.

CUTTLE BONE. Important for canaries, parrots, and all seed eating birds. 2 for $5 c$. By mail, 4c each; 45c per dozen.

HEMP, RUSSIAN. A very rich, oily seed, much liked by all birds. Should be fed sparingly as it fattens the bird and injures the song. 1 lb., 10c; 3 lbs., 25c. By mail, 1 lb., 18c; 3 ibs., $50 \mathrm{c}$.

MIXED SEED FOR CANARIES. All clean, plump seed in the proportions called for by experienced bird fanciers. This you will find more economical than package seed. 1 lb., $7 \mathrm{c} ; 4$ lbs., 25c; 17 lbs., \$1.00. By mail, 1 lb., 16c; 4 lbs., 57c.
RAPE. Very desirable to furnish variety. Many bird fanciers feed only canary and rape for regular diet of canary birds. 1 lb., 10c; 3 lbs., 25c. By mail, 1 lb., $18 \mathrm{c} ; 3$ lbs., 50c.

MAMMOTH RUSSIAN SUNFLOWER. Most important food for parrots. Very nutritious and is liked by all large seed eating birds. Can be fed freely at all times. Better order a year's supply and have it sent by freight. $1 \mathrm{lb}$., 10c: 3 lbs., 25c; 13 lbs., $\$ 1.00$; 50 lbs., $\$ 3.50100$ lbs.. $\$ 6.50$.' By mail, 1 ib., 20c; 3 lbs., 50c.

PADDA OR UNHULLED RICE. Ordinary rice of commerce in its natural state. A strengthening food for parrots, red birds, etc. 1 lb., 10c; 3 lbs., 25c; 13 lbs., \$1.00. By mail 1 lb., 20c; 3 lbs., 50 c. 


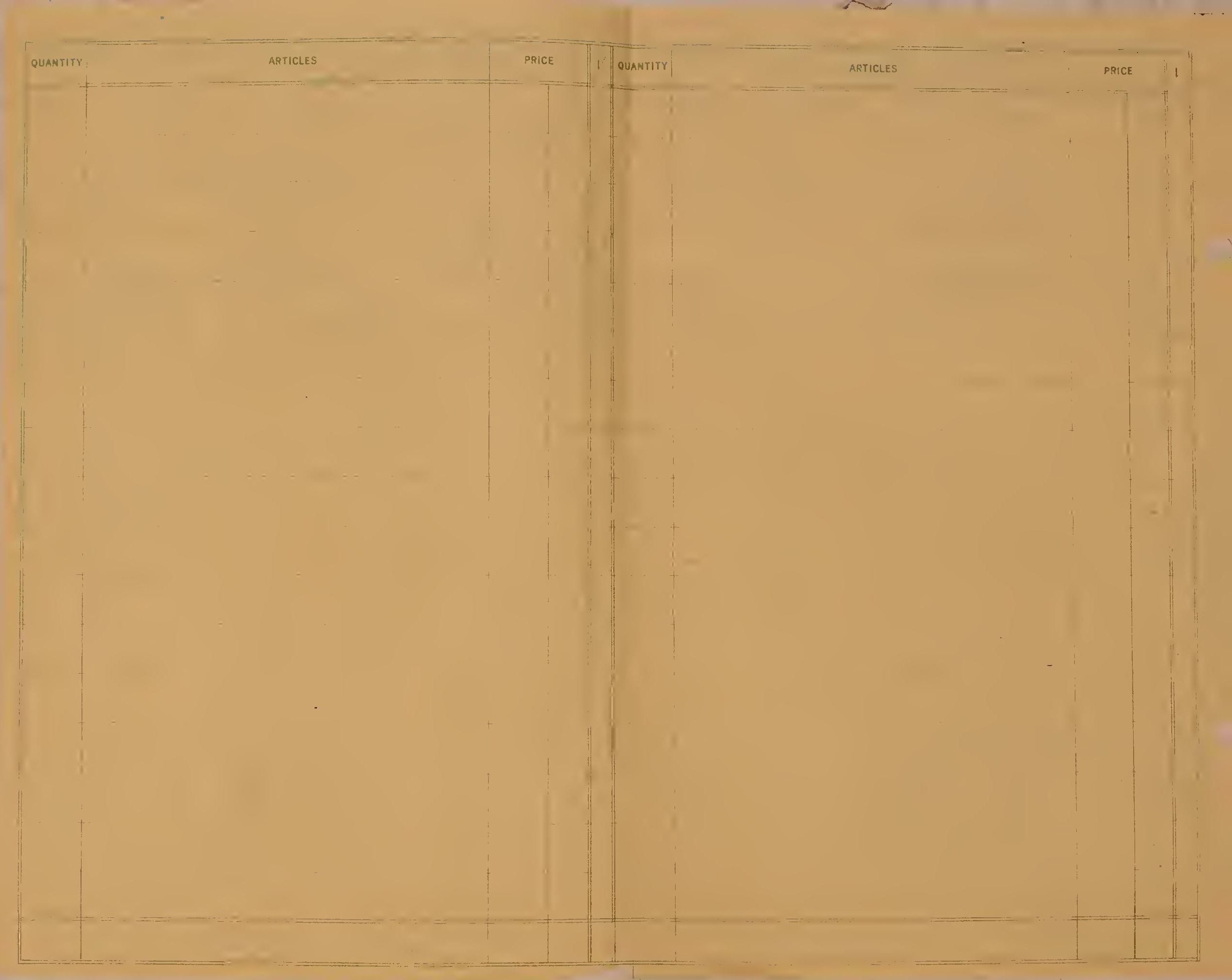


SENDER-PLEASE FILL THIS OUT.

\section{From}

P. 0.

State

\section{GRISWOLD SEED CO.,}

\section{LINCOLN,}

NEBRASKA. 
Y

$=$

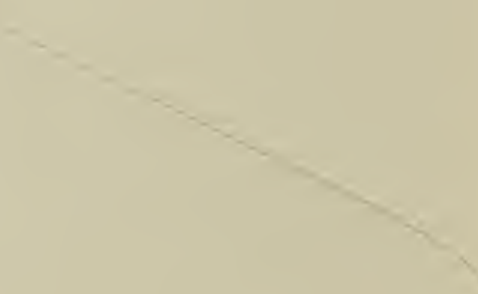




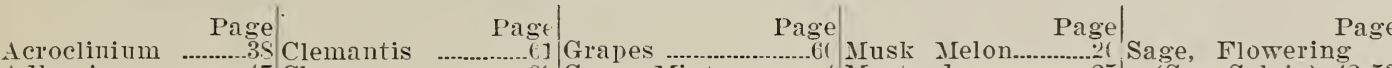

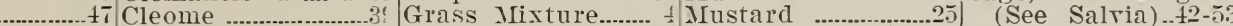

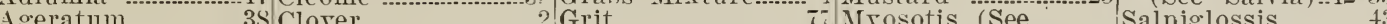

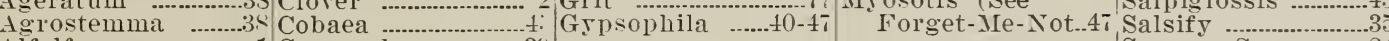

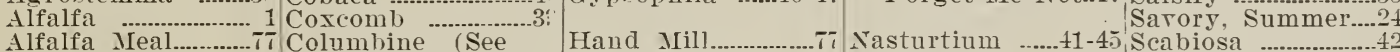
Allegheny Time Aquilegia) ....... Hand Planters...9-1: Nest Eggs... (See Adlumia)....47 Coleus ................

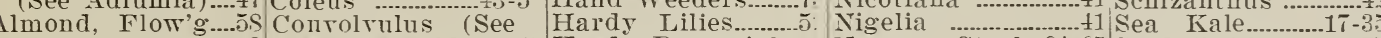
Alsike .................. 2 Morning Glors) 4: Hards Perennials. Alrssum ..................38 Coreopis ................. 47 Plants \& Sds $46-1$

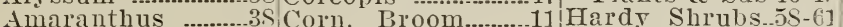
Ampelopsis .............61 Corn, Field_....... Antirrhinum ...........3S Corn, Kaffir............. ( Helianthus (See Aristolochia ..........4t Corn Sarer Beet.... of Tead to Corm Sala Aquilegia ................t Corn Planter. Asparagus ...............14 Corn Sheller Asters .....................3S Corn. Sweet

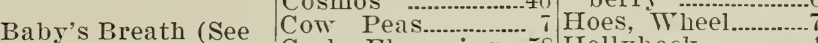

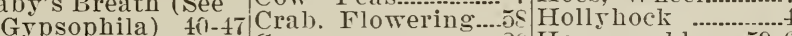

Cress (See Centaurea) ...3:) Cristal Palace

Balloon vine......... (St4 Lobelia)...... Balsan: ….................... 39 Cucumbers

Balsam Apple and Currants

Pear Currant. Flowr's.

Barberry Cuttle Bone

Barker Teeder......5 Cyclamen ........................... (See Dolichos)

Bisirley 11 Cypress Vine. Sunflower)

Heliotrope

Hemp

9 Herbs

Highbush CranHops, Japanese (See Humulus)

Horse Hoes.... Horse

\section{Onious}

Onion Sets

Orchard Grass

Osster Shells........ 7 Slu Shot Osster Plant (See Small Fruits........66-6? Salsify) ................. Smilax

Seed Sower's

Serieitire Plant 4

Selieitive Plant......t. Shasta Dais Sheller, Corn. Oxalis

Padda

Paeonies

Pansies

Smoke Tree (See
Purple Fringe)..60 Purple Fringe)
Snapdragon (See Antirrhinum)

Hotbed
Humulus

1 Hracinth Bean

Basket Materals c.o

Beans 15-16 Dahlia ................50-51 Ice Plant

Beets.................. 19-20 Daisy (See Bellis) $1^{-}$Impatiens

4 (mplemer

Bellis ...................... 47 Daisy, Shasta........4 4 Im Incubator

Rignonia ............. 6 19 Delphinium ...........47 Insecticides

Bird Seed

Deutzia

Blackberries ..........42 Digitalis

Blood . Dil .....

Blood Meal............. 7 - 7 D D olichos

Blue Grass...........3-62 2 Dolichos

Bone Cutter............... Drills ...

Boston Iry............. (1)

Boston Iry.........

Ego, Nest

(See Spirea) $59 \mathrm{Eg}$ ' Plant

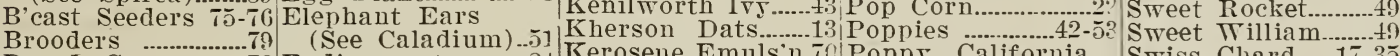

70-71 Periwinkle (See

Sorghum

Passion Flower..... S Spinach

Peanuts ....................30 Spirea ...............

Peas ................29-3i Sprayers 71-72-73-S0

Peas, Field.............. 7 Spray Mixtures....

Pencilaria ............... ô. Squash .....................

1. Pentstemon ............49 Stocks ......................43

4. Pepper's .....31 Stokesia Cranea....49

Té Peprer Plants........14 Strawberries .........69

-1 Periwinkle (See $\quad$ Sugar Beets.............1

41 Vinca)

Petunia

41-2..4. (See Kochia) ......4

Iron Age Tools....

. Ir. Bostoll.............. Summer Flower5 Iry, Engleman's....61 Pinks (See

Syringa (See

Dianthus) ......40-4s Mock Orange) ....60

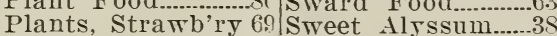

Plants, Vegetoble 14 Sweet Col'n..............?

Kaffir Corn............ ( Plumarius (See
Kale (Borecole)....24| Dianthus) Sweet Peas....................4

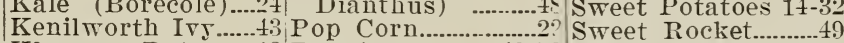

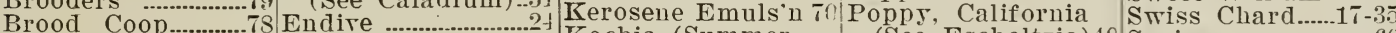

Brome Grass.......... 4 English Blue Grass 30 Kochia (Summer

Broom Corn............11 Escholtzia .............40| Cypless ..............40 Portulaca (Rose

Brussels Sprouts..16 Ererlast'g Fl'w's..40 Kohliabi ................ Mt Moss)

Buckwheat

Bug Death.................70

Burning Star

Lanceolata (See

Lanceolata (See Potato, Plants

(See Lychnis) ....49 Fall Bulbs............... Li Lantana

Butterfly Flower, Farkspur

(Schizanthus) ....42 Feeder's

$$
\text { Ferns }
$$

Cabbage ..................19 Fertilizers

Cabbage Plants....14 Fererfew

Cacalia

39) Flax

Calendula

39 Flower Pots

Caladium

51 Fly-Killer

Calf Meal.................... 66 Forget-Me-Not

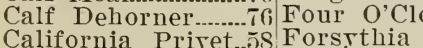

Calliopsis 39 Forglore (See

Campantiliopis

Digitalis)

Can's B'd Flower..4. Fruit, Small.......66-6

Canars Seed...........81

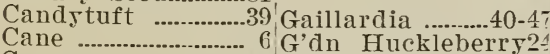

\section{1} Canna ................. 39- 0 Garden Imple-

Carnatio

\author{
$74-7$
}

Carrot -............ 20 Garlic

Castor Bean (See Geranium .........................

(Ricinus)

Cauliflower

Celeriac

Celery

Celosia
Centaurea

Chick Food..................77 Golden Feather.....

Charcoal

7 Golden Feather.

$.7 \mathrm{~s}$

Lathyrus

Larn

47 Potato, Sweet

. Poultry Sup'ls T7-

4 Pride of Rochester (See Deutzia).....

49 Lawn Rollers.

Leek

Leg Bands.

Lettuce

Lice Killer

Lilies

Lilac

Lobelia

24 Primula

62 Pumplins

Syringa

60

Lychuis

Maderia Tine

63 Purple Fringe.....

4 Pyrethrum (See Golden Feather)

Quince, Scarlet

60

Japan

Mancel Trurzel.

Iarigold Marjoram. Sweet..24
Meadow Fescue... 3 Red Top..................... 3 Virginia Creeper

13 Radishes

Rape,

Table of Weights..1?

Thyme Timoth 5 ..................

Tobacco …................

Tobacco Dust........

Tobacco Soap........

Trowels .......

Trumpet Vine.........61

Tuberoses …............

Vegetable Orster

(See Salsif $x$ ).......3.

Vegetable Plants..1t

Velvet Flower (See

Salpiglossis)

.................4 Verbena

rralf Essex 7 Vetch

1' Raspberries ............ 6 \& Vinca

41 Rattan ..................... \& Vines, Hardy...........61

Ieat Scraps

Telons IIusk of Phubar

Rhubarb

Mignonette

Ribbon Grass.

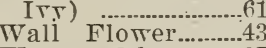

41 Ricinus

Milkin ${ }^{\text {Tubes }}$

Roup Cun

Milo Maize................

Puller..........

Weigelia ......................60

Iock Orange................ Wh

Iole Trap

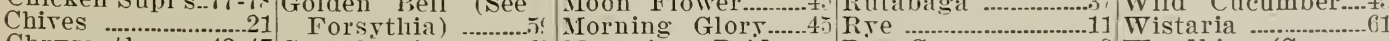

Chrysanthmum 43-47 Gooseberries ............ Mourning Bride R Te Grass................ ? Woodbine (See

Cinnamon Vine.....51 Gophergo ................

Clarkia

39 Gourds

4. Mushrooms ............2( Sage

Engleman's Ivy) 61 


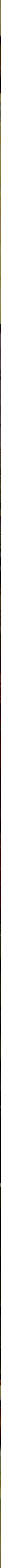

